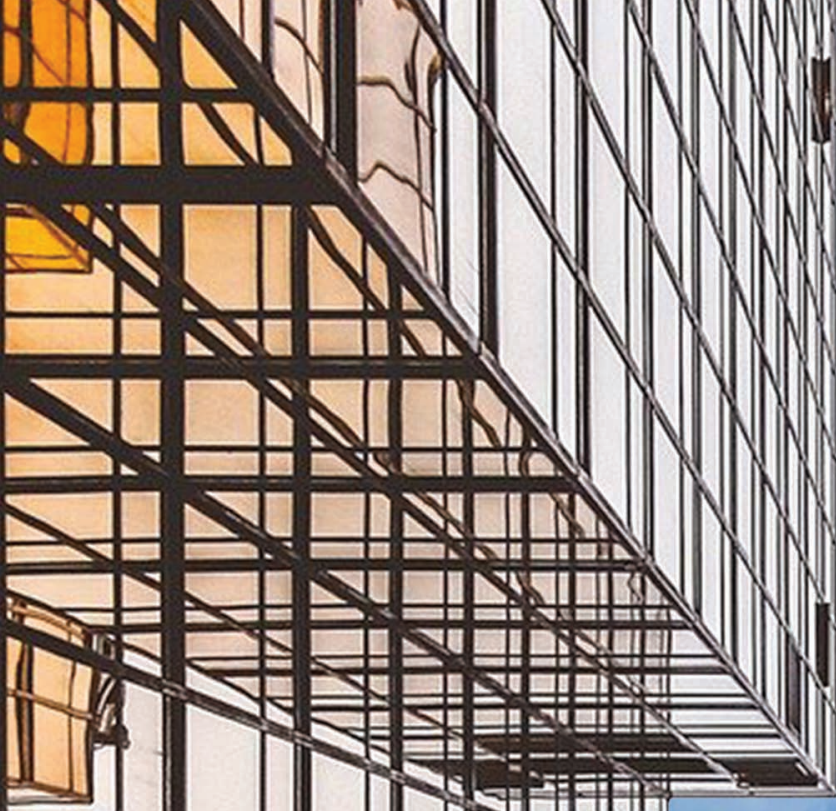

Jerneja
PROSTOR

Daniel
ZDOLŠEK

Študijsko gradivo pri predmetu KORPORACIJSKO IN KONCERNSKO
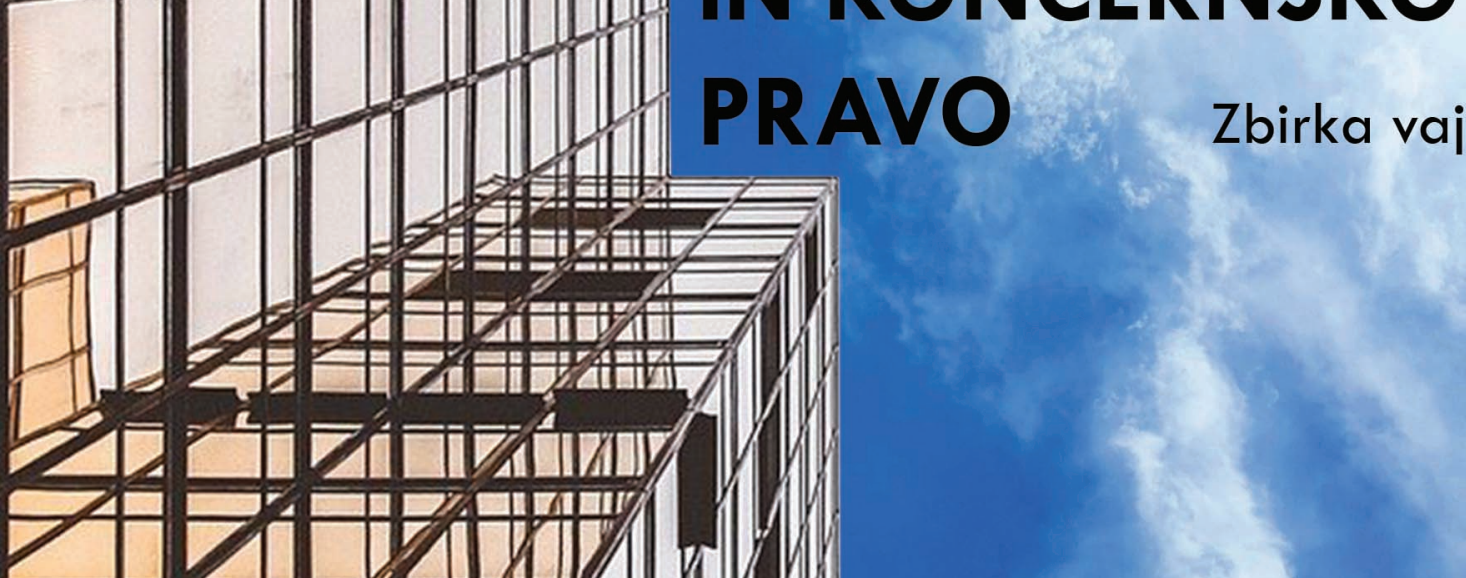

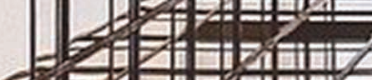

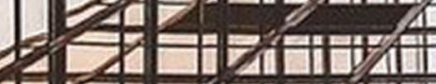

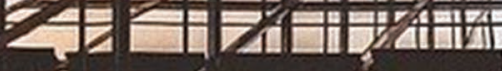

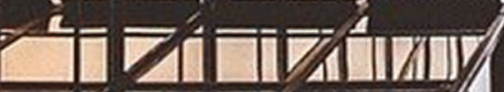

有1010

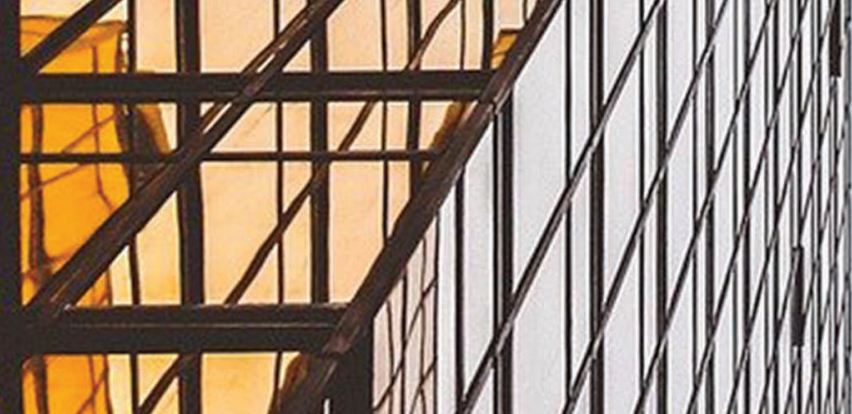


Univerza v Mariboru

Pravna fakulteta

\section{Študijsko gradivo pri predmetu Korporacijsko in koncernsko pravo}

Zbrika vaj

Avtorja

Jerneja Prostor

Daniel Zdolšek

Februar 2022 


\section{Naslov Študijsko gradivo pri predmetu Korporacijsko in koncernsko}

Title pravo

Study material for Corporate law and Law of Groups of Companies

\section{Podnaslov Zbirka vaj}

Subtitle A Collection of Exercises

Avtorja Jerneja Prostor

Authors (Univerza v Mariboru, Pravna fakulteta)

Daniel Zdolšek

(Univerza v Mariboru, Ekonomsko-poslovna fakulteta)

Recenzija Marijan Kocbek

Review (Univerza v Mariboru, Pravna fakulteta)

\section{Tehnična urednika}

Dunja Legat

Technical editors

(Univerza v Mariboru, Univerzitetna založba)

Jan Perša

(Univerza v Mariboru, Univerzitetna založba)

\section{Oblikovanje ovitka}

Cover designer

Jan Perša

(Univerza v Mariboru, Univerzitetna založba)

\section{Grafika na ovitku}

Cover graphicse

Architecture-skyscraper, 768432, Pixabay.com CC0

\section{Grafične priloge}

Graphics material

Avtorja

\section{Založnik \\ Publibed by}

Izdajatelj
Issued by

Izdaja

Edition

Vrsta publikacije

Publication type

Dostopno na

Available at

Izdano

Published

\section{E-knjiga}

https://press.um.si/index.php/ump/catalog/book/533 
To delo je objavljeno pod licenco Creative Commons Priznanje avtorstva 4.0 Mednarodna. / This work is licensed under the Creative Commons Attribution 4.0 International License.

Uporabnikom je dovoljeno tako nekomercialno kot tudi komercialno reproduciranje, distribuiranje, dajanje $\mathrm{v}$ najem, javna priobčitev in predelava avtorskega dela, pod pogojem, da navedejo avtorja izvirnega dela.

Vsa gradiva tretjih oseb so objavljena pod licenco Creative Commons, razen če to ni navedeno drugače. Če želite ponovno uporabiti gradivo tretjih oseb, ki ni zajeto v licenci Creative Commons, boste morali pridobiti dovoljenje neposredno od imetnika avtorskih pravic.

https://creativecommons.org/licenses/by/4.0/

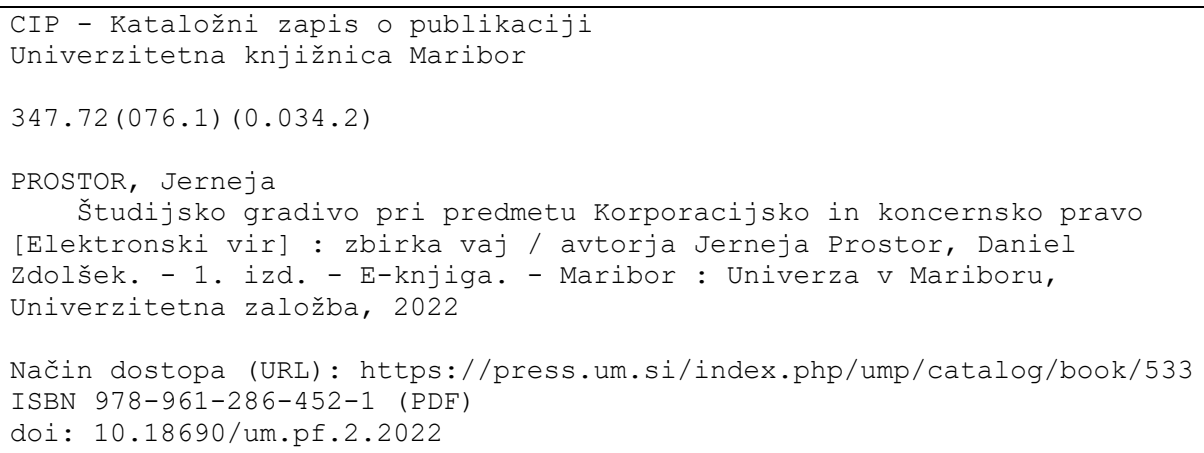

ISBN 978-961-286-452-1 (pdf)

DOI https://doi.org/10.18690/um.pf.2.2022

\section{Cena
Price}

Odgovorna oseba založnika prof. dr. Zdravko Kačič, Forpublisher rektor Univerze v Mariboru

Citiranje Prostor, J. in Zdolšek, D. (2022). Študijsko gradivo pri predmetu Attribution Korporacijsko in koncernsko pravo: zbirka vaj. Maribor: Univerzitetna založba. doi: 10.18690/um.pf.2.2022 


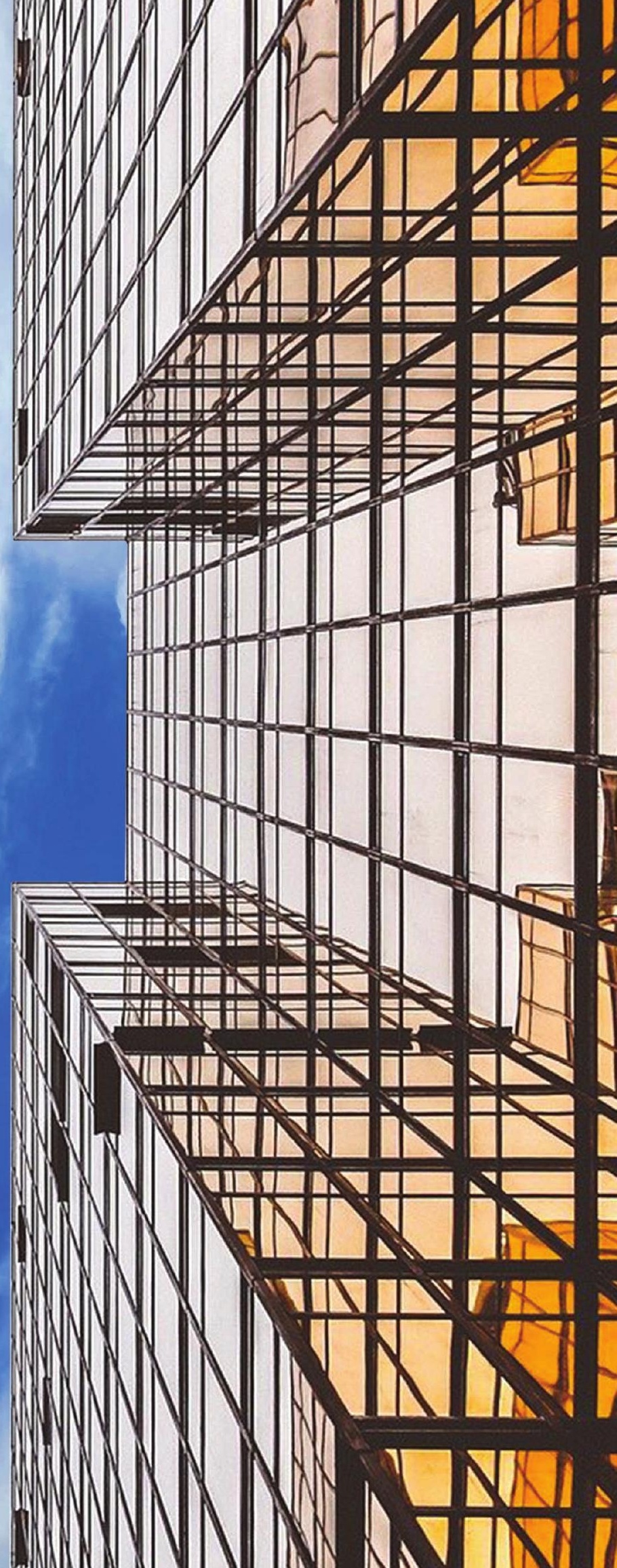


ŠTUDIJSKO GRADIVO PRI PREDMETU KORPORACIJSKO IN KONCERNSKO PRAVO: ZBIRKA VAJ

\section{Kazalo}

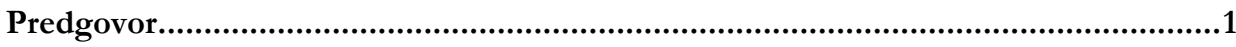

I. del: Priprava (poenostavljene) bilance stanja in izkaza poslovnega izida

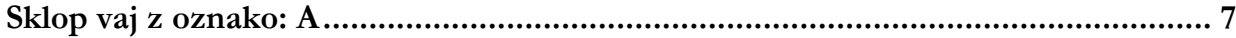

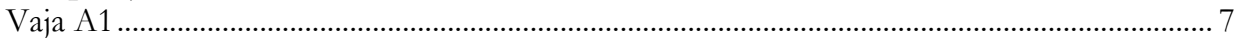

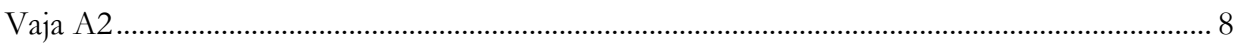

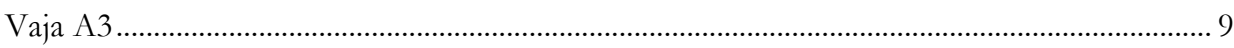

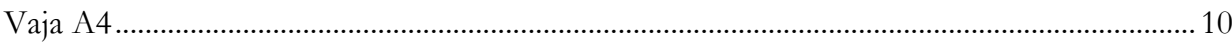

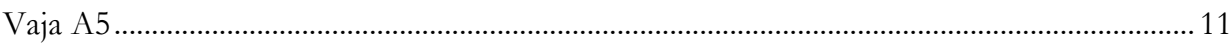

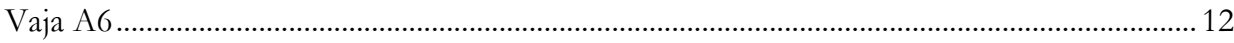

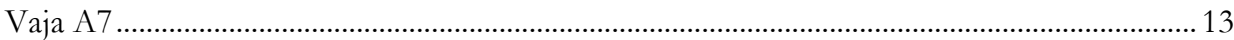

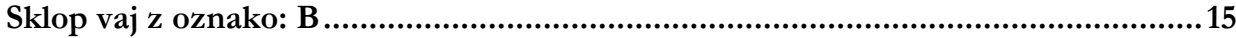

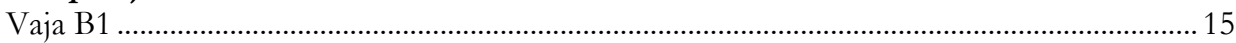

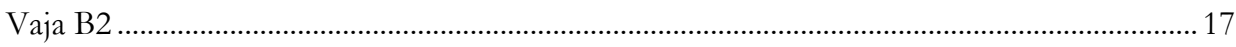

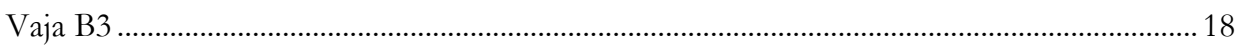

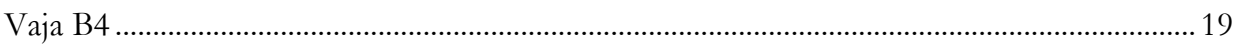

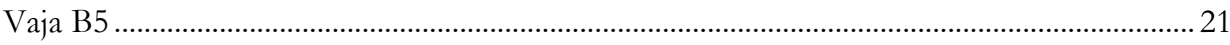

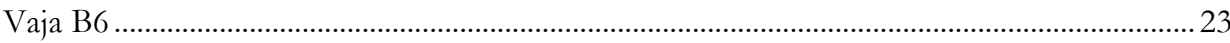

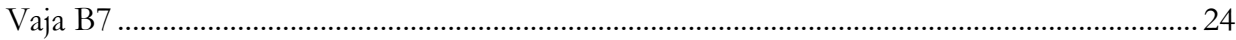

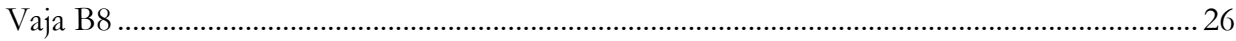

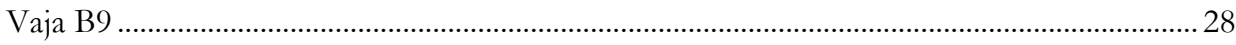

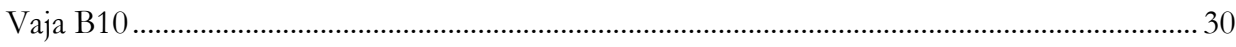

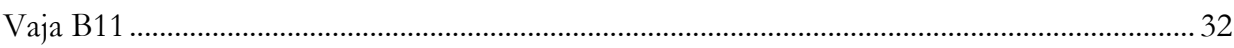

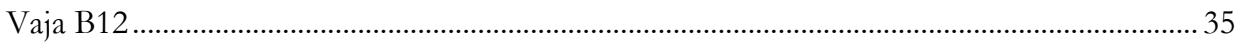

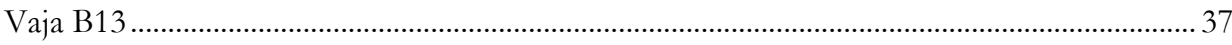

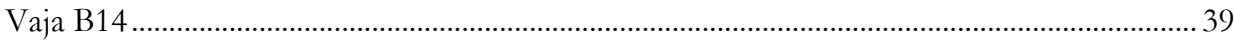

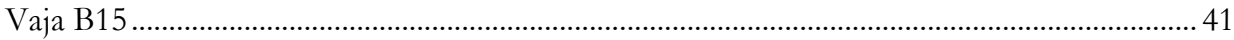

Sklop vaj z oznako: C ...............................................................................45

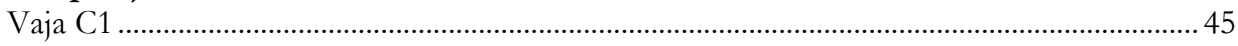

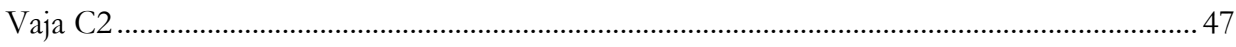




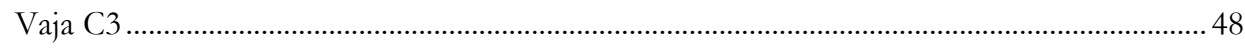

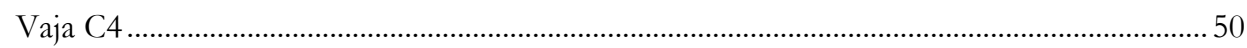

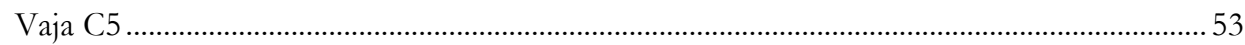

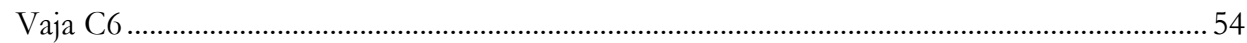

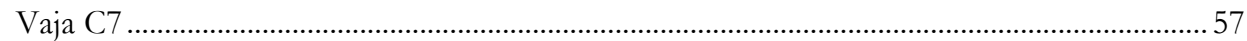

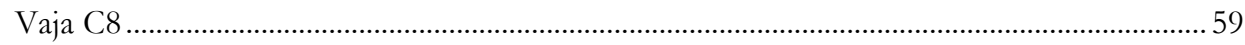

II. del: Vaje s področja (bilančnega) prava

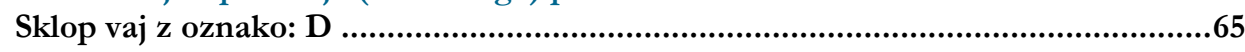

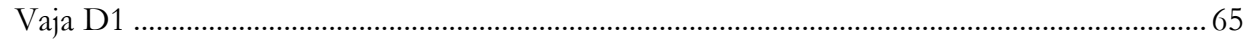

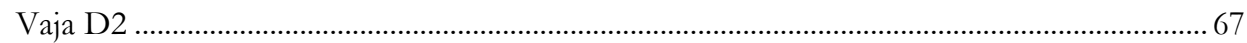

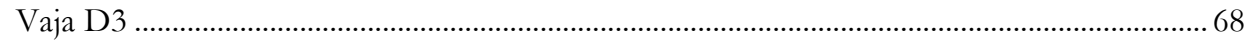

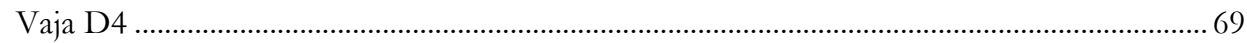

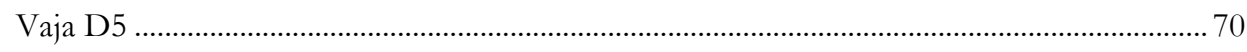

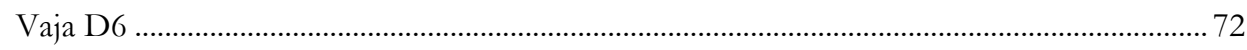

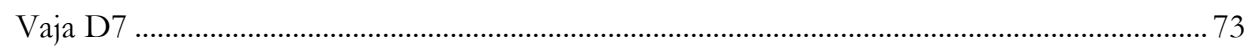

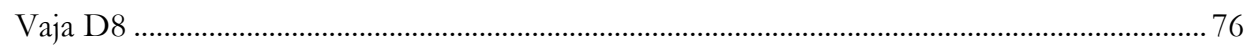

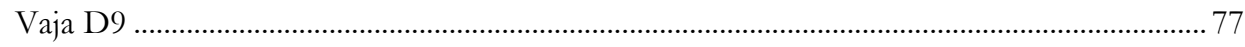

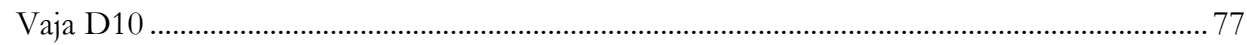

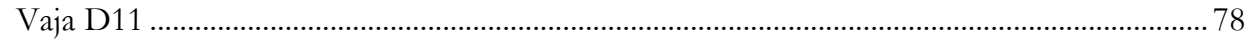

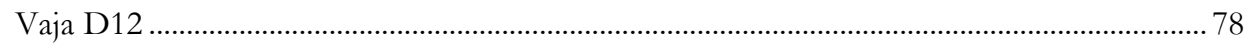

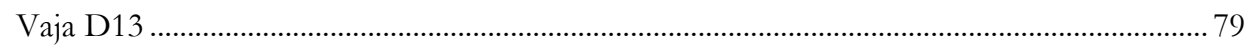

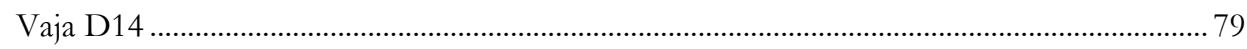

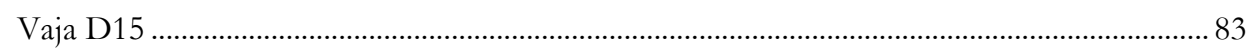

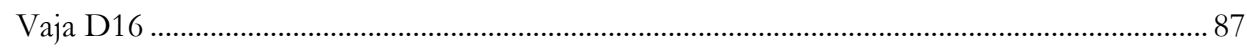

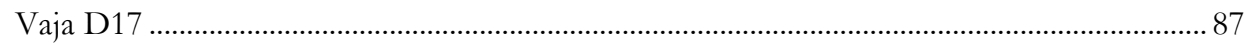

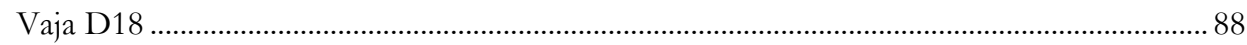

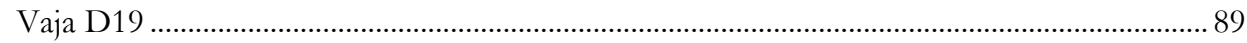

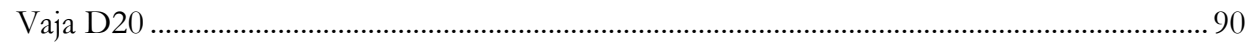

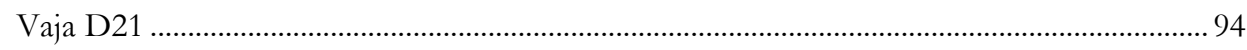

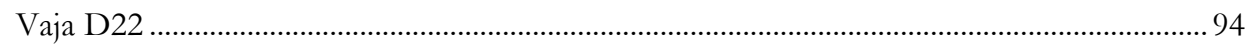

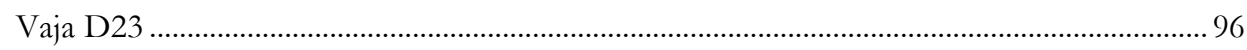

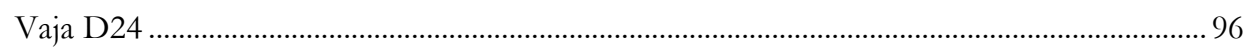

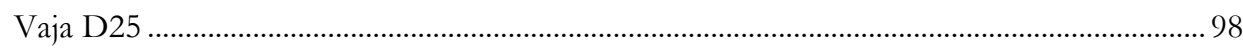

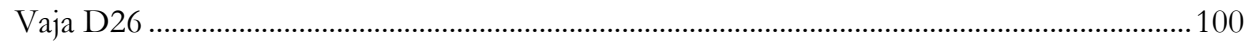




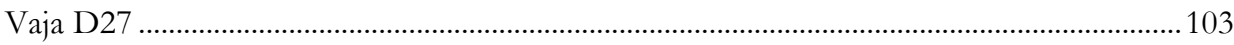

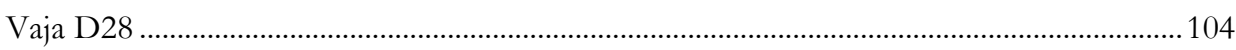

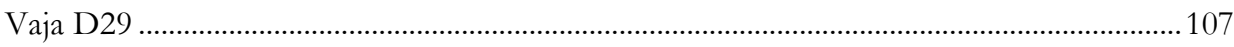

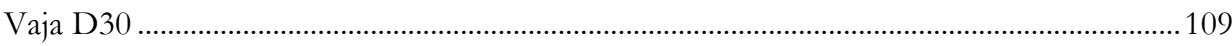

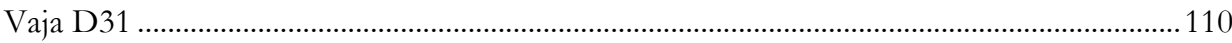

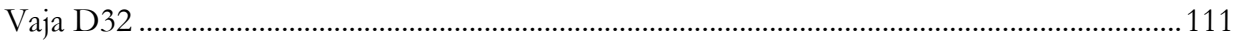

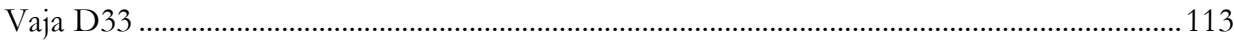

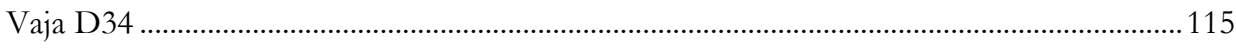

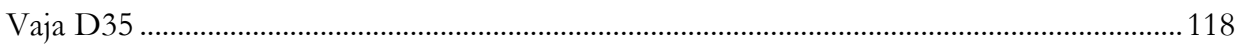

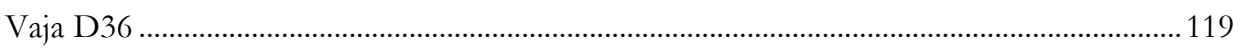

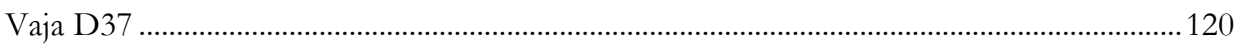

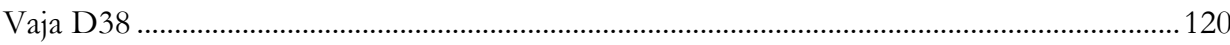

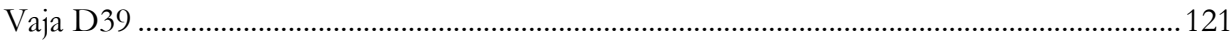

III. del: Vaje za utrjevanje znanja

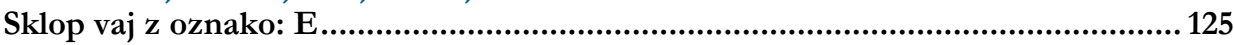

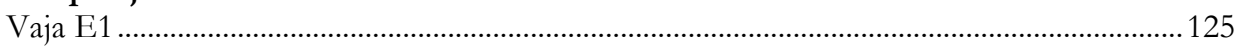

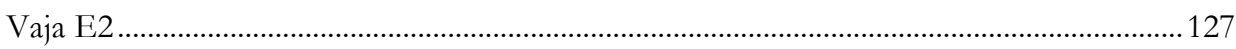

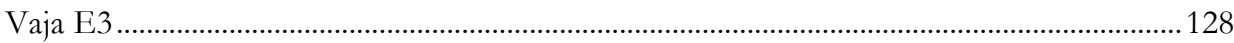

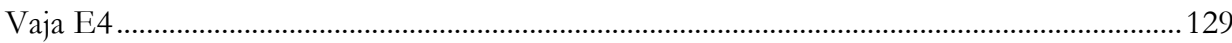

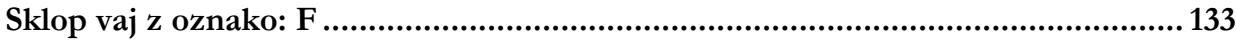

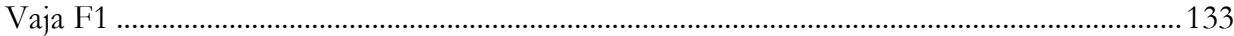

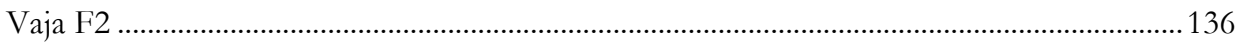

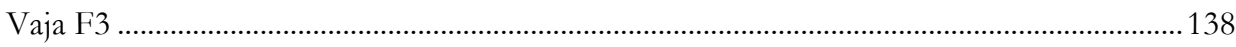

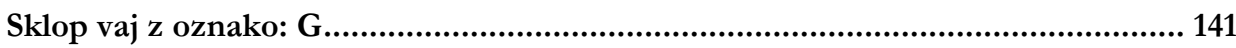

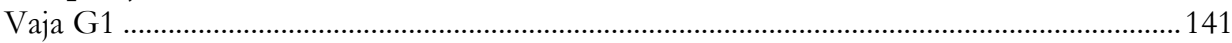

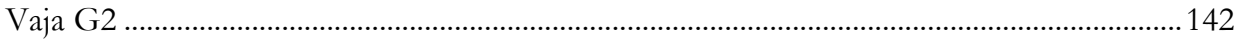

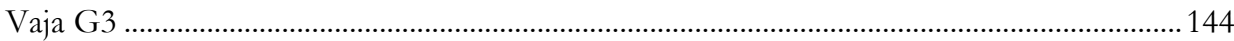

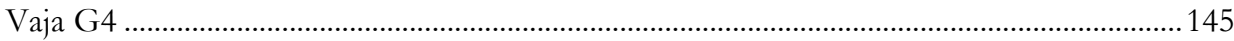

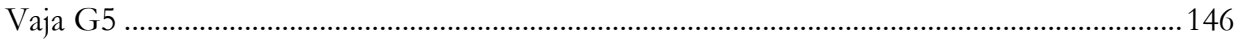

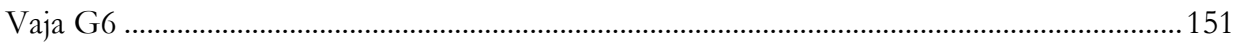

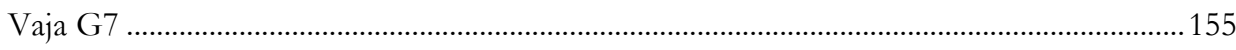

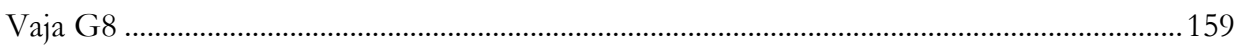

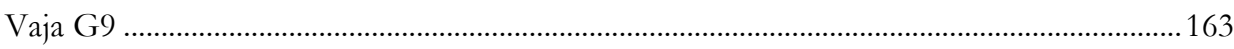

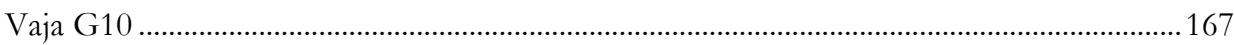




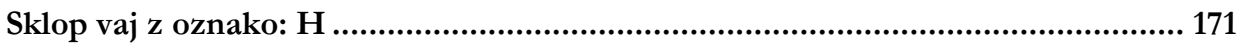

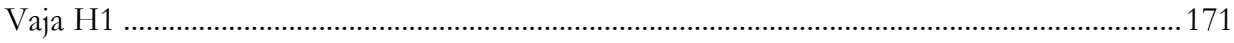

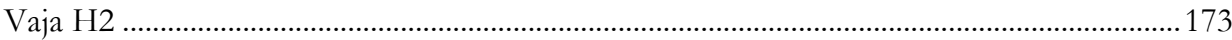

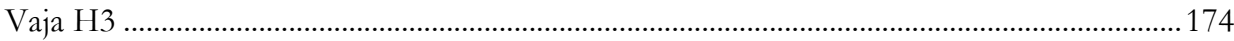

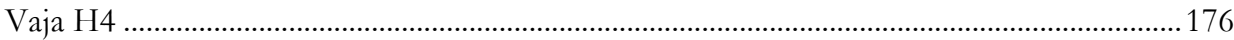

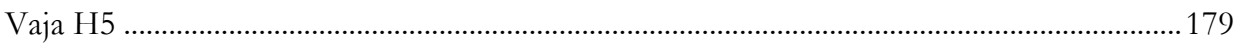

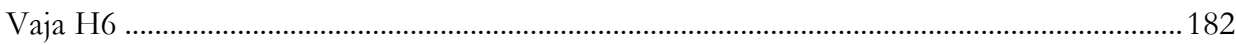

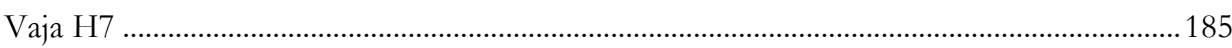

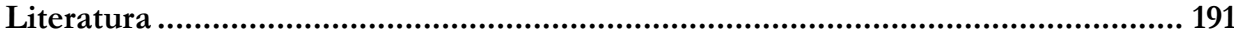




\section{Predgovor}

JERNEJA Prostor IN DANIEL ZDOLŠEK

Študijsko gradivo v obliki zbirke vaj je pripravljeno za izvedbo vaj v pedagoškem procesu pri predmetu Korporacijsko in koncernsko pravo na drugi stopnji bolonjskega študija prava na Pravni fakulteti Univerze v Mariboru. Delo sva pripravljala avtorja s področij pravnih in ekonomsko-poslovnih znanosti. Snov terja namreč dobro poznavanje zapletenih pravnih vprašanj, ki so neločljivo povezana z računovodskimi operacijami. Na Pravni fakulteti Univerze v Mariboru stremimo $\mathrm{k}$ cilju naše študente dobro pripraviti za delo pravnika $\mathrm{v}$ gospodarstvu. $\mathrm{V}$ poslovni praksi pa je še posebej zaželeno ali pri nekaterih delih celo nepogrešljivo, da zmore pravnik ne le kontrolirati letna poročila gospodarskih družb, temveč računovodje in ekonomiste tudi usmerjati, da pravilno in zakonito izpeljejo najtežje poslovne transakcije. Študijsko gradivo bo zato nujen pripomoček tistim, ki želijo kariero graditi kot gospodarski pravniki, seveda pa bo koristilo prav vsem za pripravo na izpit pri predmetu Korporacijsko in koncernsko pravo.

Študenti so na prvi stopnji študija usvojili problematiko prava družb in obravnavali osnove korporacijskega prava, zato predstavlja vsebina, ki se poučuje pri predmetu Korporacijsko in koncernsko pravo, nadgradnjo tega znanja. Na drugi stopnji se študenti še posebej poglobljeno seznanijo $\mathrm{z}$ vprašanji, ki so aktualna $\mathrm{v}$ poslovni 
praksi. A koristno je, da se snov, preden se poglobi, nekoliko ponovi in se tako olajša razumevanje obravnavane problematike. $\mathrm{S}$ tem namenom so študenti z nekaterimi sklopi vaj, zajetimi v tem gradivu, napoteni, da najprej ponovijo določene institute, ki so jih usvojili na prvi stopnji (npr. družbenikova glavna obveznost, osnovni kapital, kaducitetni postopek, rezerve, povečanje osnovnega kapitala, odsvojitev poslovnega deleža, izključitev družbenika iz d.o.o.). Sicer pa je gradivo zastavljeno tako, da I. del zajema osnove, ki jih je treba poznati za pripravo bilance stanja in izkaza poslovnega izida. Zaželeno je, da študenti ta del predelajo samostojno, preden pridejo na vaje. $\mathrm{Na}$ ta način bo delo na vajah samostojnejše in plodnejše, znanje se bo pri predmetu hitreje poglabljalo. V II. delu gradiva so nato zajete naloge, ki jih predelamo skupaj v predavalnici. Kot pojasnjeno, so $\mathrm{v}$ te vaje vpletena vprašanja, ki smo jih obravnavali že na prvi stopnji, a so nadgrajena $z$ dodatnimi vprašanji in opozorili na dileme $\mathrm{v}$ poslovni in sodni praksi. III. del gradiva je namenjen samostojnemu delu in utrjevanju znanja. Vse naloge so vsaj delno rešene ali so študentom na voljo namigi $\mathrm{k}$ rešitvam, da se jih tako spodbudi $\mathrm{k}$ delu in se jim omogoči preverjanje rešitev ter razumevanja snovi. Pri nekaterih nalogah je za pravilne rešitve nujno prebrati kakšen dodaten članek, na katerega so študenti posebej opozorjeni. Prav tako so z namigi na ustrezno sodno prakso spodbujeni, da rešitve iščejo s pomočjo domačih sodnih odločb.

Za recenzijo te zbirke vaj se najlepše zahvaljujem predavatelju, g. prof. dr. Marijanu Kocbeku. Ob tej priložnosti se zahvaljujem tudi za njegovo neprecenljivo mentorstvo, številne diskusije, dragoceno podporo in spodbudo k raziskovalnemu ter pedagoškemu delu. 



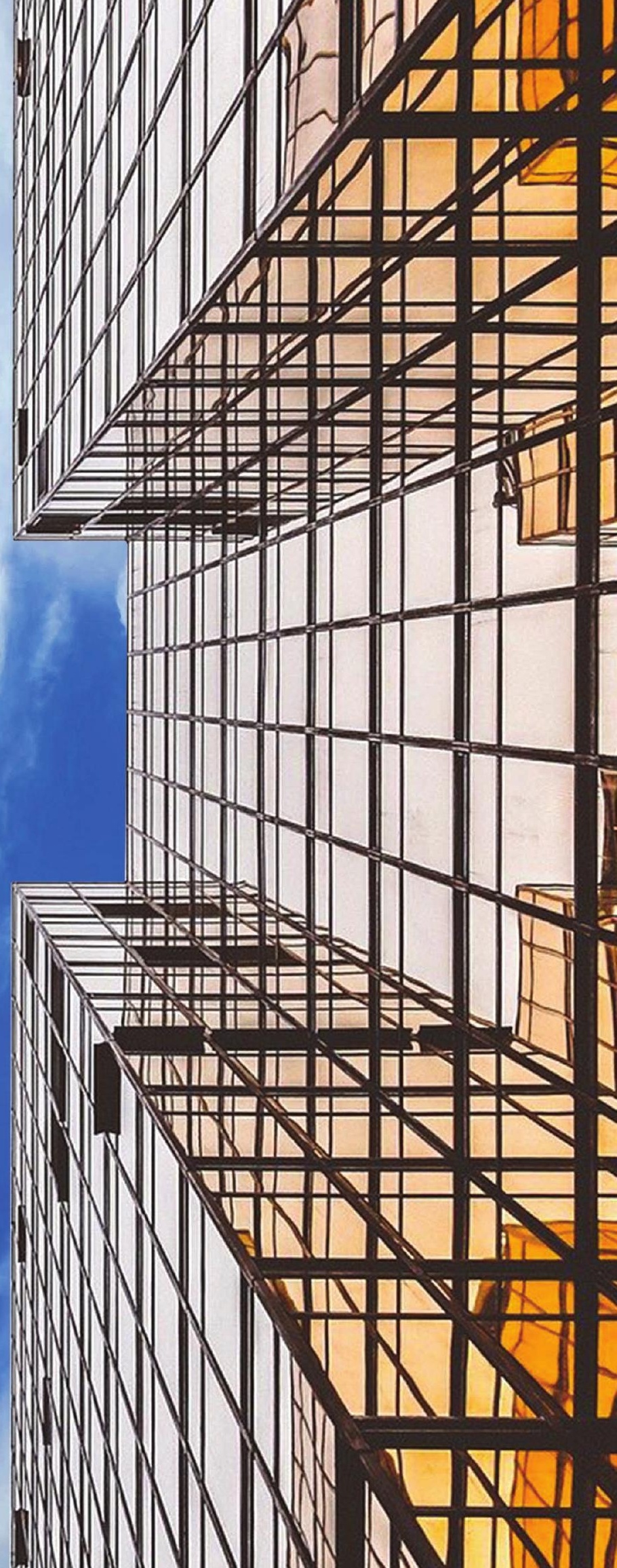


Prvi razdelek študijskega gradiva (I. del) vsebuje več različnih vaj (nalog), ki zahtevajo pripravo (poenostavljene) bilance stanje in izkaza poslovnega izida (kot dveh računovodskih irkazov). Namen tega dela gradiva je, da se tekom reševanja vaj (nalog) uporabnika/-co gradiva seznani z (nekaterimi) gospodarskimi kategorijami, s katerimi se opisuje raznovrstne poslovne dogodke in ki se jih vključuje $\mathrm{v}$ navedena računovodska izkaza. S tem se želi doseči cilje razumevanja gospodarskih kategorij, njihovega povezanega spreminjanja (pri posameznem poslovnem dogodku) in obeh računovodskih izkazov.

Prvi razdelek je predvsem namenjen samostojnemu delu. Pri tem je treba opozoriti naslednje. Pri pripravi gradiva je bilo avtorjema izhodišče, da se uporabnik/-ca gradiva, prvič srečuje z gospodarskimi kategorijami in pripravo (poenostavljenih) računovodskih izkazov. Zato je gradivo z vajami (nalogami) - tako pri pripravi vaj (nalog) in njihovi razvrstitvi oz. umestitvi - izrazito pedagoško usmerjeno. Tako se npr. težavnost nalog (vaj) stopnjuje od začetka gradiva proti koncu gradiva. Besedilo vaj (nalog) pa je zapisano čim bolj določno, zaradi česar je daljše. Glede na podano izhodišče so pri vajah tako domnevane (predpostavljene) številue poenostavitue (nekatere so zapisane, vse pa ne), ki pa jih v realnosti praviloma ni. Npr. pri reševanju vaj (nalog) se predpostavlja, da ni obveznosti obračunavanja in plačevanja raznovrstnih davkov (npr. ni davka od dohodkov pravnih oseb, ni davka na dodano vrednost itd.), ni raznovrstnih stroškov, ki se sicer $\mathrm{v}$ organizacijah/družbah pojavljajo, itd.

Sestava prvega razdelka (I. dela). Vaje so razvrščene v tri sklope. In sicer, sklop vaj

- z oznako 'A': vsebuje vaje, ki obsegajo (le) poslovne dogodke, na podlagi katerih je treba pripraviti (le) bilanco stanja, ne pa tudi izkaza poslovnega izida;

- z oznako 'B': vsebuje vaje, ki obsegajo poslovne dogodke, na podlagi katerih je treba pripraviti izkaz poslovnega izida in bilanco stanja, pri čemer pa so (običajno) poslovni dogodki takšni, da če so gospodarske kategorije vključene v izkaz poslovnega izida, se hkrati v družbi/organizaciji spreminja tudi obseg denarnih sredstev, vključenih $\mathrm{v}$ bilanco stanja; ter

- z oznako 'C': vsebuje vaje, ki obsegajo poslovne dogodke, na podlagi katerih je treba pripraviti izkaz poslovnega izida in bilanco stanja, pri čemer pa so poslovni dogodki raznovrstni (torej ne nujno takšni, da če so gospodarske kategorije vključene v izkaz poslovnega izida, se hkrati v družbi/organizaciji spreminja tudi 
obseg denarnih sredstev, temveč se lahko spreminja tudi obseg nedenarnih sredstev oz. obveznosti do virov sredstev, vključenih v bilanco stanja).

Ker je študijsko gradivo z nalogami (vajami) (za)mišljeno kot študijski pripomoček, so v gradivu pri več nalogah (vajah) podani tudi namigi oz. obrazložitve v zvezi z vsebino posamezne vaje (naloge) ter pri t. im. računskih vajah (nalogah) tudi rešitve leteh. S slednjim je omogočeno uporabniku/-ci gradiva, da lahko (samo)preveri pravilnost svojega reševanja oz. razmišljanja. 


\section{SKLOP VAJ Z OZNAKO: A}

\section{Vaja A1}

Osebi AA in BB sta na začetku leta ustanovili A1 d.o.o. z 10.000 EUR osnovnega kapitala. Obe sta zagotovili 5.000 EUR denarnega vložka in takoj ob ustanovitvi tudi vplačali denarna sredstva v celoti na transakcijski račun novoustanovljene družbe.

\section{Naloga in vprašanja (z. navodili):}

- Izdelajte poenostavljeno shemo bilance stanja družbe A1 d.o.o. na začetku leta.

- Katera sredstva (premoženje) in obveznosti (do virov sredstev) ima družba? Koliko?

- Kolikšna je knjigovodska vrednost kapitala družbe?

- Kolikšna je knjigovodska vrednost poslovnega deleža vsakega družbenika?

- Kolikšno je razmerje med družbenikoma v družbi?

(Opomba: prikařite izračune in zapisite odgovore.)

\section{Vsebina / smoter naloge je usvojiti naslednje pojme in problematiko:}

- Bilanca stanja kot računovodski izkaz (»bilančna vsota«, bruto premoženje).

- Sredstva kot gospodarska kategorija (GK); knjigovodska vrednost sredstev.

- Obveznosti kot GK (lastni viri + tuji viri).

- $\quad$ Kapital $=$ razlika med sredstvi in dolgovi; neto premoženje . 
- $\quad$ Enakost med sredstvi in obv. $\rightarrow$ vedno enako, pred in po poslovnih dogodkih.

\section{Rešitev}

\begin{tabular}{|c|c|c|c|}
\hline \multirow{4}{*}{ Denarna sredstva (na TR) } & SREDSTVA & OBV.DO & \multirow[b]{3}{*}{ Osnovni kapital (vpoklican) } \\
\hline & & VIROV SRED. & \\
\hline & 10.000 & 10.000 & \\
\hline & & & $\begin{array}{ll}5.000 & \text { Družbenik. } A A \\
5.000 & \text { Družbenike } B B\end{array}$ \\
\hline SKUPAJ SRED. >> & 10.000 & 10.000 & $<<$ SKUPAJ OBV. \\
\hline
\end{tabular}

Vaja A2

Osebi AA in BB sta na začetku leta ustanovili družbo A2 d.o.o. z 10.000 EUR osnovnega kapitala. Vsaka od njiju ima $50 \%$ poslovni delež v tej družbi. Oseba AA je zagotovila poslovni prostor kot stvarni vložek v višini 5.000 EUR, oseba BB pa je zagotovila 5.000 EUR denarnega vložka. Oseba BB je takoj ob ustanovitvi tudi vplačala celotni denarni vložek na transakcijski račun novoustanovljene družbe.

Naloga in vprašanja (z. navodili):

- Izdelajte poenostavljeno shemo bilance stanja družbe A2 d.o.o. na začetku leta.

- Katera sredstva (premoženje) in obveznosti (do virov sredstev) ima družba? Koliko?

- Kolikšna je knjigovodska vrednost kapitala družbe?

- Kolikšna je knjigovodska vrednost poslovnega deleža vsakega družbenika?

- Kolikšno je razmerje med družbenikoma v družbi?

(Opomba: prikažite izračune in zapišite odgovore.)

Vsebina / smoter naloge je usvojiti naslednje pojme in problematiko:

- Vrste sredstev: denarna in nedenarna sredstva.

- Lastniško financiranje. 


\section{Rešitev}

\begin{tabular}{|c|c|c|c|}
\hline \multirow{4}{*}{$\begin{array}{r}\text { Nepremičnina (posl. prostor) } \\
\text { Denarna sredstva (na TR) }\end{array}$} & SREDSTVA & OBV.DO & \multirow[b]{3}{*}{ Osnovni kapital (vpoklican) } \\
\hline & & VIROV SRED. & \\
\hline & 5.000 & 10.000 & \\
\hline & 5.000 & & $\begin{array}{ll}5.000 & \text { Druǧbenik } A A \\
5.000 & \text { Druǧbenik } B B\end{array}$ \\
\hline SKUPAJ SRED. >> & 10.000 & 10.000 & $<$ SKUPAJ OBV. \\
\hline
\end{tabular}

\section{Vaja A3}

Osebi AA in BB se odločita, da bo imela družba A3 d.o.o., katere družbenika bosta, 10.000 EUR osnovnega kapitala. Oseba AA bo imela $60 \%$ poslovni delež v tej družbi in oseba BB 40 \% poslovni delež. Oseba AA je zagotovila stvarni vložek v višini 6.000 EUR, oseba BB pa je zagotovila 4.000 EUR denarnega vložka. Oseba BB je takoj ob ustanovitvi tudi vplačala celotni denarni vložek na transakcijski račun novoustanovljene družbe.

Družba takoj po ustanovitvi najame 4.000 EUR posojila pri (nepovezani) družbi POSOJA d.o.o. Posojilodajalec tudi nakaže posojilo družbi na njen transakcijski račun. (Opomba: v trenutku najema posojila ni nobenih obresti, ki bi jih moral poravnati posojilojemalec. Stroškov najema posojila ni.)

\section{Naloga in vprašanja (z. navodili):}

- Izdelajte poenostavljeno shemo bilance stanja družbe A3 d.o.o. po dogodku najema in nakazila posojila družbi.

- Katera sredstva (premoženje) in obveznosti (do virov sredstev) ima družba? Koliko?

- Kolikšna je knjigovodska vrednost (osnovnega) kapitala družbe?

- Kolikšna je knjigovodska vrednost poslovnega deleža vsakega družbenika?

- Kolikšno je razmerje med družbenikoma v družbi?

- Če bi družbo po dogodku najema in nakazila posojila družbi likvidirali, kolikšen bi bil obseg sredstev (premoženja), razpoložljivih(ega) upnikom družbe?

(Opomba: prikařite izračune in zapišite odgovore.) 


\section{Vsebina / smoter naloge je usvojiti naslednje pojme in problematiko:}

- Vrste obv. $\rightarrow$ Tuji viri. dolžniško financiranje / lastni viri.

\section{Rešitev}

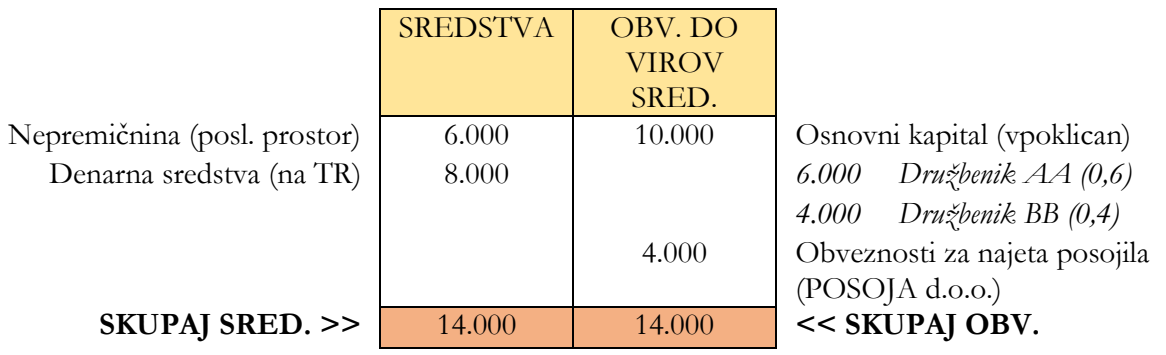

\section{Vaja A4}

Osebi AA in BB sta na začetku leta ustanovili družbo A4 d.o.o. z 10.000 EUR osnovnega kapitala. Oseba AA bo imela $70 \%$ poslovni delež v tej družbi in oseba BB $30 \%$ poslovni delež. Oseba AA je zagotovila poslovni prostor kot stvarni vložek v višini 7.000 EUR, oseba BB pa je zagotovila 3.000 EUR denarnega vložka. Oseba BB je takoj ob ustanovitvi tudi vplačala celotni denarni vložek na transakcijski račun novoustanovljene družbe.

V družbi A4 d.o.o. se tekom leta zgodi naslednji poslovni dogodek:

- Poslovodstvo družbe in oseba AA se dogovorita, da družba odproda osebi AA poslovni prostor v višini 7.000 EUR (ki je vrednost enaka vrednosti stvarnega vložka družbenice, osebe AA). Na podlagi sklenjene pogodbe se opravi prenos lastništva poslovnega prostora osebi AA, oseba AA pa hkrati nakaže denarna sredstva na transakcijski račun družbe. (Opomba: stroškov in davščin v zvezi s prenosom oz. prodajo poslovnega prostora ni.)

\section{Naloga in vprašanja (z. navodili):}

- Izdelajte poenostavljeno shemo bilance stanja družbe A4 d.o.o. na koncu leta.

- Katera sredstva (premoženje) in obveznosti (do virov sredstev) ima družba? Koliko?

- Kolikšna je knjigovodska vrednost (osnovnega) kapitala družbe? 
- Kolikšna je knjigovodska vrednost poslovnega deleža vsakega družbenika?

- Kolikšno je razmerje med družbenikoma v družbi?

- Če bi družbo po dogodku prenosa poslovnega prostora k osebi AA likvidirali, kolikšen bi bil obseg sredstev (premoženja), razpoložljivih(ega) upnikom družbe?

(Opomba: prikažite iæračune in zapisite odgovore.)

\section{Rešitev}

\begin{tabular}{|c|c|c|c|}
\hline \multirow{3}{*}{ Denarna sredstva (na TR) } & SREDSTVA & OBV. DO VIROV & \multirow{4}{*}{$\begin{array}{l}\text { Osnovni kapital (vpoklican) } \\
7.000 \text { Družbenik. } A A(0,7) \\
3.000 \text { Družbenik. } B B(0,3) \\
<<\text { SKUPAI OBV }\end{array}$} \\
\hline & 10.000 & 10.000 & \\
\hline & & & \\
\hline SKUPAJ SRED. >> & 10.000 & 10.000 & \\
\hline
\end{tabular}

Vaja A5

Osebi AA in BB sta se odločili, da bo imela družba A5 d.o.o., katere družbenika bosta, 20.000 EUR osnovnega kapitala. Oseba AA bo imela $75 \%$ poslovni delež v tej družbi in oseba BB $25 \%$ poslovni delež. Osebi AA in BB sta se dogovorili in zagotovili denarni vložek. Osebi AA in BB sta takoj ob ustanovitvi tudi vplačali celotni denarni vložek na transakcijski račun novoustanovljene družbe.

V družbi A5 d.o.o. se tekom leta zgodita naslednja poslovna dogodka:

- Družba takoj po njeni ustanovitvi najame 5.000 EUR posojila pri (nepovezani) družbi POSOJA d.o.o. Posojilodajalec tudi nakaže posojilo družbi na njen transakcijski račun. (Opomba: v trenutku najema posojila ni nobenih obresti, ki bi jih moral poravnati posojilojemalec. Stroškov najema posojila ni.)

- Pred koncem poslovnega leta je poslovodstvo družbe na podlagi opravljene analize (ob upoštevanju vseh okoliščin) sprejelo odločitev, da bo posojilo do posojilodajalca POSOJA d.o.o. poplačalo takoj. To je napravila družba tako, da je najela novo posojilo pri posojilodajalcu banki BANKA d. d. v enakem znesku. Novi posojilodajalec BANKA d. d. nakaže posojilo družbi na njen transakcijski račun. Družba predhodnemu posojilodajalcu družbi POSOJA d.o.o. nakaže denarni znesek glavnice predhodnega posojila na njen transakcijski račun. 
(Opomba: $\mathrm{v}$ trenutku najema posojila ni nobenih obresti, ki bi jih moral poravnati posojilojemalec. Stroškov v zvezi s pridobitvijo, obravnavo in odplačilom posojil ni.)

\section{Naloga in vprašanja (z navodili):}

- Izdelajte poenostavljeno shemo bilance stanja družbe A5 d.o.o. na koncu leta.

- Katera sredstva (premoženje) in obveznosti (do virov sredstev) ima družba? Koliko?

- Kolikšna je knjigovodska vrednost (osnovnega) kapitala družbe?

- Kolikšna je knjigovodska vrednost poslovnega deleža vsakega družbenika?

- Kolikšno je razmerje med družbenikoma v družbi?

- Če bi družbo po dogodku odplačila posojila družbi POSOJA d.o.o. likvidirali, kolikšen bi bil obseg sredstev (premoženja), razpoložljivih(ega) upnikom družbe?

(Opomba: prikažite işračune in zapišite odgovore.)

\section{Rešitev}

\begin{tabular}{|c|c|c|c|}
\hline \multirow{4}{*}{$\begin{array}{r}\text { Denarna sredstva } \\
\text { (na TR) }\end{array}$} & SREDSTVA & $\begin{array}{c}\text { OBV. DO } \\
\text { VIROV SRED. }\end{array}$ & \multirow[b]{2}{*}{ Osnovni kapital (vpoklican) } \\
\hline & 25.000 & 20.000 & \\
\hline & & & 15.000 Drušbenik. $A A(0,75)$ \\
\hline & & 5.000 & $\begin{array}{l}\text { Obveznosti za najeta posojila } \\
\text { (BANKA d.d.) }\end{array}$ \\
\hline SKUPAJ SRED. >> & 25.000 & 25.000 & $<<$ SKUPAJ OBV. \\
\hline
\end{tabular}

Vaja A6

Osebi AA in BB se odločita, da bo imela družba A6 d.o.o., katere družbenika bosta, 100.000 EUR osnovnega kapitala. Oseba AA bo imela $60 \%$ poslovni delež v tej družbi in oseba BB $40 \%$ poslovni delež. Osebi AA in BB sta dogovorili in zagotovili denarni vložek. Osebi AA in BB sta takoj ob ustanovitvi tudi vplačali celotni denarni vložek na transakcijski račun novoustanovljene družbe.

V družbi A6 d.o.o. se tekom leta zgodi naslednji poslovni dogodek: 
- Takoj na začetku leta (po ustanovitvi družbe) sta družbenika na skupščini družbe sklenila, da se osnovni kapital zmanjša za polovico. Poslovodstvo družbe je ta sklep ustrezno objavilo.

V družbi A6 d.o.o. se po koncu poslovnega leta zgodi naslednji dogodek:

- Po koncu poslovnega leta se zmanjšanje osnovnega kapitala družbe vpiše v register. Družba je takoj po vpisu tudi izplačala denarna sredstva v ustreznem razmerju na transakcijska računa družbenikov.

\section{Naloga in vprašanja (z.navodili):}

- Izdelajte poenostavljeno shemo bilance stanja družbe A6 d.o.o. po dogodku izplačila denarnih sredstev zaradi zmanjšanja osnovnega kapitala družbe.

- Katera sredstva (premoženje) in obveznosti (do virov sredstev) ima družba? Koliko?

- Kolikšna je knjigovodska vrednost (osnovnega) kapitala družbe?

- Kolikšna je knjigovodska vrednost poslovnega deleža vsakega družbenika?

- Kolikšno je razmerje med družbenikoma v družbi?

(Opomba: prikařite iz̧račune in zapisite odgovore.)

\section{Rešitev}

\begin{tabular}{|c|c|c|c|}
\hline \multirow{3}{*}{ Denarna sredstva (na TR) } & SREDSTVA & OBV. DO & \multirow[b]{2}{*}{ Osnovni kapital (vpoklican) } \\
\hline & 50.000 & 50.000 & \\
\hline & & & $\begin{array}{ll}30.000 & \text { Družbenik. } A A(0,6) \\
20.000 & \text { Družbenik. } B B(0,4)\end{array}$ \\
\hline SKUPAJ SRED. >> & 50.000 & 50.000 & $<<$ SKUPAJ OBV. \\
\hline
\end{tabular}

\section{Vaja A7}

Osebi AA in BB sta na začetku leta ustanovili družbo A7 d.o.o. z 20.000 EUR osnovnega kapitala. Vsaka od njiju ima 50 \% poslovni delež v tej družbi. Oseba AA je zagotovila poslovni prostor kot stvarni vložek v višini $10.000 \mathrm{EUR}$, oseba BB pa je zagotovila 10.000 EUR denarnega vložka. Oseba BB je takoj ob ustanovitvi tudi vplačala 8.000 EUR denarnega vložka na transakcijski račun novoustanovljene družbe. 
Naloga in vprašanja (žnavodili):

- Izdelajte poenostavljeno shemo bilance stanja družbe A7 d.o.o. na začetku leta.

- Katera sredstva (premoženje) in obveznosti (do virov sredstev) ima družba? Koliko?

- Kolikšna je knjigovodska vrednost kapitala družbe?

- Kolikšna je knjigovodska vrednost poslovnega deleža vsakega družbenika?

- Kolikšno je razmerje med družbenikoma v družbi?

- Če bi družbo po dogodku vplačila le 8.000 EUR denarnega vložka likvidirali, kolikšen bi bil obseg sredstev (premoženja), razpoložljivih(ega) upnikom družbe?

(Opomba: prikažite ižračune in zapišite odgovore.)

\section{Rešitev}

\begin{tabular}{|c|c|c|c|}
\hline \multirow{3}{*}{$\begin{array}{r}\text { Nepremičnina (posl. prostor) } \\
\text { Terjatve za nevplačan } \\
\text { vpoklican kapital }\end{array}$} & SREDSTVA & $\begin{array}{c}\text { OBV. DO } \\
\text { VIROV SRED. }\end{array}$ & \multirow[b]{2}{*}{$\begin{array}{l}\text { Nevpoklican kapital kot } \\
\text { odbitna postavka } \\
\text { Osnovni kapital }\end{array}$} \\
\hline & 10.000 & $\begin{array}{l}-2.000 \\
20.000\end{array}$ & \\
\hline & & & 10.000 Družbenik. $A A(0,5)$ \\
\hline Denarna sredstva (na TR) & 8.000 & & \\
\hline SKUPAJ SRED. >> & 18.000 & 18.000 & $<<$ SKUPAJ OBV. \\
\hline
\end{tabular}

Ko družba kliče na vplačilo preostanka osnovnega vložka:

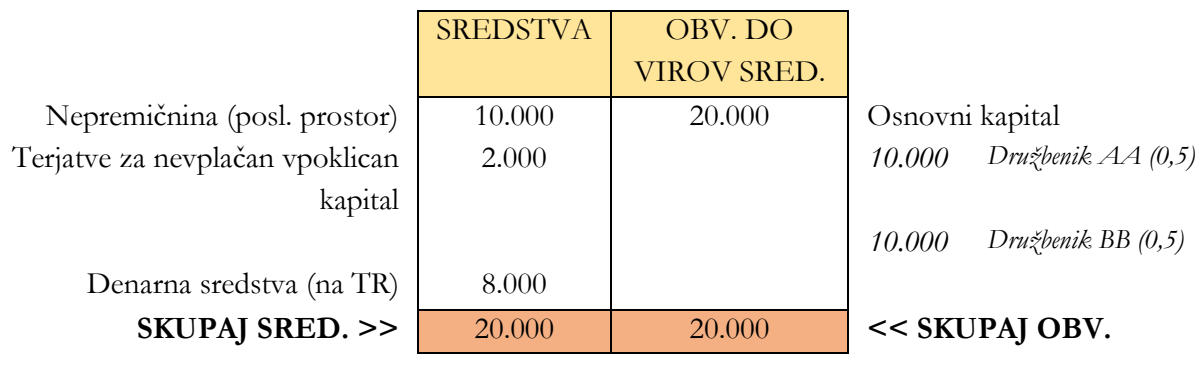




\section{SKLOP VAJ Z OZNAKO: B}

\section{Vaja B1}

Osebi AA in BB sta na začetku leta ustanovili B1 d.o.o. z 10.000 EUR osnovnega kapitala. Obe sta zagotovili 5.000 EUR denarnega vložka in takoj ob ustanovitvi tudi vplačali denarna sredstva v celoti na transakcijski račun novoustanovljene družbe.

V družbi B1 d.o.o. se tekom leta zgodita naslednja poslovna dogodka:

- Družba B1 d.o.o. na začetku leta kupi delnice druge družbe ZZ d.d. v skupni vrednosti 8.000 EUR. Kupljene delnice plača takoj z nakazilom denarnih sredstev s transakcijskega računa družbe prodajalcu delnic. (Opomba: stroškov $\mathrm{v}$ zvezi s prenosom delnic ni.)

- Družba B1 d.o.o. pred koncem leta prejme dividende od družbe ZZ d.d. v skupni vrednosti 1.000 EUR. Nakazilo je bilo izvršeno na transakcijski račun družbe B1 d.o.o. (Opomba: davščin v zvezi z nakazilom dividend oz. potrebe po akontaciji davščin ni.)

Naloga in vprašanja (z navodili):

- Izdelajte poenostavljeno shemo bilance stanja družbe B1 d.o.o. na začetku leta. 
- Izdelajte poenostavljeno shemo izkaza poslovnega izida družbe B1 d.o.o. za poslovno leto. (Opomba: davka na dobiček - natančneje: davka od dohodka pravnih oseb - ni.)

- Če ima, katere prihodke in/ali odhodke ima družba? Koliko?

- Kateri je poslovni izid? Kolikšen?

- Izdelajte poenostavljeno shemo bilance stanja družbe B1 d.o.o. na koncu leta.

- Katera sredstva (premoženje) in obveznosti (do virov sredstev) ima družba? Koliko?

- Kolikšna je knjigovodska vrednost kapitala družbe?

- Kolikšna je knjigovodska vrednost poslovnega deleža vsakega družbenika?

(Opomba: prikažite izračune in zapisite odgovore.)

Vsebina / smoter naloge je usvojiti naslednje pojme in problematiko:

- Povečanje koristi podjetja = prihodek .

- Izkaz poslovnega izida.

\section{Rešitev}

Izkaz poslovnega izida

\begin{tabular}{|c|c|c|c|}
\hline \multirow{3}{*}{ Dobiček $>>$} & ODHODKI & PRIHODKI & \multirow[b]{2}{*}{ Prihodki (prejete dividende) } \\
\hline & & 1.000 & \\
\hline & 1.000 & & $<$ Izguba \\
\hline KUPAJ AKT. STRAN >> & 1.000 & 1.000 & $<<$ SKUPAJ PAS. STRAN \\
\hline
\end{tabular}

Bilanca stanja

\begin{tabular}{|c|c|c|c|}
\hline \multirow{4}{*}{$\begin{array}{r}\text { Finančna naložba (delnice) } \\
\text { Denarna sredstva (na TR) }\end{array}$} & SREDSTVA & OBV. DO & \multirow{2}{*}{ Osnovni kapital (vpoklican) } \\
\hline & 8.000 & $\frac{\text { VIROV SRED. }}{10.000}$ & \\
\hline & 3.000 & & $\begin{array}{ll}5.000 & \text { Družbenik, } A A \\
& (0,5) \\
5.000 & \begin{array}{l}\text { Dru约enik } B B \\
(0,5)\end{array}\end{array}$ \\
\hline & & 1.000 & $<$ Posl. izid (dobiček iz IPI) \\
\hline SKUPAJ SRED. >> & 11.000 & 11.000 & < SKUPAJ OBV. \\
\hline
\end{tabular}




\section{Vaja B2}

Osebi AA in BB sta na začetku leta ustanovili B2 d.o.o. z 10.000 EUR osnovnega kapitala. Obe sta zagotovili 5.000 EUR denarnega vložka in takoj ob ustanovitvi tudi vplačali denarna sredstva v celoti na transakcijski račun novoustanovljene družbe.

V družbi B2 d.o.o. se tekom leta zgodita naslednja poslovna dogodka:

- Družba B2 d.o.o. na začetku leta izda obveznice v skupni vrednosti 10.000 EUR, ki jih uspešno proda. Prodane obveznice plača kupec banka BANKA d.d. takoj z nakazilom denarnih sredstev na transakcijski račun družbe B2 d.o.o. (Opomba: stroškov v zvezi z izdajo in prodajo obveznic ni.)

- Družba B2 d.o.o. pred koncem leta obračuna (kuponske) obresti iz naslova izdane obveznice v skupni vrednosti 2.000 EUR. Obresti je nakazala na transakcijski račun banke BANKA d.d. (Opomba: stroškov in davščin v zvezi z nakazilom obresti ni.)

Naloga in vprašanja (そ.navodili):

- Izdelajte poenostavljeno shemo bilance stanja družbe B2 d.o.o. na začetku leta.

- Izdelajte poenostavljeno shemo izkaza poslovnega izida družbe B2 d.o.o. za poslovno leto. (Opomba: davka na dobiček - natančneje: davka od dohodka pravnih oseb - ni.)

- Če ima, katere prihodke in/ali odhodke ima družba? Koliko?

- Kateri je poslovni izid? Kolikšen?

- Izdelajte poenostavljeno shemo bilance stanja družbe B2 d.o.o. na koncu leta.

- Katera sredstva (premoženje) in obveznosti (do virov sredstev) ima družba? Koliko?

- Kolikšna je knjigovodska vrednost kapitala družbe?

- Kolikšna je knjigovodska vrednost poslovnega deleža vsakega družbenika?

(Opomba: prika ǎite iæračune in zapišite odgovore.) 


\section{Rešitev}

Izkaz poslovnega izida

\begin{tabular}{|c|c|c|c|}
\hline & ODHODKI & PRIHODKI & \\
\hline $\begin{array}{l}\text { Odhodki iz naslova } \\
\text { financiranja (kup. obr.) }\end{array}$ & 2.000 & & \\
\hline Dobiček $>>$ & & 2.000 & $<<$ Izguba \\
\hline SKUPAJ AKT. STRAN >> & 2.000 & 2.000 & $<<$ SKUPAJ PAS. STRAN \\
\hline
\end{tabular}

Bilanca stanja

\begin{tabular}{|c|c|c|c|}
\hline \multirow{6}{*}{ Denarna sredstva (na TR) } & SREDSTVA & OBV. DO & \multirow[b]{2}{*}{ Osnovni kapital (vpoklican) } \\
\hline & \multirow[t]{5}{*}{18.000} & \multirow[t]{3}{*}{10.000} & \\
\hline & & & 5.000 Družbenik. $A A(0,5)$ \\
\hline & & & Družbenik BB $(0,5)$ \\
\hline & & -2.000 & \multirow{2}{*}{$\begin{array}{l}<<\text { Posl. izid (izguba iz IPI) } \\
\text { Izdane obveznice (dolžniško } \\
\text { financiranje) }\end{array}$} \\
\hline & & 10.000 & \\
\hline SKUPAJ SRED. >> & 18.000 & 18.000 & << SKUPAJ OBV. \\
\hline
\end{tabular}

\section{Vaja B3}

Osebi AA in BB sta na začetku leta ustanovili B3 d.o.o. z 10.000 EUR osnovnega kapitala. Obe sta zagotovili 5.000 EUR denarnega vložka in takoj ob ustanovitvi tudi vplačali denarna sredstva $\mathrm{v}$ celoti na transakcijski račun novoustanovljene družbe.

V družbi B3 d.o.o. se tekom leta zgodi naslednji poslovni dogodek:

- Družba B3 d.o.o. je opravila storitev pravnega svetovanja (na področju korporacijskega prava) v vrednosti 3.000 EUR za naročnika fizično osebo CC. Oseba CC je opravljeno storitev poplačal takoj z gotovino. Storitev pravnega svetovanja je bila t. i. intelektualna storitev, pri opravljanju katere družba B3 d.o.o. ni uporabila ali potrošila nobenih svojih sredstev. (Opomba: davščin npr. davka na dodano vrednost - v zvezi s prodajo storitve ni.)

Naloga in vprašanja (z navodili):

- Izdelajte poenostavljeno shemo bilance stanja družbe B3 d.o.o. na začetku leta. 
- Izdelajte poenostavljeno shemo izkaza poslovnega izida družbe B3 d.o.o. za poslovno leto. (Opomba: davka na dobiček - natančneje: davka od dohodka pravnih oseb - ni.)

- Če ima, katere prihodke in/ali odhodke ima družba? Koliko?

- Kateri je poslovni izid? Kolikšen?

- Izdelajte poenostavljeno shemo bilance stanja družbe B3 d.o.o. na koncu leta.

- Katera sredstva (premoženje) in obveznosti (do virov sredstev) ima družba? Koliko?

- Kolikšna je knjigovodska vrednost kapitala družbe?

- Kolikšna je knjigovodska vrednost poslovnega deleža vsakega družbenika?

(Opomba: prikažite izračune in zapišite odgovore.)

Izkaz poslovnega izida

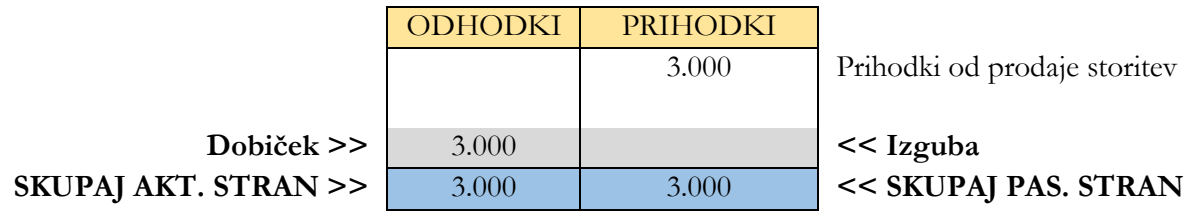

Bilanca stanja

\begin{tabular}{c|c|c|c}
\cline { 2 - 3 } Denarna sredstva (na TR) & SREDSTVA & $\begin{array}{c}\text { OBV. DO } \\
\text { VIROV SRED. }\end{array}$ & \multicolumn{1}{c}{ Osnovni kapital (vpoklican) } \\
& 13.000 & 10.000 & $5.000 \quad$ Družbenik. $A A(0,5)$ \\
& & $3.000 \quad$ Družbenik $B B(0,5)$ \\
& & 3.000 & $<$ Posl. izid (dobiček iz IPI) \\
\cline { 3 - 4 } SKUPAJ SRED. >> SKUPAJ OBV. & 13.000 &
\end{tabular}

\section{Vaja B4}

Osebi AA in BB sta na začetku leta ustanovili B4 d.o.o. z 10.000 EUR osnovnega kapitala. Obe sta zagotovili 5.000 EUR denarnega vložka in takoj ob ustanovitvi tudi vplačali denarna sredstva v celoti na transakcijski račun novoustanovljene družbe. 
V družbi B4 d.o.o. se tekom leta zgodita naslednja poslovna dogodka:

- Družba B4 d.o.o. je za izvedbo storitve davčnega svetovanja naročila storitev pregleda pri izkušenem davčnem svetovalcu v vrednosti 2.000 EUR. Družba B4 d.o.o. je kupljeno storitev davčnemu svetovalcu plačala takoj z nakazilom $\mathrm{s}$ svojega transakcijskega računa. (Opomba: davščin - npr. davka na dodano vrednost - v zvezi z nakupom storitve ni.)

- Družba B4 d.o.o. je opravila storitev davčnega svetovanja v vrednosti 4.000 EUR za naročnika fizično osebo CC. Oseba CC je opravljeno storitev poplačal takoj z gotovino. Storitev davčnega svetovanja je bila t. i. intelektualna storitev. (Opomba: davščin - npr. davka na dodano vrednost - v zvezi s prodajo storitve ni.)

\section{Naloga in vprašanja (z navodili):}

- Izdelajte poenostavljeno shemo bilance stanja družbe B4 d.o.o. na začetku leta.

- Izdelajte poenostavljeno shemo izkaza poslovnega izida družbe B4 d.o.o. za poslovno leto. (Opomba: davka na dobiček - natančneje: davka od dohodka pravnih oseb - ni.)

- Če ima, katere prihodke in/ali odhodke ima družba? Koliko?

- Kateri je poslovni izid? Kolikšen?

- Izdelajte poenostavljeno shemo bilance stanja družbe B4 d.o.o. na koncu leta.

- Katera sredstva (premoženje) in obveznosti (do virov sredstev) ima družba? Koliko?

- Kolikšna je knjigovodska vrednost kapitala družbe?

- Kolikšna je knjigovodska vrednost poslovnega deleža vsakega družbenika?

(Opomba: prikařite ižračune in zapišite odgovore.)

\section{Vsebina / smoter naloge je usvojiti naslednje pojme in problematiko:}

- Poslovni izid: dobiček ali izguba = razlika med prihodki in odhodki.

- Čisti dobiček, čista izguba.

- Vpliv na »kapital«. 


\section{Rešitev}

Izkaz poslovnega izida

\begin{tabular}{|c|c|c|c|}
\hline \multirow{4}{*}{$\begin{array}{r}\text { Odhodki (stroški kupljenih } \\
\text { storitev) } \\
\text { Dobiček }>> \\
\text { SKUPAI AKT. STRAN >> }\end{array}$} & ODHODKI & PRIHODKI & \multirow{4}{*}{$\begin{array}{l}\text { Prihodki od prodaje storitev } \\
<<\text { Izguba } \\
<<\text { SKUPAJ PAS. STRAN }\end{array}$} \\
\hline & 2.000 & 4.000 & \\
\hline & 2.000 & & \\
\hline & 4.000 & 4.000 & \\
\hline
\end{tabular}

Bilanca stanja

\begin{tabular}{|c|c|c|c|}
\hline \multirow{5}{*}{ Denarna sredstva (na TR) } & SREDSTVA & OBV. DO & \multirow[b]{2}{*}{ Osnovni kapital (vpoklican) } \\
\hline & \multirow[t]{4}{*}{12.000} & 10.000 & \\
\hline & & & 5.000 Družbenik $A A(0,5)$ \\
\hline & & & 5.000 Družbenik BB $(0,5)$ \\
\hline & & 2.000 & \multirow{2}{*}{$\begin{array}{l}<\text { Posl. izid (dobiček iz IPI) } \\
<<\text { SKUPAJ OBV. }\end{array}$} \\
\hline SKUPAJ SRED. >> & 12.000 & 12.000 & \\
\hline
\end{tabular}

\section{Vaja B5}

Osebi AA in BB sta na začetku leta ustanovili B5 d.o.o. z 10.000 EUR osnovnega kapitala. Obe sta zagotovili 5.000 EUR denarnega vložka in takoj ob ustanovitvi tudi vplačali denarna sredstva v celoti na transakcijski račun novoustanovljene družbe.

V družbi B5 d.o.o. se tekom leta zgodijo naslednji poslovni dogodki:

- Družba B5 d.o.o. je opravila storitev pravnega svetovanja (na področju korporacijskega prava in davčnega prava) v vrednosti 5.000 EUR za naročnika fizično osebo CC. Oseba CC je opravljeno storitev poplačala takoj z nakazilom na transakcijski račun družbe B5 d.o.o. Storitev pravnega svetovanja je bila t. i. intelektualna storitev. (Opomba: davščin - npr. davka na dodano vrednost - v zvezi s prodajo storitve ni.)

- Družba B5 d.o.o. je obračunala delo, ki ga je opravila pri njej zaposlena oseba DD v času izvajanja storitve. Skupna vrednost obračunanega dela je 4.000 EUR. Družba B5 d.o.o. je v zvezi z obračunanim delom izvedla nakazili s svojega transakcijskega računa osebi DD in v državni proračun.

- Družba B5 d.o.o. je za izvedbo storitve na področju davčnega prava naročila storitev pregleda pri izkušenem davčnem svetovalcu v vrednosti 2.000 EUR. Družba B5 d.o.o. je kupljeno storitev davčnemu svetovalcu plačala takoj z 
nakazilom s svojega transakcijskega računa. (Opomba: davščin - npr. davka na dodano vrednost - v zvezi z nakupom storitve ni.)

Naloga in vprašanja (z. navodili):

- Izdelajte poenostavljeno shemo bilance stanja družbe B5 d.o.o. na začetku leta.

- Izdelajte poenostavljeno shemo izkaza poslovnega izida družbe B5 d.o.o. za poslovno leto. (Opomba: davka na dobiček - natančneje: davka od dohodka pravnih oseb - ni.)

- Če ima, katere prihodke in/ali odhodke ima družba? Koliko?

- Kateri je poslovni izid? Kolikšen?

- Izdelajte poenostavljeno shemo bilance stanja družbe B5 d.o.o. na koncu leta.

- Katera sredstva (premoženje) in obveznosti (do virov sredstev) ima družba? Koliko?

- Kolikšna je knjigovodska vrednost kapitala družbe?

- Kolikšna je knjigovodska vrednost poslovnega deleža vsakega družbenika?

(Opomba: prikařite izračune in zapisite odgovore.)

Rešitev

Izkaz poslovnega izida

\begin{tabular}{|c|c|c|c|}
\hline \multirow{3}{*}{$\begin{array}{r}\text { Odhodki (stroški dela/plač) } \\
\text { Odhodki (stroški kupljenih } \\
\text { storitev) }\end{array}$} & ODHODKI & PRIHODKI & \multirow[b]{2}{*}{ Prihodki od prodaje storitev } \\
\hline & 4.000 & 5.000 & \\
\hline & 2.000 & & \\
\hline Dobiček $>>$ & & 1.000 & $<<$ Izguba \\
\hline SKUPAJ AKT. STRAN >> & 6.000 & 6.000 & $<<$ SKUPAJ PAS. STRAN \\
\hline
\end{tabular}

Bilanca stanja

\begin{tabular}{|c|c|c|c|}
\hline \multirow{5}{*}{ Denarna sredstva (na TR) } & SREDSTVA & OBV. DO & \multirow[b]{2}{*}{ Osnovni kapital (vpoklican) } \\
\hline & \multirow[t]{4}{*}{9.000} & \multirow[t]{3}{*}{10.000} & \\
\hline & & & 5.000 Družbenik $A A(0,5)$ \\
\hline & & & Drū̌benik. BB $(0,5)$ \\
\hline & & -1.000 & \multirow{2}{*}{$\begin{array}{l}<<\text { Posl. izid (izguba iz IPI) } \\
<<\text { SKUPAJ OBV. }\end{array}$} \\
\hline SKUPAJ SRED. >> & 9.000 & 9.000 & \\
\hline
\end{tabular}




\section{Vaja B6}

Osebi AA in BB sta na začetku leta ustanovili B6 d.o.o. z 10.000 EUR osnovnega kapitala. Obe sta zagotovili 5.000 EUR denarnega vložka in takoj ob ustanovitvi tudi vplačali denarna sredstva v celoti na transakcijski račun novoustanovljene družbe.

V družbi B6 d.o.o. se tekom leta zgodijo naslednji poslovni dogodki:

- Družba B6 d.o.o. je opravila storitev pravnega svetovanja (na področju korporacijskega prava in davčnega prava) v vrednosti 10.000 EUR za naročnika fizično osebo CC. Oseba CC je opravljeno storitev poplačala takoj z nakazilom na transakcijski račun družbe B6 d.o.o. Storitev pravnega svetovanja je bila t. i. intelektualna storitev. (Opomba: davščin - npr. davka na dodano vrednost - v zvezi s prodajo storitve ni.).

- Družba B6 d.o.o. je zaradi opravljanja naročene storitve prepoznala potrebo po raznovrstnem pisarniškem materialu (redniki, mape, papir, pisala itd.). Vse to je družba v skupni vrednosti 1.000 EUR kupila pri različnih dobaviteljih, katerim je družba poplačala takoj ob nakupu z gotovino. Ves pisarniški material je družba porabila pri opravljanju naročene storitve.

- Družba B6 d.o.o. je obračunala delo, ki ga je opravila pri njej zaposlena oseba DD v času izvajanja storitve. Skupna vrednost obračunanega dela je 6.000 EUR. Družba B6 d.o.o. je v zvezi z obračunanim delom izvedla nakazili s svojega transakcijskega računa osebi DD in $\mathrm{v}$ državni proračun.

\section{Naloga in vprašanja (z.navodili):}

- Izdelajte poenostavljeno shemo bilance stanja družbe B6 d.o.o. na začetku leta.

- Izdelajte poenostavljeno shemo izkaza poslovnega izida družbe B6 d.o.o. za poslovno leto. (Opomba: davka na dobiček - natančneje: davka od dohodka pravnih oseb - ni.)

- Če ima, katere prihodke in/ali odhodke ima družba? Koliko?

- Kateri je poslovni izid? Kolikšen?

- Izdelajte poenostavljeno shemo bilance stanja družbe B6 d.o.o. na koncu leta.

- Katera sredstva (premoženje) in obveznosti (do virov sredstev) ima družba? Koliko?

- Kolikšna je knjigovodska vrednost kapitala družbe?

- Kolikšna je knjigovodska vrednost poslovnega deleža vsakega družbenika? 
(Opomba: prikažite iæračune in zapišite odgovore.)

Rešitev

Izkaz poslovnega izida

\begin{tabular}{r|c|c|l}
\cline { 2 - 3 } & ODHODKI & PRIHODKI & \multirow{2}{*}{ Prihodki od prodaje storitev } \\
\cline { 2 - 3 } Odhodki (stroški dela/plač) & 6.000 & 10.000 & \\
Odhodki (stroški porab. mat.) & 1.000 & & \\
Dobiček $>>$ & 3.000 & & \multirow{2}{*}{ < Izguba } \\
\cline { 2 - 3 } SKUPAJ AKT. STRAN $>>$ SKUPJ PAS. STRAN & 10.000 & 10.000 &
\end{tabular}

Bilanca stanja

\begin{tabular}{|c|c|c|c|}
\hline \multirow{5}{*}{ Denarna sredstva (na TR) } & SREDSTVA & OBV. DO & \multirow[b]{2}{*}{ Osnovni kapital (vpoklican) } \\
\hline & \multirow[t]{4}{*}{13.000} & \multirow[t]{3}{*}{10.000} & \\
\hline & & & 5.000 Drušbenik $A A(0,5)$ \\
\hline & & & 5.000 Družbenik. BB $(0,5)$ \\
\hline & & 3.000 & \multirow{2}{*}{$\begin{array}{l}<\text { Posl. izid (dobiček iz IPI) } \\
<<\text { SKUPAI OBV. }\end{array}$} \\
\hline SKUPAJ SRED. >> & 13.000 & 13.000 & \\
\hline
\end{tabular}

\section{Vaja B7}

Osebi AA in BB sta na začetku leta ustanovili B7 d.o.o. z 10.000 EUR osnovnega kapitala. Obe sta zagotovili 5.000 EUR denarnega vložka in takoj ob ustanovitvi tudi vplačali denarna sredstva v celoti na transakcijski račun novoustanovljene družbe.

V družbi B7 d.o.o. se tekom leta zgodijo naslednji poslovni dogodki:

- Družba B7 d.o.o. je zaradi načrtovanega opravljanja storitev pravnega svetovanja potrebovala več računalniških in drugih pripomočkov (računalnik, tiskalnik, kopirni stroj itd.). Takoj na začetku leta je družba pripomočke $\mathrm{v}$ vrednosti 4.000 EUR kupila pri dobavitelju družbi RR d.o.o., kateri je poplačala takoj z nakazilom denarnih sredstev s svojega transakcijskega računa. (Opomba: davščin - npr. davka na dodano vrednost $-\mathrm{v}$ zvezi z nakupom pripomočkov ni.)

- Družba B7 d.o.o. je pripomočke uporabljala celo leto, zaradi česar je obračunala t. i. amortizacijo zanje v vrednosti 2.000 EUR. (Opomba: družba uporablja metodo enakomernega časovnega amortiziranja. Letna amortizacijska stopnja za računalniške pripomočke je $50 \%$.) 
- Družba B7 d.o.o. je opravila storitev pravnega svetovanja (na področju korporacijskega prava in davčnega prava) v vrednosti 14.000 EUR za naročnika fizično osebo CC. Oseba CC je opravljeno storitev poplačala takoj z nakazilom na transakcijski račun družbe B7 d.o.o. Storitev pravnega svetovanja je bila t. i. intelektualna storitev. (Opomba: davščin - npr. davka na dodano vrednost $-\mathrm{v}$ zvezi s prodajo storitve ni.)

- Družba B7 d.o.o. je obračunala delo, ki ga je opravila pri njej zaposlena oseba DD v času izvajanja storitve. Skupna vrednost obračunanega dela je 8.000 EUR. Družba B7 d.o.o. je v zvezi z obračunanim delom izvedla nakazili s svojega transakcijskega računa osebi DD in v državni proračun.

Naloga in uprašanja (z navodili):

- Izdelajte poenostavljeno shemo bilance stanja družbe B7 d.o.o. na začetku leta.

- Izdelajte poenostavljeno shemo izkaza poslovnega izida družbe B7 d.o.o. za poslovno leto. (Opomba: davka na dobiček - natančneje: davka od dohodka pravnih oseb - ni.)

- Če ima, katere prihodke in/ali odhodke ima družba? Koliko?

- Kateri je poslovni izid? Kolikšen?

- Izdelajte poenostavljeno shemo bilance stanja družbe B7 d.o.o. na koncu leta.

- Katera sredstva (premoženje) in obveznosti (do virov sredstev) ima družba? Koliko?

- Kolikšna je knjigovodska vrednost kapitala družbe?

- Kolikšna je knjigovodska vrednost poslovnega deleža vsakega družbenika?

(Opomba: prikařite iæračune in zapišite odgovore.)

Vsebina / smoter naloge je usvojiti naslednje pojme in problematiko:

- amortizacija. 


\section{Rešitev}

Izkaz poslovnega izida

\begin{tabular}{r|c|c|c}
\cline { 2 - 3 } & ODHODKI & PRIHODKI & \multirow{2}{*}{ Prihodki od prodaje storitev } \\
\cline { 3 - 3 } $\begin{array}{r}\text { Odhodki (stroški } \\
\text { amortizacije) }\end{array}$ & 2.000 & 14.000 & \\
Odhodki (stroški dela/plač) & 8.000 & & \\
Dobiček $>>$ & 4.000 & & \multirow{2}{*}{ < Izguba } \\
SKUPAJ AKT. STRAN $>>$ SKUPAJ PAS. STRAN & 14.000 & 14.000 &
\end{tabular}

Bilanca stanja

\begin{tabular}{|c|c|c|c|}
\hline \multirow{4}{*}{$\begin{array}{l}\text { Osnovna sredstva (rač. prip.) } \\
\text { Denarna sredstva (na TR) }\end{array}$} & SREDSTVA & $\begin{array}{l}\text { OBV. DO } \\
\text { VIROV SRED. }\end{array}$ & \multirow[b]{2}{*}{ Osnovni kapital (vpoklican) } \\
\hline & \multirow{3}{*}{$\begin{array}{c}2.000 \\
12.000\end{array}$} & 10.000 & \\
\hline & & & $\begin{array}{ll}5.000 & \text { Drušbenik. } A A(0,5) \\
5.000 & \text { Drušbenik } B B(0,5)\end{array}$ \\
\hline & & 4.000 & $<<$ Posl. izid (dobiček iz IPI) \\
\hline SKUPAJ SRED. >> & 14.000 & 14.000 & << SKUPAJ OBV. \\
\hline
\end{tabular}

\section{Vaja B8}

Osebi AA in BB sta na začetku leta ustanovili B8 d.o.o. z 10.000 EUR osnovnega kapitala. Obe sta zagotovili 5.000 EUR denarnega vložka in takoj ob ustanovitvi tudi vplačali denarna sredstva v celoti na transakcijski račun novoustanovljene družbe.

V družbi B8 d.o.o. se tekom leta zgodijo naslednji poslovni dogodki:

- Družba B8 d.o.o. je zaradi načrtovanega opravljanja storitev pravnega svetovanja potrebovala več računalniških in drugih pripomočkov (računalnik, tiskalnik, kopirni stroj itd.). Takoj na začetku leta je družba pripomočke v vrednosti 6.000 EUR kupila pri dobavitelju družbi PP d.o.o., kateri je poplačala takoj z nakazilom denarnih sredstev s svojega transakcijskega računa. (Opomba: davščin - npr. davka na dodano vrednost - v zvezi z nakupom pripomočkov ni.)

- Družba B8 d.o.o. je pripomočke uporabljala celo leto, zaradi česar je obračunala t. i. amortizacijo zanje v vrednosti 3.000 EUR. (Opomba: družba uporablja metodo enakomernega časovnega amortiziranja. Letna amortizacijska stopnja za računalniške pripomočke je $50 \%$.) 
- Poslovodstvo družbe B8 d.o.o. je ocenilo, da potrebuje dodatna denarna sredstva za svoje poslovanje. Družba je zato takoj po ustanovitvi najela 10.000 EUR posojila pri (nepovezani) družbi POSOJA d.o.o. Posojilodajalec tudi nakaže posojilo družbi na njen transakcijski račun. (Opomba: stroškov najema posojila ni.)

- Družba B8 d.o.o. pred koncem leta prejme obračun obresti iz naslova najetega posojila v skupni vrednosti 1.000 EUR. Obresti je nakazala na transakcijski račun družbe POSOJA d.o.o. (Opomba: stroškov in davščin v zvezi z nakazilom obresti ni.)

- Družba B8 d.o.o. je opravila storitev pravnega svetovanja (na področju korporacijskega prava in davčnega prava) v vrednosti 15.000 EUR za naročnika fizično osebo CC. Oseba CC je opravljeno storitev poplačala takoj z nakazilom na transakcijski račun družbe B8 d.o.o. Storitev pravnega svetovanja je bila t. i. intelektualna storitev. (Opomba: davščin - npr. davka na dodano vrednost - v zvezi s prodajo storitve ni.)

- Družba B8 d.o.o. je obračunala delo, ki ga je opravila pri njej zaposlena oseba DD v času izvajanja storitve. Skupna vrednost obračunanega dela je 10.000 EUR. Družba B8 d.o.o. je v zvezi z obračunanim delom izvedla nakazili s svojega transakcijskega računa osebi DD in v državni proračun.

\section{Naloga in uprašanja (z navodili):}

- Izdelajte poenostavljeno shemo bilance stanja družbe B8 d.o.o. na začetku leta.

- Izdelajte poenostavljeno shemo izkaza poslovnega izida družbe B8 d.o.o. za poslovno leto. (Opomba: davka na dobiček - natančneje: davka od dohodka pravnih oseb - ni.)

- Če ima, katere prihodke in/ali odhodke ima družba? Koliko?

- Kateri je poslovni izid? Kolikšen?

- Izdelajte poenostavljeno shemo bilance stanja družbe B8 d.o.o. na koncu leta.

- Katera sredstva (premoženje) in obveznosti (do virov sredstev) ima družba? Koliko?

- Kolikšna je knjigovodska vrednost kapitala družbe?

- Kolikšna je knjigovodska vrednost poslovnega deleža vsakega družbenika?

(Opomba: prikažite iæračune in zapišite odgovore.) 


\section{Rešitev}

Izkaz poslovnega izida

\begin{tabular}{r|c|c|c}
\cline { 3 - 3 } & ODHODKI & PRIHODKI & \multirow{2}{*}{ Prihodki od prodaje storitev } \\
\cline { 3 - 3 } Odhodki (stroški & 3.000 & 15.000 & \\
amortizacije) & & & \\
Odhodki (stroški dela/plač) & 10.000 & & \\
Odhodki (stroški obresti & 1.000 & & \\
zaradi fin.) & & & \\
Dobiček $>>$ & 1.000 & Izguba \\
\cline { 3 - 3 } SKUPAJ AKT. STRAN $>>>$ SKUPAJ PAS. STRAN
\end{tabular}

Bilanca stanja

\begin{tabular}{|c|c|c|c|}
\hline \multirow{6}{*}{$\begin{array}{r}\text { Osnovna sredstva (rač. prip.) } \\
\text { Denarna sredstva (na TR) }\end{array}$} & SREDSTVA & $\begin{array}{c}\text { OBV. DO } \\
\text { OBV }\end{array}$ & \multirow[b]{2}{*}{ Osnovni kapital (vpoklican) } \\
\hline & \multirow{5}{*}{$\begin{array}{c}3.000 \\
18.000\end{array}$} & \multirow[t]{3}{*}{10.000} & \\
\hline & & & 5.000 Družbenik. $A A(0,5)$ \\
\hline & & & 5.000 Družbenik BB $(0,5)$ \\
\hline & & 1.000 & \multirow{3}{*}{$\begin{array}{l}<<\text { Posl. izid (dobiček iz IPI) } \\
\text { Dolgovi za najeto posojilo } \\
\text { (POSOJA d.o.o.) } \\
<<\text { SKUPAJ OBV. }\end{array}$} \\
\hline & & 10.000 & \\
\hline SKUPAJ SRED. >> & 21.000 & 21.000 & \\
\hline
\end{tabular}

\section{Vaja B9}

Osebi AA in BB sta na začetku leta ustanovili B9 d.o.o. z 10.000 EUR osnovnega kapitala. Obe sta zagotovili 5.000 EUR denarnega vložka in takoj ob ustanovitvi tudi vplačali denarna sredstva v celoti na transakcijski račun novoustanovljene družbe.

V družbi B9 d.o.o. se tekom leta zgodijo naslednji poslovni dogodki:

- Družba B9 d.o.o. je na začetku leta izdala obveznice v skupni vrednosti 10.000 EUR, ki jih uspešno prodala. Prodane obveznice je plačal kupec banka BANKA d.d. takoj z nakazilom denarnih sredstev na transakcijski račun družbe B9 d.o.o. (Opomba: stroškov v zvezi z izdajo in prodajo obveznic ni.)

- Družba B9 d.o.o. pred koncem leta obračuna (kuponske) obresti iz naslova izdane obveznice $\mathrm{v}$ skupni vrednosti 2.000 EUR. Obresti je nakazala na transakcijski račun banke BANKA d.d. (Opomba: stroškov in davščin v zvezi z nakazilom obresti ni.) 
- Poslovodstvo družbe B9 d.o.o. je takoj po ustanovitvi odobrilo posojilo v višini 15.000 EUR (nepovezani) družbi KARTA d.o.o. Družba kot posojilodajalec je tudi nakazala posojilo družbi posojilojemalki na njen transakcijski račun. (Opomba: stroškov v zvezi z odobritvijo in nakazilom posojila ni.)

- Družba B9 d.o.o. pred koncem leta obračuna obresti iz naslova danega posojila v skupni vrednosti 3.000 EUR. Obresti je prejela nakazane na svoj transakcijski račun s strani posojilojemalke družbe KARTA d.o.o. (Opomba: stroškov in davščin v zvezi s prejemom nakazila obresti ni.)

- Družba B9 d.o.o. je za izvedbo storitve dajanja posojila naročila storitev bonitetnega pregleda možnega posojilojemalca pri izkušenem analitiku v vrednosti 1.000 EUR. Družba B9 d.o.o. je kupljeno storitev izkušenemu analitiku plačala takoj z nakazilom s svojega transakcijskega računa. (Opomba: davščin - npr. davka na dodano vrednost - v zvezi z nakupom storitve ni.)

- Družba B9 d.o.o. je obračunala delo, ki ga je opravila pri njej zaposlena oseba CC v času izvajanja storitve. Skupna vrednost obračunanega dela je 3.000 EUR. Družba B9 d.o.o. je v zvezi z obračunanim delom izvedla nakazili s svojega transakcijskega računa osebi CC in v državni proračun.

Naloga in vprašanja (z.navodili):

- Izdelajte poenostavljeno shemo bilance stanja družbe B9 d.o.o. na začetku leta.

- Izdelajte poenostavljeno shemo izkaza poslovnega izida družbe B9 d.o.o. za poslovno leto. (Opomba: davka na dobiček - natančneje: davka od dohodka pravnih oseb - ni.)

- Če ima, katere prihodke in/ali odhodke ima družba? Koliko?

- Kateri je poslovni izid? Kolikšen?

- Izdelajte poenostavljeno shemo bilance stanja družbe B9 d.o.o. na koncu leta.

- Katera sredstva (premoženje) in obveznosti (do virov sredstev) ima družba? Koliko?

- Kolikšna je knjigovodska vrednost kapitala družbe?

- Kolikšna je knjigovodska vrednost poslovnega deleža vsakega družbenika?

(Opomba: prikařite izračune in zapišite odgovore.) 


\section{Rešitev}

Izkaz poslovnega izida

\begin{tabular}{|c|c|c|c|}
\hline & ODHODKI & PRIHODKI & \\
\hline $\begin{array}{r}\text { Odhodki (stroški kupljenih } \\
\text { storitev) }\end{array}$ & 1.000 & 3.000 & $\begin{array}{l}\text { Prihodki od prejetih obresti } \\
\text { (za dano posojilo) }\end{array}$ \\
\hline Odhodki (stroški dela/plač) & 3.000 & & \\
\hline $\begin{array}{r}\text { Odhodki (stroški obresti } \\
\text { zaradi izd. obv.) }\end{array}$ & 2.000 & & \\
\hline Dobiček $>>$ & & 3.000 & $<<$ Izguba \\
\hline SKUPAJ AK'T. STRAN >> & 6.000 & 6.000 & $<<$ SKUPAJ PAS. STRAN \\
\hline
\end{tabular}

Bilanca stanja

\begin{tabular}{|c|c|c|c|}
\hline \multirow{4}{*}{$\begin{array}{r}\text { Finančna naložba (dano } \\
\text { posojilo) } \\
\text { Denarna sredstva (na TR) }\end{array}$} & SREDSTVA & $\begin{array}{c}\text { OBV. DO } \\
\text { VIROV SRED. }\end{array}$ & \multirow[b]{2}{*}{ Osnovni kapital (vpoklican) } \\
\hline & 15.000 & \multirow[t]{3}{*}{10.000} & \\
\hline & \multirow[t]{4}{*}{2.000} & & 5.000 Druǧbenik, $A A(0,5)$ \\
\hline & & & 5.000 Družbenik BB $(0,5)$ \\
\hline & & -3.000 & $<<$ Posl. izid (izguba iz IPI) \\
\hline & & 10.000 & $\begin{array}{l}\text { Dolgovi za izdane obveznice } \\
\text { (BANKA d.d.) }\end{array}$ \\
\hline SKUPAJ SRED. >> & 17.000 & 17.000 & $<<$ SKUPAJ OBV. \\
\hline
\end{tabular}

Vaja B10

Osebi AA in BB sta na začetku leta ustanovili B10 d.o.o. z 10.000 EUR osnovnega kapitala. Obe sta zagotovili 5.000 EUR denarnega vložka in takoj ob ustanovitvi tudi vplačali denarna sredstva v celoti na transakcijski račun novoustanovljene družbe.

V družbi B10 d.o.o. se tekom leta zgodita naslednja poslovna dogodka:

- Družba B10 d.o.o. je načrtovala začetek proizvodnje izdelka, vendar na začetku leta ni imela potrebnega materiala, da bi lahko začela s proizvodnjo. Ker je sklenila kupo-prodajno pogodbo s kupcem MINI d.o.o., da bo zagotovila 1.000 kosov izdelka do konca leta, je poiskala in naročila enakovrsten izdelek na tujem trgu. Družba je kupila potrebno količino izdelka v skupni vrednosti 8.000 EUR pri dobavitelju, kateremu je družba poplačala takoj ob nakupu z nakazilom s svojega transakcijskega računa. (Opomba: stroškov in davščin $\mathrm{v}$ zvezi $\mathrm{z}$ nakupom izdelkov ni.) 
- Družba B10 d.o.o. je prodala celotno zalogo proizvedenega izdelka kupcu MINI d.o.o. Kupec je poplačal opravljen nakup v vrednosti 10.000 EUR takoj z nakazilom na transakcijski račun družbe B10 d.o.o. (Opomba: davščin - npr. davka na dodano vrednost - v zvezi s prodajo proizvedenega izdelka ni.)

Naloga in vprašanja (z navodili):

- Izdelajte poenostavljeno shemo bilance stanja družbe B10 d.o.o. na začetku leta.

- Izdelajte poenostavljeno shemo izkaza poslovnega izida družbe B10 d.o.o. za poslovno leto. (Opomba: davka na dobiček - natančneje: davka od dohodka pravnih oseb - ni.)

- Če ima, katere prihodke in/ali odhodke ima družba? Koliko?

- Kateri je poslovni izid? Kolikšen?

- Izdelajte poenostavljeno shemo bilance stanja družbe B10 d.o.o. na koncu leta.

- Katera sredstva (premoženje) in obveznosti (do virov sredstev) ima družba? Koliko?

- Kolikšna je knjigovodska vrednost kapitala družbe?

- Kolikšna je knjigovodska vrednost poslovnega deleža vsakega družbenika?

(Opomba: prikažite izračune in zapišite odgovore.)

\section{Rešitev}

Izkaz poslovnega izida

\begin{tabular}{|c|c|c|c|}
\hline \multirow{3}{*}{$\begin{array}{l}\text { Odhodki (stroškovna } \\
\text { vrednost prod. proiz.) }\end{array}$} & & & \multirow{5}{*}{$\begin{array}{l}\text { Prihodki od prodaje } \\
\text { proizvodov } \\
<<\text { Izguba } \\
<<\text { SKUPAI PAS STRAN }\end{array}$} \\
\hline & ODHODKI & PRIHODKI & \\
\hline & 8.000 & 10.000 & \\
\hline Dobiček $>>$ & 2.000 & & \\
\hline KUPAJ AKT. STRAN >> & 10.000 & 10.000 & \\
\hline
\end{tabular}

Bilanca stanja

\begin{tabular}{c|c|c|c}
\cline { 2 - 3 } Denarna sredstva (na TR) & SREDSTVA & $\begin{array}{c}\text { OBV. DO } \\
\text { VIROV SRED. }\end{array}$ & \multicolumn{1}{c}{ Osnovni kapital (vpoklican) } \\
& 12.000 & 10.000 & $5.000 \quad$ Družbenik. $A A(0,5)$ \\
& & $5.000 \quad$ Družbenik $B B(0,5)$ \\
& & 2.000 & $<<$ Posl. izid (dobiček iz IPI) \\
\cline { 2 - 3 } SKUPAJ SRED. >> & 12.000 & $<$ SKUPAJ OBV.
\end{tabular}




\section{Vaja B11}

Osebi AA in BB sta na začetku leta ustanovili B11 d.o.o. z 10.000 EUR osnovnega kapitala. Obe sta zagotovili 5.000 EUR denarnega vložka in takoj ob ustanovitvi tudi vplačali denarna sredstva v celoti na transakcijski račun novoustanovljene družbe.

V družbi B11 d.o.o. se tekom leta zgodijo naslednji poslovni dogodki:

- Družba B11 d.o.o. je načrtovala začetek proizvodnje izdelka (v količini 1.000 kosov). Za izdelavo takšne količine izdelkov je potreben raznovrsten material. Ves potreben material je družba v skupni vrednosti 5.000 EUR kupila pri različnih dobaviteljih, katerim je družba poplačala takoj ob nakupu z nakazilom s svojega transakcijskega računa.

- Družba B11 d.o.o. je pri proizvodnji izdelkov ves material porabila. Družba vrednoti svoje zaloge proizvedenih izdelkov po polni stroškovni ceni. ${ }^{1}$ (Opomba: na začetku leta in na koncu leta ni nobenih zalog materiala.)

- Družba B11 d.o.o. je obračunala delo, ki ga je opravila pri njej zaposlena oseba CC v času proizvodnje izdelka (v količini 1.000 kosov). Skupna vrednost obračunanega dela je 2.000 EUR. (Opomba: družba vrednoti svoje zaloge izdelkov po polni stroškovni ceni.) Družba B11 d.o.o. je v zvezi z obračunanim delom izvedla nakazili s svojega transakcijskega računa osebi CC in v državni proračun.

\section{Naloga in vprašanja (z.navodili):}

- Izdelajte poenostavljeno shemo bilance stanja družbe B11 d.o.o. na začetku leta.

\footnotetext{
${ }_{1}$ Obstaja več različnih metod vrednotenja zalog proizvodov oz. učinkov v podjetju. Obravnava teh bi presegala namen pričujočega študijskega gradiva. V celotnem gradivu (torej pri vseh nalogah) se predpostavlja, da podjetje uporablja metodo vrednotenja zalog proizvodov po polni stroškovni ceni. Zaradi vrednotenja zalog proizvodov $\mathrm{v}$ podjetju po polni stroškovni ceni, se vsi stroški (nastali v podjetju) pripišejo ("prenesejo«) na vrednost zaloge dokončanih proizvodov (ki se izkazujejo med sredstvi v bilanci stanja). Slednja metoda je v pričujočem gradivu izbrana, ker je za bralca/-ko, ki se šele spoznava z obravnavano tematiko gospodarskih kategorij in njihovega spreminjanja ter priprave poenostavljenih shem računovodskih izkazov, uporaba te metode najenostavnejša in tako tudi pedagoško najprimernejša.

Velja opozoriti naslednje. Metoda vrednotenja zalog proizvodov po polni stroškovni ceni je metoda, ki jo podjetje lahko uporablja za namene notranjega poročanja (uporabnikom informacij znotraj podjetja), ne pa za namene zunanjega poročanja (npr. pri pripravi računovodskih izkazov za javno objavo). Za namene zunanjega poročanja Slovenski računovodski standardi (SRS) dovoljujejo uporabo ene izmed naslednje treh metod: metode vrednotenja zalog proizvodov z zoženo lastno ceno, metode vrednotenje zalog proizvodov s proizvajalnimi stroški in metode vrednotenje zalog proizvodov s spremenljivimi proizvajalnimi stroški. Mednarodni standardi računovodske poročanja (MSRP) pa dovoljuje le uporabo metode vrednotenja zalog proizvodov s proizvajalnimi stroški; preostalih metod ne.
} 
- Izdelajte poenostavljeno shemo izkaza poslovnega izida družbe B11 d.o.o. za poslovno leto. (Opomba: davka na dobiček - natančneje: davka od dohodka pravnih oseb - ni.)

- Če ima, katere prihodke in/ali odhodke ima družba? Koliko?

- Kateri je poslovni izid? Kolikšen?

- Izdelajte poenostavljeno shemo bilance stanja družbe B11 d.o.o. na koncu leta.

- Katera sredstva (premoženje) in obveznosti (do virov sredstev) ima družba? Koliko?

- Kolikšna je knjigovodska vrednost kapitala družbe?

- Kolikšna je knjigovodska vrednost poslovnega deleža vsakega družbenika?

(Opomba: prikažite iz̧ačune in zapisite odgovore.)

Vsebina / smoter naloge je usvojiti naslednje pojme in problematiko:

- Zaloge dok. proizvodov $\rightarrow$ Kakovostni postopki vrednotenja zalog (Polna stroškovna cena.)

\section{Poenostavljena (prilagojena) rešitev}

Izkaz poslovnega izida

\begin{tabular}{|c|c|c|c|}
\hline \multirow[b]{2}{*}{$\begin{array}{l}\text { Odhodki (stroškovna } \\
\text { vrednost prod. proiz.) }\end{array}$} & ODHODKI & PRIHODKI & \multirow{3}{*}{$\begin{array}{l}\text { Prihodki od prodaje } \\
\text { proizvodov } \\
<<\text { Izguba }\end{array}$} \\
\hline & & & \\
\hline Dobiček $>>$ & 0 & & \\
\hline SKUPAJ AKT. STRAN >> & 0 & 0 & $<<$ SKUPAJ PAS. STRAN \\
\hline
\end{tabular}

Bilanca stanja

\begin{tabular}{|c|c|c|c|}
\hline \multirow{5}{*}{$\begin{array}{r}\text { Zaloga dokončanih } \\
\text { proizvodov } \\
\text { Denarna sredstva (na TR) }\end{array}$} & SREDSTVA & $\begin{array}{c}\text { OBV. DO } \\
\text { VIROV SRED }\end{array}$ & \multirow[b]{2}{*}{ Osnovni kapital (vpoklican) } \\
\hline & 7.000 & 10.000 & \\
\hline & 3.000 & & 5.000 Družbenik. $A A(0,5)$ \\
\hline & & & 5.000 Družbenik $B B(0,5)$ \\
\hline & & 0 & $<<$ Posl. izid (iz IPI) \\
\hline SKUPAJ SRED. >> & 10.000 & 10.000 & << SKUPAJ OBV. \\
\hline
\end{tabular}

Obrazložitev: poenostavljeno, zaradi vrednotenja zalog proizvodov v podjetju po polni stroškovni ceni, se vsi stroški - v tej nalogi stroški porabljenega materiala in dela - pripišejo (»prenesejo«) na vrednost zaloge dokončanih proizvodov. Ker so 
stroški "preneseni« na vrednost zaloge dokončanih proizvodov, še niso preoblikovani $\mathrm{v}$ odhodke. To se praviloma zgodi šele ob opravljeni prodaji proizvodov kupcu le-teh. (Glejte npr. tudi nalogo C6.)

Poenostavljena rešitev je rešitev, ki ni v popolnosti skladna s predpisano shemo izkaza poslovnega izida v 2. odstavku 66. člena ZGD-1. Skladno s predpisano shemo je treba vizkazu poslovnega izida prikazati tudi (vsaj) postavki sprememba vrednosti zalog proizvodov in nedokončane proizvodnje ter različne vrste nastalih stroškov. Za pedagoški namen je zgornja rešitev prilagojena in ustrezna. Pravilna rešitev ( $\mathrm{z}$ obrazložitvijo) pa je predstavljena v nadaljevanju.

\section{Rešitev (z obrazložitvijo)}

Izkaz poslovnega izida

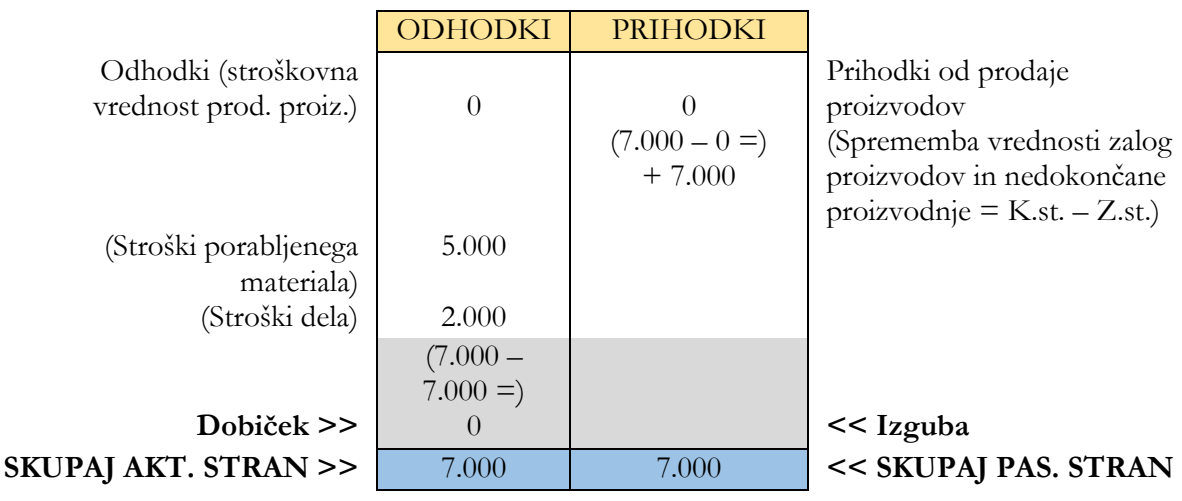

Bilanca stanja

\begin{tabular}{|c|c|c|c|}
\hline \multirow{5}{*}{$\begin{array}{r}\text { Zaloga dokončanih } \\
\text { proizvodov } \\
\text { Denarna sredstva (na TR) }\end{array}$} & SREDSTVA & $\begin{array}{c}\text { OBV. DO } \\
\text { VIROV SRED. }\end{array}$ & \multirow[b]{2}{*}{ Osnovni kapital (vpoklican) } \\
\hline & 7.000 & 10.000 & \\
\hline & 3.000 & & 5.000 Družbenik. $A A(0,5)$ \\
\hline & & & 5.000 Družbenik BB $(0,5)$ \\
\hline & & 0 & $<<$ Posl. izid (iz IPI) \\
\hline SKUPAJ SRED. >> & 10.000 & 10.000 & $<<$ SKUPAJ OBV.. \\
\hline
\end{tabular}

Obrazložitev: treba je opozoriti na vsaj dve zadevi. Poenostavljeno, prvič, pravilen poslovni izid (pri poslovanju) je tisti, pri katerem se upoštevajo samo stroški, ki se nanašajo na prodane proizvode (glejte tretji odstavek v nadaljevanju). 
Drugič, zaradi vrednotenja zalog proizvodov v podjetju po polni stroškovni ceni, se vsi stroški - $\mathrm{v}$ tej nalogi stroški porabljenega materiala in dela - obračunajo pri vrednotenju zaloge dokončanih proizvodov. V shemi izkaza poslovnega izida se to upošteva tako, da se izračuna sprememba vrednosti zalog proizvodov (in nedokončane proįvodnje), ki je razlika (+7.000 €) med vrednostjo teh zalog na koncu poslovnega obdobja $(7.000 €)$ in vrednostjo teh zalog na začetku istega poslovnega obdobja (0 $€)$. Hkrati so nastali stroški izkazani v shemi izkaza poslovnega izida po vrstah stroškov (stroški porabljenega materiala, ki so $5.000 €$; stroški dela, ki so $2.000 €$ ). Ker se v shemi izkaza poslovnega izida upošteva oboje hkrati, je v zvezi s tem poslovni izid enak nič (sprememba vrednosti zaloge $+7.000 €$; skupaj stroški -7.000 $€)$. Po vsebini slednje pomeni, da ker nastane povečanje vrednosti zalog proizvodov, so nastali stroški pri poslovanju večji od odhodkov (oboje v opazovanem poslovnem obdobju). Enostavneje: v podjetju se del nastalih stroškov "zadržuje« v povečanju zalog proizvodov (ker v obdobju ni dogodka prodaje proizvodov).

Če oz. ko se zgodi dogodek prodaje proizvodov kupcu le-teh, se vrednost zaloge dokončanih proizvodov zmanjša, hkrati pa se zmanjša v shemi izkaza poslovnega izida postavka sprememba vrednosti zalog proizvodov (in nedokončane proizvodnje). Po vsebini se $\mathrm{s}$ tem posredno stroški materiala in dela, zaobseženi $\mathrm{v}$ navedeni postavki, preoblikujejo v odhodke (tj. »ne zadržujejo« več v vrednosti zalogah proizvodov). Opozoriti velja, da hkrati seveda pri poslovnem dogodku prodaje proizvodov nastanejo tudi prihodki v zvezi z opravljeno prodajo kupcu.

\section{Vaja B12}

Osebi AA in BB sta na začetku leta ustanovili B12 d.o.o. z 10.000 EUR osnovnega kapitala. Obe sta zagotovili 5.000 EUR denarnega vložka in takoj ob ustanovitvi tudi vplačali denarna sredstva v celoti na transakcijski račun novoustanovljene družbe.

V družbi B12 d.o.o. se tekom leta zgodijo naslednji poslovni dogodki:

- Družba B12 d.o.o. je načrtovala začetek proizvodnje izdelka (v količini 1.000 kosov). Za izdelavo takšne količine izdelkov je potreben raznovrsten material. Ves potreben material je družba v skupni vrednosti 3.000 EUR kupila pri različnih dobaviteljih, katerim je družba poplačala takoj ob nakupu z nakazilom s svojega transakcijskega računa. 
- Družba B12 d.o.o. je pri proizvodnji izdelkov ves material porabila. Družba vrednoti svoje zaloge proizvedenih izdelkov po polni stroškovni ceni. ${ }^{2}$ (Opomba: na začetku leta in na koncu leta ni nobenih zalog materiala.)

- Družba B12 d.o.o. je za opravilo proizvodnje izdelkov naročila storitev opravljanja raznovrstnih del pri izkušenem proizvajalcu (kot podizvajalcu) $\mathrm{v}$ vrednosti 5.000 EUR. Družba B12 d.o.o. je kupljeno storitev izkušenega proizvajalca plačala takoj $\mathrm{z}$ nakazilom s svojega transakcijskega računa. (Opomba: davščin - npr. davka na dodano vrednost $-\mathrm{v}$ zvezi z nakupom storitve ni.)

- Družba B12 d.o.o. je prodala celotno zalogo proizvedenih izdelkov kupcu MINI d.o.o. Kupec je poplačal kupljene proizvedene izdelke v vrednosti 10.000 EUR takoj z nakazilom na transakcijski račun družbe B12 d.o.o. (Opomba: davščin npr. davka na dodano vrednost $-\mathrm{v}$ zvezi s prodajo proizvedenih izdelkov ni.).

\section{Naloga in vprašanja (z navodili):}

- Izdelajte poenostavljeno shemo bilance stanja družbe B12 d.o.o. na začetku leta.

- Izdelajte poenostavljeno shemo izkaza poslovnega izida družbe B12 d.o.o. za poslovno leto. (Opomba: davka na dobiček - natančneje: davka od dohodka pravnih oseb - ni.)

- Če ima, katere prihodke in/ali odhodke ima družba? Koliko?

- Kateri je poslovni izid? Kolikšen?

- Izdelajte poenostavljeno shemo bilance stanja družbe B12 d.o.o. na koncu leta.

- Katera sredstva (premoženje) in obveznosti (do virov sredstev) ima družba? Koliko?

- Kolikšna je knjigovodska vrednost kapitala družbe?

- Kolikšna je knjigovodska vrednost poslovnega deleža vsakega družbenika?

(Opomba: prikažite iz̧račune in zapišite odgovore.)

\footnotetext{
2 Obstaja več različnih metod vrednotenja zalog proizvodov oz. učinkov v podjetju. Podrobneje o tem glejte opombo 1.
} 


\section{Rešitev}

Izkaz poslovnega izida

\begin{tabular}{|c|c|c|c|}
\hline & ODHODKI & PRIHODKI & \multirow[b]{2}{*}{$\begin{array}{l}\text { Prihodki od prodaje } \\
\text { proizvodov }\end{array}$} \\
\hline $\begin{array}{l}\text { Odhodki (stroškovna } \\
\text { vrednost prod. proiz.): }\end{array}$ & & 10.000 & \\
\hline Odhodki (stroški porablienega & 3.000 & & \\
\hline $\begin{array}{r}\text { materiala) } \\
\text { Odhodki (stroški kupliene storitve) }\end{array}$ & & & \\
\hline Odhodki (stroški kupljene storitve) & 5.000 & & \\
\hline Dobiček >> & 2.000 & & $<<$ Izguba \\
\hline SKUPAJ AKT. STRAN >> & 10.000 & 10.000 & $<<$ SKUPAJ PAS. STRAN \\
\hline
\end{tabular}

Bilanca stanja

\begin{tabular}{|c|c|c|c|}
\hline \multirow{4}{*}{ Denarna sredstva (na TR) } & SREDSTVA & OBV. DO & \multirow{2}{*}{ Osnovni kapital (vpoklican) } \\
\hline & & VIROV SRED. & \\
\hline & \multirow{3}{*}{12.000} & & $\begin{array}{l}\text { Usnovn1 kapital (vpoklican) } \\
5.000 \text { Družbenik. } A A(0,5)\end{array}$ \\
\hline & & & 5.000 Drǔ̌benik BB $(0,5)$ \\
\hline \multirow[b]{2}{*}{ SKUPAI SRED. >> } & & 2.000 & \multirow{2}{*}{$\begin{array}{l}<<\text { Posl. izid (dobiček iz IPI) } \\
<<\text { SKUPAJ OBV. }\end{array}$} \\
\hline & 12.000 & 12.000 & \\
\hline
\end{tabular}

\section{Vaja B13}

Osebi AA in BB sta na začetku leta ustanovili B13 d.o.o. z 10.000 EUR osnovnega kapitala. Obe sta zagotovili 5.000 EUR denarnega vložka in takoj ob ustanovitvi tudi vplačali denarna sredstva $v$ celoti na transakcijski račun novoustanovljene družbe.

V družbi B13 d.o.o. se tekom leta zgodijo naslednji poslovni dogodki:

- Družba B13 d.o.o. je načrtovala začetek proizvodnje izdelka (v količini 5.000 kosov). Za izdelavo takšne količine izdelkov je potreben raznovrsten material. Ves potreben material je družba v skupni vrednosti 2.000 EUR kupila pri različnih dobaviteljih, katerim je družba poplačala takoj ob nakupu z nakazilom s svojega transakcijskega računa.

- Družba B13 d.o.o. je zaradi načrtovane proizvodnje potrebovala poseben stroj/napravo. Takoj na začetku leta je družba stroj/napravo v vrednosti 8.000 EUR kupila pri dobavitelju družbi PP d.o.o., kateri je poplačala takoj z nakazilom denarnih sredstev s svojega transakcijskega računa. (Opomba: davščin - npr. davka na dodano vrednost - v zvezi z nakupom stroja/naprave ni.) 
- Družba B13 d.o.o. je stroj/napravo uporabljala celo leto, zaradi česar je obračunala t. i. amortizacijo zanj(o) v vrednosti 2.000 EUR. (Opomba: družba uporablja metodo enakomernega časovnega amortiziranja. Letna amortizacijska stopnja za stroj/napravo je $25 \%$.).

- Družba B13 d.o.o. je pri proizvodnji izdelkov ves material porabila. Družba vrednoti svoje zaloge proizvedenih izdelkov po polni stroškovni ceni. ${ }^{3}$ (Opomba: na začetku leta in na koncu leta ni nobenih zalog materiala.).

- Družba B13 d.o.o. je obračunala delo, ki ga je opravila pri njej zaposlena oseba CC v času proizvodnje izdelka (v količini 5.000 kosov). Skupna vrednost obračunanega dela je 3.000 EUR. (Opomba: družba vrednoti svoje zaloge izdelkov po polni stroškovni ceni.) Družba B13 d.o.o. je v zvezi z obračunanim delom izvedla nakazili s svojega transakcijskega računa osebi CC in v državni proračun.

- Družba B13 d.o.o. je prodala celotno zalogo proizvedenega izdelka kupcu MINI d.o.o. Kupec je poplačal opravljen nakup v vrednosti 12.000 EUR takoj z nakazilom na transakcijski račun družbe B13 d.o.o. (Opomba: davščin - npr. davka na dodano vrednost $-\mathrm{v}$ zvezi s prodajo proizvedenega izdelka ni.).

Naloga in vprašanja (z navodili):

- Izdelajte poenostavljeno shemo bilance stanja družbe B13 d.o.o. na začetku leta.

- Izdelajte poenostavljeno shemo izkaza poslovnega izida družbe B13 d.o.o. za poslovno leto. (Opomba: davka na dobiček - natančneje: davka od dohodka pravnih oseb - ni.)

- Če ima, katere prihodke in/ali odhodke ima družba? Koliko?

- Kateri je poslovni izid? Kolikšen?

- Izdelajte poenostavljeno shemo bilance stanja družbe B13 d.o.o. na koncu leta.

- Katera sredstva (premoženje) in obveznosti (do virov sredstev) ima družba? Koliko?

- Kolikšna je knjigovodska vrednost kapitala družbe?

- Kolikšna je knjigovodska vrednost poslovnega deleža vsakega družbenika?

(Opomba:priką̧ite įračune in zapišite odgovore.)

\footnotetext{
${ }^{3}$ Obstaja več različnih metod vrednotenja zalog proizvodov oz. učinkov v podjetju. Podrobneje o tem glejte opombo 1.
} 


\section{Rešitev}

Izkaz poslovnega izida

\begin{tabular}{|c|c|c|c|}
\hline \multirow{7}{*}{$\begin{array}{r}\text { Odhodki (stroškovna } \\
\text { vrednost prod. proiz.): } \\
\text { Odhodki (stroški amortizacije) } \\
\text { Odhodki (stroški porabljenega } \\
\text { materiala) } \\
\text { Odhodki (stroški dela) } \\
\text { Dobiček }>> \\
\text { SKUPAJ AKT. STRAN >> }\end{array}$} & ODHODKI & PRIHODKI & \multirow{5}{*}{$\begin{array}{l}\text { Prihodki od prodaje } \\
\text { proizvodov }\end{array}$} \\
\hline & & \multirow[t]{4}{*}{12.000} & \\
\hline & 2.000 & & \\
\hline & 2.000 & & \\
\hline & 3.000 & & \\
\hline & 5.000 & & \multirow{3}{*}{$\begin{array}{l}<\text { Izguba } \\
<<\text { SKUPAJ PAS. STRAN }\end{array}$} \\
\hline & 12.000 & 12.000 & \\
\hline \multicolumn{3}{|c|}{ Bilanca stanja } & \\
\hline \multirow{5}{*}{$\begin{array}{l}\text { Osnovna sredstva (stroj) } \\
\text { Denarna sredstva (na TR) }\end{array}$} & SREDSTVA & $\begin{array}{c}\text { OBV. DO } \\
\text { VIROV SRED. }\end{array}$ & \multirow{6}{*}{ 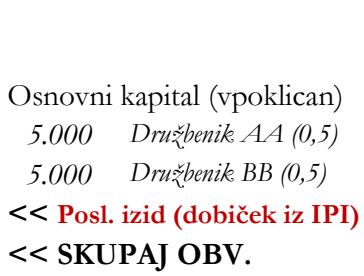 } \\
\hline & 6.000 & 10.000 & \\
\hline & 9.000 & & \\
\hline & & & \\
\hline & & 5.000 & \\
\hline SKUPAJ SRED. >> & 15.000 & 15.000 & \\
\hline
\end{tabular}

Vaja B14

Osebi AA in BB sta na začetku leta ustanovili B14 d.o.o. z 10.000 EUR osnovnega kapitala. Obe sta zagotovili 5.000 EUR denarnega vložka in takoj ob ustanovitvi tudi vplačali denarna sredstva v celoti na transakcijski račun novoustanovljene družbe.

V družbi B14 d.o.o. se tekom leta zgodijo naslednji poslovni dogodki:

- Družba B14 d.o.o. na začetku leta najame posojilo pri drugi (nepovezani) družbi POSOJA d.o.o. v skupni vrednosti 10.000 EUR. Posojilodajalec je takoj nakazal posojilo družbi na njen transakcijski račun. (Opomba: v trenutku najema posojila ni nobenih obresti, ki bi jih moral poravnati posojilojemalec. Stroškov najema posojila ni.).

- Družba B14 d.o.o. pred koncem leta prejme obračun obresti za najeto posojilo od družbe POSOJA d.o.o. v skupni vrednosti 1.000 EUR. Družba je takoj nakazala obračunane obresti na transakcijski račun posojilodajalca družbe POSOJA d.o.o. (Opomba: stroškov in davščin v zvezi z nakazilom obresti ni.). 
- Družba B14 d.o.o. je načrtovala začetek proizvodnje izdelka (v količini 10.000 kosov). Za izdelavo takšne količine izdelkov je potreben raznovrsten material. Ves potreben material je družba v skupni vrednosti 10.000 EUR kupila pri različnih dobaviteljih, katerim je družba poplačala takoj ob nakupu z nakazilom s svojega transakcijskega računa.

- Družba B14 d.o.o. je pri proizvodnji izdelkov ves material porabila. Družba vrednoti svoje zaloge proizvedenih izdelkov po polni stroškovni ceni. ${ }^{4}$ (Opomba: na začetku leta in na koncu leta ni nobenih zalog materiala.).

- Družba B14 d.o.o. je za opravilo proizvodnje izdelkov naročila več storitev opravljanja raznovrstnih del pri več izkušenih proizvajalcih podobnih izdelkov (kot podizvajalcih) v skupni vrednosti 8.000 EUR. Družba B14 d.o.o. je kupljene storitve izkušenih proizvajalcev plačala takoj z nakazili s svojega transakcijskega računa. (Opomba: davščin - npr. davka na dodano vrednost $-\mathrm{v}$ zvezi z nakupom storitev ni.).

- Družba B14 d.o.o. je na koncu leta prodala celotno zalogo proizvedenih izdelkov kupcu MAKSI d.o.o. Kupec je poplačal kupljene proizvedene izdelke v vrednosti 14.000 EUR takoj z nakazilom na transakcijski račun družbe B14 d.o.o. (Opomba: davščin - npr. davka na dodano vrednost - v zvezi s prodajo proizvedenih izdelkov ni.).

- Družba B14 d.o.o. je na začetku leta kupila delnice druge družbe ZZ d.d. v skupni vrednosti 8.000 EUR. Kupljene delnice je plačala takoj z nakazilom denarnih sredstev s transakcijskega računa družbe prodajalcu delnic. (Opomba: stroškov v zvezi s prenosom delnic ni.).

- Družba B14 d.o.o. je pred koncem leta prejela dividende od družbe ZZ d.d. v skupni vrednosti 1.000 EUR. Nakazilo je bilo izvršeno na transakcijski račun družbe B14 d.o.o. (Opomba: davščin v zvezi z nakazilom dividend oz. potrebe po akontaciji davščin ni.).

\section{Naloga in uprašanja (z navodili):}

- Izdelajte poenostavljeno shemo bilance stanja družbe B14 d.o.o. na začetku leta.

- Izdelajte poenostavljeno shemo izkaza poslovnega izida družbe B14 d.o.o. za poslovno leto. (Opomba: davka na dobiček - natančneje: davka od dohodka pravnih oseb - ni.)

- Če ima, katere prihodke in/ali odhodke ima družba? Koliko?

\footnotetext{
${ }_{4}^{4}$ Obstaja več različnih metod vrednotenja zalog proizvodov oz. učinkov v podjetju. Podrobneje o tem glejte opombo 1.
} 
- Kateri je poslovni izid? Kolikšen?

- Izdelajte poenostavljeno shemo bilance stanja družbe B14 d.o.o. na koncu leta.

- Katera sredstva (premoženje) in obveznosti (do virov sredstev) ima družba? Koliko?

- Kolikšna je knjigovodska vrednost kapitala družbe?

- Kolikšna je knjigovodska vrednost poslovnega deleža vsakega družbenika?

(Opomba: prikažite izračune in zapišite odgovore.)

Izkaz poslovnega izida

\begin{tabular}{|c|c|c|c|}
\hline \multirow{9}{*}{$\begin{array}{r}\text { Odhodki (stroškovna } \\
\text { vrednost prod. proiz.): } \\
\text { Odhodki (stroški porabljenega } \\
\text { materiala) } \\
\text { Odhodki (stroški kupljenih } \\
\text { storitev) } \\
\text { Odhodki (stroški obresti za naj. } \\
\text { posojilo) } \\
\text { Dobiček }>> \\
\text { SKUPAJ AKT. STRAN }>>\end{array}$} & ODHODKI & PRIHODKI & \multirow{4}{*}{$\begin{array}{l}\text { Prihodki od prodaje } \\
\text { proizvodov } \\
\text { Prihodki (prejete dividende) }\end{array}$} \\
\hline & \multirow{3}{*}{10.000} & \multirow{3}{*}{$\begin{array}{c}14.000 \\
1.000\end{array}$} & \\
\hline & & & \\
\hline & & & \\
\hline & \multirow[t]{2}{*}{8.000} & & \multirow{6}{*}{$\begin{array}{l}<\text { < Izguba } \\
<<\text { SKUPAJ PAS. STRAN }\end{array}$} \\
\hline & & & \\
\hline & 1.000 & & \\
\hline & & 4.000 & \\
\hline & 19.000 & 19.000 & \\
\hline \multicolumn{3}{|c|}{ Bilanca stanja } & \\
\hline \multirow{5}{*}{$\begin{array}{r}\text { Finančna naložba (delnice) } \\
\text { Denarna sredstva (na TR) }\end{array}$} & SREDSTVA & $\begin{array}{c}\text { OBV. DO } \\
\text { VIROV SRED. }\end{array}$ & \multirow{6}{*}{$\begin{array}{l}\text { Osnovni kapital (vpoklican) } \\
5.000 \text { Družbenik. } A A(0,5) \\
5.000 \text { Družbenik. BB }(0,5) \\
\text { << Posl. izid (izguba iz IPI) } \\
\text { Obveznost/dolg za najeto }\end{array}$} \\
\hline & 8.000 & 10.000 & \\
\hline & 8.000 & & \\
\hline & & -4.000 & \\
\hline & & 10.000 & \\
\hline SKUPAJ SRED. >> & 16.000 & 16.000 & \\
\hline
\end{tabular}

\section{Vaja B15}

Osebi AA in BB sta na začetku leta ustanovili B15 d.o.o. z 10.000 EUR osnovnega kapitala. Obe sta zagotovili 5.000 EUR denarnega vložka in takoj ob ustanovitvi tudi vplačali denarna sredstva v celoti na transakcijski račun novoustanovljene družbe. 
V družbi B15 d.o.o. se tekom leta zgodijo naslednji poslovni dogodki:

- Družba B15 d.o.o. je na začetku leta izdala obveznice v skupni vrednosti 15.000 EUR, ki jih uspešno prodala. Prodane obveznice je plačal kupec banka BANKA d.d. takoj z nakazilom denarnih sredstev na transakcijski račun družbe B15 d.o.o. (Opomba: stroškov v zvezi z izdajo in prodajo obveznic ni.).

- Družba B15 d.o.o. je pred koncem leta obračunala (kuponske) obresti iz naslova izdane obveznice v skupni vrednosti 3.000 EUR. Obresti je nakazala na transakcijski račun banke BANKA d.d. (Opomba: stroškov in davščin v zvezi z nakazilom obresti ni.).

- Družba B15 d.o.o. je načrtovala začetek proizvodnje izdelka (v količini 8.000 kosov). Za izdelavo takšne količine izdelkov je potreben raznovrsten material. Ves potreben material je družba v skupni vrednosti 9.000 EUR kupila pri različnih dobaviteljih, katerim je družba poplačala takoj ob nakupu z nakazilom s svojega transakcijskega računa.

- Družba B15 d.o.o. je zaradi načrtovane proizvodnje potrebovala poseben stroj/napravo. Takoj na začetku leta je družba stroj/napravo v vrednosti 15.000 EUR kupila pri dobavitelju družbi MM d.o.o., kateri je poplačala takoj z nakazilom denarnih sredstev s svojega transakcijskega računa. (Opomba: davščin - npr. davka na dodano vrednost - v zvezi z nakupom stroja/naprave ni.).

- Družba B15 d.o.o. je stroj/napravo uporabljala celo leto, zaradi česar je obračunala t. i. amortizacijo zanj(o) v vrednosti 3.000 EUR. (Opomba: družba uporablja metodo enakomernega časovnega amortiziranja. Letna amortizacijska stopnja za stroj/napravo je $20 \%$.).

- Družba B15 d.o.o. je pri proizvodnji izdelkov ves material porabila. Družba vrednoti svoje zaloge proizvedenih izdelkov po polni stroškovni ceni. ${ }^{5}$ (Opomba: na začetku leta in na koncu leta ni nobenih zalog materiala.).

- Družba B15 d.o.o. je obračunala delo, ki ga je opravila pri njej zaposlena oseba CC v času proizvodnje izdelka (v količini 8.000 kosov). Skupna vrednost obračunanega dela je 8.000 EUR. (Opomba: družba vrednoti svoje zaloge izdelkov po polni stroškovni ceni.) Družba B15 d.o.o. je v zvezi z obračunanim delom izvedla nakazili s svojega transakcijskega računa osebi CC in v državni proračun.

\footnotetext{
5 Obstaja več različnih metod vrednotenja zalog proizvodov oz. učinkov v podjetju. Podrobneje o tem glejte opombo 1.
} 
- Družba B15 d.o.o. je prodala celotno zalogo proizvedenega izdelka kupcu MAKSI d.o.o. Kupec je poplačal opravljen nakup v vrednosti 23.000 EUR takoj z nakazilom na transakcijski račun družbe B15 d.o.o. (Opomba: davščin - npr. davka na dodano vrednost - v zvezi s prodajo proizvedenega izdelka ni.).

- Poslovodstvo družbe B15 d.o.o. je takoj po ustanovitvi odobrilo posojilo v višini 14.000 EUR (nepovezani) družbi KARTA d.o.o. Družba kot posojilodajalec je tudi nakazala posojilo družbi posojilojemalki na njen transakcijski račun. (Opomba: stroškov v zvezi z odobritvijo in nakazilom posojila ni.).

- Družba B15 d.o.o. pred koncem leta obračuna obresti iz naslova danega posojila v skupni vrednosti 2.000 EUR. Obresti je prejela nakazane na svoj transakcijski račun s strani posojilojemalke družbe KARTA d.o.o. (Opomba: stroškov in davščin v zvezi s prejemom nakazila obresti ni.).

\section{Naloga in vprašanja (z.navodili):}

- Izdelajte (poenostavljeno) shemo bilance stanja družbe B15 d.o.o. na začetku leta.

- Izdelajte (poenostavljeno) shemo izkaza poslovnega izida družbe B15 d.o.o. za poslovno leto. (Opomba: davka na dobiček - natančneje: davka od dohodka pravnih oseb - ni.)

- Če ima, katere prihodke in/ali odhodke ima družba? Koliko?

- Kateri je poslovni izid? Kolikšen?

- Izdelajte (poenostavljeno) shemo bilance stanja družbe B15 d.o.o. na koncu leta.

- Katera sredstva (premoženje) in obveznosti (do virov sredstev) ima družba? Koliko?

- Kolikšna je knjigovodska vrednost kapitala družbe?

- Kolikšna je knjigovodska vrednost poslovnega deleža vsakega družbenika?

(Opomba: prikažite iæračune in zapisite odgovore.) 


\section{Rešitev}

Izkaz poslovnega izida

\begin{tabular}{|c|c|c|c|}
\hline & ODHODKI & PRIHODKI & \\
\hline $\begin{array}{l}\text { Odhodki (stroškovna } \\
\text { vrednost prod. proiz.): }\end{array}$ & & 23.000 & $\begin{array}{l}\text { Prihodki od prodaje } \\
\text { proizvodov }\end{array}$ \\
\hline Odhodki (stroški porabljenega & 9.000 & 2.000 & Prihodki (prejete obresti) \\
\hline materiala) & & & \\
\hline Odhodki (stroški amortizacije) & 3.000 & & \\
\hline Odhodki (stroski dela) & 8.000 & & \\
\hline $\begin{array}{r}\text { Odhodki (stroški obresti za izdane } \\
\text { obveznice) }\end{array}$ & 3.000 & & \\
\hline Dobiček $>>$ & 2.000 & & $<<$ Izguba \\
\hline SKUPAJ AKT. STRAN >> & 25.000 & 25.000 & $<<$ SKUPAJ PAS. STRAN \\
\hline
\end{tabular}

Bilanca stanja

\begin{tabular}{|c|c|c|c|}
\hline \multirow{3}{*}{$\begin{array}{r}\text { Osnovna sredstva (stroj) } \\
\text { Finančna naložba (dano } \\
\text { posojilo) }\end{array}$} & SREDSTVA & $\begin{array}{c}\text { OBV. DO } \\
\text { VIROV SRED. }\end{array}$ & \multirow[b]{2}{*}{ Osnovni kapital (vpoklican) } \\
\hline & 12.000 & 10.000 & \\
\hline & 14.000 & & 5.000 Družbenik. $A A(0,5)$ \\
\hline \multirow[t]{3}{*}{ Denarna sredstva (na TR) } & 1.000 & & 5.000 Družbenik BB $(0,5)$ \\
\hline & & 2.000 & \multirow{3}{*}{$\begin{array}{l}<<\text { Posl. izid (dobiček iz IPI) } \\
\text { Obveznost za izdane vredn. } \\
\text { pap. (izdane obveznice) } \\
<<\text { SKUPAI OBV. }\end{array}$} \\
\hline & & 15.000 & \\
\hline SKUPAJ SRED. >> & 27.000 & 27.000 & \\
\hline
\end{tabular}




\section{SKLOP VAJ Z OZNAKO: C}

\section{Vaja C1}

Osebi AA in BB sta na začetku leta ustanovili C1 d.o.o. z 20.000 EUR osnovnega kapitala. Obe sta zagotovili 10.000 EUR denarnega vložka in takoj ob ustanovitvi tudi vplačali denarna sredstva $\mathrm{v}$ celoti na transakcijski račun novoustanovljene družbe. $\mathrm{V}$ družbi C1 d.o.o. se tekom leta zgodita naslednja poslovna dogodka:

- Družba C1 d.o.o. je za izvedbo storitve davčnega svetovanja naročila storitev pregleda pri izkušenem davčnem svetovalcu v vrednosti 4.000 EUR. Družba C1 d.o.o. do konca poslovnega leta ni poplačala kupljene storitve davčnemu svetovalcu. (Opomba: davščin - npr. davka na dodano vrednost - v zvezi z nakupom storitve ni.).

- Družba C1 d.o.o. je opravila storitev davčnega svetovanja v vrednosti 5.000 EUR za naročnika fizično osebo CC. Oseba CC do konca poslovnega leta ni poplačala opravljene storitve. Storitev davčnega svetovanja je bila t. i. intelektualna storitev. (Opomba: davščin - npr. davka na dodano vrednost - v zvezi s prodajo storitve ni.). 
Naloga in vprašanja (žnavodili):

- Izdelajte poenostavljeno shemo bilance stanja družbe C1 d.o.o. na začetku leta.

- Izdelajte poenostavljeno shemo izkaza poslovnega izida družbe C1 d.o.o. za poslovno leto. (Opomba: davka na dobiček - natančneje: davka od dohodka pravnih oseb - ni.)

- Če ima, katere prihodke in/ali odhodke ima družba? Koliko?

- Kateri je poslovni izid? Kolikšen?

- Izdelajte poenostavljeno shemo bilance stanja družbe C1 d.o.o. na koncu leta.

- Katera sredstva (premoženje) in obveznosti (do virov sredstev) ima družba? Koliko?

- Kolikšna je knjigovodska vrednost kapitala družbe?

- Kolikšna je knjigovodska vrednost poslovnega deleža vsakega družbenika?

(Opomba:prikařite iæračune in zapišite odgovore.)

\section{Vsebina / smoter naloge je usvojiti naslednje pojme in problematiko:}

- RI se pripravljajo po načelu nastanka poslovnega dogodka (»ko se dogodek zgodi, ni nujno tudi denarni tok!«)

Rešitev

Izkaz poslovnega izida

\begin{tabular}{|c|c|c|c|}
\hline \multirow[b]{2}{*}{$\begin{array}{r}\text { Odhodki (stroški kupljenih } \\
\text { storitev) }\end{array}$} & ODHODKI & PRIHODKI & \multirow{4}{*}{$\begin{array}{l}\text { Prihodki od prodaje storitev } \\
<<\text { Izguba } \\
<<\text { SKUPAJ PAS. STRAN }\end{array}$} \\
\hline & 4.000 & 5.000 & \\
\hline Dobiček $>>$ & 1.000 & & \\
\hline SKUPAJ AKT. STRAN >> & 5.000 & 5.000 & \\
\hline
\end{tabular}

Bilanca stanja

\begin{tabular}{|c|c|c|c|}
\hline \multirow{6}{*}{$\begin{array}{r}\text { Terjatve do kupca } \\
\text { Denarna sredstva (na TR) }\end{array}$} & SREDSTVA & $\begin{array}{c}\text { OBV. DO } \\
\text { VIROV SRED. }\end{array}$ & \multirow[b]{2}{*}{ Osnovni kapital (vpoklican) } \\
\hline & \multirow{5}{*}{$\begin{array}{c}5.000 \\
20.000\end{array}$} & \multirow[t]{3}{*}{20.000} & \\
\hline & & & 10.000 Drušbenik. $A A(0,5)$ \\
\hline & & & 10.000 Druq̌benik BB $(0,5)$ \\
\hline & & 1.000 & \multirow{3}{*}{$\begin{array}{l}<<\text { Posl. izid (dobiček iz IPI) } \\
\text { Dolg (obv.) do dobavitelja } \\
<<\text { SKUPAJ OBV. }\end{array}$} \\
\hline & & 4.000 & \\
\hline SKUPAJ SRED. >> & 25.000 & 25.000 & \\
\hline
\end{tabular}




\section{Vaja C2}

Osebi AA in BB sta na začetku leta ustanovili C2 d.o.o. z 20.000 EUR osnovnega kapitala. Obe sta zagotovili 10.000 EUR denarnega vložka in takoj ob ustanovitvi tudi vplačali denarna sredstva $\mathrm{v}$ celoti na transakcijski račun novoustanovljene družbe.

V družbi C2 d.o.o. se tekom leta zgodita naslednja poslovna dogodka:

- Družba C2 d.o.o. je za izvedbo storitve davčnega svetovanja naročila storitev pregleda pri izkušenem davčnem svetovalcu v vrednosti 4.000 EUR. Družba C2 d.o.o. je do konca poslovnega leta poplačala polovico zneska za kupljeno storitev davčnemu svetovalcu z nakazilom denarnih sredstev s svojega transakcijskega računa. (Opomba: davščin - npr. davka na dodano vrednost $-\mathrm{v}$ zvezi z nakupom storitve ni.).

- Družba C2 d.o.o. je opravila storitev davčnega svetovanja v vrednosti 5.000 EUR za naročnika fizično osebo CC. Oseba CC do konca poslovnega leta poplačala štiri petine zaračunanega zneska za opravljeno storitev z nakazilom denarnih sredstev na transakcijski račun družbe C2 d.o.o. Storitev davčnega svetovanja je bila t. i. intelektualna storitev. (Opomba: davščin - npr. davka na dodano vrednost $-\mathrm{v}$ zvezi s prodajo storitve ni.).

Naloga in uprašanja (z navodili):

- Izdelajte poenostavljeno shemo bilance stanja družbe C2 d.o.o. na začetku leta.

- Izdelajte poenostavljeno shemo izkaza poslovnega izida družbe C2 d.o.o. za poslovno leto. (Opomba: davka na dobiček - natančneje: davka od dohodka pravnih oseb - ni.)

- Če ima, katere prihodke in/ali odhodke ima družba? Koliko?

- Kateri je poslovni izid? Kolikšen?

- Izdelajte poenostavljeno shemo bilance stanja družbe C2 d.o.o. na koncu leta.

- Katera sredstva (premoženje) in obveznosti (do virov sredstev) ima družba? Koliko?

- Kolikšna je knjigovodska vrednost kapitala družbe?

- Kolikšna je knjigovodska vrednost poslovnega deleža vsakega družbenika?

(Opomba: prikažite iz̧račune in zapišite odgovore.) 


\section{Rešitev}

Izkaz poslovnega izida

\begin{tabular}{|c|c|c|c|}
\hline & ODHODKI & PRIHODKI & \\
\hline $\begin{array}{r}\text { Odhodki (stroški kupljenih } \\
\text { storitev) }\end{array}$ & 4.000 & 5.000 & Prihodki od prodaje storitve \\
\hline Dobiček $>>$ & 1.000 & & $<<$ Izguba \\
\hline SKUPAJ AKT. STRAN >> & 5.000 & 5.000 & $<<$ SKUPAJ PAS. STRAN \\
\hline
\end{tabular}

Bilanca stanja

\begin{tabular}{|c|c|c|c|}
\hline \multirow{6}{*}{$\begin{array}{r}\text { Terjatve do kupca } \\
\text { Denarna sredstva (na TR) }\end{array}$} & SREDSTVA & OBV. DO & \multirow[b]{2}{*}{ Osnovni kapital (vpoklican) } \\
\hline & \multirow{5}{*}{$\begin{array}{c}1.000 \\
22.000\end{array}$} & \multirow[t]{3}{*}{20.000} & \\
\hline & & & 10.000 Družbenik $A A(0,5)$ \\
\hline & & & 10.000 Družbenik $B B(0,5)$ \\
\hline & & 1.000 & \multirow{3}{*}{$\begin{array}{l}<<\text { Posl. izid (dobiček iz IPI) } \\
\text { Dolg (obv.) do dobavitelja } \\
<<\text { SKUPAJ OBV. }\end{array}$} \\
\hline & & 2.000 & \\
\hline SKUPAJ SRED. >> & 23.000 & 23.000 & \\
\hline
\end{tabular}

Vaja C3

Osebi AA in BB sta na začetku leta ustanovili C3 d.o.o. z 20.000 EUR osnovnega kapitala. Obe sta zagotovili 10.000 EUR denarnega vložka in takoj ob ustanovitvi tudi vplačali denarna sredstva $\mathrm{v}$ celoti na transakcijski račun novoustanovljene družbe.

V družbi C3 d.o.o. se tekom leta zgodijo naslednji poslovni dogodki:

- Družba C3 d.o.o. je zaradi načrtovanega opravljanja storitev pravnega svetovanja potrebovala več računalniških in drugih pripomočkov (računalnik, tiskalnik, kopirni stroj itd.). Takoj na začetku leta je družba pripomočke v vrednosti 10.000 EUR kupila pri dobavitelju družbi PP d.o.o. Družba C3 d.o.o. je do konca poslovnega leta poplačala tri četrtine dobavitelju družbi PP d.o.o. z nakazilom denarnih sredstev s svojega transakcijskega računa. (Opomba: davščin - npr. davka na dodano vrednost - v zvezi z nakupom pripomočkov ni.).

- Družba C3 d.o.o. je pripomočke uporabljala celo leto, zaradi česar je obračunala t. i. amortizacijo zanje v vrednosti 5.000 EUR. (Opomba: družba uporablja 
metodo enakomernega časovnega amortiziranja. Letna amortizacijska stopnja za računalniške pripomočke je $50 \%$.).

- Poslovodstvo družbe C3 d.o.o. je ocenilo, da potrebuje dodatna denarna sredstva za svoje poslovanje. Družba je zato takoj po ustanovitvi najela 10.000 EUR posojila pri (nepovezani) družbi POSOJA d.o.o. Posojilodajalec je skladno s posojilno pogodbo nakazal prvo tranšo posojila družbi na njen transakcijski račun v vrednosti 5.000 EUR. Druga tranša bo skladno s posojilno pogodbo nakazana po enem letu od sklenitve posojilne pogodbe. (Opomba: stroškov najema posojila ni.).

- Družba C3 d.o.o. pred koncem leta prejme obračun obresti iz naslova najetega posojila v skupni vrednosti 1.000 EUR. Obresti družba do konca poslovnega leta ne nakaže družbi POSOJA d.o.o. (Opomba: stroškov in davščin v zvezi z nakazilom obresti ni.).

- Družba C3 d.o.o. je opravila storitev pravnega svetovanja (na področju korporacijskega in davčnega prava) v vrednosti 15.000 EUR za naročnika fizično osebo CC. Oseba CC je do konca poslovnega leta poplačala dve tretjini zaračunanega zneska za opravljeno storitev z nakazilom denarnih sredstev na transakcijski račun družbe C3 d.o.o. Storitev pravnega svetovanja je bila t. i. intelektualna storitev. (Opomba: davščin - npr. davka na dodano vrednost - v zvezi s prodajo storitve ni.).

- Družba C3 d.o.o. je obračunala delo, ki ga je opravila pri njej zaposlena oseba DD v času izvajanja storitve. Skupna vrednost obračunanega dela je 10.000 EUR. Družba C3 d.o.o. je v zvezi z obračunanim delom izvedla nakazili s svojega transakcijskega računa osebi DD in v državni proračun.

\section{Naloga in vprašanja (z navodili):}

- Izdelajte poenostavljeno shemo bilance stanja družbe C3 d.o.o. na začetku leta.

- Izdelajte poenostavljeno shemo izkaza poslovnega izida družbe C3 d.o.o. za poslovno leto. (Opomba: davka na dobiček - natančneje: davka od dohodka pravnih oseb - ni.)

- Če ima, katere prihodke in/ali odhodke ima družba? Koliko?

- Kateri je poslovni izid? Kolikšen?

- Izdelajte poenostavljeno shemo bilance stanja družbe C3 d.o.o. na koncu leta.

- Katera sredstva (premoženje) in obveznosti (do virov sredstev) ima družba? Koliko?

- Kolikšna je knjigovodska vrednost kapitala družbe? 
- Kolikšna je knjigovodska vrednost poslovnega deleža vsakega družbenika?

(Opomba: prikažite izračune in zapišite odgovore.)

\section{Vsebina / smoter naloge je usvojiti naslednje pojme in problematiko:}

- Poznamo poslovne in finančne (oboji so redni) in druge (izredne) prihodke in odhodke.

\section{Rešitev}

\section{Izkaz poslovnega izida}

\begin{tabular}{|c|c|c|c|}
\hline & ODHODKI & PRIHODKI & \\
\hline $\begin{array}{r}\text { Odhodki (stroški } \\
\text { amortizacije) }\end{array}$ & 5.000 & 15.000 & Prihodki od prodaje storitev \\
\hline Odhodki (stroški dela/plač) & 10.000 & & \\
\hline $\begin{array}{r}\text { Odhodki (stroški obresti } \\
\text { zaradi fin.) }\end{array}$ & 1.000 & & \\
\hline Dobiček $>>$ & & 1.000 & $<<$ Izguba \\
\hline SKUPAJ AKT. STRAN >> & 16.000 & 16.000 & $<<$ SKUPAJ PAS. STRAN \\
\hline
\end{tabular}

Bilanca stanja

\begin{tabular}{|c|c|c|c|}
\hline \multirow{3}{*}{$\begin{array}{r}\text { Osnovna sredstva (rač. prip.) } \\
\text { Terjatve do kupca }\end{array}$} & SREDSTVA & $\begin{array}{l}\text { OBV. DO } \\
\text { VIROV SRED. }\end{array}$ & \multirow[b]{2}{*}{ Osnovni kapital (vpoklican) } \\
\hline & \multirow{2}{*}{$\begin{array}{l}5.000 \\
5.000\end{array}$} & \multirow[t]{3}{*}{20.000} & \\
\hline & & & 10.000 Drušbenik $A A(0,5)$ \\
\hline Terjatve za najeta posojila & 5.000 & & 10.000 Družbenik. BB $(0,5)$ \\
\hline \multirow[t]{2}{*}{ Denarna sredstva (na TR) } & \multirow[t]{2}{*}{17.500} & -1.000 & \multirow{3}{*}{$\begin{array}{l}<<\text { Posl. izid (izguba iz IPI) } \\
\text { Dolgovi za najeto posojilo } \\
\text { (POSOJA d.o.o.) } \\
\text { Dolg (obv.) za plačilo obrest } \\
\text { za naj. pos. } \\
\text { Dolg (obv.) do dobavitelja } \\
<<\text { SKUPAJ OBV. }\end{array}$} \\
\hline & & $\begin{array}{l}10.000 \\
1.000 \\
2.500\end{array}$ & \\
\hline SKUPAJ SRED. >> & 32.500 & 32.500 & \\
\hline
\end{tabular}

\section{Vaja C4}

Osebi AA in BB sta na začetku leta ustanovili C4 d.o.o. z 20.000 EUR osnovnega kapitala. Obe sta zagotovili 10.000 EUR denarnega vložka in takoj ob ustanovitvi tudi vplačali denarna sredstva $\mathrm{v}$ celoti na transakcijski račun novoustanovljene družbe. 
V družbi C4 d.o.o. se tekom leta zgodijo naslednji poslovni dogodki:

- Družba C4 d.o.o. je na začetku leta izdala obveznice v skupni vrednosti 10.000 EUR, ki jih uspešno prodala. Prodane obveznice je plačal kupec banka BANKA d.d. takoj z nakazilom denarnih sredstev na transakcijski račun družbe C4 d.o.o. (Opomba: stroškov v zvezi z izdajo in prodajo obveznic ni.).

- Družba C4 d.o.o. pred koncem leta obračuna (kuponske) obresti iz naslova izdane obveznice v skupni vrednosti 2.000 EUR. Družba C4 d.o.o. je do konca poslovnega leta poplačala polovico zneska obračunih obresti z nakazilom denarnih sredstev na transakcijski račun banke BANKA d.d. (Opomba: stroškov in davščin $\mathrm{v}$ zvezi z nakazilom obresti ni.).

- Poslovodstvo družbe C4 d.o.o. je takoj po ustanovitvi odobrilo posojilo v višini 30.000 EUR (nepovezani) družbi KARTA d.o.o. Družba kot posojilodajalec je skladno s posojilno pogodbo nakazala prvo tranšo posojila $\mathrm{v}$ znesku 15.000 EUR družbi posojilojemalki na njen transakcijski račun. (Opomba: stroškov v zvezi z odobritvijo in nakazilom posojila ni.).

- Družba C4 d.o.o. pred koncem leta obračuna obresti iz naslova danega posojila v skupni vrednosti 3.000 EUR. Obresti do konca poslovnega leta ni prejela nakazane na svoj transakcijski račun s strani posojilojemalke družbe KARTA d.o.o. (Opomba: stroškov in davščin v zvezi s prejemom nakazila obresti ni.).

- Družba C4 d.o.o. je za izvedbo storitve dajanja posojila naročila storitev bonitetnega pregleda možnega posojilojemalca pri izkušenem analitiku $\mathrm{v}$ vrednosti 2.000 EUR. Družba C4 d.o.o. je do konca poslovnega leta poplačala polovico zneska kupljene storitve izkušenega analitika z nakazilom denarnih sredstev s svojega transakcijskega računa. (Opomba: davščin - npr. davka na dodano vrednost - v zvezi z nakupom storitve ni.).

- Družba C4 d.o.o. je obračunala delo, ki ga je opravila pri njej zaposlena oseba CC v času izvajanja storitve. Skupna vrednost obračunanega dela je 1.000 EUR. Družba C4 d.o.o. je v zvezi z obračunanim delom izvedla nakazili s svojega transakcijskega računa osebi CC in v državni proračun.

\section{Naloga in vprašanja (z, navodili):}

- Izdelajte poenostavljeno shemo bilance stanja družbe C4 d.o.o. na začetku leta.

- Izdelajte poenostavljeno shemo izkaza poslovnega izida družbe C4 d.o.o. za poslovno leto. (Opomba: davka na dobiček - natančneje: davka od dohodka pravnih oseb - ni.)

- Če ima, katere prihodke in/ali odhodke ima družba? Koliko? 
- Kateri je poslovni izid? Kolikšen?

- Izdelajte poenostavljeno shemo bilance stanja družbe C4 d.o.o. na koncu leta.

- Katera sredstva (premoženje) in obveznosti (do virov sredstev) ima družba? Koliko?

- Kolikšna je knjigovodska vrednost kapitala družbe?

- Kolikšna je knjigovodska vrednost poslovnega deleža vsakega družbenika?

(Opomba: prikažite izračune in zapišite odgovore.)

\section{Rešitev}

Izkaz poslovnega izida

\begin{tabular}{|c|c|c|c|}
\hline & ODHODKI & PRIHODKI & \\
\hline $\begin{array}{r}\text { Odhodki (stroški kupljenih } \\
\text { storitev) }\end{array}$ & 2.000 & 3.000 & $\begin{array}{l}\text { Prihodki od prejetih obresti } \\
\text { (za dano posojilo) }\end{array}$ \\
\hline Odhodki (stroški dela/plač) & 1.000 & & \\
\hline $\begin{array}{r}\text { Odhodki (stroški obresti } \\
\text { zaradi fin.) }\end{array}$ & 2.000 & & \\
\hline Dobiček >> & & 2.000 & $<<$ Izguba \\
\hline SKUPAJ AKT. STRAN >> & 5.000 & 5.000 & $<<$ SKUPAJ PAS. STRAN \\
\hline
\end{tabular}

Bilanca stanja

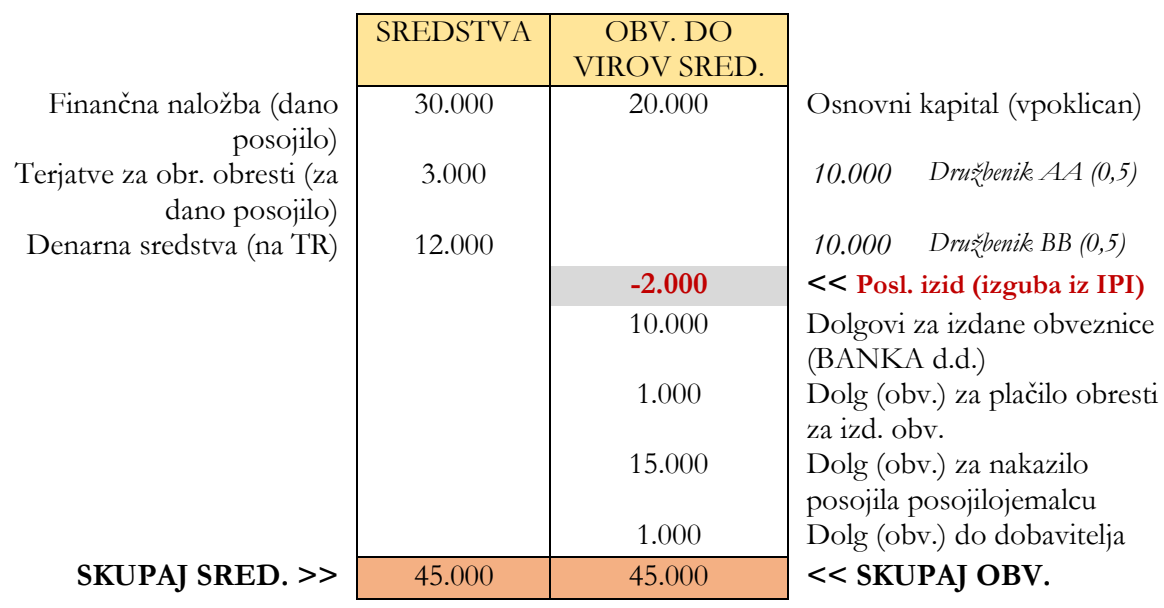




\section{Vaja C5}

Osebi AA in BB sta na začetku leta ustanovili C5 d.o.o. z 20.000 EUR osnovnega kapitala. Obe sta zagotovili 10.000 EUR denarnega vložka in takoj ob ustanovitvi tudi vplačali denarna sredstva $\mathrm{v}$ celoti na transakcijski račun novoustanovljene družbe.

V družbi C5 d.o.o. se tekom leta zgodita naslednja poslovna dogodka:

- Družba C5 d.o.o. je načrtovala začetek proizvodnje izdelka, vendar na začetku leta ni imela potrebnega materiala, da bi lahko začela s proizvodnjo. Ker je sklenila prodajno pogodbo s kupcem MINI d.o.o., da bo zagotovila 2.000 kosov izdelka do konca leta, je poiskala in naročila enakovrsten izdelek na tujem trgu. Družba je kupila potrebno količino izdelka v skupni vrednosti 16.000 EUR pri dobavitelju QQ d.o.o. Družba je do konca poslovnega leta poplačala tri četrtine zneska dobavitelju z nakazilom denarnih sredstev s svojega transakcijskega računa. (Opomba: stroškov in davščin v zvezi z nakupom izdelkov ni.).

- Družba C5 d.o.o. je prodala celotno zalogo proizvedenega izdelka kupcu MINI d.o.o. Kupec je do konca poslovnega leta poplačal 10.000 EUR, kar je polovico zneska opravljenega nakupa v skupni vrednosti 20.000 EUR z nakazilom denarnih sredstev na transakcijski račun družbe C5 d.o.o. (Opomba: davščin npr. davka na dodano vrednost - v zvezi s prodajo proizvedenega izdelka ni.).

\section{Naloga in vprašanja (z.navodili):}

- Izdelajte poenostavljeno shemo bilance stanja družbe C5 d.o.o. na začetku leta.

- Izdelajte poenostavljeno shemo izkaza poslovnega izida družbe C5 d.o.o. za poslovno leto. (Opomba: davka na dobiček - natančneje: davka od dohodka pravnih oseb - ni.)

- Če ima, katere prihodke in/ali odhodke ima družba? Koliko?

- Kateri je poslovni izid? Kolikšen?

- Izdelajte poenostavljeno shemo bilance stanja družbe C5 d.o.o. na koncu leta.

- Katera sredstva (premoženje) in obveznosti (do virov sredstev) ima družba? Koliko?

- Kolikšna je knjigovodska vrednost kapitala družbe?

- Kolikšna je knjigovodska vrednost poslovnega deleža vsakega družbenika?

(Opomba: prikažite izračune in zapišite odgovore.) 


\section{Rešitev}

Izkaz poslovnega izida

\begin{tabular}{|c|c|c|c|}
\hline \multirow{3}{*}{$\begin{array}{r}\text { Odhodki (stroškovna } \\
\text { vrednost prod. proiz.) } \\
\text { Dobiček >> }\end{array}$} & ODHODKI & PRIHODKI & \multirow{4}{*}{$\begin{array}{l}\text { Prihodki od prodaje } \\
\text { proizvodov } \\
<<\text { Izguba } \\
<<\text { SKUPAJ PAS. STRAN }\end{array}$} \\
\hline & 16.000 & 20.000 & \\
\hline & 4.000 & & \\
\hline KUPAJ AKT. STRAN >> & 20.000 & 20.000 & \\
\hline
\end{tabular}

Bilanca stanja

\begin{tabular}{|c|c|c|c|}
\hline \multirow{6}{*}{$\begin{array}{r}\text { Terjatve do kupca } \\
\text { Denarna sredstva (na TR) }\end{array}$} & SREDSTVA & $\begin{array}{c}\text { OBV. DO } \\
\text { VIROV SRED. }\end{array}$ & \multirow[b]{2}{*}{ Osnovni kapital (vpoklican) } \\
\hline & 10.000 & \multirow[t]{3}{*}{20.000} & \\
\hline & \multirow[t]{4}{*}{18.000} & & 10.000 Družbenik $A A(0,5)$ \\
\hline & & & 10.000 Drǔ̌benik BB $(0,5)$ \\
\hline & & 4.000 & \multirow{3}{*}{$\begin{array}{l}<<\text { Posl. izid (dobiček iz IPI) } \\
\text { Dolg (obv.) do dobavitelja } \\
<<\text { SKUPAJ OBV. }\end{array}$} \\
\hline & & 4.000 & \\
\hline SKUPAJ SRED. $>>$ & 28.000 & 28.000 & \\
\hline
\end{tabular}

\section{Vaja C6}

Osebi AA in BB sta na začetku leta ustanovili C6 d.o.o. z 20.000 EUR osnovnega kapitala. Obe sta zagotovili 10.000 EUR denarnega vložka in takoj ob ustanovitvi tudi vplačali denarna sredstva $\mathrm{v}$ celoti na transakcijski račun novoustanovljene družbe.

V družbi C6 d.o.o. se tekom leta zgodijo naslednji poslovni dogodki:

- Družba C6 d.o.o. je načrtovala začetek proizvodnje izdelka (v količini 5.000 kosov). Za izdelavo takšne količine izdelkov je potreben raznovrsten material. Ves potreben material je družba v skupni vrednosti 15.000 EUR kupila pri različnih dobaviteljih. Družba C6 d.o.o. je do konca poslovnega leta poplačala dve tretjini zneska za nabavljen material z nakazilom denarnih sredstev s svojega transakcijskega računa.

- Družba C6 d.o.o. je pri proizvodnji izdelkov ves material porabila. Družba vrednoti svoje zaloge proizvedenih izdelkov po polni stroškovni ceni. ${ }^{6}$ (Opomba: na začetku leta in na koncu leta ni nobenih zalog materiala.).

\footnotetext{
${ }^{6}$ Obstaja več različnih metod vrednotenja zalog proizvodov oz. učinkov v podjetju. Podrobneje o tem glejte opombo 1.
} 
- Družba C6 d.o.o. je obračunala delo, ki ga je opravila pri njej zaposlena oseba CC v času proizvodnje izdelka (v količini 5.000 kosov). Skupna vrednost obračunanega dela je 9.000 EUR. (Opomba: družba vrednoti svoje zaloge izdelkov po polni stroškovni ceni.) Družba C6 d.o.o. je v zvezi z obračunanim delom izvedla nakazili s svojega transakcijskega računa osebi CC in v državni proračun.

\section{Naloga in uprašanja (z. navodili):}

- Izdelajte poenostavljeno shemo bilance stanja družbe C6 d.o.o. na začetku leta.

- Izdelajte poenostavljeno shemo izkaza poslovnega izida družbe C6 d.o.o. za poslovno leto. (Opomba: davka na dobiček - natančneje: davka od dohodka pravnih oseb - ni.)

- Če ima, katere prihodke in/ali odhodke ima družba? Koliko?

- Kateri je poslovni izid? Kolikšen?

- Izdelajte poenostavljeno shemo bilance stanja družbe C6 d.o.o. na koncu leta.

- Katera sredstva (premoženje) in obveznosti (do virov sredstev) ima družba? Koliko?

- Kolikšna je knjigovodska vrednost kapitala družbe?

- Kolikšna je knjigovodska vrednost poslovnega deleža vsakega družbenika?

(Opomba: prikažite izračune in zapišite odgovore.)

Poenostavljena (prilagojena) rešitev

Izkaz poslovnega izida

\begin{tabular}{|c|c|c|c|}
\hline \multirow[b]{2}{*}{$\begin{array}{r}\text { Odhodki (stroškovna vrednost } \\
\text { prod. proiz.) }\end{array}$} & ODHODKI & PRIHODKI & \multirow{3}{*}{$\begin{array}{l}\text { Prihodki od prodaje } \\
\text { proizvodov } \\
<<\text { Izguba }\end{array}$} \\
\hline & & & \\
\hline Dobiček >> & 0 & & \\
\hline SKUPAJ AKT. STRAN $>>$ & 0 & 0 & $<<$ SKUPAJ PAS. STRAN \\
\hline
\end{tabular}

Opomba: Poenostavljena rešitev je rešitev, ki ni v popolnosti skladna s predpisano shemo izkaza poslovnega izida v 2. odstavku 66. člena ZGD-1. Podrobneje o tem glejte obrazložitev k rešitvi pri vaji B11.7

\footnotetext{
${ }^{7}$ Obstaja več različnih metod vrednotenja zalog proizvodov oz. učinkov v podjetju. Podrobneje o tem glejte opombo 1.
} 
Vmesno stanje (po 1. poslovnem dogodku):

Bilanca stanja

\begin{tabular}{|c|c|c|c|}
\hline \multirow[b]{2}{*}{ Zaloga materiala } & SREDSTVA & $\begin{array}{c}\text { OBV. DO } \\
\text { VIROV SRED.V }\end{array}$ & \multirow{4}{*}{$\begin{array}{l}\text { Osnovni kapital } \\
\text { (vpoklican) } \\
\text { Dolg do dobavitelja } \\
\text { materiala }\end{array}$} \\
\hline & 15.000 & 20.000 & \\
\hline $\begin{array}{l}\text { Zaloga dokončanih } \\
\text { proizvodov }\end{array}$ & 0 & 5.000 & \\
\hline narna sredstva (na TR) & 10.000 & & \\
\hline SKUPAJ SRED. >> & 25.000 & 25.000 & $<<$ SKUPAJ OBV \\
\hline
\end{tabular}

Vmesno stanje (po 2. poslovnem dogodku):

Bilanca stanja

\begin{tabular}{|c|c|c|c|}
\hline & SREDSTVA & $\begin{array}{c}\text { OBV. DO } \\
\text { VIROV SRED. }\end{array}$ & \\
\hline Zaloga materiala & 0 & 20.000 & Osnovni kapital (vpoklican) \\
\hline $\begin{array}{r}\text { Zaloga dokončanih } \\
\text { proizvodov }\end{array}$ & 15.000 & 5.000 & $\begin{array}{l}\text { Dolg do dobavitelja } \\
\text { materiala }\end{array}$ \\
\hline Denarna sredstva (na TR) & 10.000 & & \\
\hline SKUPAJ SRED. >> & 25.000 & 25.000 & $<<$ SKUPAJ OBV. \\
\hline
\end{tabular}

Opomba: poenostavljeno, zaradi vrednotenja zalog proizvodov v podjetju po polni stroškovni ceni, se vsi stroški - v tej nalogi stroški porabljenega materiala (iz zaloge materiala) - pripišejo (»prenesejo«) na vrednost zaloge dokončanih proizvodov. Ker so stroški "preneseni« na vrednost zaloge dokončanih proizvodov, še niso preoblikovani $\mathrm{v}$ odhodke. To se praviloma zgodi šele ob opravljeni prodaji proizvodov kupcu le-teh.

Končno stanje (po 3. poslovnem dogodku):

Bilanca stanja

\begin{tabular}{|c|c|c|c|}
\hline & SREDSTVA & OBV. DO & \\
\hline $\begin{array}{l}\text { Zaloga dokončanih } \\
\text { proizvodov }\end{array}$ & 24.000 & 20.000 & Osnovni kapital (vpoklican) \\
\hline \multirow[t]{3}{*}{ Denarna sredstva (na TR) } & \multirow[t]{3}{*}{1.000} & & $\begin{array}{l}\text { 10.000 Družbenik } A A(0,5) \\
\text { 10.000 Drušbenik. } B B(0,5)\end{array}$ \\
\hline & & 0 & $<<$ Posl. izid iz IPI \\
\hline & & 5.000 & Dolg (obv.) do dobavitelja \\
\hline SKUPAI SRED. >> & 25.000 & 25.000 & $<<$ SKUPAI OBV. \\
\hline
\end{tabular}


Opomba: poenostavljeno, zaradi vrednotenja zalog proizvodov v podjetju po polni stroškoovni ceni, se vsi stroški - v tej nalogi stroški obračunanega dela - pripišejo (»prenesejo«) na vrednost zaloge dokončanih proizvodov. Ker so stroški »preneseni« na vrednost zaloge dokončanih proizvodov, še niso preoblikovani v odhodke. To se praviloma zgodi šele ob opravljeni prodaji proizvodov kupcu le-teh.

Podrobnejšo obrazložitev glejte $\mathrm{k}$ prikazani rešitvi pri vaji B11. ${ }^{8}$

\section{Vaja C7}

Osebi AA in BB sta na začetku leta ustanovili C7 d.o.o. z 20.000 EUR osnovnega kapitala. Obe sta zagotovili 10.000 EUR denarnega vložka in takoj ob ustanovitvi tudi vplačali denarna sredstva $\mathrm{v}$ celoti na transakcijski račun novoustanovljene družbe.

V družbi C7 d.o.o. se tekom leta zgodijo naslednji poslovni dogodki:

- Družba C7 d.o.o. na začetku leta najame posojilo pri drugi (nepovezani) družbi POSOJA d.o.o. v skupni vrednosti 10.000 EUR. Posojilodajalec je skladno s posojilno pogodbo nakazal prvo tranšo posojila družbi na njen transakcijski račun v vrednosti 5.000 EUR. Druga tranša bo skladno s posojilno pogodbo nakazana po enem letu od sklenitve posojilne pogodbe. (Opomba: $v$ trenutku najema posojila ni nobenih obresti, ki bi jih moral poravnati posojilojemalec. Stroškov najema posojila ni.).

- Družba C7 d.o.o. pred koncem leta prejme obračun obresti za najeto posojilo od družbe POSOJA d.o.o. v skupni vrednosti 1.000 EUR. Obresti družba do konca poslovnega leta ne nakaže družbi POSOJA d.o.o. (Opomba: stroškov in davščin v zvezi z nakazilom obresti ni.).

- Družba C7 d.o.o. je načrtovala začetek proizvodnje izdelka (v količini 10.000 kosov). Za izdelavo takšne količine izdelkov je potreben raznovrsten material. Ves potreben material je družba v skupni vrednosti 10.000 EUR kupila pri različnih dobaviteljih. Družba C7 d.o.o. je do konca poslovnega leta poplačala stiri petine zneska za nabavljen material z nakazilom denarnih sredstev s svojega transakcijskega računa.

\footnotetext{
8 Obstaja več različnih metod vrednotenja zalog proizvodov oz. učinkov v podjetju. Podrobneje o tem glejte opombo 1.
} 
- Družba C7 d.o.o. je pri proizvodnji izdelkov ves material porabila. Družba vrednoti svoje zaloge proizvedenih izdelkov po polni stroškovni ceni. ${ }^{9}$ (Opomba: na začetku leta in na koncu leta ni nobenih zalog materiala.).

- Družba C7 d.o.o. je za opravilo proizvodnje izdelkov naročila več storitev opravljanja raznovrstnih del pri več izkušenih proizvajalcih podobnih izdelkov (kot podizvajalcih) v skupni vrednosti 8.000 EUR. Družba C7 d.o.o. je do konca poslovnega leta poplačala tri četrtine zneska kupljenih storitev pri izkušenih proizvajalcih $\mathrm{z}$ nakazili denarnih sredstev $\mathrm{s}$ svojega transakcijskega računa. (Opomba: davščin - npr. davka na dodano vrednost $-\mathrm{v}$ zvezi z nakupom storitev ni.).

- Družba C7 d.o.o. je na koncu leta prodala celotno zalogo proizvedenih izdelkov kupcu MAKSI d.o.o. Kupec je poplačal tri četrtine zneska kupljenih proizvedenih izdelkov v skupni vrednosti 20.000 EUR takoj z nakazilom denarnih sredstev na transakcijski račun družbe C7 d.o.o. (Opomba: davščin - npr. davka na dodano vrednost $-\mathrm{v}$ zvezi s prodajo proizvedenih izdelkov ni.).

- Družba C7 d.o.o. je na začetku leta kupila delnice druge družbe ZZ d.d. v skupni vrednosti 10.000 EUR. Kupljene delnice je plačala takoj z nakazilom denarnih sredstev s transakcijskega računa družbe prodajalcu delnic. (Opomba: stroškov $\mathrm{v}$ zvezi s prenosom delnic ni.).

- Družba C7 d.o.o. je pred koncem leta prejela upravičenje do dividend družbe ZZ d.d. v skupni vrednosti 1.000 EUR. Družba ZZ d.o.o. do konca leta ni izvršila nakazila na transakcijski račun družbe $\mathrm{C} 7$ d.o.o. (Opomba: davščin v zvezi z nakazilom dividend oz. potrebe po akontaciji davščin ni.).

Naloga in uprašanja (z navodili):

- Izdelajte poenostavljeno shemo bilance stanja družbe C7 d.o.o. na začetku leta.

- Izdelajte poenostavljeno shemo izkaza poslovnega izida družbe C7 d.o.o. za poslovno leto. (Opomba: davka na dobiček - natančneje: davka od dohodka pravnih oseb - ni.)

- Če ima, katere prihodke in/ali odhodke ima družba? Koliko?

- Kateri je poslovni izid? Kolikšen?

- Izdelajte poenostavljeno shemo bilance stanja družbe C7 d.o.o. na koncu leta.

- Katera sredstva (premoženje) in obveznosti (do virov sredstev) ima družba? Koliko?

\footnotetext{
9 Obstaja več različnih metod vrednotenja zalog proizvodov oz. učinkov v podjetju. Podrobneje o tem glejte opombo 1.
} 
- Kolikšna je knjigovodska vrednost kapitala družbe?

- Kolikšna je knjigovodska vrednost poslovnega deleža vsakega družbenika?

(Opomba: prikažite izračune in zapisite odgovore.)

\section{Rešitev}

Izkaz poslovnega izida

\begin{tabular}{|c|c|c|c|}
\hline & ODHODKI & PRIHODKI & \\
\hline $\begin{array}{l}\text { Odhodki (stroškovna } \\
\text { vrednost prod. proiz.): }\end{array}$ & & 20.000 & $\begin{array}{l}\text { Prihodki od prodaje } \\
\text { proizvodov }\end{array}$ \\
\hline $\begin{array}{r}\text { Odhodki (stroški porabljenega } \\
\text { materiala) }\end{array}$ & 10.000 & 1.000 & Prihodki (prejete dividende) \\
\hline $\begin{array}{r}\text { Odhodki (stroški kupljenih } \\
\text { storitev) }\end{array}$ & 8.000 & & \\
\hline $\begin{array}{r}\text { storttev) } \\
\text { Odhodki (stroški obresti zaradi } \\
\text { fin.) }\end{array}$ & 1.000 & & \\
\hline Dobiček >> & 2.000 & & $<<$ Izguba \\
\hline SKUPAJ AKT. STRAN >> & 21.000 & 21.000 & $<<$ SKUPAJ PAS. STRAN \\
\hline
\end{tabular}

Bilanca stanja

\begin{tabular}{|c|c|c|c|}
\hline & SREDSTVA & $\begin{array}{c}\text { OBV. DO } \\
\text { VIROV SRED. }\end{array}$ & \\
\hline $\begin{array}{r}\text { Finančna naložba (kupljene } \\
\text { delnice) }\end{array}$ & 10.000 & 20.000 & $\begin{array}{l}\text { Osnovni kapital (vpoklican) } \\
10.000 \text { Dru乏̌benik. } A A(0,5)\end{array}$ \\
\hline Terjatev za dividende & 1.000 & & 10.000 Družbenik BB $(0,5)$ \\
\hline Terjatev do kupca & 5.000 & 2.000 & $<<$ Posl. izid (dobiček iz IPI) \\
\hline Terjatve za najeta posojila & 5.000 & 10.000 & $\begin{array}{l}\text { Dolgovi za najeto posojilo } \\
\text { (POSOJA d.o.o.) }\end{array}$ \\
\hline Denarna sredstva (na TR) & 16.000 & $\begin{array}{l}1.000 \\
4.000\end{array}$ & $\begin{array}{l}\text { Dolg (obv.) za plačilo obresti } \\
\text { za naj. pos. } \\
\text { Dolg (obv.) do dobavitelia }\end{array}$ \\
\hline SKUPAJ SRED. >> & 37.000 & 37.000 & << SKUPAJ OBV. \\
\hline
\end{tabular}

\section{Vaja C8}

Osebi AA in BB sta na začetku leta ustanovili C8 d.o.o. z 20.000 EUR osnovnega kapitala. Obe sta zagotovili 10.000 EUR denarnega vložka in takoj ob ustanovitvi tudi vplačali denarna sredstva $\mathrm{v}$ celoti na transakcijski račun novoustanovljene družbe. 
V družbi C8 d.o.o. se tekom leta zgodijo naslednji poslovni dogodki:

- Družba C8 d.o.o. je na začetku leta izdala obveznice v skupni vrednosti 10.000 EUR, ki jih uspešno prodala. Prodane obveznice je plačal kupec banka BANKA d. d. takoj z nakazilom denarnih sredstev na transakcijski račun družbe C8 d.o.o. (Opomba: stroškov v zvezi z izdajo in prodajo obveznic ni.).

- Družba C8 d.o.o. je pred koncem leta obračunala (kuponske) obresti iz naslova izdane obveznice v skupni vrednosti 2.000 EUR. Družba C8 d.o.o. je do konca poslovnega leta polovico zneska obresti poplačala z nakazilom denarnih sredstev na transakcijski račun banke BANKA d.d. (Opomba: stroškov in davščin v zvezi z nakazilom obresti ni.).

- Družba C8 d.o.o. je načrtovala začetek proizvodnje izdelka (v količini 5.000 kosov). Za izdelavo takšne količine izdelkov je potreben raznovrsten material. Ves potreben material je družba v skupni vrednosti 20.000 EUR kupila pri različnih dobaviteljih. Družba C8 d.o.o. je do konca poslovnega leta tri čtrtine zneska kupljenega materiala poplačala z nakazili denarnih sredstev s svojega transakcijskega računa dobaviteljem.

- Družba C8 d.o.o. je zaradi načrtovane proizvodnje potrebovala poseben stroj/napravo. Takoj na začetku leta je družba stroj/napravo v vrednosti 15.000 EUR kupila pri dobavitelju družbi MM d.o.o. Družba C8 d.o.o. je do konca poslovnega leta poplačala dve tretjini zneska za kupljen stroj/napravo z nakazilom denarnih sredstev s svojega transakcijskega računa. (Opomba: davščin - npr. davka na dodano vrednost $-\mathrm{v}$ zvezi z nakupom stroja/naprave ni.).

- Družba C8 d.o.o. je stroj/napravo uporabljala celo leto, zaradi česar je obračunala t. i. amortizacijo zanj(o) v vrednosti 3.000 EUR. (Opomba: družba uporablja metodo enakomernega časovnega amortiziranja. Letna amortizacijska stopnja za stroj/napravo je $20 \%$.).

- Družba C8 d.o.o. je pri proizvodnji izdelkov ves material porabila. Družba vrednoti svoje zaloge proizvedenih izdelkov po polni stroškouni ceni. ${ }^{10}$ (Opomba: na začetku leta in na koncu leta ni nobenih zalog materiala.).

- Družba C8 d.o.o. je obračunala delo, ki ga je opravila pri njej zaposlena oseba CC v času proizvodnje izdelka (v količini 5.000 kosov). Skupna vrednost obračunanega dela je 8.000 EUR. (Opomba: družba vrednoti svoje zaloge izdelkov po polni stroškovni ceni.) Družba C8 d.o.o. je v zvezi z obračunanim delom izvedla nakazili s svojega transakcijskega računa osebi CC in v državni proračun.

\footnotetext{
10 Obstaja več različnih metod vrednotenja zalog proizvodov oz. učinkov v podjetju. Podrobneje o tem glejte opombo 1.
} 
- Družba C8 d.o.o. je prodala celotno zalogo proizvedenega izdelka kupcu MAKSI d.o.o. Kupec je do konca poslovnega leta poplačal štiri petine zneska opravljenega nakupa v vrednosti 35.000 EUR z nakazili denarnih sredstev na transakcijski račun družbe C8 d.o.o. (Opomba: davščin - npr. davka na dodano vrednost - v zvezi s prodajo proizvedenega izdelka ni.).

- Poslovodstvo družbe C8 d.o.o. je takoj po ustanovitvi odobrilo posojilo v višini 20.000 EUR (nepovezani) družbi KARTA d.o.o. Posojilodajalec je skladno s posojilno pogodbo nakazal prvo tranšo posojila družbi na njen transakcijski račun v vrednosti 10.000 EUR. Druga tranša bo skladno s posojilno pogodbo nakazana po enem letu od sklenitve posojilne pogodbe. (Opomba: stroškov v zvezi z odobritvijo in nakazilom posojila ni.).

- Družba C8 d.o.o. pred koncem leta obračuna obresti iz naslova danega posojila v skupni vrednosti 4.000 EUR. Družba C8 d.o.o. je do konca poslovnega leta prejela polovico zneska obračunanih obresti z nakazilom denarnih sredstev na svoj transakcijski račun s strani posojilojemalke družbe KARTA d.o.o. (Opomba: stroškov in davščin v zvezi s prejemom nakazila obresti ni.).

\section{Naloga in vprašanja (z navodili):}

- Izdelajte (poenostavljeno) shemo bilance stanja družbe C8 d.o.o. na začetku leta.

- Izdelajte (poenostavljeno) shemo izkaza poslovnega izida družbe C8 d.o.o. za poslovno leto. (Opomba: davka na dobiček - natančneje: davka od dohodka pravnih oseb - ni.)

- Če ima, katere prihodke in/ali odhodke ima družba? Koliko?

- Kateri je poslovni izid? Kolikšen?

- Izdelajte (poenostavljeno) shemo bilance stanja družbe C8 d.o.o. na koncu leta.

- Katera sredstva (premoženje) in obveznosti (do virov sredstev) ima družba? Koliko?

- Kolikšna je knjigovodska vrednost kapitala družbe?

- Kolikšna je knjigovodska vrednost poslovnega deleža vsakega družbenika?

(Opomba: prikažite iæračune in zapisite odgovore.) 


\section{Rešitev}

Izkaz poslovnega izida

\begin{tabular}{|c|c|c|c|}
\hline & ODHODKI & PRIHODKI & \\
\hline $\begin{array}{l}\text { Odhodki (stroškovna } \\
\text { vrednost prod. proiz.): }\end{array}$ & & 35.000 & $\begin{array}{l}\text { Prihodki od prodaje } \\
\text { proizvodov }\end{array}$ \\
\hline $\begin{array}{r}\text { Odhodki (stroški porablienega } \\
\text { materiala) }\end{array}$ & 20.000 & 4.000 & Prihodki (prejete obresti) \\
\hline Odhodki (stroški dela) & 8.000 & & \\
\hline Stroški (stroški amortizacije.) & 3.000 & & \\
\hline $\begin{array}{r}\text { Odhodki (stroški obresti za } \\
\text { izdane obveznice) }\end{array}$ & 2.000 & & \\
\hline Dobiček >> & 6.000 & & $<<$ Izguba \\
\hline SKUPAJ AKT. STRAN >> & 39.000 & 39.000 & $<<$ SKUPAJ PAS. STRAN \\
\hline
\end{tabular}

Bilanca stanja

\begin{tabular}{|c|c|c|c|}
\hline \multirow{3}{*}{$\begin{array}{r}\text { Osnovna sredstva (stroj) } \\
\text { Finančna naložba (dano } \\
\text { posojilo) }\end{array}$} & SREDSTVA & $\begin{array}{c}\text { OBV. DO } \\
\text { VIROV SRED. }\end{array}$ & \multirow[b]{2}{*}{ Osnovni kapital (vpoklican) } \\
\hline & 12.000 & \multirow[t]{2}{*}{20.000} & \\
\hline & 20.000 & & $\begin{array}{ll}10.000 & \text { Drušbenik } A A(0,5) \\
10.000 & \text { Drušbenik } B B(0,5)\end{array}$ \\
\hline Terjatev za obr. obresti (za & \multirow[t]{2}{*}{2.000} & 6.000 & \multirow[t]{2}{*}{$\begin{array}{l}<<\text { Posl. izid (dobiček iz } \\
\text { IPI) }\end{array}$} \\
\hline dano posojilo) & & & \\
\hline Terjatev do kupca & 7.000 & 10.000 & \multirow{5}{*}{$\begin{array}{l}\text { Obveznost za izdane vredn. } \\
\text { pap. (izdane obveznice) } \\
\text { Dolg (obv.) za plačilo } \\
\text { obresti za izd. obv. } \\
\text { Dolg (obv.) za nakazilo } \\
\text { preostanka danega posojila } \\
\text { Dolg (obv.) do dobavitelja } \\
<<\text { SKUPAJ OBV. }\end{array}$} \\
\hline Denarna sredstva (na TR) & 16.000 & 1.000 & \\
\hline & & 10.000 & \\
\hline \multirow[b]{2}{*}{ SKUPAJ SRED. >> } & & 10.000 & \\
\hline & 57.000 & 57.000 & \\
\hline
\end{tabular}





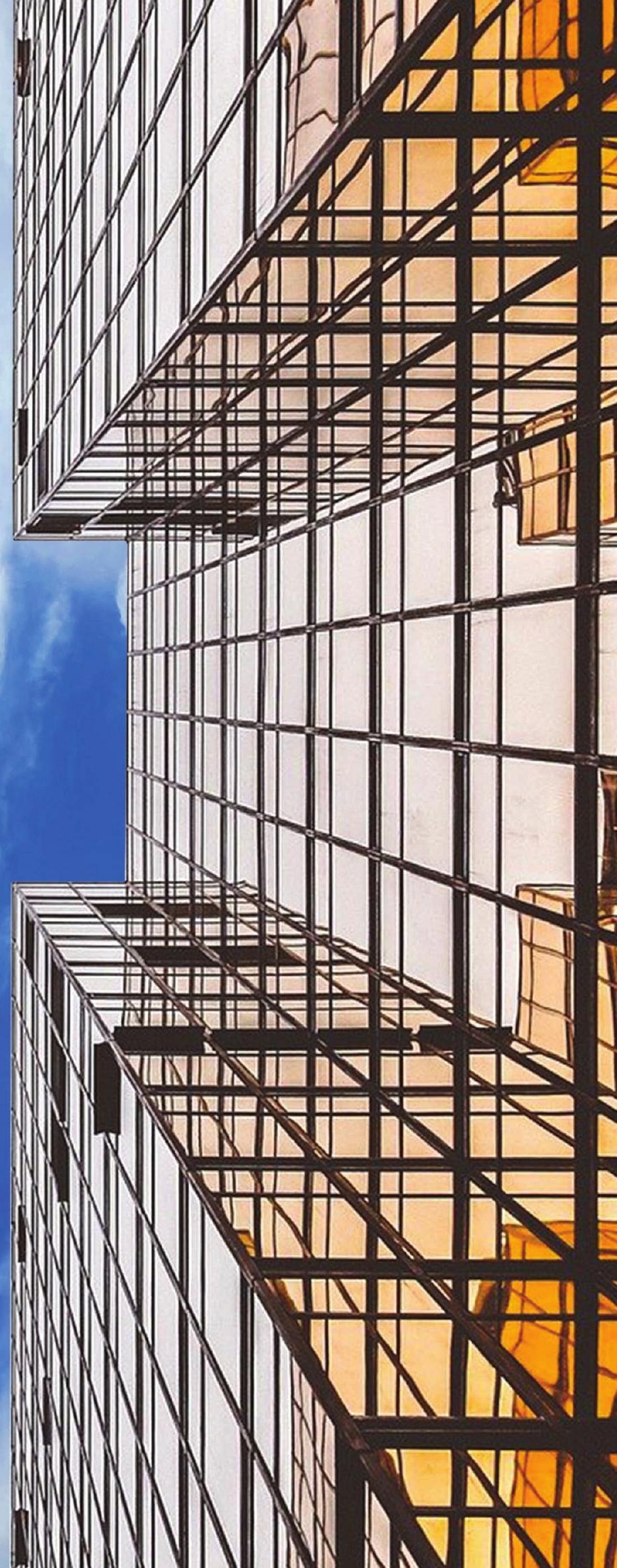


ŠTUDIJSKO GRADIVO PRI PREDMETU

KORPORACIJSKO IN KONCERNSKO PRAVO: ZBIRKA VAJ

J. Prostor in D. Zdolsek

\section{SKLOP VAJ Z OZNAKO: D}

\section{Vaja D1}

Tanja Blatnik in Andrej Sever sta ustanovila d.o.o. z 10.000 EUR osnovnega kapitala. Vsak od njiju ima $50 \%$ poslovni delež v tej družbi. Tanja je zagotovila stvarni vložek v višini 5.000 EUR, Andrej pa bo zagotovil 5.000 EUR denarnega vložka. Od teh 5.000 EUR pa je ob ustanovitvi vplačal le 3.500 EUR.

\section{Vprašanja:}

- Katera sredstva (premoženje) in obveznosti (do virov sredstev) ima družba? Koliko?

- Čez pol leta od ustanovitve družba nujno potrebuje še nevplačane zneske. Kaj lahko stori?

- Kaj se zgodi, če Andrej ne vplača preostalega zneska, ki se ga je zavezal vplačati?

- Ali bi bila rešitev enaka, če bi bil Andrej namesto družbenik d.o.o. delničar d.d.? 


\section{Vsebina / smoter naloge je usvojiti naslednje pojme in problematiko:}

- osnovni kapital - osnovni vložek - poslovni delež;

- $\quad$ sredstva gospodarske družbe;

- $\quad$ premoženje družbe (neto = lastni kapital; bruto = vrednost sredstev);

- obveznosti do virov sredstev;

- $\quad$ kapital - vpoklicani kapital - nevpoklicani kapital (kot odbitna postavka) (65. člen ZGD-1);

- bilančno izkazovanje nevpoklicanega kapitala;

- poziv za izpolnitev glavne obveznosti, opozorilo;

- $\quad$ kaducitetni postopek, izključitev družbenika (486. člen ZGD-1);

- jamstvo zamudnikovih prednikov (487. člen ZGD-1);

- dražba poslovnega deleža (488. člen ZGD-1);

- odgovornost so-družbenikov za vplačilo (489. člen ZGD-1);

- primerjanje ureditve v d.d. (222. - 225. člen ZGD-1).

\section{Rešitev}

Bilanca stanja

\begin{tabular}{|c|c|c|c|}
\hline \multirow[b]{2}{*}{ Nepremičnina (posl. prostor) } & SREDSTVA & OBV. DO & \multirow{4}{*}{$\begin{array}{l}\text { Nevpoklicani kapital (kot } \\
\text { odbitna postavka) } \\
\text { Osnovni kapital } \\
\text { << SKUPAJ OBV. }\end{array}$} \\
\hline & 5.000 & -1.500 & \\
\hline Denarna sredstva (na TR) & 3.500 & 10.000 & \\
\hline SKUPAI SRED. >> & 8.500 & 8.500 & \\
\hline
\end{tabular}

Ko družba kliče na vplačilo preostanka osnovnega vložka:

Bilanca stanja

\begin{tabular}{|c|c|c|c|}
\hline \multirow{5}{*}{$\begin{array}{r}\text { Nepremičnina (posl. prostor) } \\
\text { Terjatve za nevplačan } \\
\text { vpoklican OK } \\
(\text { do »Andreja« })\end{array}$} & SREDSTVA & OBV. DO & \multirow{6}{*}{ Osnovni kapital } \\
\hline & & VIROV SRED. & \\
\hline & 5.000 & \multirow[t]{4}{*}{10.000} & \\
\hline & & & \\
\hline & 1.500 & & \\
\hline Denarna sredstva (na TR) & 3.500 & & \\
\hline SKUPAJ SRED. >> & 10.000 & 10.000 & << SKUPAJ OBV. \\
\hline
\end{tabular}

Če bi prišlo do vplačila preostanka 1.500, potem se terjatev (do Andreja) zmanjša na 0 , denarna sredstva povečajo na 5.000 . 


\section{Vaja D2}

Tanja Blatnik in Andrej Sever se odločita, da bo imela d.o.o., katere družbenika bosta, 10.000 EUR osnovnega kapitala. Vsak od njiju bo imel $50 \%$ poslovni delež v tej družbi. Tanja je zagotovila stvarni vložek v višini 5.000 EUR, Andrej pa je zagotovil 5.000 EUR denarnega vložka.

Družbo sta ustanovila na začetku leta. Družba je tekom leta kupila različne storitve pri dobaviteljih v vrednosti 4.000 EUR, ki jih je poplačala $\mathrm{z}$ nakazilom denarnih sredstev s svojega transakcijskega računa.

\section{Vprašanja:}

- Katera sredstva (premoženje) in obveznosti (do virov sredstev) ima družba? Koliko?

- Koliko osnovnega kapitala ima ta družba?

- Koliko premoženja je na razpolago za upnike?

- Koliko znaša knjigovodska vrednost posameznega poslovnega deleža?

\section{Vsebina / smoter naloge je usvojiti naslednje pojme in problematiko:}

- dobiček, izguba;

- $\quad$ vpliv dobička in izgube na znesek osnovnega kapitala;

- knjigovodska vrednost;

- $\quad$ knjigovodska vrednost poslovnega deleža.

\section{Rešitev}

Bilanca stanja

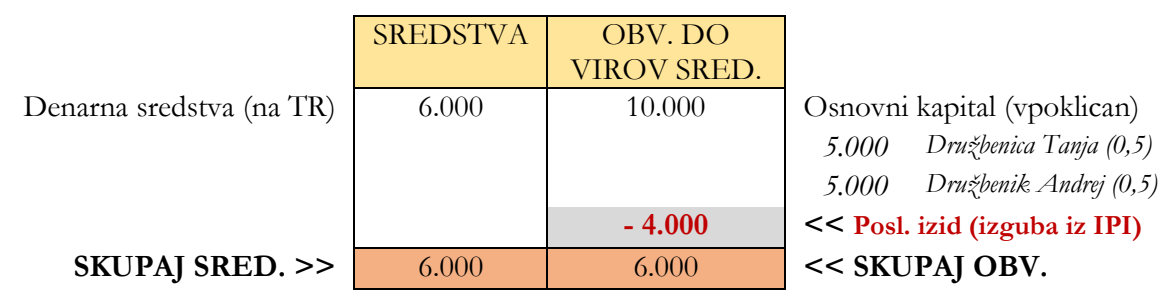




\section{Vaja D3}

Tanja Blatnik in Andrej Sever se odločita, da bo imela d.o.o., katere družbenika bosta, 10.000 EUR osnovnega kapitala. Vsak od njiju bo imel $50 \%$ poslovni delež v tej družbi. Tanja je zagotovila stvarni vložek v višini 5.000 EUR, Andrej pa je zagotovil 5.000 EUR denarnega vložka.

Družbo sta ustanovila na začetku leta. Družba je tekom leta najela 4.000 EUR kredita.

\section{Vprašanja:}

- Katera sredstva (premoženje) in obveznosti (do virov sredstev) ima družba? Koliko?

- Koliko znaša osnovni kapital družbe?

- Koliko premoženja je na razpolago za upnike?

- Koliko znaša knjigovodska vrednost posameznega poslovnega deleža?

\section{Vsebina / smoter naloge je usvojiti naslednje pojme in problematiko:}

- financiranje $z$ lastniškim kapitalom;

- financiranje z dolžniškim kapitalom;

- vpliv najema kredita na znesek osnovnega kapitala;

- $\quad$ vpliv najema kredita na obsega premoženja družbe;

- vpliv dolžniškega kapitala na knjigovodsko vrednost poslovnega deleža družbe.

\section{Rešitev}

Bilanca stanja

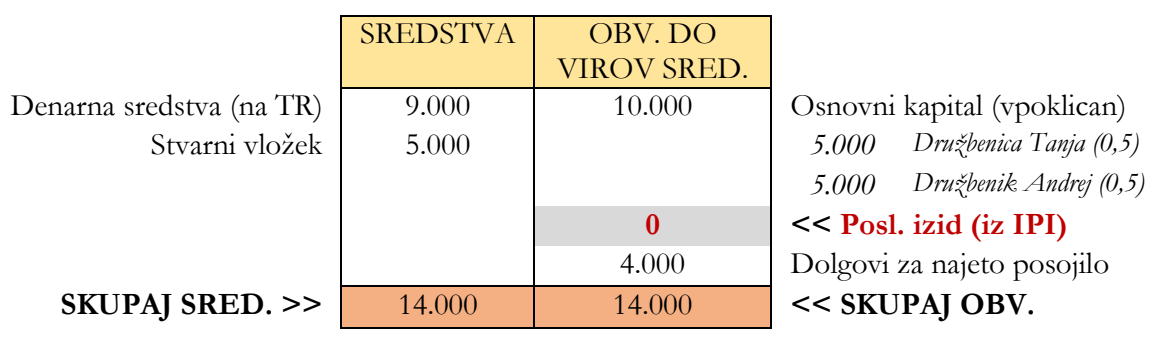


Vaja D4

Naloga: dopolnite manjkajoči del besedila.

Družba ima dva družbenika, vsak ima $50 \%$ poslovni delež. Osnovni kapital je 500 enot, torej je vsak družbenik v družbo vložil enot. Družba je pri poslovanju ustvarila 1.000 enot dobička (pri čemer je družba hkrati na koncu leta imela tudi za 1.000 enot več denarnih sredstev kot na začetku leta). Z ekonomskega vidika ima vsak od družbenikov v družbi

enot, družba pa ima enot premoženja. Družbenika tretjemu dopustita vstop v družbo na način, da ima vsak od njih $1 / 3$ poslovni delež. Transakcija se izvrši po knjigovodskih vrednostih poslovnih deležev. Ta tretja oseba bi morala $\mathrm{v}$ družbo vplačati skupaj enot, in sicer: enot $\mathrm{v}$ osnovni kapital, in enot

$$
\mathrm{v}
$$
. Družba ima potem skupaj

enot premoženja in enot obveznosti do virov sredstev.

\section{Vprašanja:}

- Katere kategorije v tem primeru sestavljajo pasivno stran bilance stanja?

- Opredelite bilanco stanja pred vstopom tretjega $\mathrm{v}$ družbo in po tem. Katera sredstva (premoženje) in obveznosti (do virov sredstev) ima družba? Koliko?

\section{Vsebina / smoter naloge je usvojiti naslednje pojme in problematiko:}

- povečanje osnovnega kapitala;

- primarni in sekundarni trg kapitala;

- razlika med vlaganjem sredstev v gospodarsko družbo z namenom pridobitve »lastniške« udeležbe $\mathrm{v}$ družbi ter na drugi strani pridobitvijo udeležbe $\mathrm{v}$ družbi $\mathrm{z}$ nakupom poslovnega deleža;

- kapitalska rezerva 1. kategorije;

- bilanca stanja. 


\section{Rešitev}

Bilanca stanja (PRED DOKAPITALIZACIJO)

\begin{tabular}{|c|c|c|c|}
\hline \multirow{7}{*}{ Denarna sredstva (na TR) } & SREDSTVA & $\begin{array}{c}\text { OBV. DO } \\
\text { VIROV SRED. }\end{array}$ & \multirow[b]{2}{*}{ Osnovni kapital (vpoklican) } \\
\hline & \multirow[t]{6}{*}{1.500} & \multirow[t]{4}{*}{500} & \\
\hline & & & 250 Družbenik $A$ \\
\hline & & & 250 Druğbenik B \\
\hline & & & O Dru气̌benik C \\
\hline & & 0 & Kapitalske rezerve \\
\hline & & 1.000 & $<<$ Posl. izid (dobiček iz IPI) \\
\hline SKUPAJ SRED. >> & 1.500 & 1.500 & << SKUPAJ OBV. \\
\hline
\end{tabular}

Bilanca stanja (PO DOKAPITALIZACIJI)

\begin{tabular}{|c|c|c|c|}
\hline \multirow{7}{*}{ Denarna sredstva (na TR) } & SREDSTVA & OBV. DO & \multirow{8}{*}{ 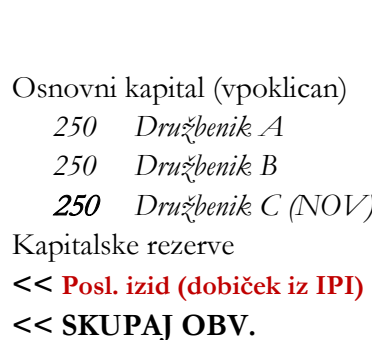 } \\
\hline & 2.250 & $\frac{\text { VIROV SRED. }}{750}$ & \\
\hline & & & \\
\hline & & & \\
\hline & & & \\
\hline & & 500 & \\
\hline & & 1.000 & \\
\hline SKUPAJ SRED. >> & 2.250 & 2.250 & \\
\hline
\end{tabular}

\begin{tabular}{|c|c|c|c|}
\hline & $\begin{array}{c}\text { Poslovni } \\
\text { delež } \\
\text { družbenika }\end{array}$ & Osn. kap. & $\begin{array}{c}\text { Dopl. v } \\
\text { kap. rez. }\end{array}$ \\
\hline Družbenik A & 0,3333 & 250 & \\
\hline Družbenik B & 0,3333 & 250 & \\
\hline Družbenik C & $\mathbf{0 , 3 3 3 3}$ & $\mathbf{2 5 0}$ & $\mathbf{5 0 0}$ \\
\hline SKUPAJ & 1,0 & 750 & 500 \\
\hline
\end{tabular}

\section{Vaja D5}

Naloga: dopolnite manjkajoči del besedila.

Družba ima dva družbenika, poslovni delež vsakega od njiju znaša $50 \%$. Osnovni vložek vsakega družbenika je 50 enot, osnovni kapital družbe znaša enot. Družba pri poslovanju ustvari 1.000 enot dobička (pri čemer je družba hkrati na koncu leta imela tudi za 1.000 enot več denarnih sredstev kot na začetku leta). Z ekonomskega vidika ima vsak od družbenikov v 
družbi enot, družba pa ima

enot premoženja. Družbenika tretjemu dopustita vstop v družbo po poti povečanja osnovnega kapitala družbe trg), pri čemer bo imel tretji $50 \%$ poslovni delež v družbi. Transakcija se izvrši po knjigovodskih vrednostih poslovnih deležev.

\section{Vprašanja:}

- Koliko znaša osnovni vložek vsakega posameznega družbenika po dokapitalizaciji?

- Koliko mora tretja oseba plačati in komu?

- Opredelite bilanco stanja pred vstopom tretjega v družbo in po tem. Katera sredstva (premoženje) in obveznosti (do virov sredstev) ima družba? Koliko?

\section{Rešitev}

\section{Bilanca stanja (PRED DOKAPITALIZACIJO)}

\begin{tabular}{|c|c|c|c|}
\hline \multirow{7}{*}{ Denarna sredstva (na TR) } & SREDSTVA & $\begin{array}{c}\text { OBV. DO } \\
\text { VIROV SRED. }\end{array}$ & \multirow{8}{*}{ 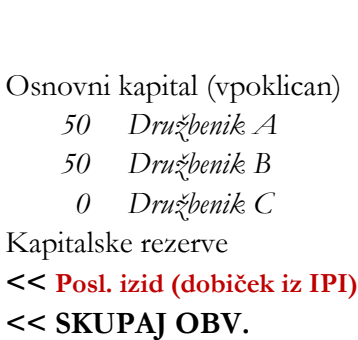 } \\
\hline & 1.100 & 100 & \\
\hline & & & \\
\hline & & & \\
\hline & & & \\
\hline & & 0 & \\
\hline & & 1.000 & \\
\hline SKUPAJ SRED. >> & 1.100 & 1.100 & \\
\hline
\end{tabular}

Bilanca stanja (PO DOKAPITALIZACIJI)

\begin{tabular}{|c|c|c|c|}
\hline \multirow{7}{*}{ Denarna sredstva (na TR) } & SREDSTVA & $\begin{array}{c}\text { OBV. DO } \\
\text { VIROV SRED. }\end{array}$ & \multirow{8}{*}{ 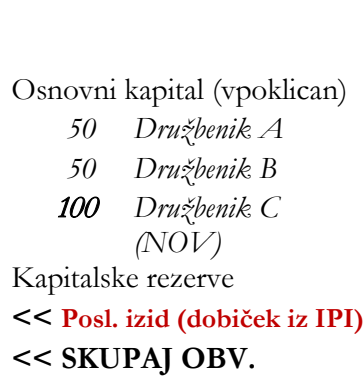 } \\
\hline & 2.200 & 200 & \\
\hline & & & \\
\hline & & & \\
\hline & & & \\
\hline & & 1.000 & \\
\hline & & 1.000 & \\
\hline SKUPAJ SRED. >> & 2.200 & 2.200 & \\
\hline
\end{tabular}




\begin{tabular}{|c|c|c|c|}
\hline & $\begin{array}{c}\text { Poslovni } \\
\text { delež } \\
\text { družbenika }\end{array}$ & Osn. kapital & $\begin{array}{c}\text { Dopl. v } \\
\text { kap. rez. }\end{array}$ \\
\hline Družbenik A & 0,25 & 50 & \\
\hline Družbenik B & 0,25 & 50 & \\
\hline Družbenik C & $\mathbf{0 , 5 0}$ & $\mathbf{1 0 0}$ & $\mathbf{1 . 0 0 0}$ \\
\hline SKUPAJ & 1,0 & 200 & 1.000 \\
\hline
\end{tabular}

\section{Vaja D6}

\section{Naloga: dopolnite manjkajoči del besedila.}

Družba ima dva družbenika, poslovni delež vsakega od njiju znaša $50 \%$. Osnovni vložek vsakega družbenika je 50 enot, osnovni kapital družbe znaša enot. Družba pri poslovanju ustvari 1.000 enot dobička (pri čemer je družba hkrati na koncu leta imela tudi za 1.000 enot več denarnih sredstev kot na začetku leta). Družbenika tretjemu dopustita vstop v družbo tako, da mu prodata vsak enak del svojega poslovnega deleža

trg), pri čemer bo imel tretji 50 \% poslovni delež v družbi. Transakcija se izvrši po knjigovodskih vrednostih poslovnih deležev.

\section{Vprašanja:}

- Koliko znaša osnovni vložek vsakega družbenika po vstopu tretjega v družbo?

- Koliko mora tretji plačati za vstop v družbo in komu?

- Opredelite bilanco stanja pred vstopom tretjega v družbo in po tem. Katera sredstva (premoženje) in obveznosti (do virov sredstev) ima družba? Koliko?

\section{Vsebina / smoter naloge je usvojiti naslednje pojme in problematiko:}

- $\quad$ kako pridobitev poslovnega deleža na sekundarnem trgu vpliva na premoženje oz. bilanco stanja gospodarske družbe. 


\section{Rešitev}

Bilanca stanja

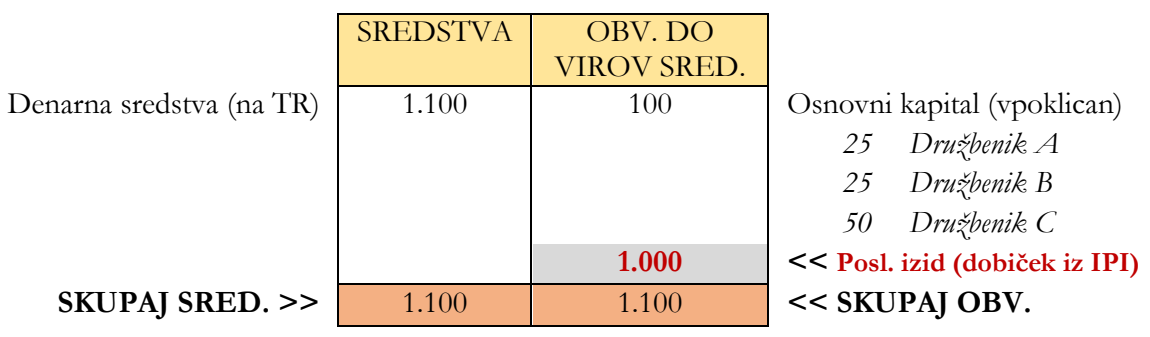

\begin{tabular}{|c|c|}
\hline $\begin{array}{c}\text { Izračun } \\
\text { sprem. } \\
\text { posl. del.: }\end{array}$ & $\begin{array}{c}\text { [Potr. } \\
\text { plačilo] }\end{array}$ \\
\hline$-0,2500$ & -275 \\
\hline$-0,2500$ & -275 \\
\hline 0,5000 & \\
\hline 0 & -550 \\
\hline
\end{tabular}

\begin{tabular}{|c|c|c|c|c|}
\cline { 2 - 5 } & $\begin{array}{c}\text { "Star" OK } \\
\text { (vpokl.) }\end{array}$ & $\begin{array}{c}\text { Izračun } \\
\text { sprem. OK } \\
\text { (vpok.): }\end{array}$ & $\begin{array}{c}\text { Nov OK } \\
\text { (vpokl.) }\end{array}$ & $\begin{array}{c}\text { Preverba } \\
\text { ohr. } \\
\text { razmerja: }\end{array}$ \\
\cline { 2 - 5 } Družbenik A & 50 & -25 & 25 & 0,5 \\
\cline { 2 - 5 } Družbenik B & 50 & -25 & 25 & 0,5 \\
\cline { 2 - 5 } Družbenik C & & 50 & 50 & \\
\cline { 2 - 5 } & 100 & 0 & 100 & \\
\cline { 2 - 5 } & \multicolumn{3}{|c}{}
\end{tabular}

\section{Vaja D7}

Družbenika A in B ustanovita d.o.o., vsak z denarnim vložkom 100.000 EUR. V družbi se zgodijo naslednji poslovni dogodki tekom leta:

- Po ustanovitvi poslovodja kupi poslovne prostore v vrednosti 100.000 EUR, ki jih poplača z nakazilom denarnih sredstev s transakcijskega računa družbe.

- Za preostali znesek kupi delnice, ki jih tudi poplača z nakazilom.

- Na podlagi delnic pred koncem leta prejme družba nakazilo dividend v višini $10 \%$ vrednosti kupljenih delnic.

- Družba izda obveznice za 1.000.000 EUR, ki jih uspešno proda.

- Za te obveznice družba pred koncem leta plača obresti v višini $5 \%$ vrednosti izdanih obveznic.

- Družba kupi in plača investicijske kupone za 1.000.000 EUR.

- Družba kupi in plača za 200.000 EUR materiala, ki ga porabi v tem letu.

- Družba tekom leta proda in prejme plačilo proizvodov v skupni višini 5.000.000 EUR na svoj transakcijski račun. 
- Po koncu leta vstopi v družbo družbenik C, ki ima v družbi polovični delež. Družbeniki se dogovorijo, da tretji v družbo vstopi po poti dokapitalizacije, transakcija pa se izvrši po knjigovodskih vrednostih poslovnih deležev.

\section{Naloge oz: uprašanja:}

- Opredelite bilanco stanja in izkaz poslovnega izida pred vstopom tretjega v družbo ter bilanco stanja po koncu prvega leta poslovanja te družbe.

\section{Namig}

- Za pomoč pri reševanju tovrstnih nalog je priporočljivo predelati poglavje 2. 2. z naslovom Povezano spreminjanje gospodarskih kategorij v B. Korošec et al., Osnove računovodstva, Univerza v Mariboru, Ekonomsko-poslovna fakulteta, Maribor, 2016, str. 79-90.

- Poslovni dogodek nakupa poslovnega prostora ali delnic pomeni le spremembo strukture premoženja, ki se s tem niti ne poveča niti ne zmanjša.

- Dividenda kot prihodek.

- Izdaja obveznic ${ }^{11}$ kot financiranje z dolžniškim kapitalom.

- Poslovni dogodek izdaje obveznic pomeni povečanje sredstev gospodarske družbe (bruto premoženja), s čimer se povečajo tudi obveznosti gospodarske družbe.

- Obresti, ki jih družba plača, kot odhodek.

- Nakup investicijskih kuponov ${ }^{12}$ kot pridobitev dolgoročne finančne naložbe.

- Strošek materiala in vpliv tega stroška na poslovni izid.

\section{Vsebina / smoter naloge je usvojiti naslednje pojme in problematiko:}

- povečanje osnovnega kapitala;

- primarni in sekundarni trg kapitala;

- razlika med vlaganjem sredstev v gospodarsko družbo z namenom pridobitve »lastniške« udeležbe $\mathrm{v}$ družbi ter na drugi strani pridobitvijo udeležbe $\mathrm{v}$ družbi z nakupom poslovnega deleža;

- $\quad$ kapitalska rezerva 1. kategorije;

- bilanca stanja.

\footnotetext{
${ }^{11}$ Obveznica je pisna listina, s katero se izdajatelj zavezuje, da bo osebi, navedeni na njej, ali po njeni odredbi oziroma prinosniku obveznice izplačal določenega dne $\mathrm{v}$ obveznici naveden znesek oziroma znesek anuitetnega kupona (1. odst. 26. čelna Zakon o vrednostnih papirjih (ZVP), Uradni list SFRJ, št. 64/89, 29/90, Uradni list RS, št. 30/93 ZGD in 6/94 - ZTVP). Obveznica vsebuje naslednje glavne elemente: oznako, da je obveznica; firmo oziroma ime in sedež izdajatelja obveznice; firmo oziroma ime kupca obveznice ali oznako, da se obveznica glasi na prinosnika; denarni znesek, na katerega se glasi obveznica; višino obrestne mere, če je predvideno plačilo obresti; odstotek udeležbe pri dobičku, če je predvidena; roke za odplačilo glavnice in obresti; kraj in datum izdaje ter serijsko in kontrolno številko obveznice; faksimile podpisa pooblaščenih oseb izdajatelja obveznice ter pravice iz obveznice (1. odst. 33. člena ZVP).

${ }^{12}$ Investicijski kupon je vrednostni papir, katerega izdajatelj je družba za upravljanje, ki se glasi na enoto, več enot ali del enote premoženja vzajemnega sklada, in daje imetniku investicijskega kupona naslednje pravice:

1. pravico od družbe za upravljanje zahtevati izplačilo odkupne vrednosti enot premoženja vzajemnega sklada, na katere se glasi investicijski kupon;

2. pravico do izplačila sorazmernega dela likvidacijske mase v primeru likvidacije vzajemnega sklada;

3. pravico do izplačila sorazmernega dela čistega dobička oziroma prihodkov vzajemnega sklada, če pravila upravljanja vzajemnega sklada tako določajo,

kot to določa 1. odst. 227. člena Zakona o investicijskih skladih in družbah za upravljanje (ZISDU-3), Uradni list RS, št. $31 / 15,81 / 15$ in $77 / 16$.
} 


\section{Rešitev}

Izkaz poslovnega izida

\begin{tabular}{|c|c|c|c|}
\hline & ODHODKI & PRIHODKI & \multirow{5}{*}{$\begin{array}{l}\text { Prihodki od prodaje } \\
\text { proizvodov (prod. vr.) } \\
\text { Finančni prihodki (od } \\
\text { prejetih dividend) } \\
<<\text { Izguba } \\
<<\text { SKUPAJ PAS. } \\
\text { STRAN }\end{array}$} \\
\hline $\begin{array}{r}\text { Odhodki (stroški porab. } \\
\text { materiala) }\end{array}$ & 200.000 & 5.000 .000 & \\
\hline $\begin{array}{r}\text { Odhodki (stroški obresti } \\
\text { zaradi fin.) }\end{array}$ & 50.000 & 10.000 & \\
\hline Dobiček >> & 4.760 .000 & & \\
\hline KUPAJ AKT. STRAN >> & 5.010 .000 & 5.010 .000 & \\
\hline
\end{tabular}

Bilanca stanja (PRED DOKAPITALIZACIJO)

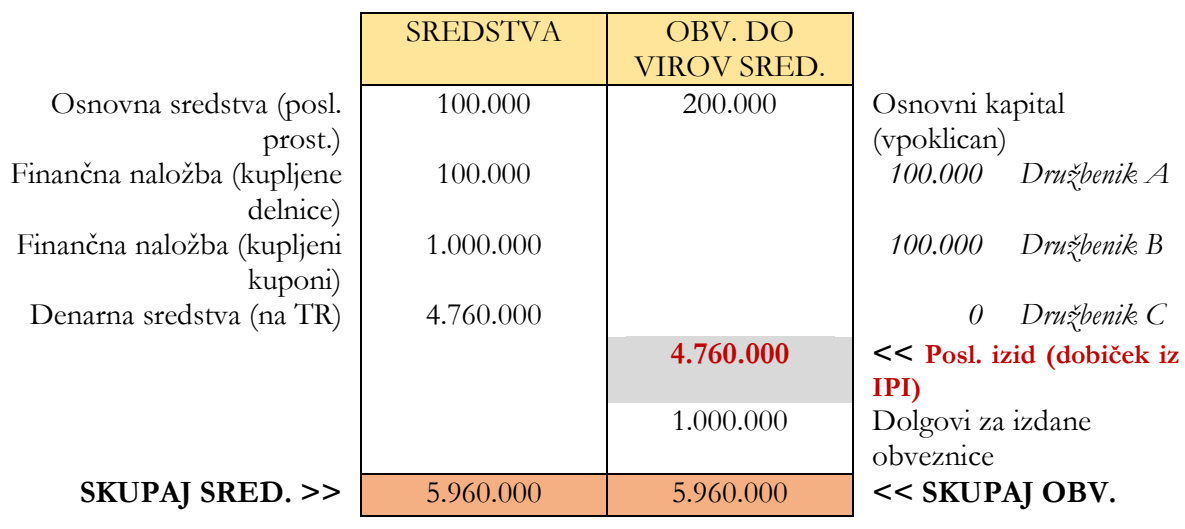

Bilanca stanja (PO DOKAPITALIZACIJI)

\begin{tabular}{|c|c|c|c|}
\hline \multirow[b]{3}{*}{$\begin{array}{r}\text { Osnovna sredstva (posl. } \\
\text { prost.) }\end{array}$} & SREDSTVA & OBV.DO & \\
\hline & & VIROV SRED. & \\
\hline & 100.000 & 400.000 & $\begin{array}{l}\text { Osnovni kapital } \\
\text { (vpoklican) }\end{array}$ \\
\hline $\begin{array}{r}\text { Finančna naložba (kupljene } \\
\text { delnice) }\end{array}$ & 100.000 & & Drų̧benik. $A$ \\
\hline $\begin{array}{r}\text { Finančna naložba (kupljeni } \\
\text { kuponi) }\end{array}$ & 5.960 .000 & & 100.000 Druð̌benik B \\
\hline \multirow[t]{4}{*}{ Denarna sredstva (na TR) } & 4.760 .000 & & 200.000 Družbenik. C \\
\hline & & 4.760 .000 & \multirow{4}{*}{$\begin{array}{l}\text { Kapitalske rezerve } \\
<<\text { Posl. izid (dobiček iz } \\
\text { IPI) } \\
\text { Dolgovi za izdane } \\
\text { obveznice } \\
<<\text { SKUPAJ OBV. }\end{array}$} \\
\hline & & 4.760 .000 & \\
\hline & & 1.000 .000 & \\
\hline SKUPAJ SRED. >> & 10.920 .000 & 10.920 .000 & \\
\hline
\end{tabular}




\begin{tabular}{|c|c|c|c|}
\hline & $\begin{array}{c}\text { Poslovni } \\
\text { delež } \\
\text { družbenika }\end{array}$ & Osn. kapital & $\begin{array}{c}\text { Dod. v } \\
\text { kap. rez. }\end{array}$ \\
\hline Družbenik A & 0,2500 & 100.000 & \\
\hline Družbenik B & 0,2500 & 100.000 & \\
\hline Družbenik C & $\mathbf{0 , 5 0 0 0}$ & $\mathbf{2 0 0 . 0 0 0}$ & $\mathbf{4 . 7 6 0 . 0 0 0}$ \\
\hline SKUPAJ & 1,0 & 400.000 & 4.760 .000 \\
\hline
\end{tabular}

\section{Vaja D8}

Tanja Blatnik in Andrej Sever imata podjetniško idejo - tiskala bosta različne motive na različne podlage. Zamislila sta si, da bi to dejavnost opravljala v pravnoorganizacijski obliki d.o.o.

\section{Vprašanja:}

- Svetujte jima glede kapitalskih vprašanj v družbi!

- Koliko premoženja morata zagotoviti družbi?

- Ali lahko družbo ustanovita s terjatvijo, ki jo imata oba do svojega nekdanjega delodajalca (vsak v višini 5.000 EUR)?

\section{Vsebina / smoter naloge je usvojiti naslednje pojme in problematiko:}

- najnižji znesek osnovnega vložka;

- denarni vložek, stvarni vložek, stvarni prevzem;

- pri denarnem vložku zagotoviti vsaj 1/4 osnovnega vložka;

- vendar minimalno 7.500 EUR (475. člen ZGD-1);

- $\quad$ poročilo o stvarnih vložkih (476. člen ZGD-1);

- $\quad$ vključitev revizorja (476. člen ZGD-1);

- tržna vrednost terjatve kot stvarnega vložka;

- $\quad$ terjatev mora biti odstopljiva, njena vrednost pa objektivno ugotovljiva in dokazljiva; ${ }^{13}$

- terjatev naj bo tudi izterljiva, dvom o tem se upošteva pri vrednotenju terjatve; morebitna nezmožnost uveljavitve terjatve ob zapadlosti povzroči nastanek diferenčne odgovornosti po 5. odst. 475. člena ZGD-1 (»znova oživi« dolžnost vplačila denarnega vložka kot primarna dolžnost); ${ }^{14}$

- odškodninska odgovornost družbenikov in poslovodij ob ustanovitvi (479. člen ZGD-1);

- VSL I Cpg 1377/2013;

- $\quad$ prijava za vpis v register - vloga registrskega organa, če meni, da je vrednost stvarnega vložka manjša od zneska osnovnega vložka, za katerega je dan stvarni vložek.

\footnotetext{
${ }^{13}$ P. Podgorelec v S. Prelič et al., Družba z omejeno odgovornostjo, GV Založba, Ljubljana, 2009, str. 112.

14 Prav tam, str. 112, 118.
} 


\section{Vaja D9}

Tanja Blatnik in Andrej Sever, ki sta nepovezani osebi, se odločita, da bo imela družba TISKANJE BS d.o.o., katere družbenika bosta, 10.000 EUR osnovnega kapitala. Vsak od njiju bo imel $50 \%$ poslovni delež v tej družbi. Tanja je zagotovila stvarni vložek v višini 5.000 EUR, Andrej pa 5.000 EUR denarnega vložka. Čez dve leti od ustanovitve družbe Andrej spozna, da je Tanja že nekaj mesecev družbenica v družbi TM-GRAFIT d.o.o., ki jo je ustanovila s svojim možem. Družbi opravljata konkurenčno dejavnost.

\section{Naloga o\%: vprašanje:}

- Kaj svetujete Andreju? Za pravni nasvet navedite pravne podlage.

\section{Vsebina / smoter naloge je usvojiti naslednje pojme in problematiko:}

- $\quad$ ureditev prepovedi konkurence za d.o.o. (41. - 42. člen ZGD-1);

- izključitev družbenika iz d.o.o. in posledice (501. - 502. člen ZGD-1).

\section{Vaja D10}

Tanja Blatnik in Andrej Sever se odločita, da bo imela d.o.o., katere družbenika bosta, 30.000 EUR osnovnega kapitala. Vsak od njiju bo imel $50 \%$ poslovni delež v tej družbi. Tanja je zagotovila stvarni vložek v višini 25.000 EUR, Andrej pa je zagotovil 15.000 EUR denarnega vložka. A kasneje se ugotovi, da Tanja ni bila lastnica avtomobila, ki ga je zagotovila družbi kot stvarni vložek.

\section{Naloge o₹: vprašanja:}

- Svetujte družbi! Kaj lahko družba stori? Navedite pravno podlago za svoj pravni nasvet.

\section{Vsebina / smoter naloge je usvojiti naslednje pojme in problematiko:}

- VSL IV Cpg 345/2012 - kaducitetni postopek le za denarne vložke;

- družbenik je družbi izročil stvarni vložek, a dejansko ni bil lastnik izročenih premičnin, zato jih ni mogel veljavno prenesti na družbo;

- $\quad$ kljub temu je registrsko sodišče zavrnilo predlog družbe za vpis izključitve družbenika iz družbe, VSL pa je sklep registrskega sodišča potrdilo ; 
- $\quad$ v primeru, ko obveznosti zagotovitve stvarnega vložka zaradi stvarnih ali pravnih napak predmeta ni mogoče izpolniti, je družbenik dolžan plačati osnovni vložek v denarju;

- če obstajajo zakonski pogoji za odstop od pogodbe in se družba nanje sklicuje, stopi na mesto stvarnega vložka denarni vložek kot primarna družbenikova obveznost, ki torej »znova oživi« - sledi kaducitetni postopek, čeprav je bil prvotno dogovorjen stvarni vložek;15

- prim. 3. odst. 187. člena ZGD-1.

\section{Vaja D11}

Osebe A, B in C bi rade ustanovile d.d. s 40.000 EUR osnovnega kapitala in sto kosovnimi delnicami. A in B bi zagotovila vsak po 10.000 EUR, C pa bi zagotovil 20.000 EUR.

\section{Vprašanji:}

- Koliko delnic kupi vsak? Kolikšno je razmerje med družbeniki?

- C bi si poleg tega zagotovil še 5.000 EUR v kapitalske rezerve družbe. Ali lahko C odloži zagotovitev 5.000 EUR kapitalskih rezerv? Kolikšno je v tej situaciji razmerje med družbeniki? Poiščite pravno podlago za svoj odgovor.

\section{Vsebina / smoter naloge je usvojiti naslednje pojme in problematiko:}

- izračun pripadajočega zneska delnice;

- $\quad$ takojšnje vplačilo kapitalske rezerve 1. kategorije (4. odst. 191. člena ZGD-1).

\section{Vaja D12}

Osnovni kapital delniške družbe znaša 2.100.000 €. Vsak od treh delničarjev je imetnik delnic $\mathrm{v}$ nominalni višini $700.000 €$. Delničarja A in B sta lenuha in $\mathrm{v}$ družbi ne delata ničesar, delničar C pa opravlja funkcijo direktorja in gara noč in dan. Družba v poslovnem letu ustvari dobiček v višini $1.000 .000 €$.

\section{Vprašanje:}

- Kako se deli dobiček? Odgovor pravno obrazložite.

\footnotetext{
15 Prav tam, str. 123.
} 


\section{Vsebina / smoter naloge je usvojiti naslednje pojme in problematiko:}

- udeležba v osnovnem kapitalu kot merodajna za določitev delničarjevih korporacijskih pravic (1. odst. 231. člena ZGD-1);

- $\quad$ dispozitivnost ureditve delitve dobička (3. odst. 231. člena ZGD-1; 176. člen ZGD-1);

- ločiti korporacijskopravno razmerje od obligacijskega oziroma morebitnega delovnopravnega razmerja.

\section{Vaja D13}

Osebi A in B skleneta družbeno pogodbo, ki določa, da je osnovni kapital družbe z omejeno odgovornostjo je 5.000.000 € in je razdeljen na dva poslovna deleža $(50 \%)$. Oba družbenika vplačata osnovni vložek v višini $2.500 .000 €$.

Oseba A vplača osnovni vložek v denarju z vplačilom 2.500.000 €. Oseba B vplača stvarni vložek - poslovne prostore, katerih ocenjena vrednost je 7.500.000€.

O delitvi dobička družbena pogodba ne določa ničesar. Družba v prvem poslovnem letu ustvari bilančni dobiček v višini 1.000.000 €. Skupščina sklene, da se dobiček v celoti izplača družbenikoma.

\section{Vprašanje:}

- Kako se deli dobiček? Odgovor pravno obrazložite in opozorite na funkcijo kapitalske rezerve 1 . kategorije v tem primeru!

\section{Vsebina / smoter naloge je usvojiti naslednje pojme in problematiko:}

- udeležba v osnovnem kapitalu kot merodajna za določitev družbenikovih korporacijskih pravic (2. odst. 494. člena ZGD-1 za d.o.o.);

- dispozitivnost ureditve delitve dobička;

- funkcije kapitalske rezerve 1. kategorije.

\section{Vaja D14}

Družbeniki A, B in C ustanovijo d.o.o. A ima $50 \%$ poslovni delež, B in C pa vsak 25-odstotnega. A vplača osnovni vložek 100.000 EUR, B in C pa vplačata vsak 50.000 EUR. 
Po ustanovitvi družbe se zgodijo naslednji poslovni dogodki:

- Po ustanovitvi družbe poslovodja kupi poslovne prostore v vrednosti 50.000 EUR in strojno opremo za delavnico v vrednosti 100.000 EUR. Vse družba tudi poplača z nakazili s svojega transakcijskega računa.

- Družba kupi delnice druge družbe v vrednosti 30.000 EUR, katere prodajalcu delnic poplača z nakazilom s transakcijskega računa.

- Zaradi kupljenih delnic družba prejme dividende, ki v tem letu znašajo $10 \%$ vrednosti kupljenih delnic. Družba prejme dividende nakazane na njen transakcijski račun.

- Družba zaradi celoletne uporabe strojne opreme te amortizira. Letna amortizacijska stopnja za njih je $5 \%$.

- Družba kupi in plača s svojega transakcijskega računa še za 20.000 EUR materiala, ki ga porabi pri proizvodnji proizvodov.

- Družba tekom leta najame posojilo/kredit v višini 100.000 EUR, katerega prejme nakazanega na svoj transakcijski račun.

- Družba pred koncem leta plača s svojega transakcijskega računa obresti, ki so 6 $\%$ vrednosti najetega posojila/kredita.

- Družba tekom leta proda in prejme plačilo proizvodov v skupni višini 1.000.000 EUR na svoj transakcijski račun.

\section{Naloge o₹: vprašanja:}

a) Družbeniki četrtemu dopustijo vstop $\mathrm{v}$ družbo po poti povečanja osnovnega kapitala družbe, pri čemer bo imel ta četrti $50 \%$ poslovni delež v družbi. Transakcija se izvrši po knjigovodskih vrednostih poslovnih deležev.

- Koliko znaša osnovni vložek vsakega posameznega družbenika po dokapitalizaciji?

- Koliko mora tretja oseba (četrti družbenik) plačati in komu?

- Opredelite bilanco stanja in izkaz poslovnega izida pred vstopom četrtega družbenika $\mathrm{v}$ družbo in bilanco stanja po tem.

b) Ob koncu leta se velika konkurenčna družba zanima za nakup 50-odstotnega poslovnega deleža v družbi. Po kolikšni ceni naj obstoječi družbeniki ponudijo vstop konkurenčne družbe, da bodo ti družbeniki (A, B in C) med seboj ohranili sorazmerno enako razmerje $\mathrm{v}$ družbi? Transakcija se izvrši na sekundarnem trgu po knjigovodskih vrednostih poslovnih deležev. 


\section{Namig}

- Za pomoč pri reševanju tovrstnih nalog je priporočljivo predelati poglavje 2. 2. z naslovom Povezano spreminjanje gospodarskih kategorij v B. Korošec et al., Osnove računovodstva, Univerza v Mariboru, Ekonomsko-poslovna fakulteta, Maribor, 2016, str. 79-90.

\section{Vsebina / smoter naloge je usvojiti naslednje pojme in problematiko:}

- $\quad$ strošek amortizacije in vpliv tega stroška na poslovni izid.

\section{Rešitev}

Točka A

Izkaz poslovnega izida

\begin{tabular}{|c|c|c|c|}
\hline \multirow[b]{2}{*}{ Stroški amortizacije } & ODHODKI & PRIHODKI & \multirow{3}{*}{$\begin{array}{l}\text { Prihodki od prodaje } \\
\text { proizvodov (prod. vr. } \\
\text { Finančni prihodki (od } \\
\text { prejetih dividend) }\end{array}$} \\
\hline & 5.000 & 1.000 .000 & \\
\hline $\begin{array}{r}\text { Odhodki (stroški porab. } \\
\text { materiala) }\end{array}$ & 20.000 & 3.000 & \\
\hline Odhodki (str. finan.) & 6.000 & & \\
\hline Dobiček >> & 972.000 & & $<<$ Izguba \\
\hline SKUPAJ AKT. STRAN >> & $1 . .003 .000$ & 1.003 .000 & $\begin{array}{l}<<\text { SKUPAJ PAS. } \\
\text { STRAN }\end{array}$ \\
\hline
\end{tabular}

\section{Bilanca stanja (PRED DOKAPITALIZACIJO)}

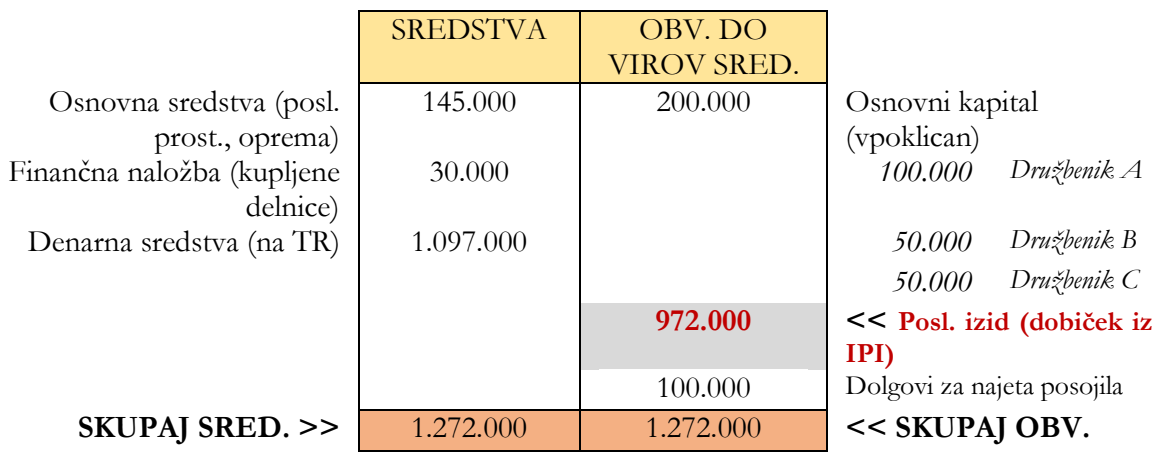


Bilanca stanja (PO DOKAPITALIZACIJI)

\begin{tabular}{|c|c|c|c|c|}
\hline \multirow{3}{*}{$\begin{array}{r}\text { Osnovna sredstva (posl. } \\
\text { prost., oprema) }\end{array}$} & \multirow[b]{2}{*}{ SREDSTVA } & \multirow[b]{2}{*}{$\begin{array}{c}\text { OBV. DO } \\
\text { VIROV SRED. }\end{array}$} & \\
\hline & & & & \\
\hline & 145.000 & \multirow[t]{5}{*}{400.000} & \multicolumn{2}{|c|}{$\begin{array}{l}\text { Osnovni kapital } \\
\text { (vpoklican) }\end{array}$} \\
\hline $\begin{array}{r}\text { Finančna naložba (kupljene } \\
\text { delnice) }\end{array}$ & 30.000 & & 100.000 & Drušbenik. A \\
\hline \multirow[t]{6}{*}{ Denarna sredstva (na TR) } & 2.269 .000 & & 50.000 & Drušbenik B \\
\hline & & & 50.000 & Druश̌benik. C \\
\hline & & & & $\begin{array}{l}\text { Družbenik D } \\
\text { (NOV) }\end{array}$ \\
\hline & & 972.000 & \multirow{4}{*}{\multicolumn{2}{|c|}{$\begin{array}{l}\text { Kapitalske rezerve } \\
<<\text { Posl. izid (dobiček iz } \\
\text { IPI) } \\
\text { Dolgovi za najeta posojila } \\
<<\text { SKUPAJ OBV. }\end{array}$}} \\
\hline & & 972.000 & & \\
\hline & & 100.000 & & \\
\hline SKUPAJ SRED. >> & 2.444 .000 & 2.444 .000 & & \\
\hline
\end{tabular}

\begin{tabular}{|l|c|c|c|}
\hline & $\begin{array}{c}\text { Poslovni } \\
\text { delež } \\
\text { družbenika }\end{array}$ & $\begin{array}{c}\text { Osn. } \\
\text { kapital }\end{array}$ & $\begin{array}{c}\text { Dod. v } \\
\text { kap. rez. }\end{array}$ \\
\hline Družbenik A & 0,2500 & 100.000 & \\
\hline Družbenik B & 0,1250 & 50.000 & \\
\hline Družbenik C & 0,1250 & 50.000 & \\
\hline Družbenik D (NOV) & $\mathbf{0 , 5 0 0 0}$ & $\mathbf{2 0 0 . 0 0 0}$ & $\mathbf{9 7 2 . 0 0 0}$ \\
\hline SKUPAJ & 1,0 & 400.000 & 972.000 \\
\hline
\end{tabular}

\section{Točka B}

Bilanca stanja (PO DOKAPITALIZACIJI)

Osnovna sredstva (posl. prost., oprema) Finančna naložba (kupljene delnice)

Denarna sredstva (na TR)

SKUPAJ SRED.

\begin{tabular}{|c|c|}
\hline SREDSTVA & $\begin{array}{c}\text { OBV. DO } \\
\text { VIROV SRED. }\end{array}$ \\
\hline 145.000 & 200.000 \\
30.000 & \\
1.097 .000 & \\
& 972.000 \\
& 100.000 \\
\hline 1.272 .000 & 1.272 .000 \\
\hline
\end{tabular}

Osnovni kapital

(vpoklican) 50.000 Družbenik. A

25.000 Družbenik B

25.000 Druڤ̌benik $C$

$<$ Posl. izid (dobiček iz IPI)

Dolgovi za najeta posojila

$<$ SKUPAJ OBV. 


\begin{tabular}{|c|l|}
\hline $\begin{array}{r}\text { Izračun } \\
\text { sprem. } \\
\text { posl. del.: }\end{array}$ & $\begin{array}{l}\text { [Potr. } \\
\text { plačilo] }\end{array}$ \\
\hline$-0,2500$ & -293.000 \\
\hline$-0,1250$ & -146.500 \\
\hline$-0,1250$ & -146.500 \\
\hline 0,5000 & \\
\hline 0 & -586.000 \\
\hline
\end{tabular}

Družbenik A

Družbenik B

Družbenik C

Družb. D

(NOV)

SKUPAJ

\begin{tabular}{|c|l|l|l|}
\hline $\begin{array}{l}\text { "Star" OK } \\
\text { (vpokl.) }\end{array}$ & $\begin{array}{l}\text { Izračun } \\
\text { sprem. } \\
\text { OK } \\
\text { (vpok.): }\end{array}$ & $\begin{array}{l}\text { Nov } \\
\text { OK } \\
\text { (vpokl.) }\end{array}$ & $\begin{array}{l}\text { Preverba } \\
\text { ohr. } \\
\text { razmerja: }\end{array}$ \\
\hline 100.000 & -50.000 & 50.000 & 0,5 \\
\hline 50.000 & -25.000 & 25.000 & 0,25 \\
\hline 50.000 & -25.000 & 25.000 & 0.25 \\
\hline & 100.000 & 100.000 & \\
\hline 200.000 & 0 & 200.000 & \\
\hline
\end{tabular}

\section{Vaja D15}

Družbeniki A, B in C so ustanovili d.o.o., in sicer A in B z denarnim vložkom vsak po 10.000 EUR in $\mathrm{C} z$ denarnim vložkom 20.000 EUR.

$\mathrm{Na}$ začetku leta je imela družba naslednjo bilanco stanja: poslovne prostore in opremo v vrednosti 50.000 EUR, terjatve do kupcev v vrednosti 10.000 EUR, zalogo materiala $\mathrm{v}$ vrednosti 5.000 EUR, denarna sredstva na transakcijskem računu $\mathrm{v}$ vrednosti 1.000 EUR, finančne naložbe v delnice v vrednosti 2.000 EUR, dolgove do dobaviteljev v vrednosti 25.000 EUR, obveznosti za izdane menice v višini 3.000 EUR.

Tekom leta so se v družbi zgodili naslednji poslovni dogodki:

- kupci so poravnali svoje dolgove do družbe v višini 5.000 EUR z nakazili na transakcijski račun družbe;

- izdane menice družbe so bile delno unovčene, in sicer v višini 1.000 EUR, za kar je družba izvedba nakazilo s svojega transakcijskega računa;

- družba je delno odplačala dolgove do dobaviteljev v višini 4.000 EUR z nakazilo s svojega transakcijskega računa;

- družba je prodala več kupcem svoje storitve v višini 30.000 EUR; rok plačila je 90 dni, pri čemer do konca leta kupci niso poplačali opravljenih storitev;

- družba je zaradi celoletne uporabe poslovnih prostorov in opreme obračunala amortizacijo, in sicer v vrednosti 10.000 EUR; in 
- družba je pri opravljanju storitev porabila različen material v vrednosti 2.500 EUR, ki ga je imela v zalogi. ${ }^{16}$

Naloge oそ: uprašanja (za odgovore najdite ustrezne pravne podlage):

a) Sestavite začetno bilanco stanja, izkaz poslovnega izida in končno bilanco stanja!

b) Ob koncu leta želi družbenik $\mathrm{C}$ odsvojiti svoj poslovni delež v družbi. Ali lahko preostala družbenika C-ju prepovesta odsvojitev poslovnega deleža? Kako vpliva prenos poslovnega deleža na družbo?

c) Kolikšna je knjigovodska vrednost poslovnega deleža družbenika C?

d) Pod kakšnimi pogoji sme družbenik C svoj poslovni delež odsvojiti osebi D?

e) Družbenik C namerava svoj poslovni delež odsvojiti B-ju. A vztraja, da ima pravico do nakupa polovice poslovnega deleža družbenika C. Ali je njegov zahtevek zakonsko utemeljen?

f) A in B sta ugotovila, da je $\mathrm{C}$ kršil konkurenčno prepoved, zato imata utemeljen razlog za izključitev $\mathrm{C}$-ja iz družbe. Sodišče ugodi njunemu predlogu za izključitev C-ja iz d.o.o. Kakšne so posledice njegove izključitve?

\section{Namig}

- Za pomoč pri reševanju tovrstnih nalog je priporočljivo predelati poglavje 2. 2. z naslovom Povezano spreminjanje gospodarskih kategorij v B. Korošec et al., Osnove računovodstva, Univerza v Mariboru, Ekonomsko-poslovna fakulteta, Maribor, 2016, str. 79-90.

\section{Vsebina / smoter naloge je usvojiti naslednje pojme in problematiko:}

- $\quad$ soglasje preostalih družbenikov za odsvojitev poslovnega deleža osebam, ki niso družbeniki razlog za izstop (7. in 8. odst. 481. člena ZGD-1);

- odsvojitev poslovnega deleža - sprememba »lastniške« strukture v družbi - nespremenljivost sredstev in virov sredstev družbe;

- $\quad$ predkupna pravica družbenikov pri nakupu poslovnega deleža pred drugimi osebami (4. odst. 481. člena ZGD-1);

- $\quad$ pisno obvestilo o nameravani prodaji in pogojih prodaje poslovnega deleža (5. odst. 481. člena ZGD-1);

- $\quad$ razveljavitev notarskega zapisa pogodbe, s katero je bila kršena predkupna pravica (VSL IV Cpg 14372016);

- $\quad$ posledice izključitve družbenika iz d.o.o. (502. člen ZGD-1); izključen je s pravnomočnostjo sodbe, s katero je sodišče ugodilo njegovemu zahtevku za izključitev družbenika (2. točka. 2. odst. 44. Uredbe o vpisu družb in

16 Tovrstne naloge najdete v D. Melavc, A. Novak, Controlling Praktikum, FOV Univerza v Mariboru, 2007, str. 23, 34, 97, 242. 
drugih pravnih oseb v sodni register (Uradni list RS, št. 43/07, 5/10, 25/14, 54/15 in 1/18) - v nadaljevanju Uredba);

- poslovni delež preneha;

- $\quad$ preostali družbeniki morajo prilagoditi kapitalska razmerja v roku treh mesecev - z izključitvijo se namreč osnovni kapital še ne spremeni;

- zmanjšajo osnovni kapital (za znesek nominalne višine osnovnega vložka, ki je prenehal; redno/z umikom/poenostavljeno);

- sorazmerno povečajo obstoječe osnovne vložke - smiselno enako nominalnemu povečanju (osnovnega kapitala) iz sredstev družbe;

- sorazmerno prevzamejo nove osnovne vložke - smiselno enako povečanju osnovnega kapitala z vložki;

- domneva o zmanjšanju osnovnega kapitala - varstvo upnikov - eno leto (520. člen ZGD-1);

- V 6-ih letih je treba izključenemu družbeniku plačati ocenjeno vrednost njegovega poslovnega deleža po stanju ob izključitvi;

- $\quad$ plačilo se lahko opravi šele po vpisu zmanjšanja osnovnega kapitala v register ali po vpisu spremembe določb družbene pogodbe o spremembi poslovnih deležev preostalih družbenikov;

- le v primeru uporabe osnovnega kapitala za izplačilo je treba izpeljati postopek varovanja upnikov - iz nevezanega kapitala se lahko plačilo opravi že prej;

- M. Kocbek, Izplačilo poslovnega deleža - kapitala izstopajočemu družbeniku v d.o.o., Pravna praksa $8 / 2004$, str. 8.

- J. Prostor, Izstop družbenika iz d.o.o., Odvetnik 4/2013, str. 20. 


\section{Rešitev}

Bilanca stanja (začetno stanje)

\begin{tabular}{|c|c|c|c|}
\hline \multirow[b]{2}{*}{$\begin{array}{r}\text { Osnovna sredstva (posl. } \\
\text { prost.) }\end{array}$} & SREDSTVA & $\begin{array}{c}\text { OBV. DO } \\
\text { VIROV SRED. }\end{array}$ & \multirow[b]{2}{*}{ Osnovni kapital (vpoklican) } \\
\hline & 50.000 & 40.000 & \\
\hline $\begin{array}{r}\text { Finančna naložba (kupljene } \\
\text { delnice) }\end{array}$ & 2.000 & & Družbenik $A$ \\
\hline Zaloge materiala & 5.000 & & 10.000 Družbenik B \\
\hline Terjatve do kupcev & 10.000 & & 20.000 Družbenik C \\
\hline Denarna sredstva (na TR) & 1.000 & & \\
\hline & & 25.000 & Dolgovi do dobaviteljev \\
\hline & & 3.000 & $\begin{array}{l}\text { Izdane menice (obv. za izd. } \\
\text { v. p.) }\end{array}$ \\
\hline SKUPAJ SRED. >> & 68.000 & 68.000 & << SKUPAJ OBV. \\
\hline
\end{tabular}

Izkaz poslovnega izida

Odhodki (stroški amortizacije)

\begin{tabular}{|c|c|}
\hline ODHODKI & PRIHODKI \\
\hline 10.000 & 30.000 \\
2.500 & \\
& \\
17.500 & \\
\hline 30.000 & 30.000 \\
\hline
\end{tabular}

Prihodki od prodaje storitev (prod. vr.)

$<$ Izguba

SKUPAJ AKT. STRAN $>>$

\section{Bilanca stanja (končno stanje)}

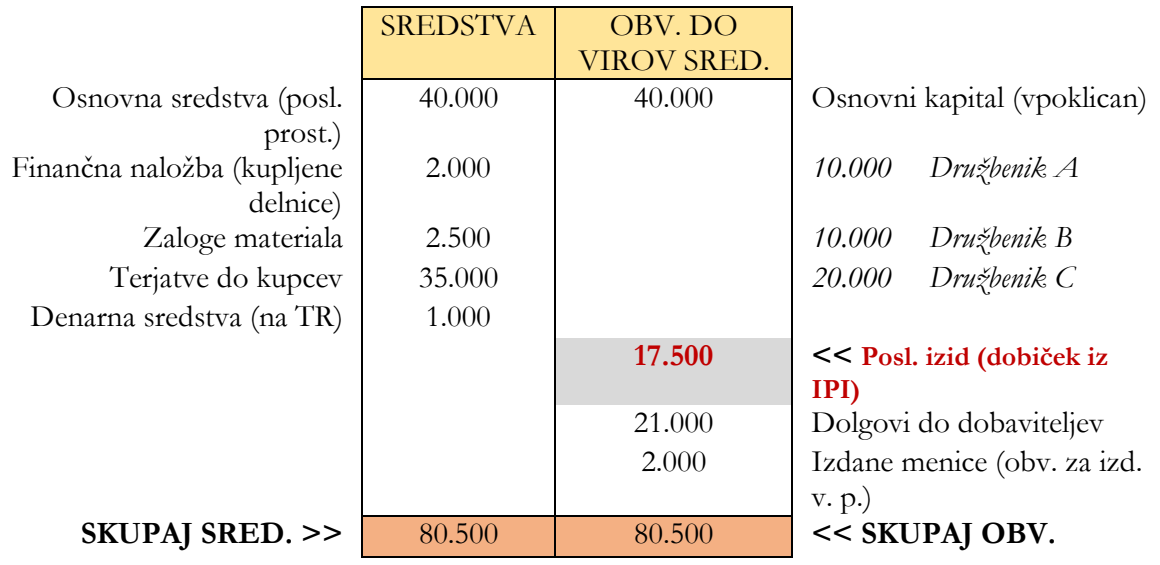




\section{Vaja D16}

Družba z neomejeno odgovornostjo (d.n.o.) je bila preoblikovana v delniško družbo (d.d.). Gospod Kovač je tako v postopku preoblikovanja pridobil pet delnic v nominalni vrednosti $10.000 €$ vsaka. Določen čas po vpisu preoblikovanja v sodni register želi gospod Kovač iz delniške družbe izstopiti, zato od družbe zahteva »izplačilo v delnicah inkorporiranega kapitala v višini $50.000 €$.

\section{Naloge o: vprašanja:}

- Pojasnite, ali je zahtevek gospoda Kovača utemeljen in zakaj!

- Ali (in če, kako) na njegov pravni položaj vpliva okoliščina, da so delnice izdane kot vrednostni papirji? Svetujte mu!

\section{Vsebina / smoter naloge je usvojiti naslednje pojme in problematiko:}

- formalno statusno preoblikovanje;

- posledica izstopa družbenika iz d.n.o. v primerjavi z idejo izstopa iz d.d.;

- inkorporacija korporacijskih pravic v vrednosti papir v d.d. zapovedana (1. odst. 168. člena ZGD-1) - enostaven prenos; v d.o.o. inkorporacija korporacijskih pravic v vrednosti papir prepovedana (3. odst. 471. člena ZGD-1);

- $\quad$ povezava z vpisi družbenikov/delničarjev v sodni register;

- $\quad$ v d.d. ni izstopa (niti sodnega (oziroma zakonskega) iz utemeljenih razlogov niti pogodbenega) kot v d.o.o.;

- možnost zmanjšanja osnovnega kapitala s (prisilnim) umikom delnic v d.d. (381. člen ZGD$1)$;

- $\quad$ izstopu in izključitvi v d.o.o. ne ustrezajo določbe o izstopu/izključitvi manjšinskih delničarjev, saj to transakcijo financira glavni delničar (najmanj $90 \%$ osnovnega kapitala), kar se ne odraža v premoženju družbe; 384. člen ZGD-1 (squeeze out) in 389. člen ZGD-1 (sell out), ne gre za izjemo od prepovedi vračila vložka.

\section{Vaja D17}

Osnovni kapital delniške družbe je 100.000 EUR. Delniška družba je ob ustanovitvi izdala 1.000 delnic. Delniška družba v prvem poslovnem letu ustvari izgubo v višini 40.000 EUR.

\section{Vprašanja:}

- Koliko premoženja ima družba? Koliko znaša knjigovodska vrednost delnice? 
Skupščina delniške družbe po zaključku prvega poslovnega leta sprejme sklep, da se osnovni kapital poveča za 100.000 EUR z izdajo 1.000 delnic druge izdaje, ki se vplaćajo po ceni 60 EUR ra delnico.

\section{Naloga:}

- Pojasnite, ali je takšen sklep v skladu z zakonom!

\section{Vsebina / smoter naloge je usvojiti naslednje pojme in problematiko:}

- prepoved izdaje delnic pod najnižjim emisijskim zneskom (pod nominalnim/pripadajočim zneskom oziroma pod pari); 173. člen ZGD-1;

- načelo zagotovitve osnovnega kapitala - varstvo upnikov;

- $\quad$ takšen sklep je ničen (390. člen ZGD-1);

- takšen sklep bi bil sicer ekonomsko utemeljen, saj ne bi privilegiral obstoječih delničarjev (knjigovodska vrednost njihovih delnic bi se s prihodom novih delničarjev - v slabo novih delničarjev - povečala za 20 EUR), vendar nezakonit zaradi instituta osnovnega kapitala.

\section{Vaja D18}

Osnovni kapital delniške družbe je $100.000 €$. Družba je ob ustanoviti izdala 1.000 delnic z nominalno vrednostjo $100 €$ vsaka. Družba v prvem poslovnem letu ustvari dobiček v višini $40.000 €$. Skupščina po zaključku prvega poslovnega leta sprejme dva sklepa:

sklep št. 1: ves dobiček se razporedi v rezerve,

sklep št. 2: osnovni kapital družbe se efektivno poveča za $100.000 €$ (na skupaj 200.000 €) zizdajo 1.000 delnic druge izdaje z nominalno vrednostjo $100 €$ za delnico. Prednostna pravica delničarjev se izključi.

Naloge oæ: vprašanja:

- Ali je sklep št. 2 v neskladju z zakonom?

- Ali so obstoječi delničarji na kakršenkoli način prikrajšani, če se nove delnice prodajo po njihovi nominalni vrednosti in zakaj?

- Ali bi se kot delničarji te delniške družbe strinjali z izključitvijo prednostne pravice in če, zakaj?

- Na kak način (s katerim institutom korporacijskega prava) je možno doseči, da bi vpisniki delnic zanje plačali ekonomsko primerno ceno in kakšna ta cena je? 


\section{Vsebina / smoter naloge je usvojiti naslednje pojme in problematiko:}

- prednostna pravica delničarjev do vpisa novih delnic (1. odst. 337. člena ZGD-1);

- izključitev prednostne pravice delničarjev do vpisa novih delnic s sklepom o povečanju osnovnega kapitala (3. odst. 337. člena ZGD-1);

- načelo zagotovitve osnovnega kapitala - varstvo upnikov;

- $\quad$ takšen sklep ni ničen, ne ogroža upnikov (390. člen ZGD-1);

- je izpodbojen, saj privilegira nove delničarje v razmerju do obstoječih - $\mathrm{z}$ vložkom 100 EUR bi pridobili delnico, katere knjigovodska vrednost bi znašala 120 EUR (obstoječi delničarji bi bili s prihodom novih delničarjev na slabšem za 20 EUR na delnico);

- poseben izpodbojni razlog v 2. odst. 400. člena ZGD-1.

\section{Vaja D19}

Družba REVIZOR d.o.o. ima enega družbenika z dvema osnovnima vložkoma, ki znašata 2.190,75 EUR in 6.572,25 EUR. Družba poveča osnovni kapital, pri čemer novi družbenik Andrej Sever pridobi $25 \%$ poslovni delež.

\section{Vprašanja:}

- Za koliko se poveča osnovni kapital družbe?

- Ali se družbeniki z družbeno pogodbo lahko dogovorijo, da je novi družbenik upravičen do $95 \%$ deleža pri bilančnem dobičku družbe, nima pa glasovalne pravice $\mathrm{v}$ družbi?

- Koliko glasov ima v tej družbi prvi družbenik in koliko Andrej Sever?

\section{Namig}

- $8.763,00 \ldots 75 \%$

- $\quad$ Andrej Sever ima 58 glasov v družbi. 


\section{Vsebina / smoter naloge je usvojiti naslednje pojme in problematiko:}

- izračun povečanja osnovnega kapitala ob podanih podatkih;

- avtonomija volje družbenikov glede urejanja notranjih razmerji v družbi;

- $\quad$ glede udeležbe na dobičku skladno s 494. členom ZGD-1;

- $\quad$ glede izključitve glasovalne pravice je avtonomija volje praviloma omejena, saj 506. člen ZGD-1 predvideva omejitev glasovalne pravice, kar bi pomenilo, da je ni mogoče v celoti izključiti - primerjaj ureditev v d.d. v 2. odst. 178. in 308. členu ZGD-1;

- nemška sodna praksa dopušča izključitev glasovalne pravice, pri čemer nadomestilo v okviru družbene pogodbe (npr. prednost pri dobičku) pri d.o.o. ni obvezno, vendar bi to lahko nasprotovalo dobri veri in poštenju; ${ }^{17}$

- ne bi bilo dopustno izključiti glasovalne pravice vseh družbenikov, da bi o vseh vprašanjih odločal poslovodja; ${ }^{18}$

- družbeniku bi morala biti zagotovljena pravica glasovanja vsaj o temeljnih vprašanjih o usodni družbe (prenehanje, statusno preoblikovanje, sprememba družbene pogodbe, večje obremenitve družbenikov). ${ }^{19}$

- $\quad$ seštevanje glasov posameznih družbenikov, ki so imetniki več poslovnih deležev, ni dopustno, saj je vsak poslovni delež samostojen (2. odst. 481. člena ZGD-1).

Družbeniki A, B in C so imetniki poslovnih deležev v družbi BETA d.o.o., vsak ima $1 / 3$ poslovni delež.

Družba ima na začetku leta naslednjo bilanco stanja: bančno posojilo v višini 10.000 EUR, denarna sredstva na transakcijskem računu v višini 2.000 EUR, preneseni čisti dobiček v višini 5.000 EUR, osnovna sredstva v višini 15.000 EUR, osnovni kapital $\mathrm{v}$ višini 9.000 EUR, obveznosti za izdane menice v višini 1.000 EUR in terjatve do kupcev v višini 8.000 EUR.

Tekom poslovnega leta je $\mathrm{v}$ družbi prišlo do naslednjih poslovnih dogodkov:

- družba kupi material v vrednosti 1.000 EUR na kasnejše plačilo; do konca leta material dobavitelju ne poplača;

\footnotetext{
${ }^{17}$ B. Zabel v M. Kocbek (redaktor), Veliki komentar Zakona o gospodarskih družbah, druga dopolnjena izdaja z novelami ZGD-1A in ZGD-1H, 2. knjiga, IUS SOFTWARE, GV Založba, Ljubljana, 2014, str. 914-915.

${ }^{18}$ Prav tam, str. 915.

${ }^{19}$ Prav tam.
} 
- družba porabi polovico materiala in proda proizvedene izdelke (iz materiala) po prodajni vrednosti 700 EUR ob takojšnjem plačilu z gotovino (na začetku in koncu obdobja ni nobenih zalog);

- družbi poplačajo kupci njihove obveznosti do družbe v višini 3.000 EUR z nakazili na transakcijski račun družbe;

- $\mathrm{v}$ ponovnem dogovoru z družbo se banka odpove delu terjatve $\mathrm{v}$ zvezi z odobrenim bančnim posojilom v višini 1.000 EUR, ki jo ima banka do družbe;

- družba kupcem odobri naknadni popust v višini 800 EUR,

- družba proda svoje storitve v višini 2.000 EUR na kasnejše plačilo; do konca leta ne prejme poplačila opravljenih storitev; in

- družba zaradi celoletne uporabe osnovnih sredstev obračuna amortizacijo zanje v višini 3.000 EUR.

Naloge o\%: uprašanja (za odgovore najdite ustrezne pravne podlage):

a) Sestavite začetno bilanco stanja, izkaz poslovnega izida in končno bilanco stanja!

b) Koliko znaša osnovni vložek vsakega posameznega družbenika?

c) Če bi se obstoječi družbeniki te družbe, A, B in C (pred spremembo članske strukture) odločili, da likvidirajo družbo, koliko EUR bi v tem primeru prejel vsak od njih? Za katero korporacijsko pravico družbenika gre v tem primeru?

d) Ob koncu leta želi družbenik C odsvojiti svoj poslovni delež v družbi. Kolikšna je knjigovodska vrednost njegovega poslovnega deleža? Ali sme svoj poslovni delež prodati za 500 EUR?

e) Pod kakšnimi pogoji sme družbenik C odsvojiti poslovni delež osebi D?

f) Ali ti pogoji veljajo tudi v primeru, če bi želel $C$ svoj poslovni delež (a) podariti osebi D oziroma (b) bi želel C svoj poslovni delež zamenjati za delnice v neki d.d. z osebo D? Poiščite relevantno sodno prakso!

g) Ali je vpis spremembe družbenika v sodni register konstitutivnega pomena za pridobitev poslovnega deleža?

h) Kdaj lahko novi družbenik D začne izvrševati svoje korporacijske pravice v družbi?

i) Družbenik C odsvoji svoj poslovni delež družbeniku B. Ali sme družbenik B združiti svoja poslovna deleža in če da, pod kakšnimi pogoji? $\mathrm{V}$ čem lahko združitev poslovnih deležev vpliva na B-jev položaj v družbi? 


\section{Namig}

- Za pomoč pri reševanju tovrstnih nalog je priporočljivo predelati poglavje 2. 2. z naslovom Povezano spreminjanje gospodarskih kategorij v B. Korošec et al., Osnove računovodstva, Univerza v Mariboru, Ekonomsko-poslovna fakulteta, Maribor, 2016, str. 79-90.

\section{Vsebina / smoter naloge je usvojiti naslednje pojme in problematiko:}

- na sekundarnem trgu ne velja omejitev »prodaje pod pari« (odsvojitve pod nominalno vrednostjo osnovnega vložka);

- $\quad$ predkupna pravica ostalih družbenikov (5. odst. 481. člena ZGD-1);

- ne velja v primeru darilne ali menjalne pogodbe (VSRS III Ips 69/2003: »/ .../ pri menjalni pogodbi pa cena ni določena in je zato predkupnemu upravičencu nemogoče prodati nepremičnino po isti ceni. Enako je tudi pri sklenitvi mešane menjalno-prodajne pogodbe, saj je pri njej cena le deloma določena v denarju«; VSL I Cpg 1282/2010: »/.../ pritožbeno sodišče ne vidi podlage za presojo, da prednostna pravica velja tudi za prenose, ki ne pomenijo prodaje poslovnega deleža, ampak na primer menjavo; «SL I Cp 2104/2009: »Ker so bili za odsvojitev nepremičnine odločilni osebni elementi med pogodbenima strankama, delno pa je šlo tudi za darilo, zahtevek po 512. čl. OZ ni utemeljen, saj se predkupna pravica lahko uveljavlja le za odsvojitev stvari s čisto prodajno pogodbo.«

- $\quad$ 1. odst. 482. člena ZGD-1 (pred in po spremembi z novelo ZGD-1I);

- N. Plavšak, Vpis družbenika v sodni register tudi po uveljavitvi novele ZGD-1I nima oblikovalnih učinkov za pridobitev poslovnega deleža, Podjetje in delo, št. 2/2016, str. 211;

- drugače VSL IV Cpg 697/2016;

- $\quad$ če družbenik k svojemu poslovnemu deležu pridobi en ali več deležev, ohranijo vsi deleži svojo samostojnost (2. odst. 481. člena ZGD-1; primerjaj tudi 1. odst. 483. člena ZGD-1 in 4. odst. 517. člena ZGD-1); ta ureditev sicer ni kogentna (drugače VSRS III Ips 114/2004);

- $\quad$ v prejšnji alineji navedenih določb ne morejo spremeniti določila 2. točke 1. odst. 43. člena Uredbe (ki je podzakonski predpis in je bil v tem delu do spremembe iz leta $2015 \mathrm{v}$ neskladju z zakonom; pred spremembo Uredbe iz leta 2016 3. točka 1. odst. 43. člena Uredbe);

- po spremembi Uredbe 6. odst. 43. člena določa: »Če družbenik pridobi nov poslovni delež in ga združi s svojim že obstoječim deležem na podlagi sklepa o spremembi družbene pogodbe (akta družbe), je treba s predlogom iz tretjega odstavka tega člena zahtevati, da se v sodni register vpiše tudi ...«;

- VSK Cpg 253/2008;

- družbenik samostojno ( z izjavo) ne more odločati o združitvi več svojih poslovnih deležev, do tega pa lahko pride s spremembo družbene pogodbe (saj ureditev v ZGD-1 ni kogentna);

- $\quad$ razlogi za združitev: ekonomičnost, preglednost, glasovi (glej prejšnjo nalogo);

- vložki za poslovne deleže, ki se združujejo, morajo biti v celoti vplačani in ne sme biti obveznosti naknadnih vplačil, prav tako se lahko združujejo samo poslovni deleži z enakimi upravljavskimi pravicami - izjava družbenika/preverja sodišče samo, saj to izhaja iz družbene pogodbe; R. Gajšek, Združevanje in delitev poslovnih deležev, Podjetje in delo, št. 2/2010, str. 235;

- $\quad$ primerjaj K. A. Kontarščak, Dolžnosti družbenikov in družbe v zvezi s spremembo lastništva poslovnih deležev d.o.o., Pravna praksa, št. 22/2008, str. 6;

- družbenikove premoženjske pravice: udeležba v dobičku;

- $\quad$ prednostna pravica do prevzema novih vložkov (3. odst. 517. člena ZGD-1);

- pravica do likvidacijskega deleža. 


\section{Rešitev}

Bilanca stanja (začetno stanje)

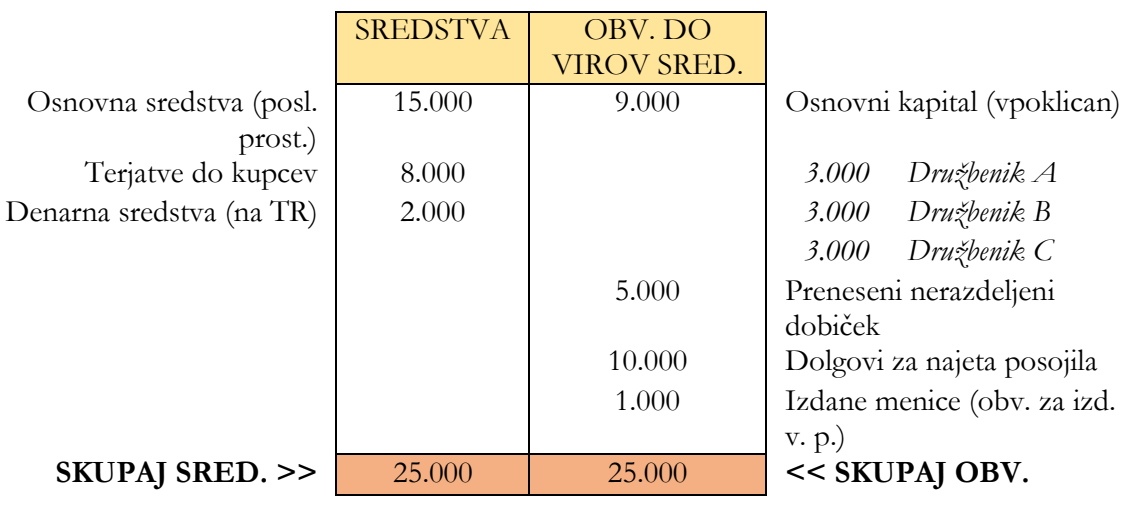

Izkaz poslovnega izida

\begin{tabular}{|c|c|c|c|}
\hline \multirow[b]{2}{*}{ Odhodki (stroški amortizacije) } & ODHODKI & PRIHODKI & \multirow{6}{*}{$\begin{array}{l}\text { Prihodki od prodaje } \\
\text { proizvodov (prod. vr.) } \\
\text { Prihodki od prodaje storitev } \\
\text { (prod. vr.) } \\
\text { Drugi prihodki (odpis dela } \\
\text { obv.) } \\
<<\text { Izguba } \\
<<\text { SKUPAJ PAS. STRAN }\end{array}$} \\
\hline & 3.000 & 700 & \\
\hline $\begin{array}{r}\text { Odhodki (stroški porab. } \\
\text { materiala) }\end{array}$ & 500 & 2.000 & \\
\hline $\begin{array}{r}\text { Drugi odhodki (odobren } \\
\text { popust) }\end{array}$ & 800 & 1.000 & \\
\hline Dobiček >> & & 600 & \\
\hline SKUPAJ AKT. STRAN >> & 3.500 & 3.500 & \\
\hline
\end{tabular}

Bilanca stanja (končno stanje)

\begin{tabular}{|c|c|c|c|}
\hline \multirow{3}{*}{$\begin{array}{r}\text { Osnovna sredstva (posl. } \\
\text { prost.) } \\
\text { Terjatve do kupcev }\end{array}$} & SREDSTVA & $\begin{array}{c}\text { OBV. DO } \\
\text { VIROV SRED. }\end{array}$ & \multirow[b]{2}{*}{ Osnovni kapital (vpoklican) } \\
\hline & 12.000 & \multirow[t]{4}{*}{9.000} & \\
\hline & 6.200 & & 3.000 Družbenik $A$ \\
\hline Denarna sredstva (na TR) & 5.700 & & 3.000 Drušbenik B \\
\hline \multirow{5}{*}{ Zaloga materiala } & 500 & & 3.000 Družbenik C \\
\hline & & 5.000 & \multirow{4}{*}{$\begin{array}{l}\text { Preneseni nerazdeljeni } \\
\text { dobiček } \\
<<\text { Posl. izid (izguba iz IPI) } \\
\text { Dolgovi za najeta posojila } \\
\text { Izdane menice (obv. za izd. } \\
\text { v. p.) } \\
\text { Dolgovi do dobaviteljev } \\
<<\text { SKUPAJ OBV. }\end{array}$} \\
\hline & & -600 & \\
\hline & & $\begin{array}{l}9.000 \\
1.000\end{array}$ & \\
\hline & 24.400 & $\frac{1.000}{24.400}$ & \\
\hline SKUPAJ SRED. >> & & 24.400 & \\
\hline
\end{tabular}




\section{Vaja D21}

Delniška družba ima 500.000 EUR osnovnega kapitala, ki je razdeljen na 200 kosovnih delnic. ${ }^{20}$

\section{Naloge 0₹: uprašanja:}

a) Koliko znaša pripadajoči znesek posamezne delnice $v$ tej družbi?

b) Koliko znaša delež posamezne delnice $v$ osnovnem kapitalu te družbe?

c) Kolikšen je delež korporacijskih pravic, ki jih lahko uresničuje delničar te družbe, ki je imetnik 20 delnic?

d) Družba poveča osnovni kapital za 100.000 EUR. Koliko kosovnih delnic bo izdala?

e) Družba poveča osnovni kapital za 100.000 EUR in izda za ta znesek 25 novih delnic. Ali je to dopustno?

f) Družba ob povečanju osnovnega kapitala izda 100 delnic nove emisije. Za koliko je povečala osnovni kapital?

\section{Vsebina / smoter naloge je usvojiti naslednje pojme in problematiko:}

- izračun pripadajočega zneska kosovne delnice in razmerij med delničarji v d.d., ki je izdala kosovne delnice;

- $\quad$ vsaka kosovna delnica ima enak delež in pripadajoči znesek v osnovnem kapitalu (3. odst. 172. člena ZGD-1;

- $\quad$ zato se mora pri d.d. s kosovnimi delnicami tudi skupno število delnic povečati $\mathrm{v}$ enakem razmerju kot osnovni kapital (2. odst. 333. člena ZGD-1).

\section{Vaja D22}

Družba Beta d.d. je izdala tudi prednostne participativne nevolilne delnice.

\section{Naloge oz: vprašanja:}

a) Ali je v d.d. sploh dopustno omejiti glasovalno pravico?

b) Kolikšen delež imajo takšne delnice lahko v OK?

${ }^{20}$ Glej G. Drnovšek, Kosovne delnice in povečanje osnovnega kapitala, Pravna praksa, št. 12/2014, str. 6. 
c) Kakšno prednost zagotavljajo prednostne participativne delnice?

d) Kakšno prednost zagotavljajo prednostne kumulativne delnice?

e) Družba že dve leti ni izplačala zagotovljene prednosti. Imetnik delnice vas prosi za nasvet, saj meni, da ni pravično, da mu odvzeta glasovalna pravica ne prinaša nobene koristi. Svetujte mu!

f) Ali se lahko kot prednost določi tudi prednostna pravica do dela ostanka premoženja ob likvidaciji ali stečaju družbe?

g) Ali je dopustno izdati delnice, ki bi ob enakem deležu v OK dajale različno število glasov?

\section{Vsebina / smoter naloge je usvojiti naslednje pojme in problematiko:}

- praviloma je v d.d. (drugače kot v d.o.o. - glej 1. odst. 506. člena ZGD-1) dopustno glasovalno pravico samo izključiti (2. odst. 178. člena ZGD-1, razen v primeru iz 1. odst. 308. člena ZGD1 ;

- brez glasovalne pravice se lahko izdajo smo prednostne delnice, vendar družba ne sme imeti več kot polovice tovrstnih delnic v sestavi osnovnega kapitala (2. odst. 178. člena ZGD-1);

- $\quad$ vsaka kosovna delnica ima enak delež in pripadajoči znesek v osnovnem kapitalu (3. odst. 172. člena ZGD-1;

- $\quad$ prednostne participativne delnice - 5. odst. 176. člena ZGD-1;

- prednostne kumulativne delnice - 4. odst. 176. člena ZGD-1;

- če prednost ni izplačana, lahko glas oživi - 2. odst. 315. člena ZGD-1;

- $\quad$ kot prednost se lahko določi tudi prednostna pravica do dela ostanka premoženja ob likvidaciji ali stečaju družbe - 3. odst. 176. člena ZGD-1;

- $\quad$ ni dopustno izdati delnic, ki bi ob enakem deležu v osnovnem kapitalu dajale različno število glasov - 3. odst. 178. člena ZGD-1; 1 glas ali nič, ni omejevanja (na 0,5 ali za določene zadeve) in ni več glasov, ni pravice veta (ni zlatih delnic);

- $\quad$ Kocbek M., Razredi delnic in prednostne delnice, Podjetje in delo, št. 1/2015, str. 5;

- Drnovšek G., Ali ZGD-1 utesnjuje možnost financiranja s prednostnimi delnicami?, Podjetje in delo, št. 3-4/2013, str. 446;

- M. Kocbek et al., Korporacijsko pravo, Pravni položaj gospodarskih subjektov, Druga, dopolnjena in predelana izdaja, GV Založba, Pravna fakulteta Univerze v Mariboru, Ljubljana, 2009, str. 498-501;

- primerjaj N. Plavšak v M. Kocbek (redaktor), Veliki komentar Zakona o gospodarskih družbah, druga dopolnjena izdaja $\mathrm{z}$ novelami ZGD-1A in ZGD-1H, 1. knjiga, IUS SOFTWARE, GV Založba, Ljubljana, 2014, str. 652-657.

- osnovni kapital družbe mora biti vedno razdeljen na razred navadnih delnic, del osnovnega kapitala pa je lahko razdeljen tudi na enega ali več razredov prednostnih delnic (N. Plavšak, nav. delo, str. 652). 


\section{Vaja D23}

Družba je izdala 100 kosovnih delnic, 40 je prednostnih participativnih, prednostna dividenda je 2 EUR na delnico, bilančni dobiček je 10.000 EUR, v družbi so štirje delničarji: A je imetnik 15 prednostnih delnic, B je imetnik 25 prednostnih delnic, C in $\mathrm{D}$ sta imetnika vsak po 30 navadnih delnic.

\section{Naloga:}

- Izračunajte, kako si družbeniki delijo bilančni dobiček! $!^{21}$

\section{Vsebina / smoter naloge je usvojiti naslednje pojme in problematiko:}

- bilančni dobiček se lahko na podlagi teh podatkov deli na štiri možne načine;

- zato je treba način delitve dobička med delničarje zelo natančno določiti v statutu družbe.

\section{Vaja D24}

Novoustanovljena delniška družba ima osnovni kapital razdeljen na 1.000 delnic z nominalnim zneskom $1.000 €$; edini delničar ga je vplačal s 5-odstotno premijo. Po vpisu družbe v sodni register se zgodijo naslednji poslovni dogodki:

- družba kupi pet (5) strojev za predelavo plastične mase v vrednosti $20.000 €$ na stroj, kamion v vrednosti $25.000 €$ ter službeni avtomobil v vrednosti $30.000 €$; vse poplača z nakazili s svojega transakcijskega računa;

- takoj po nakupu avtomobila direktor družbe na službeni poti doživi prometno nesrečo in službeni avtomobil popolnoma razbije, tako da ni več uporaben;

- avtomobil je bil v celoti zavarovan, zato zavarovalnica prizna družbin zahtevek za »totalko«; zavarovalnica nakaže denarna sredstva na transakcijski račun družbe;

- družba kupi potreben material za proizvodnjo izdelkov v vrednosti $10.000 €$, katerega poplača z nakazilo s svojega transakcijskega računa;

${ }^{21}$ Glej G. Drnovšek, Ali ZGD-1 utesnjuje možnost financiranja s prednostnimi delnicami?, Podjetje in delo, št. 3-4/2013, str. 446-457. 
- družba porabi kupljen material za izdelavo izdelkov in zdelane izdelke proda za kupnino v višini $15.000 €$, pri čemer kupci poplačajo kupnino z nakazili na transakcijski račun družbe; ter

- družba je od delničarja najela posojilo v višini $5.000 €$, katerega je delničar nakazal na transakcijski račun družbe.

Naloge oz: vprašanja:

a) Sestavite začetno bilanco stanja, izkaz poslovnega izida in končno bilanco stanja!

b) Koliko znašajo knjigovodska, likvidacijska in tržna vrednost delnice po zaključku prvega poslovnega leta?

\section{Vsebina / smoter naloge je usvojiti naslednje pojme in problematiko:}

- da za izračun knjigovodske vrednosti delnice potrebujemo podatek o lastnem kapitalu; ta podatek nato delimo s številom delnic;

- da je v šolskih nalogah knjigovodska vrednost enaka likvidacijski vrednosti, v poslovni praksi pa lahko pride do razhajanj zaradi vrednotenja postavk v bilanci stanja (npr. nepremičnina se vrednosti po nabavni vrednosti, ki pa odstopa od poštene (tržne) vrednosti);

- za izračun tržne vrednosti nimamo podatkov, saj je ta vedno odvisna od ponudbe in povpraševanja na trgu.

\section{Rešitev}

Izkaz poslovnega izida

\begin{tabular}{|c|c|c|c|}
\hline \multirow{3}{*}{$\begin{array}{r}\text { Odhodki (stroški porab. } \\
\text { materiala) } \\
\text { Odhodki (odpis avta) }\end{array}$} & ODHODKI & PRIHODKI & \multirow{5}{*}{$\begin{array}{l}\text { Prihodki od prodaje } \\
\text { proizvodov (prod. vr.) } \\
\text { Prihodki (zahtevek za } \\
\text { zavarovalnino) } \\
<<\text { Izguba } \\
\text { < S SKUPAJ PAS. STRAN }\end{array}$} \\
\hline & 10.000 & 15.000 & \\
\hline & 30.000 & 30.000 & \\
\hline \multirow{2}{*}{$\begin{array}{l}\text { Dobiček }>> \\
\text { SKUPAJ AKT. STRAN }>>\end{array}$} & 5.000 & & \\
\hline & 45.000 & 45.000 & \\
\hline \multicolumn{4}{|c|}{ Bilanca stanja } \\
\hline \multirow{6}{*}{$\begin{array}{r}\text { Osnovna sredstva } \\
\text { Denarna sredstva (na TR) }\end{array}$} & SREDSTVA & $\begin{array}{l}\text { OBV. DO } \\
\text { VIROV SRED. }\end{array}$ & \multirow{7}{*}{$\begin{array}{l}\text { Osnovni kapital (vpoklican) } \\
1.000 .000 \text { Druð̌benik. } A \\
\text { Kapitalske rezerve } \\
\text { << Posl. izid (izguba iz IPI) } \\
\text { Dolgovi za najeta posojila } \\
<<\text { SKUPAJ OBV. }\end{array}$} \\
\hline & 125.000 & 1.000 .000 & \\
\hline & 935.000 & & \\
\hline & & 50.000 & \\
\hline & & 5.000 & \\
\hline & & 5.000 & \\
\hline SKUPAJ SRED. >> & 1.060 .000 & 1.060 .000 & \\
\hline
\end{tabular}




\section{Vaja D25}

Na podlagi bilance stanja družbe Cigrad d.o.o. za poslovno leto 2010 odgovorite na naslednja vprašanja! Upoštevajte, da ima družba dva poslovna deleža! Osnovni vložek gospoda Vrtačnika znaša 6.387,80 EUR.

\section{Naloge oz: vprašanja:}

a) Koliko znašata poslovna deleža v tej družbi?

b) Drugi poslovni delež je lastni poslovni delež. Ali je takšno stanje v družbi pravno dopustno?

c) Ali gre še vedno za enoosebno d.o.o.?

d) Koliko sta znašali knjigovodski vrednosti poslovnih deležev konec leta 2010?

e) Za koliko bi gospod Vrtačnik prodal svoj poslovni delež v tej družbi dne 31 . 12. 2010 ?

f) Kakšni so pogoji za pridobitev lastnega poslovnega deleža?

g) Kakšna pravna posledica je predvidena, če družba pridobi lastni poslovni delež ob kršitvi zakonskih pogojev za pridobitev poslovnega deleža?

h) Ali je družba ustrezno oblikovala zakonski rezervni sklad (glej podatke iz bilance stanja na dan 31. 12. 2010)?

i) Kaj je navedeno pri družbenikih te družbe v sodnem registru?

j) Kako družba posluje danes?

\begin{tabular}{l}
\hline Kategorije \\
\begin{tabular}{|l|r|r|r|}
\hline \multicolumn{1}{|l|}{ Leto 2010 } & Leto 2009 & Struktura v \% \\
\hline Sredstva & $\mathbf{1 6 . 2 0 0 . 3 4 2}$ & $\mathbf{1 1 . 8 5 3 . 7 9 0}$ & $\mathbf{1 0 0}$ \\
\hline A. Dolgoročna sredstva & 1.403 .003 & 1.639 .186 & 13,8 \\
\hline $\begin{array}{l}\text { I. Neopredmetena sredstva in dolgoročne aktivne } \\
\text { časovne razmejitve }\end{array}$ & 295 & 688 & 0 \\
\hline 1. Neopredmetena sredstva & 295 & 688 & 0 \\
\hline 2. Dolgoročne aktivne časovne razmejitve & 0 & 0 & 0 \\
\hline II. Opredmetena osnovna sredstva & 591.642 & 785.653 & 6,6 \\
\hline $\begin{array}{l}\text { III. Dolgoročne finančne naložbe in Naložbene } \\
\text { nepremičnine }\end{array}$ & 811.066 & 852.845 & 7,2 \\
\hline 1. Naložbene nepremičnine & 747.575 & 783.532 & 6,6 \\
\hline 2. Dolgoročne finančne naložbe & 63.491 & 69.313 & 0,6 \\
\hline IV. Dolgoročne poslovne terjatve & 0 & 0 & 0 \\
\hline V. Odložene terjatve za davek & 0 & 0 & 0 \\
\hline B. Kratkoročna sredstva & 14.796 .412 & 10.212 .543 & 86,2 \\
\hline
\end{tabular}
\end{tabular}




\begin{tabular}{|l|r|r|r|}
\hline I. Sredstva (skupine za odtujitev) za prodajo & 592.817 & 451.918 & 3,8 \\
\hline II. Zaloge & 9.351 .173 & 3.171 .604 & 26,8 \\
\hline III. Kratkoročne finančne naložbe & 1.353 .826 & 1.126 .483 & 9,5 \\
\hline IV. Kratkoročne poslovne terjatve & 3.465 .081 & 5.417 .122 & 45,7 \\
\hline V. Denarna sredstva & 33.515 & 45.416 & 0,4 \\
\hline C. Kratkoročne aktivne časovne razmejitve & 927 & 2.061 & 0 \\
\hline Zunajbilančna sredstva & 6.806 .026 & 4.427 .655 & 37,4 \\
\hline
\end{tabular}

\begin{tabular}{|c|c|c|c|}
\hline Obveznosti do virov sredstev & 16.200 .342 & 11.853 .790 & 100 \\
\hline A. Kapital & 1.693 .010 & 1.485 .450 & 12,5 \\
\hline I. Vpoklicani kapital & 104.323 & 104.323 & 0,9 \\
\hline 1. Osnovni kapital & 104.323 & 104.323 & 0,9 \\
\hline 2. Nevpoklicani kapital (kot odbitna postavka) & 0 & 0 & 0 \\
\hline II. Kapitalske rezerve & 0 & 0 & 0 \\
\hline III. Rezerve iz dobička & 10.432 & 10.432 & 0,1 \\
\hline IV. Revalorizacijske rezerve & 0 & 0 & 0 \\
\hline V. Preneseni čisti poslovni izid & 1.368 .746 & 1.152 .007 & 9,7 \\
\hline VI. Čisti poslovni izid poslovnega leta & 209.509 & 218.688 & 1,8 \\
\hline $\begin{array}{l}\text { B. Rezervacije in dolgoročne pasivne časovne } \\
\text { razmejitve }\end{array}$ & 0 & 0 & 0 \\
\hline C. Finančne in poslovne obveznosti & 14.507 .332 & 10.368 .340 & 87,5 \\
\hline D. Dolgoročne obveznosti & 4.205 .023 & 560.588 & 4,7 \\
\hline I. Dolgoročne finančne obveznosti & 4.205 .023 & 560.588 & 4,7 \\
\hline II. Dolgoročne poslovne obveznosti & 0 & 0 & 0 \\
\hline III. Odložene obveznosti za davek & 0 & 0 & 0 \\
\hline E. Kratkoročne obveznosti & 10.302 .309 & 9.807 .752 & 82,7 \\
\hline I. Obveznosti, vključene v skupine za odtujitev & 27.300 & 0 & 0 \\
\hline II. Kratkoročne finančne obveznosti & 3.438 .185 & 3.601 .400 & 30,4 \\
\hline III. Kratkoročne poslovne obveznosti & 6.836 .824 & 6.206 .352 & 52,4 \\
\hline F. Kratkoročne pasivne časovne razmejitve & 0 & 0 & 0 \\
\hline Zunajbilančne obveznosti & 6.806 .026 & 4.427 .655 & 37,4 \\
\hline
\end{tabular}

Vir: Ajpes - podatkovna zbirka letnih poročil

\section{Vsebina / smoter naloge je usvojiti naslednje pojme in problematiko:}

- $\quad$ pogoji za dopustno pridobitev lastnega poslovnega deleža - 500. člen ZGD-1;

- pridobivanje lastnih poslovnih deležev je urejeno precej manj strogo kot pridobivanje lastnih delnic (247. člen ZGD-1) - tudi premoženje v d.o.o. ni vezano v celoti, temveč samo v višini zneska osnovnega kapitala in vezanih rezerv;

- o pridobitvi in odsvojitvi ne odloča poslovodja, temveč potrebuje soglasje družbenikov, saj pridobitev in odsvojitev lastnega poslovnega deleža spreminja dotedanjo strukturo moči in vpliva v družbi; članske pravice na lastnem poslovnem deležu namreč mirujejo (P. Podgorelec, Ohranjanje osnovnega kapitala pri d.o.o., Podjetje in delo, št. 8/2006, str. 1680);

- prav tako pridobitev lastnega poslovnega deleža $v$ času krize za odsvojitelja učinkuje kot razbremenitev s podjemom povezanega rizika in prevalitev tega na ostale družbenike (P. Podgorelec, nav. delo, str. 1680); 
- predkupna pravica družbenikov pri pridobitvi in odsvojitvi lastnega poslovnega deleža - imajo prednost tudi pred družbo (P. Podgorelec, nav. delo, str. 1680-1681);

- če poslovodja predkupne pravice in zahteve, da o tem odločajo družbeniki, ne upošteva, je pravni posel o pridobitvi ali odsvojitvi poslovnega deleža neveljaven - oseba, ki ve za notranje omejitve ali bi zanje vsaj morala vedeti, se ne more sklicevati na neomejenost pooblastil poslovodje za zastopanje (P. Podgorelec, nav. delo, str. 1681);

- pravne posledice kršitve pogojev za pridobitev lastnih poslovnih deležev: če nima oblikovanih rezerv za lastne poslovne deleže: če družba krši 2. odst. 502. člena ZGD-1 in opravi plačilo, preden oblikuje rezerve, ima družba zoper prejemnika nezakonitega izplačila korporacijski vrnitveni zahtevek (3. odst. 500. člena ZGD-1); gre namreč za kršitev načela ohranjanja osnovnega kapitala; analogna uporaba 4. odst. 247. člena ZGD-1 - ničnost naj pride v poštev samo, če je že ob sklenitvi pravnega posla gotovo, da družba ob izdelavi letnega poročila ne bo sposobna oblikovati rezerv za lastne deleže oz. da družba plačila za pridobitev lastnih poslovnih deležev iz nevezanega premoženja ne bo sposobna izvršiti obligacijski pravni posel je sklenjen pod odložnim pogojem, da bo družba sposobna oblikovati rezerve za lastne deleže; v primeru ničnosti obligacijski pravni posel konkurira s korporacijskim vrnitvenim, vendar je slednji močnejši (P. Podgorelec, nav. delo, str. 1683-1685);

- $\quad$ če za pridobljeni poslovni delež ni v celoti vplačan vložek: obveznost za vplačilo bi zaradi konfuzije prenehala, kar bi pomenilo kršitev načela zagotovitve osnovnega kapitala; tak pravni posel je zaradi kršitve 1. odst. 500. člena ZGD-1 v zvezi s 1. odst. 86. člena OZ ničen, kar velja tako za zavezovalni kot tudi razpolagalni pravni posel; odsvojitelj ostane imetnik poslovnega deleža in s tem tudi nosilec obveznosti za vplačilo še nevplačanega vložka (P. Podgorelec, nav. delo, str. 1682);

če pridobi zadnji poslovni delež - nastop razloga za prenehanje družbe (P. Podgorelec, nav. delo, str. 1681);

- $\quad$ še vedno gre za enoosebno družbo - obvladuje jo ena oseba;

- družbenik družbe, v kateri je imetnica drugega poslovnega deleža družba sama, je ekonomski lastnik celotne družbe - knjigovodska vrednost njegovega poslovnega deleža je lastni kapital družbe;

- zakonski rezervni sklad znaša $10 \%$ osnovnega kapitala in se lahko »nahaja« v prvih treh kategorijah kapitalskih rezerv in v zakonskih rezervah (3. odst. 64. člena ZGD-1); družba ga je ustrezno oblikovala;

- $\quad$ kot imetnik lastnega poslovnega deleža je navedena firma družbe ( $\mathrm{v}$ sodnem registru ni navedeno »lastni poslovni delež«).

\section{Vaja D26}

Družba je kupila lastne delnice v maju in juliju 2019 ter jih delno odtujila v marcu 2020. Z njenimi delnicami se trguje na organiziranem trgu. Del odkupljenih lastnih delnic je družba prodala zaposlenim, preostale je uporabila za izplačilo nagrade poslovodstvu (člani so zaposleni v družbi), in sicer po borznem tečaju. Nakup lastnih delnic: 
- 30.000 delnic po 22 EUR.

Odsvojitev lastnih delnic zaposlenim: 40.000 delnic po 21 EUR.

Uporaba lastnih delnic za nagrado poslovodstva: 10.000 delnic po 19 EUR.

\section{Naloge oz: vprašanja:}

- Kako se ta transakcija odrazi v bilanci stanja?22

\section{Vsebina / smoter naloge je usvojiti naslednje pojme in problematiko:}

- razumevanje računovodske obravnave poslovnega dogodka nakupa lastnih delnic:

- družba za nakup lastnih delnic porabi 1.000.000 EUR denarnih sredstev;

- obenem se na pasivni strani bilance stanja oblikuje odbitna postavka - lastne delnice za 1.000.000 EUR;

- $\quad$ oblikujejo se rezerve za lastne delnice za 1.000.000 EUR, ki se oblikujejo npr. z zmanjšanjem drugih rezerv iz dobička $\mathrm{v}$ tej višini;

- razumevanje računovodske obravnave poslovnega dogodka odsvojitve lastnih delnic zaposlenim:

- družba pridobi 840.000 EUR denarnih sredstev;

- za 800.000 EUR se poveča odbita postavka »lastne delnice« - družba je namreč za delnice povprečno plačala 20 EUR (pridobila je 50.000 lastnih delnic in za njih je skupaj plačala 1.000.000 EUR, kar pomeni, da je v povprečju za delnico plačala 20 EUR);

- $\quad$ za 40.000 EUR se poveča kapitalska rezerva 1. kategorije - lastne delnice kot odbitno postavko odpišemo le za 800.000 EUR, kar smo prejeli več (40.000 EUR), je torej vplačani presežek kapitala za te delnice; ne gre za dobiček, saj se pri nakupu, prodaji, izdaji ali umiku lastnih delnic ne prizna dobiček ali izguba v poslovnem letu, temveč se razlike poračunajo s kapitalom (M. Odar, nav. delo, str. 331);

- $\quad$ sprostijo se rezerve za lastne delnice v višini 800.000 EUR, in sicer ima to pozitiven vpliv na izračun bilančnega dobička - glej 6. odst. 64. člena in 22. točko 5. odst. 66 . člena ZGD-1 - taka rešitev je logična, saj je družba rezerve za lastne delnice oblikovala iz drugih rezerv iz dobička (lahko bi jih npr. tudi iz čistega dobička);

- razumevanje računovodske obravnave poslovnega dogodka uporabe lastnih delnic za nagrado poslovodstva:

- zmanjšajo se kratkoročne obveznosti družbe za plače za 190.000 EUR;

- za 200.000 EUR se poveča odbita postavka »lastne delnice«, saj družba potem nima več lastnih delnic; za delnice je povprečno plačala 20 EUR (pridobila je 50.000 lastnih delnic in za njih je skupaj plačala 1.000.000 EUR, kar pomeni, da je $\mathrm{v}$ povprečju za delnico plačala 20 EUR);

- $\quad$ za 10.000 EUR se zmanjšajo še druge rezerve iz dobička - delnic namreč nimamo več (družba »zapravi 200.000 EUR«), vendar se ji obveznosti zaradi tega zmanjšajo le za 190.000 EUR; zato mora zmanjšati še druge rezerve iz dobička za 10.000 EUR, da bi si lahko privoščila odpisati lastne delnice za 200.000 EUR;

\footnotetext{
${ }^{22}$ Naloga je povzeta po M. Odar v R. Hieng et al., Ponazoritve knjiženj najpogostejših in bolj zapletenih poslovnih dogodkov, IKS: revija za računovodstvo in finance, letn. 35, št. 9/10, Zveza računovodskih in finančnih delavcev Slovenije, Ljubljana, 2008, str. 331.
} 
sprostijo se rezerve za lastne delnice v višini 200.000 EUR, in sicer ima to pozitiven vpliv na izračun bilančnega dobička - glej 6. odst. 64. člena in 22. točko 5. odst. 66. člena ZGD-1 - taka rešitev je logična, saj je družba rezerve za lastne delnice oblikovala iz drugih rezerv iz dobička (lahko bi jih npr. tudi iz čistega dobička).

\section{Rešitev}

Nakup lastnih delnic:

Bilanca stanja

\begin{tabular}{|c|c|c|c|}
\hline \multirow{5}{*}{ Denarna sredstva (na TR) } & SREDSTVA & OBV. DO & \multirow{6}{*}{$\begin{array}{l}\text { Druge rezerve iz dobička } \\
\text { Lastne delnice (kot odbitna } \\
\text { postavka) } \\
\text { Rezerve za lastne delnice } \\
\text { << SKUPAJ OBV. }\end{array}$} \\
\hline & & VIROV SRED. & \\
\hline & \multirow[t]{3}{*}{$-1.000 .000$} & -1.000 .000 & \\
\hline & & -1.000 .000 & \\
\hline & & +1.000 .000 & \\
\hline SKUPAJ SRED. >> & & & \\
\hline
\end{tabular}

Odsvojitev lastnih delnic zaposlenim (po 21 EUR):

Bilanca stanja

\begin{tabular}{|c|c|c|c|}
\hline \multirow{4}{*}{ Denarna sredstva (na TR) } & SREDSTVA & OBV.DO & \multirow{3}{*}{$\begin{array}{l}\text { Kapitalske rezerve } \\
\text { Lastne delnice }\end{array}$} \\
\hline & \multirow{3}{*}{+840.000} & $\frac{\text { VIROV SRED. }}{+40.000}$ & \\
\hline & & $-1.000 .000+$ & \\
\hline & & $\begin{array}{c}+1.000 .000- \\
800.000\end{array}$ & $\begin{array}{l}\text { Rezerve za lastne delnice } \\
\text { obvezno sproščanje v } \\
\text { izračun BD }(+800.000)\end{array}$ \\
\hline SKUPAJ SRED. >> & & & $<$ <KUPAJ OBV. \\
\hline
\end{tabular}

Uporaba lastnih delnic za nagrado poslovodstva:

Bilanca stanja

\begin{tabular}{|c|c|c|c|}
\hline & SREDSTVA & $\begin{array}{c}\text { OBV. DO } \\
\text { VIROV SRED. }\end{array}$ & \multirow{6}{*}{$\begin{array}{l}\text { Kapitalske rezerve } \\
\text { Lastne delnice } \\
\text { Rezerve za lastne delnice ... } \\
\text { obvezno sproščanje v } \\
\text { izračun BD (+200.000) } \\
\text { Obveznosti do poslovodstva } \\
\text { << SKUPAJ OBV. }\end{array}$} \\
\hline & & $\begin{array}{c}+40.000- \\
10.000\end{array}$ & \\
\hline & & $\begin{array}{c}-200.000+ \\
200.000 \\
\end{array}$ & \\
\hline & & $\begin{array}{c}200.000- \\
200.000\end{array}$ & \\
\hline & & -190.000 & \\
\hline SKUPAJ SRED. & & & \\
\hline
\end{tabular}


Vaja D27

Družba ima 100 enot osnovnega kapitala, ki je razdeljen na 10 delnic, kapitalska rezerva 1. kategorije znaša 10 enot in druge rezerve iz dobička 20 enot. Družba pridobi lastno delnico po ceni 13 enot. Sestavite bilanco stanja po nakupu lastne delnice! Nato družba lastno delnico proda za 15 enot.

\section{Naloge oz: vpră̌anja:}

- Sestavite bilanco stanja po odsvojitvi lastne delnice!

- Koliko premoženja ima družba?

\section{Vsebina / smoter naloge je usvojiti naslednje pojme in problematiko:}

- razumevanje računovodske obravnave poslovnega dogodka nakupa lastnih delnic:

- družba ima po nakupu lastne delnice 117 enot premoženja;

- razumevanje računovodske obravnave poslovnega dogodka odsvojitve lastnih delnic:

- družba ima po odsvojitvi lastne delnice 132 enot premoženja;

- $\quad$ sprostijo se rezerve za lastne delnice v višini 13 enot, in sicer ima to pozitiven vpliv na izračun bilančnega dobička - glej 6. odst. 64. člena in 22. točko 5. odst. 66. člena ZGD-1 - taka rešitev je logična, saj je družba rezerve za lastne delnice oblikovala iz drugih rezerv iz dobička. 


\section{Rešitev}

Začetno stanje:

Bilanca stanja

\begin{tabular}{|c|c|c|c|}
\hline \multirow[b]{2}{*}{ Denarna sredstva (na TR) } & SREDSTVA & $\begin{array}{l}\text { OBVEZNOSTI } \\
\text { DO VIROV } \\
\text { SREDSTEV } \\
\end{array}$ & \multirow{3}{*}{$\begin{array}{l}\text { Osnovni kapital } \\
\text { Druge rezerve iz dobička } \\
\text { Kapitalska rezerva } \\
<<\text { SKUPAJ OBV. }\end{array}$} \\
\hline & 130 & $\begin{array}{c}100 \\
20 \\
10\end{array}$ & \\
\hline SKUPAJ SRED. >> & 130 & 130 & \\
\hline
\end{tabular}

Nakup lastnih delnic:

Bilanca stanja

\begin{tabular}{c|c|c|l}
\cline { 3 - 3 } Denarna sredstva (na TR) & SREDSTVA & $\begin{array}{c}\text { OBV. DO } \\
\text { VIROV SRED. }\end{array}$ & \\
\cline { 3 - 4 } & $130-13$ & 100 & Osnovni kapital \\
& & -13 & Lastne delnice \\
& $20-13$ & Druge rezerve iz dobička \\
& & 13 & Rezerve za lastne delnice \\
& & 10 & Kapitalska rezerva \\
SKUPAJ SRED. $>>$ & 117 & $<$ SKUPAJ OBV.
\end{tabular}

Odsvojitev lastnih delnic:

\section{Bilanca stanja}

\begin{tabular}{|c|c|c|c|}
\hline \multirow{5}{*}{ Denarna sredstva (na TR) } & SREDSTVA & OBV. DO & \multirow{6}{*}{$\begin{array}{l}\text { Osnovni kapital } \\
\text { Lastne delnice } \\
\text { Druge rezerve iz dobička } \\
\text { Rezerve za lastne delnice ... } \\
\text { obvezno sproščanje v } \\
\text { izračun BD (+13) } \\
\text { Kapitalska rezerva } \\
<<\text { SKUPAJ OBV. }\end{array}$} \\
\hline & $117+15$ & 100 & \\
\hline & & $-13+13$ & \\
\hline & & 7 & \\
\hline & & $13-13$ & \\
\hline SKUPAJ SRED. >> & 132 & 132 & \\
\hline
\end{tabular}

\section{Vaja D28}

Družba ima naslednjo pasivno stran bilance stanja:

- osnovni kapital (10.000 delnic po 10 EUR =) 100.000 EUR;

- zakonske rezerve 10.000 EUR; 
- kapitalske rezerve 1. kategorije 60.000 EUR;

- druge rezerve iz dobička 100.000 EUR.

Nakup lastnih delnic:

- 800 delnic po 22 EUR;

- 1.200 delnic po 24 EUR.

Skupščina delniške družbe sklene umakniti 2.000 delnic.

\section{Naloge oæ: vprašanja:}

- Kako se ta transakcija odrazi v bilanci stanja?23

\section{Vsebina / smoter naloge je usvojiti naslednje pojme in problematiko:}

- $\quad$ razumevanje računovodske obravnave poslovnega dogodka nakupa lastnih delnic:

- družba za nakup lastnih delnic porabi 46.400 EUR denarnih sredstev;

- obenem se na pasivni strani bilance stanja oblikuje odbitna postavka - lastne delnice za 46.400 EUR;

- oblikujejo se rezerve za lastne delnice za 46.400 EUR, ki se oblikujejo z zmanjšanjem drugih rezerv iz dobička v tej višini (te se zmanjšajo na 53.600 EUR);

- razumevanje računovodske obravnave poslovnega dogodka umika lastnih delnic:

- družba zmanjša osnovni kapital v velikosti zmnožka nominalne vrednosti umaknjenih delnic in njihovega števila (10 EUR x 2.000 delnic = za 20.000 EUR), tj. na 80.000 EUR;

- družba za 20.000 EUR poveča kapitalske rezerve 5. kategorije (zneski na podlagi poenostavljenega zmanjšanja osnovnega kapitala ali zmanjšanja osnovnega kapitala $\mathrm{z}$ umikom deležev);

- za 46.400 EUR se poveča odbita postavka »lastne delnice«, saj te znašajo 0 , družba jih nima več, ker jih umakne;

- $\quad$ za 46.400 EUR se zmanjšajo druge rezerve iz dobička, saj lahko družba lastne delnice umakne poenostavljeno - v breme prostih kategorij lastnega kapitala (3. odst. 381. člena ZGD-1);

- $\quad$ sprostijo se rezerve za lastne delnice v višini 46.400 EUR, in sicer ima to pozitiven vpliv na izračun bilančnega dobička - glej 6. odst. 64. člena in 22. točko 5. odst. 66 . člena ZGD-1 - taka rešitev je logična, saj je družba rezerve za lastne delnice oblikovala iz drugih rezerv iz dobička (lahko bi jih npr. tudi iz čistega dobička).

${ }^{23}$ Naloga je z nekoliko drugačnimi podatki povzeta po M. Odar v R. Hieng et al., Ponazoritve knjiženj najpogostejših in bolj zapletenih poslovnih dogodkov, IKS: revija za računovodstvo in finance, letn. 35, št. 9/10, Zveza računovodskih in finančnih delavcev Slovenije, Ljubljana, 2008, str. 333. 


\section{Rešitev}

Začetno stanje:

Bilanca stanja

\begin{tabular}{|c|c|c|c|}
\hline \multirow[b]{2}{*}{ Denarna sredstva (na TR) } & SREDSTVA & $\begin{array}{l}\text { OBVEZNOSTI } \\
\text { DO VIROV } \\
\text { SREDSTEV }\end{array}$ & \multirow{3}{*}{$\begin{array}{l}\text { Osnovni kapital } \\
\text { Zakonske rezerve } \\
\text { Druge rezerve iz dobička } \\
\text { Kapitalska rezerva } \\
<<\text { SKUPAJ OBV. }\end{array}$} \\
\hline & 270.000 & $\begin{array}{c}100.000 \\
10.000 \\
100.00 \\
60.000\end{array}$ & \\
\hline SKUPAJ SREDSTVA >> & 270.000 & 270.000 & \\
\hline
\end{tabular}

Nakup lastnih delnic:

Bilanca stanja

\begin{tabular}{|c|c|c|c|}
\hline \multirow{8}{*}{ Denarna sredstva (na TR) } & SREDSTVA & OBV.DO & \multirow{8}{*}{$\begin{array}{l}\text { Osnovni kapital } \\
\text { Zakonske rezerve } \\
\text { Lastne delnice } \\
\text { Druge rezerve iz dobička } \\
\text { Rezerve za lastne delnice } \\
\text { Kapitalska rezerva }\end{array}$} \\
\hline & & VIROV SRED. & \\
\hline & \multirow[t]{6}{*}{$\begin{array}{c}270.000- \\
46.400\end{array}$} & 100.000 & \\
\hline & & 10.000 & \\
\hline & & -46.400 & \\
\hline & & $100.00-46.400$ & \\
\hline & & +46.400 & \\
\hline & & 60.000 & \\
\hline SKUPAJ SRED. >> & 223.600 & 223.600 & << SKUPAJ OBV. \\
\hline
\end{tabular}

Umik lastnih delnic:

Bilanca stanja

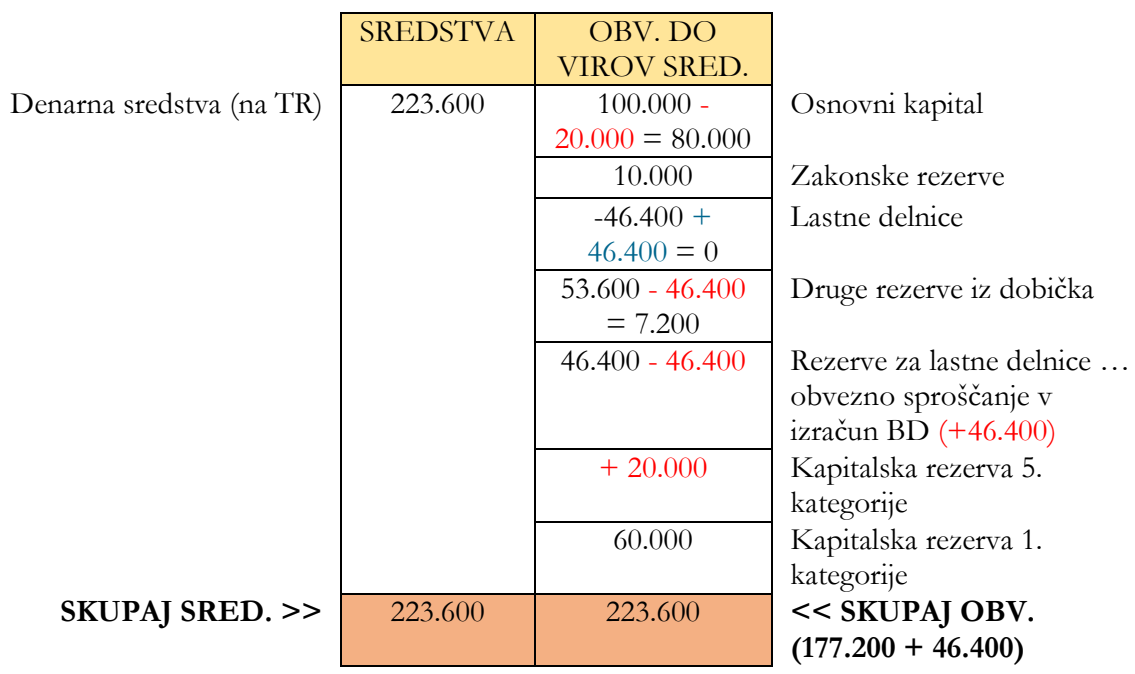


Vaja D29

Družba ima 100 enot osnovnega kapitala, ki je razdeljen na 10 delnic, kapitalska rezerva 1. kategorije znaša 10 enot in druge rezerve iz dobička 40 enot. Družba pridobi lastno delnico po ceni 13 enot. Nato družba umakne lastno delnico.

Naloge oz: vprašanja:

- Koliko premoženja ima družba? Sestavite bilanco stanja po umiku lastne delnice!

\section{Vsebina / smoter naloge je usvojiti naslednje pojme in problematiko:}

- razumevanje računovodske obravnave poslovnega dogodka nakupa lastnih delnic: družba ima po nakupu lastne delnice 137 enot premoženja;

- razumevanje računovodske obravnave poslovnega dogodka umika lastnih delnic:

družba ima po umiku lastne delnice 137 enot premoženja - s to transakcijo nič ne prejme, ničesar ne porabi;

- na pasivni strani bilance stanja se zmanjša znesek osnovnega kapitala, in sicer za nominalni znesek ene delnice, to je za 10 enot;

- $\quad$ za teh 10 enot se povečajo kapitalske rezerve 5. kategorije (zneski na podlagi poenostavljenega zmanjšanja osnovnega kapitala ali zmanjšanja osnovnega kapitala $\mathrm{z}$ umikom deležev);

- $\quad$ za 13 enot se poveča odbita postavka »lastne delnice«, saj te znašajo 0 , družba jih nima več, ker jih umakne;

- $\quad$ za 13 enot se zmanjšajo druge rezerve iz dobička, saj lahko družba lastne delnice umakne poenostavljeno - v breme prostih kategorij lastnega kapitala;

- sprostijo se rezerve za lastne delnice $\mathrm{v}$ višini 13 enot, in sicer ima to pozitiven vpliv na izračun bilančnega dobička - glej 6. odst. 64. člena in 22. točko 5. odst. 66. člena ZGD-1 - taka rešitev je logična, saj je družba rezerve za lastne delnice oblikovala iz drugih rezerv iz dobička (lahko bi jih npr. tudi iz čistega dobička). 


\section{Rešitev}

Začetno stanje:

Bilanca stanja

\begin{tabular}{c|c|c|l}
\cline { 2 - 3 } & SREDSTVA & OBV. DO & \multirow{1}{*}{ OIROV SRED. } \\
\cline { 2 - 3 } Denarna sredstva (na TR) & 150 & 100 & Osnovni kapital \\
& & 40 & Druge rezerve iz dobička \\
& & 10 & Kapitalska rezerva \\
SKUPAJ SRED. >> SKUPAJ OBV. & 150 & $<$
\end{tabular}

Nakup lastnih delnic:

Bilanca stanja

\begin{tabular}{c|c|c|l}
\cline { 2 - 3 } & SREDSTVA & $\begin{array}{c}\text { OBV. DO } \\
\text { VIROV SRED. }\end{array}$ & \multirow{1}{*}{ Osnovni kapital } \\
\cline { 2 - 3 } Denarna sredstva (na TR) & \multirow{2}{*}{$150-13$} & 100 & \\
& & -13 & Lastne delnice \\
& $40-13$ & Druge rezerve iz dobička \\
& +13 & Rezerve za lastne delnice \\
& 10 & Kapitalska rezerva \\
SKUPAJ SRED. >> SKUPAJ OBV. & 137 &
\end{tabular}

Umik lastnih delnic:

Bilanca stanja

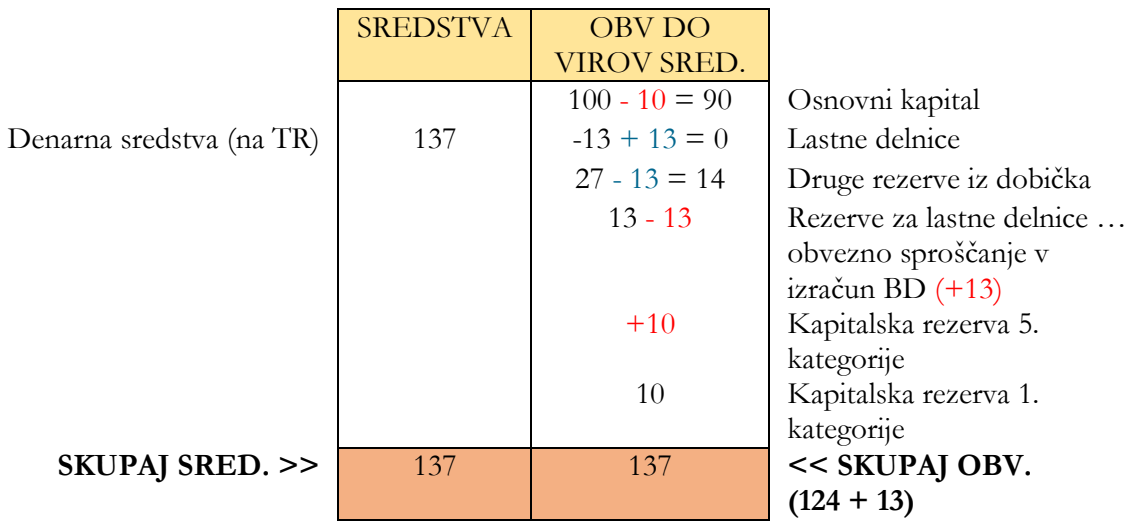




\section{Vaja D30}

Trije družbeniki ustanovijo gospodarsko družbo. Kot osnovni vložek zagotovijo:

- prvi družbenik vplača denarni vložek 5.000 EUR,

- drugi družbenik zagotovi stvarni vložek - lastninsko pravico na poslovnem prostoru, katerega ocenjena vrednost je 40.000 EUR,

- tretji družbenik zagotovi stvarni vložek - lastninsko pravico na pisarniški opremi, katere ocenjena vrednost je 5.000 EUR.

Čez nekaj let drugi družbenik od družbe za 30.000 EUR odkupi poslovni prostor, na trgu pa bi ga družba še vedno lahko prodala za 40.000 EUR. Družba izkazuje 1.000 EUR prostih kategorij kapitala.

\section{Naloge in vprašanja:}

a) Koliko znaša osnovni kapital družbe?

b) Koliko znašajo osnovni vložki in poslovni deleži družbenikov?

c) Ali je nakup poslovnega prostora s strani drugega družbenika veljaven?

d) Ali bi bil odgovor glede veljavnosti pravnega posla o nakupu poslovnega prostora drugačen, če bi imela družba 50.000 EUR prostih kategorij kapitala in bi šlo za d.d.?

e) Družba v tistem letu poslovanja ustvari 1.000 EUR dobička. Kako so družbeniki udeleženi $\mathrm{v}$ dobičku družbe?

\section{Vsebina / smoter naloge je usvojiti naslednje pojme in problematiko:}

- prepoved vračila vložka in pravne posledice kršitve te prepovedi:

v d.o.o. si družbeniki ne smejo izplačati iz premoženja družbe tega, s čimer bi se poseglo v vezani kapital (osnovni kapital in vezane rezerve; 495. člen ZGD-1); $\mathrm{v}$ d.d. si delničarji ne smejo izplačati ničesar - v d.d. je namreč vezano vso premoženje družbe (227. člen ZGD-1, izjema velja v pogodbenem koncernu po 4. odst. 533. člena ZGD-1); predvidenih je še nekaj zakonskih izjem od tega pravila:

- lahko prejmejo plačilo za delnico, ki jo prodajo družbi, če je pridobitev lastne delnice družbe dopustna;

- lahko prejmejo zneske na podlagi zmanjšanja osnovnega kapitala družbe;

- lahko prejmejo izplačila na pravno-poslovni podlagi (na podlagi sklenjenega obligacijskega pravnega posla), vendar samo v primeru, če je pravni posel sklenjen pod tržnimi pogoji;

- lahko prejmejo odpravnino, kadar je tako predvideno po zakonu - npr. pri čezmejni združitvi;

korporacijskopravni vrnitveni zahtevek (233. in 496. člen ZGD-1) - ZGD-1B poudarja, da je močnejši od obligacijskega zahtevka;

- $\quad$ osnovni kapital družbe znaša 50.000 EUR;

- osnovni vložki so navedeni v nalogi, poslovni deleži znašajo: 
prvi družbenik za 5.000 EUR osnovnega vložka pridobi 10-odstotni poslovni delež; drugi družbenik za 40.000 EUR osnovnega vložka pridobi 80-odstotni poslovni delež;

tretji družbenik za 5.000 EUR osnovnega vložka pridobi 10-odstotni poslovni delež;

- nakup poslovnega prostora s strani drugega družbenika ni veljaven, saj je družbenik kršil prepoved vračila vložka; družba je izkazovala le 1.000 EUR prostih kategorij kapitala, zato je z 9.000 EUR posegel v vezano premoženje družbe in mora vrniti poslovni prostor;

- odgovor glede veljavnosti pravnega posla o nakupu poslovnega prostora ne bi bil drugače, če bi imela družba 50.000 EUR prostih kategorij kapitala in bi šlo za d.d., ker je v d.d. vezano vso premoženje družbe - družbenik bi moral vrniti poslovni prostor, saj je z 10.000 EUR posegel v vezano premoženje družbe; ogovor bi bil drugačen, če bi imela družba 50.000 EUR prostih kategorij kapitala in bi šlo za d.o.o., saj v tem primeru ne bi bilo kršitve prepovedi vračila vložka, saj se ne bi poseglo v vezano premoženje družbe;

- če družba v tistem letu poslovanja ustvari 1.000 EUR dobička, bodo družbeniki v dobičku družbe udeleženi glede na svoje poslovne deleže, torej 100, 800, 100 EUR, čeprav je drugi družbenik pravzaprav v družbo prispeval 40.000 EUR in bi se njihovi poslovni deleži delili $12,5 \%, 75 \%$ in $12,5 \%(125,750,125$ EUR); vendar se ne, ker so po zakonu udeleženi sorazmerno; treba je sanirati prepovedano vračilo vložka, vrniti poslovni prostor in s tem zaščititi upnike družbe, pa tudi zagotoviti ustrezno razmerje pri uveljavljanju korporacijskih pravic družbenikov.

\section{Vaja D31}

Družba ABC d.d. se pogaja za najem kredita pri banki BANKA d.d. Družba ABC d.d. ne razpolaga s prostim nepremičnim premoženjem, zato ne more zavarovati kredita. Uprava družbe $\mathrm{ABC}$ d.d. zato predsednika uprave družbe $\mathrm{ABC}$ NEPREMIČNINE d.d. prosi, da za kredit družbe $A B C$ d.d. zastavi svoje proste nepremičnine. BANKA d.d. nato družbi $\mathrm{ABC}$ d.d. odobri kredit, ki ga zavaruje z nepremičninami družbe $A B C$ NEPREMIČNINE d.d. Družba $A B C$ d.d. je v kapitalu družbe ABC NEPREMIČNINE d.d. udeležena s $25 \%$.

\section{Vprašanje:}

- Ali je ustanovljeno zavarovanje veljavno? Poiščite relevantno sodno prakso!

\section{Vsebina / smoter naloge je usvojiti naslednje pojme in problematiko:}

- $\quad$ prepoved vračila vložka in pravne posledice kršitve te prepovedi;

- $\quad$ v d.d. je vezano vso premoženje družbe;

- $\quad$ zagotavljanje zavarovanj d.d. za obveznosti, ki jih ima njen delničar do tretjih = vračilo vložka;

- družba ima zahtevek zoper delničarja, da jo osvobodi te obveze, če zavarovanje še ni uresničeno;

- pogosto delničar banki ne zmore zagotoviti drugega zavarovanja, zato družbe skušajo doseči neveljavnost pravnega posla - ustanovitve zavarovanja za obveznosti delničarja; 
- tudi taka zavarovanja, ki jih družba zagotovi $\mathrm{v}$ korist delničarja, se obravnavajo kot prikrita vračila vložka, če jih družba v nobenem primeru ne bi zagotovila tretji osebi;

- $\quad$ že sama zagotovitev zavarovanja pomeni prepovedano dejanje in ne šele morebitna unovčitev takšnega zavarovanja;

- $\quad$ tudi prevzemanje poroštva za obveznosti delničarja ima namreč ekonomsko enak učinek, to je slabitev realnega premoženja družbe, kot v primeru, če bi družba finančna sredstva neposredno angažirala delničarju v obliki posojila (VSLJ I Cpg 1221/2010 z dne 14. 10. 2010);

- $\quad$ VSRS III Ips 79/2017 z dne 12. 2. 2018;

- VSRS III Ips 115/2016 z dne 13. 6. 2018;

- $\quad$ VSRS III Ips 6/2017 z dne 24. 7. 2018.

\section{Vaja D32}

Trije družbeniki ustanovijo delniško družbo. Osnovni kapital naj bi znašal 30.000 EUR, od česar naj bi A in B zagotovila vsak po 10.000 EUR v gotovini, C pa bi prispeval stvarni vložek. Vendar C ni prepričan, ali je stvarni vložek dejansko vreden 10.000 EUR, hkrati pa ne želi družbe obremeniti s stroški revizije stvarnega vložka. Zato A, B in C sprejmejo odločitev, da C sprva vloži 10.000 EUR v gotovini, takoj po vpisu ustanovitve družbe v sodni register pa naj bi družba od C odkupila »stvarni vložek« za 10.000 EUR.

Mesec dni po vpisu družbe $\mathrm{v}$ sodni register se načrtovana prodaja tudi dejansko realizira in družba od C odkupi sprva nameravani predmet stvarnega vložka. Neposredno za tem ta premet popolnoma zgori v požaru, ki ga povzroči udarec strele. Ker gre za opremo, brez katere družba ne more opravljati svoje dejavnosti, družba posluje z izgubo, zaradi katere je treba predlagati začetek stečajnega postopka.

Kakšne zahtevke ima družba proti C? Ali ima C v razmerju do družbe kakršnekoli nasprotne zahtevke?

\section{Vsebina / smoter naloge je usvojiti naslednje pojme in problematiko:}

- gre za poznavanje instituta poustanovitve;

- določbe veljajo samo za d.d. (ni smiselne uporabe za d.o.o.);

- namen instituta je preprečiti obid določb o stvarnih vložkih (187. člen ZGD-1): statut mora določiti predmet stvarnega vložka, osebo, št. delnic, NZD; če v statutu teh določb ni, je zagotovitev stvarnega vložka neveljavna; če je dogovor neveljaven, mora delničar vplačati emisijski znesek delnic;

- $\quad$ institut poustanovitve je urejen v luči načela zagotovitve in ohranitve $O K$; gre za primere, ko se sklepajo posli z ustanovitelji ali delničarji družbe; 
ti morajo biti v osnovnem kapitalu družbe udeleženi z več kot $10 \%$;

posli se sklepajo v prvih dveh letih po ustanovitvi družbe;

vrednost posla dosega najmanj $10 \%$ osnovnega kapitala;

- $\quad \mathrm{v}$ teh okoliščinah mora biti sklenjena pogodba o poustanovitvi;

- določeni so posebni pogoji za veljavnost pogodbe o poustanovitvi:

soglasje skupščine (kvalificirana večina: $3 / 4$ pri sklepanju zastopanega osnovnega kapitala, če se pogodba sklepa prvo leto, pa $3 / 4$ celotnega osnovnega kapitala);

vpis v sodni register;

- $\quad$ sicer pravni posel ni veljaven;

- pogodba mora biti sklenjena $\mathrm{v}$ pisni obliki, razen če zakon predpisuje strožjo obliko - npr. za poslovni delež pogodbo v obliki notarskega zapisa;

- vsakemu delničarju mora biti omogočeno, da na sedežu družbe pogodbo pregleda, na zahtevo se mu zagotovi prepis pogodbe;

- poslovodstvo mora pripraviti pisno poročilo o pogodbi (zlasti mora razložiti namen pridobitve premoženja);

- $\quad$ pogodbo mora pregledati revizor (194. - 195. člen ZGD-1); ocenjevanje vrednosti podjetja je še posebej zahtevno in drago;

- na podlagi tega mora poročilo pripraviti tudi nadzorni svet;

- na zasedanju skupščine je treba predložiti pogodbo in poročila ter razložiti vsebino pogodbe;

- poslovodstvo mora vložiti predlog za vpis pogodbe v sodni register skupaj s prilogami;

- registrski organ lahko zavrne predlog za vpis, če revizor ugotovi ali je očitno, da je cena za pridobitev premoženja neustrezno visoka (kot bi to lahko ugotovil tudi v tem primeru; prim. 2. odst. 200. člena in 3. odst. 478. člena ZGD-1);

- ne velja za premoženje, ki ga družba pridobi:

- $\quad$ pri rednem poslovanju ali

- na podlagi izvršbe ali

- na organiziranem trgu;

- odškodninska odgovornost členov organov vodenja in nadzora in drugih oseb za škodo, ki nastane družbi zaradi kršitve določb o poustanovitvi;

- postopek je torej smiselno enak kot pri ustanavljanju družbe;

- C bi rad zagotovil manj, kot je obljubil, manj kot 10.000 EUR, še vedno pa bi bil tretjinsko udeležen pri uresničevanju korporacijskih pravic;

- družba lahko zahteva ugotovitev ničnosti pogodbe, s katero je družba od C-ja pridobila podjetje (pravno-dosledno ni treba, ker je pogodba razvezana po samem zakonu, saj je predviden vrnitveni zahtevek po ZGD-1, kar implicira razvezano pogodbo);

- vendar zaradi sodbe VSL I Cp 3270/2013 z dne 9. 4. 2014 jo je bolj smotrno uveljavljati: »Ničnost pravnega posla ne učinkuje sama po sebi. Nični posli dejansko učinkujejo. Učinkujejo dokler njihova ničnost ni ugotovljena. Zato šele z ugotovitvijo, da je posel ničen, nastanejo povračilni zahtevki. Če temu ne bi bilo tako, ne bi bilo nobene potrebe po zakonskem določilu o nezastarljivosti pravice do uveljavljanja ničnostik;

- pravna posledica je vrnitveni zahtevek družbe po 233. členu ZGD-1 - družba zahteva nazaj kupnino v višini 10.00 EUR, družbenik pa ima obligacijski zahtevek za vrnitev stvarnega vložka, ki ga več ni; družba bi morala v skladu s pravili obligacijskega prava nadomestiti vrednost dosežene koristi; C bi kot stečajni upnik s terjatvijo za 10.000 EUR konkuriral z drugimi upniki stečajnega dolžnika na stečajni masi in bi bil sorazmerno poplačan; družba prejme 10.000 EUR v celoti, saj je korporacijski zahtevek močnejši od obligacijskega zahtevka in v stečaju ni pobotanja. 


\section{Vaja D33}

Poslovodstvo družbe $\mathrm{A}$ in poslovodstvo družbe $\mathrm{B}$ razmišljata o pripojitvi ene družbe k drugi. Družbi nista kapitalsko povezani.

Naloge oz: vprašanja:

a) Opišite potek pripojitve - od ideje o pripojitvi do zaključka pripojitve (ob tem zanemarite interese upnikov)!

b) Katero načelo je bistvenega pomena pri materialnih statusnih preoblikovanjih za družbenike udeleženih družb?

c) Izračunana je bila ekonomska vrednost družbe A, tj. 1.000.000 EUR. Izračunana je bila ekonomska vrednost družbe B, tj. 500.000 EUR. Ali lahko iz tega podatka sklepate, katera družba se je pripojila h kateri družbi?

d) Predpostavite, da se družba $\mathrm{B}$ pripoji $\mathrm{k}$ družbi $\mathrm{A}$ in menjalno razmerje ni ustrezno določeno. Ali je družba A pridobila protipravno premoženjsko korist?

e) Funkcija denarnih doplačil (580. člen). Zakaj omejitev na $10 \%$ ?

f) Menjalno razmerje ni bilo ustrezno določeno. Ali je mogoče, da je bilo določeno v škodo družbenikov prevzemne družbe in če je, ali je za tak položaj predvideno varstvo?

g) Družbi $A$ in $B$ nista javni družbi. $V$ družbi $B$, ki je organizirana $v$ pravnoorganizacijski obliki d.d., se je leto dni pred pripojitvijo vršila izključitev manjšinskih delničarjev iz družbe. Ali višina izplačila posameznemu izključenemu delničarju kakorkoli vpliva na določitev menjalnega razmerja?

h) Družbi $A$ in $B$ nista javni družbi. $V$ družbi $B$, ki je organizirana $v$ pravnoorganizacijski obliki d.d., je imela uprava družbe pooblastilo za odkup lastnih delnic. Ali cena, po kateri bi lahko uprava odkupila lastne delnice, kakorkoli vpliva na določitev menjalnega razmerja?

i) Kako je $\mathrm{v}$ zakonu urejeno določanje vrednosti udeleženih družb za namene izračuna menjalnega razmerja? 


\section{Vsebina / smoter naloge je usvojiti naslednje pojme in problematiko:}

- pripojitev kot oblika materialnega statusnega preoblikovanja, in sicer združitve;

- $\quad$ pri pripojitvi ena od udeleženih družb preneha;

- postopek odločanja o pripojitvi je primerljiv z odločanjem o ustanovitvi, povečanju osnovnega kapitala, poustanovitvi;

- poslovodstva družb, ki se združujejo, morajo skleniti pogodbo o pripojitvi (1. odst. 581. člena ZGD-1);

- poslovodstvo vsake udeležene družbe, mora izdelati podrobno pisno poročilo o pripojitvi; poročilo je lahko skupno (582. člen ZGD-1);

- pogodbo o pripojitvi mora pregledati pripojitveni revizor za vsako posamezno družbo; imenuje ga sodišče na predlog nadzornega sveta vsake posamezne družbe; s soglasjem nadzornih svetov udeleženih družb lahko revizijo opravi en revizor za vse družbe (583. člen ZGD-1);

- $\quad$ revizor mora izdelati pisno poročilo o reviziji pripojitve (583. člen ZGD-1);

- nadzorni svet vsake družbe mora na podlagi poročila poslovodstva in revizorjevega poročila pregledati nameravano pripojitev ter izdelati pisno poročilo (584. člen ZGD-1);

- $\quad$ za veljavnost pogodbe je potrebno soglasje skupščine vsake udeležene družbe skupščina lahko da soglasje pred sklenitvijo pogodbe ali po tem; kvalificirana večina: najmanj $3 / 4$ pri sklepanju zastopanega osnovnega kapitala (585. člen ZGD-1);

- poslovodstvo vsake družbe mora vsaj mesec dni pred zasedanjem skupščine, ki bo odločala o soglasju za pripojitev, registrskemu organu predložiti pogodbo o pripojitvi, ki jo je prej pregledal nadzorni svet družbe; družba mora objaviti obvestilo o predložitvi pogodbe registrskemu organu (1. odst. 586. člena ZGD-1);

- delničarjem je treba vsaj mesec dni pred zasedanjem skupščine na sedežu družbe omogočiti pregled pogodbe o pripojitvi, letnih poročil udeleženih družb za zadnja tri poslovna leta, zaključnih poročil, vmesnih bilanc stanja, poročil poslovodstva, revizorjevih poročil in poročil nadzornih svetov (2. odst. 586. člena ZGD-1);

- na zasedanju skupščine mora poslovodstvo ustno razložiti vsebino pogodbe o pripojitvi (8. odst. 586. člena ZGD-1);

- povečanje osnovnega kapitala zaradi pripojitve mora pregledati revizor; revizijo lahko opravi tudi pripojitveni revizor (3. in 4. odst. 588. člena ZGD-1);

- poslovodstvo vsake udeležene družbe mora vložiti predlog za vpis pripojitve v sodni register po sedežu prevzemne družbe (590. člen ZGD-1);

- $\quad$ registrski organ po sedežu prevzemne družbe $\mathrm{v}$ register hkrati vpiše pripojitev vseh prevzetih družb prevzemni družbi; če je prevzemna družba povečala osnovni kapital, se vpiše povečanje osnovnega kapitala hkrati s pripojitvijo (591. člen ZGD1);

- $\quad$ za družbenike je bistvenega pomena načelo nespremenjenega premoženjskega položaja;

- $\quad$ iz tega, koliko je katera od udeleženih družb ekonomsko vredna, ne moremo ugotoviti, katera družba je prevzemna in katera prevzeta;

- če menjalno razmerje ni določeno ustrezno, s tem prevzeta ali prevzemna družba ne pridobita protipravne premoženjske koristi, temveč jo pridobijo družbeniki ene ali druge družbe na račun družbenikov ene ali druge družbe;

- denarna doplačila so omejena na $10 \%$ skupnega najmanjšega emisijskega zneska delnic, ki jih prevzemna družba zagotovi delničarjem prevzete družbe zaradi pripojitve (5. odst. 580. člena ZGD-1); omejitev je v funkciji prepovedi vračila vložka gre za share deal;

- možno je, da je menjalno razmerje določeno neustrezno, in sicer $\mathrm{v}$ škodo družbenikov prevzemne družbe; predvideno varstvo je sodni preizkus menjalnega razmerja po 605. členu ZGD-1;

- postopek izključitve manjšinskih družbenikov $\mathrm{v}$ eni od udeleženih družb leto dni pred pripojitvijo ne vpliva na pripojitev; čeprav je v 386. členu ZGD-1 določena smiselna uporaba 
določb o reviziji pripojitve (583. člen ZGD-1), je pomembno upoštevati namen in obdobje vrednotenja družb, zato denarna odpravnina, ki je bila določena za manjšinske delničarje, nima vpliva na določanje menjalnega razmerja pri pripojitvi, podrobneje na ekonomsko vrednost družbe, v kateri se je vršila izključitev manjšinskih delničarjev;

- $\quad$ enako velja za ceno, določeno v pooblastilu za odkup lastnih delnic (8. alineja 1. odst 247. člena ZGD-1 določa, da mora biti določena v pooblastilu) - ne vpliva na določitev menjalnega razmerja - pomembna sta namen in obdobje vrednotenja družbe;

- $\quad$ v zakonu ni urejeno določanje vrednosti udeleženih družb za namene izračuna menjalnega razmerja - določeno je samo to, da mora biti menjalno razmerje primerno (pravni standard) natančneje: zagotovitev delnic po menjalnem razmerju in višina morebitnih denarnih doplačil ali ponujena odpravnina morajo biti primerno nadomestilo za delnice prevzete družbe;

- $\quad$ metode ocenjevanja vrednosti podjemov:

metoda poštene tržne vrednosti - nujen je obstoj primerljivih prodaj v relevantnem obdobju na relevantnem trgu;

metoda čiste vrednosti sredstev (premoženjski položaj podjema $\mathrm{v}$ določenem časovnem trenutku);

- metoda diskontiranih prihodnjih donosov je dinamična metoda, ki upošteva sposobnost podjemov $\mathrm{v}$ prihodnosti ustvarjati donose (delujoči podjem) - je najprimernejša za določitev primernega menjalnega razmerja. ${ }^{24}$

\section{Vaja D34}

Družba ima 100.000 EUR osnovnega kapitala in enega družbenika, ki je poslovni delež vplačal z 10-odstotno premijo. Po vpisu družbe v sodni register se v družbi zgodijo naslednji poslovni dogodki:

- družba kupi stroja, ki ju uporablja za proizvodnjo pri svoji dejavnosti, v vrednosti 30.000 EUR in 25.000 EUR; oboje družba poplača z nakazili s svojega transakcijskega računa; in

- družba kupi potreben material za proizvodnjo izdelkov v vrednosti 15.000 EUR; material je kupljen na kasnejše plačilo in ni poplačan do konca leta;

- družba ustanovi hčerinsko družbo (s $100 \%$ poslovnim deležem) z osnovnim vložkom 20.000 EUR;

- družba pri proizvodnji izdelkov porabi ves kupljen material in izdelane izdelke proda kupcem v vrednosti 20.000 EUR, in sicer na kasnejše plačilo;

- družbi kupci do konca leta poplačajo 5.000 EUR njihovih obveznosti do družbe z nakazili na transakcijski račun družbe;

\footnotetext{
${ }^{24}$ N. Plavšak v M. Kocbek (redaktor), Veliki komentar Zakona o gospodarskih družbah, druga dopolnjena izdaja z novelami ZGD-1A in ZGD-1H, 3. knjiga, IUS SOFTWARE, GV Založba, Ljubljana, 2014, str. 194-195.
} 
- družba zaradi celoletne uporabe sredstev obračuna še amortizacijo, in sicer za prvi stroj v višini $5 \%$ vrednosti stroja in za drugi stroj (kupljen za 25.000 EUR) $\mathrm{v}$ višini $10 \%$ vrednosti; ter

- družba izvede pripojitev hčerinske družbe (ki od trenutka ustanovitve dalje ni nič poslovala) k sebi.

\section{Naloge o₹: uprašanja:}

a) $\mathrm{V}$ čem je razlog vplačila s premijo?

b) Sestavi začetno in končno bilanco stanja te družbe pred dogodkom pripojitve hčerinske družbe obvladujoči družbi.

c) Kako se izvede pripojitev hčerinske družbe in kakšne so posledice te pripojitve?

\section{Namig}

- Za pomoč pri reševanju tovrstnih nalog je priporočljivo predelati poglavje 2. 2. z naslovom Povezano spreminjanje gospodarskih kategorij v B. Korošec et al., Osnove računovodstva, Univerza v Mariboru, Ekonomsko-poslovna fakulteta, Maribor, 2016, str. 79-90.

\section{Vsebina / smoter naloge je usvojiti naslednje pojme in problematiko:}

- pridobitev poslovnega deleža v družbi oz. ustanovitev družbe le spremeni strukturo premoženja družbe, in sicer imamo v bilanci stanja namesto 20.000 EUR denarnih sredstev, ki se za toliko zmanjšajo, 20.000 EUR vredno dolgoročno finančno naložbo;

- družba mora skladno s 3. odst. 64. člena ZGD-1 oblikovati zakonski rezervni sklad (tj. $10 \%$ osnovnega kapitala); če ob ustanovitvi vplača $10 \%$ osnovnega kapitala v kapitalsko rezervo 1. kategorije, je s tem izpolnila to svojo obveznost in ji ni treba vsako leto odvajati $5 \%$ čistega dobička v zakonske rezerve, kot se sicer zahteva skladno s 4. odst. 64. člena ZGD-1, vse dokler ne bi zapolnila zakonskega rezervnega sklada; že prvo poslovno leto, če ustvari čisti dobiček, ga lahko uporabi za izplačila družbenikom;

- pripojitev družbe hčere $\mathrm{k}$ družbi materi (upstream merger) se izvede, ne da bi se povečal osnovni kapital družbe matere - prevzemna družba ne sme zagotoviti delnic oz. poslovnih deležev sama sebi (1. točka 1. odst. 589. člena ZGD-1). 


\section{Rešitev}

Izkaz poslovnega izida

\begin{tabular}{|c|c|c|c|}
\hline & ODHODKI & PRIHODKI & \\
\hline Stroški amortizacije & 4.000 & 20.000 & $\begin{array}{l}\text { Prihodki od prodaje } \\
\text { proizvodov (prod. vr.) }\end{array}$ \\
\hline $\begin{array}{r}\text { Odhodki (storški porab. } \\
\text { materiala) }\end{array}$ & 15.000 & & \\
\hline Dobiček >> & 1.000 & & $<<$ Izguba \\
\hline SKUPAJ AKT. STRAN >> & 20.000 & 20.000 & $<<$ SKUPAJ PAS. STRAN \\
\hline
\end{tabular}

Bilanca stanja (PRED PRIPOJITVIJO)

\begin{tabular}{|c|c|c|c|}
\hline & SREDSTVA & $\begin{array}{c}\text { OBV. DO } \\
\text { VIROV SRED. }\end{array}$ & \multirow{3}{*}{$\begin{array}{l}\text { Osnovni kapital (vpoklican) } \\
100.000 \text { Drušbenik A }\end{array}$} \\
\hline Osnovna sredstva & 51.000 & 100.000 & \\
\hline $\begin{array}{r}\text { Finančna naložba (hčer. } \\
\text { družba) }\end{array}$ & 20.000 & & \\
\hline Terjatve do kupcev & 15.000 & 10.000 & \multirow{4}{*}{$\begin{array}{l}\text { Kapitalske rezerve } \\
<<\text { Posl. izid (dobiček iz IPI) } \\
\text { Dolgovi do dobaviteljev } \\
<<\text { SKUPAJ OBV. }\end{array}$} \\
\hline Denarna sredstva (na TR) & 40.000 & 1.000 & \\
\hline & & 15.000 & \\
\hline SKUPAJ SRED. >> & 126.000 & 126.000 & \\
\hline
\end{tabular}

Bilanca stanja (PO PRIPOJITVI)

\begin{tabular}{|c|c|c|c|}
\hline & SREDSTVA & $\begin{array}{c}\text { OBV. DO } \\
\text { VIROV SRED. }\end{array}$ & \\
\hline Osnovna sredstva & 51.000 & 100.000 & Osnovni kapital (vpoklican) \\
\hline $\begin{array}{r}\text { Finančna naložba (hčer. } \\
\text { družba) }\end{array}$ & 0 & & 100.000 Družbenik $A$ \\
\hline Terjatve do kupcev & 15.000 & 10.000 & Kapitalske rezerve \\
\hline Denarna sredstva (na TR) & 60.000 & 1.000 & $<<$ Posl izid (dobiček iz IPI) \\
\hline & & 15.000 & Dolgovi do dobaviteljev \\
\hline SKUPAJ SRED. >> & 126.000 & 126.000 & $<<$ SKUPAJ OBV. \\
\hline
\end{tabular}




\section{Vaja D35}

Dva družbenika ustanovita družbo TRANSPORT d.d. Vpišeta vsak po 250 kosovnih delnic s pripadajočim zneskom 1.000 EUR. Prvi družbenik vplača vpisane delnice s 5-odstotno premijo; drugi ne. Po ustanovitvi družbe se zgodijo v družbi naslednji poslovni dogodki:

- družba TRANSPORT d.d. ustanovi hčerinski družbi PREVOZI d.o.o. z denarnim vložkom 50.000 EUR in LOGISTIKA d.d. z denarnim vložkom 50.000 EUR;

- čez 2 meseca se družba PREVOZI d.o.o. pripoji k družbi LOGISTIKA d.d., ki zaradi izvedbe pripojitve ne poveča osnovnega kapitala.

\section{Naloge oz: vprašanja:}

a) Ali bi morala družba LOGISTIKA d.d. zaradi pripojitve povečati osnovni kapital in delnice zagotoviti družbenikom prevzete družbe?

b) Napišite zaključno bilanco stanja družbe TRANSPORT d.d., pri čemer natančno pojasnite sestavo njenega premoženja!

\section{Vsebina / smoter naloge je usvojiti naslednje pojme in problematiko:}

- povečanje osnovnega kapitala v tem primeru ni nujno;

- $\quad$ pripojitev družbe $\mathrm{k}$ družbi sestri (sidestream merger) se izvede, ne da bi bilo treba povečati osnovni kapital prevzemne družbe - prevzemna družba lahko zagotovi delnice družbenikom prevzete družbe ali ne (1. točka 2. odst. 589. člena ZGD-1;

- razlika:

če družba Logistika d.d. poveča osnovni kapital in izda nove delnice za družbo Transport d.d. (kot protidajatev zaradi prenehanja udeležbe v družbi Prevozi d.o.o.), je družba Transport d.d. imetnica večjega števila delnic družbe Logistika d.d.;

če pa družba Logistika d.d. ne poveča osnovnega kapitala in ne izda novih delnic, so obstoječe delnice družbe Logistika d.d., katerih imetnica je družba Transport d.d., vredne toliko več. 


\section{Rešitev}

\section{Bilanca stanja (PRED PRIPOJITVIJO)}

\begin{tabular}{|c|c|c|c|}
\hline & SREDSTVA & $\begin{array}{c}\text { OBV. DO } \\
\text { VIROV SRED. }\end{array}$ & \multirow[b]{2}{*}{ Osnovni kapital (vpoklican) } \\
\hline $\begin{array}{r}\text { Finančna naložba (hčer dr. } \\
\text { PREVOZI) }\end{array}$ & 50.000 & 500.000 & \\
\hline $\begin{array}{l}\text { Finančna naložba (hčer. dr. } \\
\text { LOGISTIKA) }\end{array}$ & 50.000 & & 250.000 Druǎbenik $A$ \\
\hline Denarna sredstva (na TR) & 412.500 & 12.500 & $\begin{array}{l}250.000 \text { Druø̌benik B } \\
\text { Kapitalske rezerve }\end{array}$ \\
\hline SKUPAJ SRED. >> & 512.500 & 512.500 & $\begin{array}{l}\text { Kapitalske rezerve } \\
<<\text { SKUPAJ OBV. }\end{array}$ \\
\hline
\end{tabular}

Bilanca stanja (PO PRIPOJITVI)

\begin{tabular}{|c|c|c|c|}
\hline & SREDSTVA & OBV. DO & \multirow[b]{2}{*}{ Osnovni kapital (vpoklican) } \\
\hline $\begin{array}{r}\text { Finančna naložba (hčer dr. } \\
\text { PREVOZI) }\end{array}$ & 0 & 500.000 & \\
\hline $\begin{array}{l}\text { Finančna naložba (hčer. dr. } \\
\text { LOGISTIKA) }\end{array}$ & 100.000 & & 250.000 Družbenik $A$ \\
\hline Denarna sredstva (na TR) & 412.500 & 12.500 & $\begin{array}{l}250.000 \text { Družbenik B } \\
\text { Kapitalske rezerve }\end{array}$ \\
\hline SKUPAJ SRED. >> & 512.500 & 512.500 & $<<$ SKUPAJ OBV. \\
\hline
\end{tabular}

(Opomba: vrednost FN se poveča zaradi »sidestream merger« hčerinske družbe k drugi).

Bilančno izkazovanje pri LOGISTIKA d.o.o.:

VAR. A:

\begin{tabular}{|l|r|}
\hline Denar & 100.000 \\
\hline OK & 50.000 \\
\hline $\begin{array}{l}\text { KAP - } \\
\text { »resežek«» }\end{array}$ & 50.000 \\
\hline
\end{tabular}

VAR. B:

\begin{tabular}{|l|l|}
\hline Denar & 100.000 \\
\hline OK & 100.000 \\
\hline
\end{tabular}

Vaja D36

Družba Mizar Petre d.n.o. in družba Modno oblikovanje Praznik d.n.o. razmišljata o združitvi družb.

Vprašanje:

- Kako bi svetovali v tej zadevi? 
Vsebina / smoter naloge je usvojiti naslednje pojme in problematiko:

- dopustno je tudi združevanje osebnih družb (639. člen ZGD-1);

- $\quad$ pomembno je, da sta za sklep o združitvi potrebni soglasje osebno odgovornih družbenikov v osebni družbi in soglasje družbenikov v kapitalski družbi, ki bodo po združitvi odgovorni za obveznosti družbe z vsem svojim premoženjem.

\section{Vaja D37}

Leon Petre s.p. želi preoblikovati svoje podjetje po poti oddelitve na novo družbo.

\section{Vprašanje:}

- Svetujte mu!

\section{Vsebina / smoter naloge je usvojiti naslednje pojme in problematiko:}

- takšno preoblikovanje pojmovno ni mogoče, saj s.p. nima članske strukture, zato se takšno preoblikovanje izvede po poti izčlenitve (668. - 673. a člen ZGD-1).

\section{Vaja D38}

Pri razdelitvi je udeleženih 5 družb (A, B, C, ¿̌ in D), vse so prejele okoli milijon neto premoženja. Obveznost X v višini 100.000 EUR je z delitvenim načrtom dodeljena družbi A.

\section{Vprašanje:}

- Ali lahko upnik to obveznost izterja od družbe B?

\section{Vsebina / smoter naloge je usvojiti naslednje pojme in problematiko:}

- $\quad$ za vse obveznosti družbe, ki so nastale do vpisa delitve v register, so poleg družbe, ki ji je $\mathrm{v}$ delitvenem načrtu dodeljena obveznost, kot solidarni dolžniki odgovorne vse druge družbe, ki so udeležene pri delitvi, in sicer vsaka do višine vrednosti premoženja, ki ji je bilo dodeljeno $\mathrm{v}$ delitvenem načrtu, zmanjšane za obveznosti, ki so ji bile dodeljene v delitvenem načrtu (tj. do višine neto premoženja) (1. odst. 636. člena ZGD-1);

- upnik lahko terja 100.000 EUR od družbe A (ta je glavna dolžnica in jamči neomejeno, z vsem svojim premoženjem);

- družbe B, C, ¿ C in D pa so solidarne dolžnice (primarno, ne subsidiarno), vendar je njihova odgovornost omejena na višino neto aktive;

- $\quad$ za notranja razmerja je merodajen delitveni načrt - tudi regresno pravico je smotrno urediti v delitvenem načrtu; 
- v notranjem razmerju družbe B, C, Č in D odgovarjajo po enakih delih - na vsako pade 25.000 (1. odst. 405. člena OZ), od glavne dolžnice se lahko terja nazaj do celote. ${ }^{25}$

\section{Vaja D39}

Pri pripojitvi sta udeleženi prevzeta družba (PT) in prevzemna družba (PM). Ekonomska vrednost PT je 16.000.000 EUR, izdala pa je 10.000 delnic. Ekonomska vrednost PM je 40.000.000 EUR, izdaja pa je 20.000 delnic. Pripojitev se izvede tako, da se poveča osnovni kapital prevzemne družbe. ${ }^{26}$

\section{Naloge oz: vprašanja:}

a) Izračunajte menjalno razmerje.

b) Delniška struktura PT je naslednja: oseba A je imetnik 5.800 delnic oseba B je imetnik 1.700 delnic oseba $C$ je imetnik 500 delnic oseba D je imetnik 2.000 delnic Izračunajte število delnic PM, do katerih je upravičen posamezni delničar PT.

c) Delniška struktura PT je naslednja: oseba A je imetnik 5.798 delnic oseba B je imetnik 1.702 delnic oseba $C$ je imetnik 500 delnic oseba D je imetnik 2.000 delnic Izračunajte število delnic PM, do katerih je upravičen posamezni delničar PT in morebitni znesek denarnih doplačil.

\footnotetext{
${ }^{25}$ S. Prelič v M. Kocbek (redaktor), Veliki komentar Zakona o gospodarskih družbah, druga dopolnjena izdaja z novelami ZGD-1A in ZGD-1H, 3. knjiga, IUS SOFTWARE, GV Založba, Ljubljana, 2014, str. 602-605.

${ }^{26}$ N. Plavšak v M. Kocbek (redaktor), Veliki komentar Zakona o gospodarskih družbah, druga dopolnjena izdaja $z$ novelami ZGD-1A in ZGD-1H, 3. knjiga, IUS SOFTWARE, GV Založba, Ljubljana, 2014, str. 197-198, 211-212.
} 


\section{Vsebina / smoter naloge je usvojiti naslednje pojme in problematiko:}

- razumevanje izračuna menjalnega razmerja in morebitnih denarnih doplačil;

- izračunamo ekonomsko vrednost delnice prevzete in prevzemne družbe in ju primerjamo $(1.600 / 2000=0,8)$, kar pomeni, da je menjalno razmerje: za 0,8 delnice prevzete družbe prejmete 1 delnico prevzemne družbe; $0,8: 1$;

- $\quad$ v b) primeru A prejme 4.680 delnic, zagotovi se skupaj 8.000 novih delnic prevzemne družbe (PM ima potem skupaj 28.000 delnic);

- $\quad$ v c) primeru A prejme 4.638,4 delnice oz. 4.638 delnic in za 0,4 delnice denarnega doplačila; PM izda 7.999 novih delnic in za 2.000 EUR (namesto ene delnice) zagotovi denarna doplačila; osebi A zagotovi 800 EUR denarnih doplačil. 


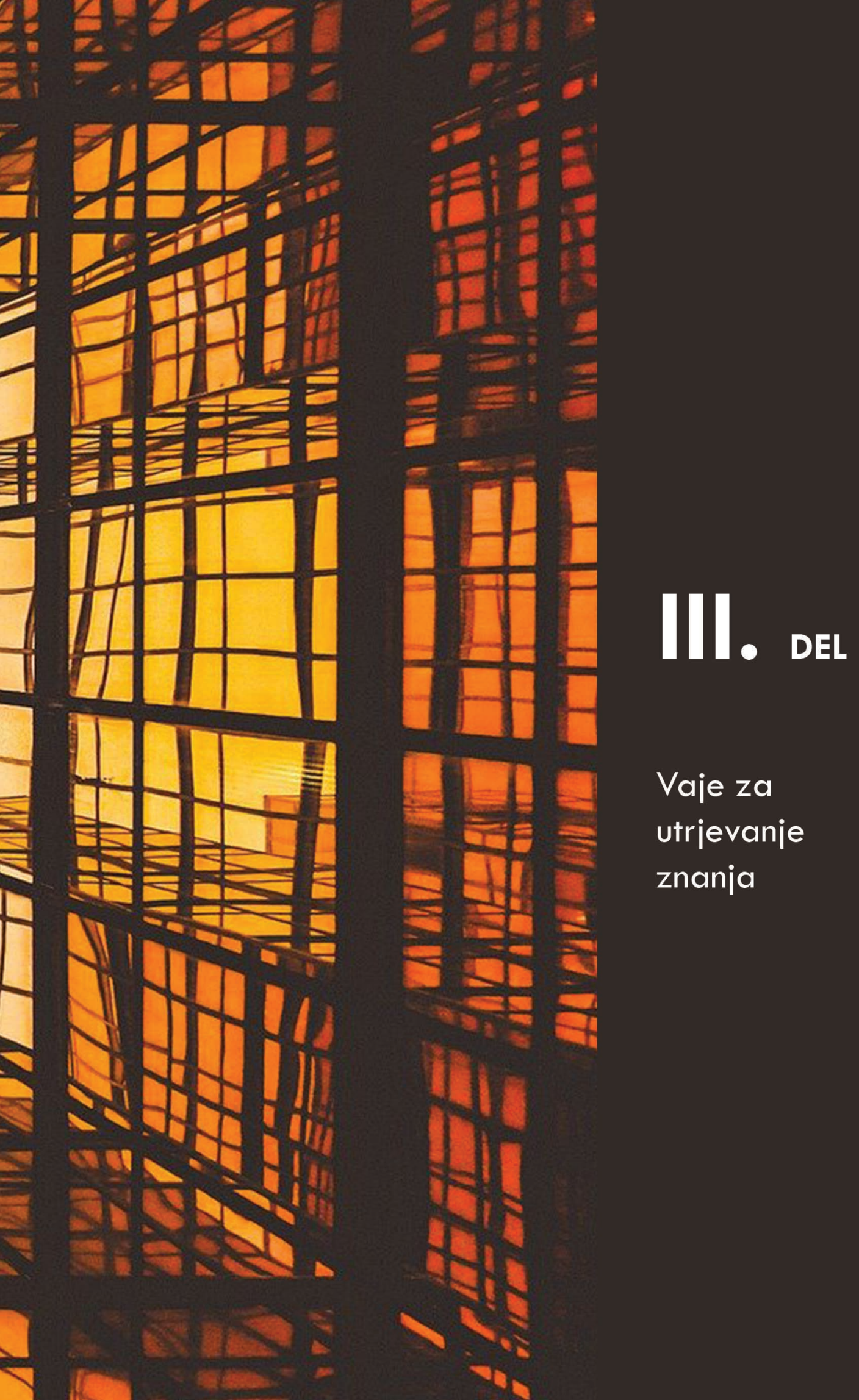




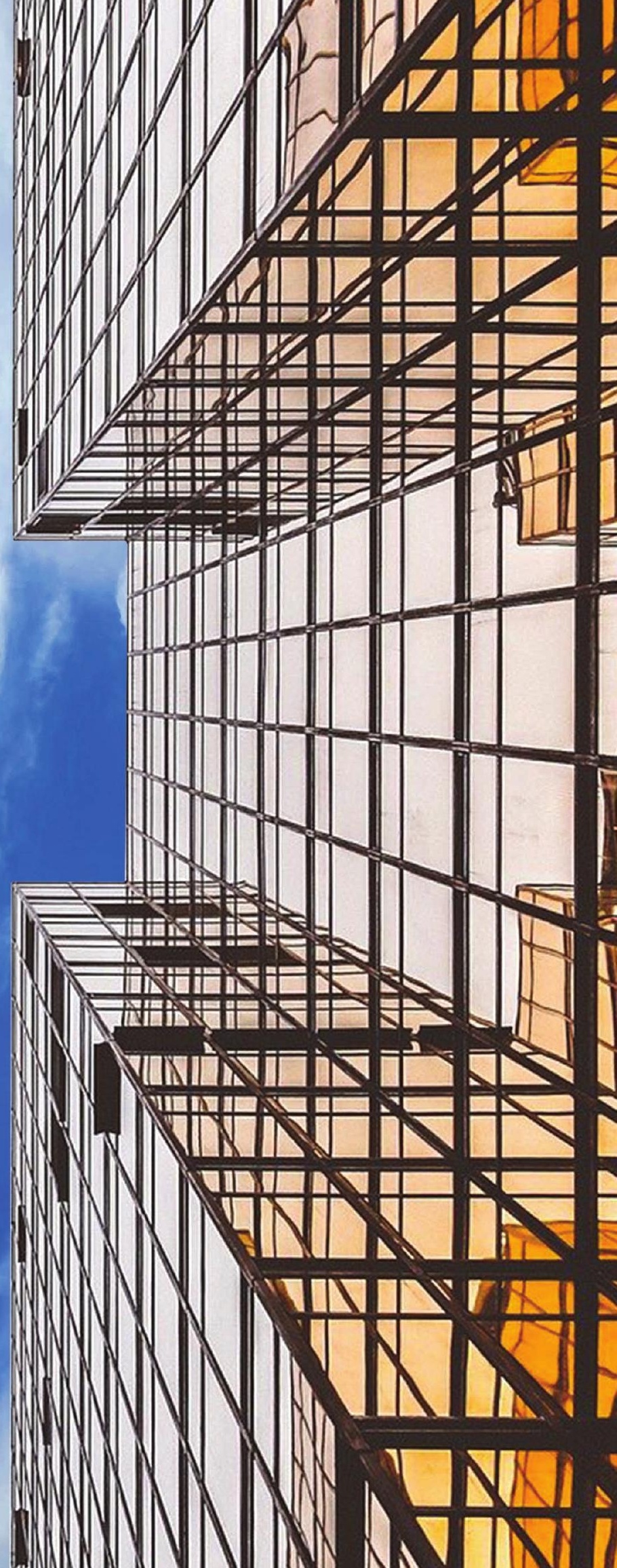




\section{SKLOP VAJ Z OZNAKO: E}

\section{Vaja E1}

Osebi AA in BB sta na začetku leta ustanovili E1 d.o.o. z 10.000 EUR osnovnega kapitala. Osebi AA in BB sta se $z$ družbeno pogodbo dogovorili, da se $\mathrm{v}$ trenutku ustanovitve vpokliče le 80 odstotkov osnovnega kapitala. Preostanek osnovnega kapitala (v obliki denarnega vložka) pa lahko poslovodstvo družbe vpokliče po potrebi (po preteku pol leta od ustanovitve družbe).

Oseba AA je zagotovila poslovni prostor kot stvarni vložek v višini 4.000 EUR in 1.000 EUR denarnega vložka, oseba BB pa je zagotovila 5.000 EUR denarnega vložka. Oseba BB je takoj ob ustanovitvi tudi vplačala denarni vložek (za vpoklican osnovni kapital) na transakcijski račun novoustanovljene družbe.

V družbi E1 d.o.o. se tekom leta zgodi naslednji poslovni dogodek:

- Glede na poslovanje družba E1 d.o.o. nujno potrebuje še preostali nevpoklicani znesek osnovnega kapitala. Tik pred koncem poslovnega leta poslovodstvo družbe vpokliče preostali znesek osnovnega kapitala v višini 2.000 EUR. Osebi AA in BB vplačata vsak 1.000 EUR denarnega vložka na transakcijski račun družbe. 
Naloga in uprašanja (z.navodili):

- Izdelajte poenostavljeno shemo bilance stanja družbe E1 d.o.o. na začetku leta.

- Katera sredstva (premoženje) in obveznosti (do virov sredstev) ima družba? Koliko?

- Kolikšna je knjigovodska vrednost kapitala družbe?

- Kolikšno je razmerje med družbenikoma v družbi?

- Če bi družbo likvidirali, kolikšen bi bil obseg sredstev (premoženja), razpoložljivih(ega) upnikom družbe?

- Izdelajte poenostavljeno shemo bilance stanja družbe E1 d.o.o. na koncu leta.

- Katera sredstva (premoženje) in obveznosti (do virov sredstev) ima družba? Koliko?

- Kolikšna je knjigovodska vrednost kapitala družbe?

- Kolikšno je razmerje med družbenikoma v družbi?

- Če bi družbo likvidirali, kolikšen bi bil obseg sredstev (premoženja), razpoložljivih(ega) upnikom družbe?

(Opomba: prikažite izračune in zapišite odgovore.)

Rešitev

Bilanca stanja (pred dogodkom vpoklica OK)

\begin{tabular}{|c|c|c|c|}
\hline \multirow{4}{*}{$\begin{array}{l}\text { Nepremičnina (posl. prostor) } \\
\text { Denarma sredstva (na TR) }\end{array}$} & SREDSTVA & $\begin{array}{c}\text { OBV. DO } \\
\text { VIROV SRED. }\end{array}$ & \multirow{4}{*}{$\begin{array}{l}\text { Vpoklican kapital } \\
\text { Osnovni kapital } \\
\text { Nevpoklican kapital (kot } \\
\text { odbitna postavka) } \\
4.000 \text { Druð̌benik. } A A \\
4.000 \text { Druð̌benik } B B\end{array}$} \\
\hline & 4.000 & 8.000 & \\
\hline & 4.000 & 10.000 & \\
\hline & & -2.000 & \\
\hline SKUPAJ SRED. >> & 8.000 & 8.000 & $<<$ SKUPAJ OBV. \\
\hline
\end{tabular}


Bilanca stanja (po dogodku vpoklica OK)

\begin{tabular}{|c|c|c|c|}
\hline \multirow{4}{*}{$\begin{array}{r}\text { Nepremičnina (posl. prostor) } \\
\text { Denarma sredstva (na TR) }\end{array}$} & SREDSTVA & OBV. DO & \multirow{4}{*}{$\begin{array}{l}\text { Vpoklican kapital } \\
\text { Osnovni kapital } \\
\text { Nevpoklican kapital (kot } \\
\text { odbitna postavka) } \\
5.000 \text { Druð̌benik } A A \\
5.000 \text { Druð̧benik } B B\end{array}$} \\
\hline & 4.000 & 10.000 & \\
\hline & 6.000 & 10.000 & \\
\hline & & 0 & \\
\hline SKUPAJ SRED. >> & 10.000 & 10.000 & << SKUPAJ OBV. \\
\hline
\end{tabular}

\section{Vaja E2}

Osebi AA in BB sta na začetku leta ustanovili družbo E2 d.o.o. s 50.000 EUR osnovnega kapitala. Obe sta zagotovili 25.000 EUR denarnega vložka in takoj ob ustanovitvi tudi vplačali denarna sredstva $\mathrm{v}$ celoti na transakcijski račun novoustanovljene družbe.

V družbi E2 d.o.o. se tekom leta zgodi naslednji poslovni dogodek:

- Obstoječa družbenika osebi AA in BB pred koncem leta skleneta povečati osnovni kapital družbe E2 d.o.o. za 100 \%. Glede na njuna poslovna deleža v osnovnem kapitalu ob ustanovitvi družbe E2 d.o.o. vplačata denarna sredstva (v ustreznem znesku) v celoti na transakcijski račun družbe E2 d.o.o.

\section{Naloga in vprašanja (z, navodili):}

- Izdelajte poenostavljeno shemo bilance stanja družbe E2 d.o.o. na začetku leta.

- Izdelajte poenostavljeno shemo bilance stanja družbe E2 d.o.o. na koncu leta.

- Katera sredstva (premoženje) in obveznosti (do virov sredstev) ima družba? Koliko?

- Kolikšna je knjigovodska vrednost kapitala družbe?

- Kolikšna je knjigovodska vrednost poslovnega deleža vsakega družbenika?

(Opomba: prikažite izračune in zapisite odgovore.) 


\section{Rešitev}

\section{Bilanca stanja}

\begin{tabular}{|c|c|c|c|}
\hline \multirow{3}{*}{ Denarma sredstva (na TR) } & SREDSTVA & OBV. DO & \multirow{3}{*}{$\begin{array}{c}\text { Osnovni kapital (vpoklican) } \\
50.000 \quad \text { Družbenik } A A \\
50.000 \quad \text { Družbenik } B B\end{array}$} \\
\hline & 100.000 & 100.000 & \\
\hline & & & \\
\hline SKUPAJ SRED. >> & 100.000 & 100.000 & << SKUPAJ OBV. \\
\hline
\end{tabular}

\section{Vaja E3}

Osebi AA in BB sta na začetku leta ustanovili E3 d.o.o. z 10.000 EUR osnovnega kapitala. Obe sta zagotovili 5.000 EUR denarnega vložka in takoj ob ustanovitvi tudi vplačali denarna sredstva $\mathrm{v}$ celoti na transakcijski račun novoustanovljene družbe.

V družbi E3 d.o.o. se tekom leta zgodita naslednja poslovna dogodka:

- Družba E3 d.o.o. na začetku leta izda 10 obveznic po 100 EUR na obveznico, ki jih uspešno proda. Izdana obveznica daje njenemu imetniku možnost menjave obveznice za poslovni delež v družbi E3 d.o.o. Prodane obveznice plača kupec družba KRIPTO d.o.o. takoj z nakazilom denarnih sredstev na transakcijski račun družbe E3 d.o.o. (Opomba: stroškov v zvezi z izdajo in prodajo obveznic ni.)

- Imetnik obveznic družba KRITPO d.o.o. pred koncem leta sprejme sklep o zamenjavi vseh kupljenih obveznic za poslovni delež v družbi E3 d.o.o. $\mathrm{V}$ trenutku menjave je tečaj obveznice 80 EUR, glede na katerega družba KRIPTO d.o.o. pridobi poslovni delež v družbi E3 d.o.o. Družba E3 d.o.o. pred koncem leta vpiše $\mathrm{v}$ register sklep o pogojnem povečanju.

\section{Naloga in uprašanja (z navodili):}

- Izdelajte poenostavljeno shemo bilance stanja družbe E3 d.o.o. na začetku leta.

- Izdelajte poenostavljeno shemo bilance stanja družbe E3 d.o.o. na koncu leta.

- Katera sredstva (premoženje) in obveznosti (do virov sredstev) ima družba? Koliko?

- Kolikšna je knjigovodska vrednost kapitala družbe? 
- Kolikšna je knjigovodska vrednost poslovnega deleža vsakega družbenika?

(Opomba: prikažite izračune in zapisite odgovore.)

\section{Rešitev}

Bilanca stanja

\begin{tabular}{|c|c|c|c|}
\hline & & & \multirow[b]{3}{*}{ Osnovni kapital (vpoklican) } \\
\hline \multirow{7}{*}{ Denarma sredstva (na TR) } & SREDSTVA & $\begin{array}{c}\text { OBV. DO } \\
\text { VIROV SRED. }\end{array}$ & \\
\hline & \multirow[t]{6}{*}{11.000} & \multirow[t]{4}{*}{10.800} & \\
\hline & & & 5.000 Družbenik. $A A(0,4545)$ \\
\hline & & & 5.000 Druそ̌benik BB $(0,4545)$ \\
\hline & & & $800 \begin{array}{l}\text { Druzbenik, CC (NOV) } \\
(0,0727)\end{array}$ \\
\hline & & 200 & $\begin{array}{l}\text { Kapitalske rezerve (vplačila } \\
\text { nad najmanjšim emisijskim } \\
\text { zneskom kapitala, pridobljeno } \\
\text { z izdajo zamenivih obveznic) }\end{array}$ \\
\hline & & 0 & $\begin{array}{l}\text { Izdane obveznice (dolžniško } \\
\text { financiranje) }\end{array}$ \\
\hline SKUPAJ SRED. >> & 11.000 & 11.000 & << SKUPAJ OBV. \\
\hline
\end{tabular}

Vaja E4

Osebi AA in BB sta na začetku leta ustanovili E4 d.o.o. z 10.000 EUR osnovnega kapitala. Obe sta zagotovili 7.000 EUR denarnega vložka in takoj ob ustanovitvi tudi vplačali denarna sredstva $\mathrm{v}$ celoti na transakcijski račun novoustanovljene družbe.

V družbi E4 d.o.o. se tekom leta zgodi naslednji poslovni dogodek:

- Družba E4 d.o.o. je opravila storitev pravnega svetovanja (na področju korporacijskega prava) v vrednosti 5.000 EUR za naročnika fizično osebo CC. Oseba CC je opravljeno storitev poplačala takoj z nakazilom na transakcijski račun družbe E4 d.o.o. Storitev pravnega svetovanja je bila t. i. intelektualna storitev, pri opravljanju katere družba E4 d.o.o. ni uporabila ali potrošila nobenih svojih sredstev. (Opomba: davščin - npr. davka na dodano vrednost v zvezi s prodajo storitve ni.)

V družbi E4 d.o.o. se po koncu poslovnega leta zgodi naslednji poslovni dogodek: 
- Družbenika sta se po koncu poslovnega leta dogovorila in odločila, da se naj poveča osnovni kapital družbe E4 d.o.o. v višini 5.000 EUR brez njunih dodanih vložkov v družbo. Družbenika sta se odločila, da se naj se za povečanje osnovnega kapitala uporabi del nerazporejenega dobička v višini 3.000 EUR in razpoložljive kapitalske rezerve $\mathrm{v}$ višini 2.000 EUR. Hkrati sta se tudi dogovorila, da naj bo povečanje osnovnega kapitala glede na njuna poslovna deleža v osnovnem kapitalu ob ustanovitvi družbe E4 d.o.o. Povečanje osnovnega kapitala družbe E4 d.o.o. je vpisano v register.

\section{Naloga in vprašanja (z.navodili):}

- Izdelajte poenostavljeno shemo bilance stanja družbe E4 d.o.o. na začetku leta.

- Izdelajte poenostavljeno shemo bilance stanja družbe E4 d.o.o. na koncu leta (pred dogodkom dokapitalizacije).

- Izdelajte poenostavljeno shemo bilance stanja družbe E4 d.o.o. po koncu leta (torej po dogodku dokapitalizacije). (Opomba: davka na dobiček - natančneje: davka od dohodka pravnih oseb - ni.)

- Katera sredstva (premoženje) in obveznosti (do virov sredstev) ima družba? Koliko?

- Kolikšna je knjigovodska vrednost kapitala družbe?

- Kolikšna je knjigovodska vrednost poslovnega deleža vsakega družbenika?

(Opomba: prikažite izračune in qapišite odgovore.)

\section{Rešitev}

Izkaz poslovnega izida

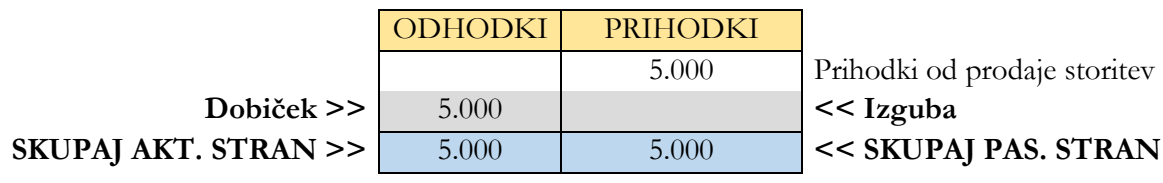


Bilanca stanja (po dogodku nominalnega povečanja OK)

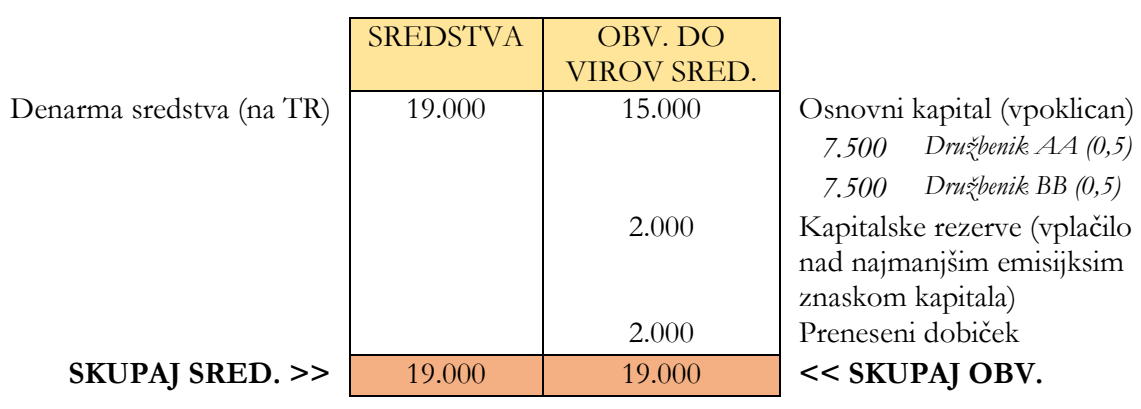




\section{SKLOP VAJ Z OZNAKO: F}

\section{Vaja F1}

Oseba AA je na začetku leta ustanovila družbo F1 d.o.o. z 10.000 EUR osnovnega kapitala. Oseba AA je zagotovila kopirni stroj kot stvarni vložek v višini 4.000 EUR in 6.000 EUR denarnega vložka. Ob ustanovitvi družbe se je oseba AA prav tako odločila za vplačilo tudi 20-odstotne premije na ustanovitveni vložek. Oseba AA je takoj ob ustanovitvi tudi vplačala vsa denarna sredstva v celoti na transakcijski račun novoustanovljene družbe.

V družbi F1 d.o.o. se tekom leta zgodijo naslednji poslovni dogodki:

- Družba F1 d.o.o. je zaradi načrtovanega opravljanja storitev pravnega svetovanja potrebovala več računalniških in drugih pripomočkov (računalnik, tiskalnik, omrežno opremo itd.). Takoj na začetku leta je družba pripomočke v vrednosti 6.000 EUR kupila pri dobavitelju družbi PP d.o.o., kateri je poplačala takoj z nakazilom denarnih sredstev s svojega transakcijskega računa. (Opomba: davščin - npr. davka na dodano vrednost - v zvezi z nakupom pripomočkov ni.)

- Družba F1 d.o.o. je pripomočke uporabljala celo leto, zaradi česar je obračunala t. i. amortizacijo zanje v vrednosti 5.000 EUR. (Opomba: družba uporablja 
metodo enakomernega časovnega amortiziranja. Letna amortizacijska stopnja za računalniške pripomočke je $50 \%$.)

- Družba F1 d.o.o. je takoj po pridobitvi pripomočke zavarovala pri zavarovalnici ZAVARUJ d.d. za primer nezmožnosti uporabe teh zaradi kakršnekoli nezgode, in sicer v njihovi polni vrednosti. Zavarovalna premija, ki jo je družba plačala takoj s transakcijskega računa, je 1.000 EUR.

- Poslovodstvo družbe F1 d.o.o. je ocenilo, da potrebuje dodatna denarna sredstva za svoje poslovanje. Družba je zato takoj po ustanovitvi najela 5.000 EUR posojila pri (nepovezani) družbi POSOJA d.o.o. Posojilodajalec tudi nakaže posojilo družbi na njen transakcijski račun. (Opomba: stroškov najema posojila ni.)

- Družba F1 d.o.o. pred koncem leta prejme obračun obresti iz naslova najetega posojila v skupni vrednosti 1.000 EUR. Obresti je nakazala na transakcijski račun družbe POSOJA d.o.o. (Opomba: stroškov in davščin v zvezi z nakazilom obresti ni.)

- Družba F1 d.o.o. je opravila storitev pravnega svetovanja (na področju korporacijskega prava in davčnega prava) v vrednosti 15.000 EUR za naročnika fizično osebo BB. Oseba BB je opravljeno storitev poplačala takoj z nakazilom na transakcijski račun družbe F1 d.o.o. Storitev pravnega svetovanja je bila t. i. intelektualna storitev. (Opomba: davščin - npr. davka na dodano vrednost - v zvezi s prodajo storitve ni.)

- Družba F1 d.o.o. je obračunala delo, ki ga je opravil pri njej zaposlena oseba CC v času izvajanja storitve. Skupna vrednost obračunanega dela je 10.000 EUR. Družba F1 d.o.o. je v zvezi z obračunanim delom izvedla nakazili s svojega transakcijskega računa osebi CC in v državni proračun.

\section{Naloga in vprašanja (z. navodili):}

- Izdelajte poenostavljeno shemo bilance stanja družbe F1 d.o.o. na začetku leta.

- Izdelajte poenostavljeno shemo izkaza poslovnega izida družbe F1 d.o.o. za poslovno leto. (Opomba: davka na dobiček - natančneje: davka od dohodka pravnih oseb - ni.)

- Če ima, katere prihodke in/ali odhodke ima družba? Koliko?

- Kateri je poslovni izid? Kolikšen?

- Izdelajte poenostavljeno shemo bilance stanja družbe F1 d.o.o. na koncu leta.

- Katera sredstva (premoženje) in obveznosti (do virov sredstev) ima družba? Koliko? 
- Kolikšna je knjigovodska vrednost kapitala družbe?

- Če bi družbo likvidirali, kolikšen bi bil obseg sredstev (premoženja), razpoložljivih(ega) upnikom družbe?

- Kolikšna je knjigovodska, likvidacijska in tržna vrednost poslovnega deleža družbenika v družbi?

(Opomba: prikažite irračune in zapisite odgovore.)

\section{Rešitev}

Izkaz poslovnega izida

\begin{tabular}{r|c|c|c}
\cline { 2 - 3 } & ODHODKI & PRIHODKI & \multirow{2}{*}{ Prihodki od prodaje storitev } \\
\cline { 2 - 3 } Stroški amortizacije & 5.000 & 15.000 & \\
Strošek zav. premije & 1.000 & & \\
Stroški dela & 10.000 & & \\
Odhodki (str. finan.) & 1.000 & & \\
Dobiček $>>$ & & 2.000 & $<$ Izguba \\
\cline { 3 - 3 } SKUPAJ AKT. STRAN $>>$ SKUPAJ PAS. STRAN & 17.000 & 17.000 & $<$
\end{tabular}

Bilanca stanja

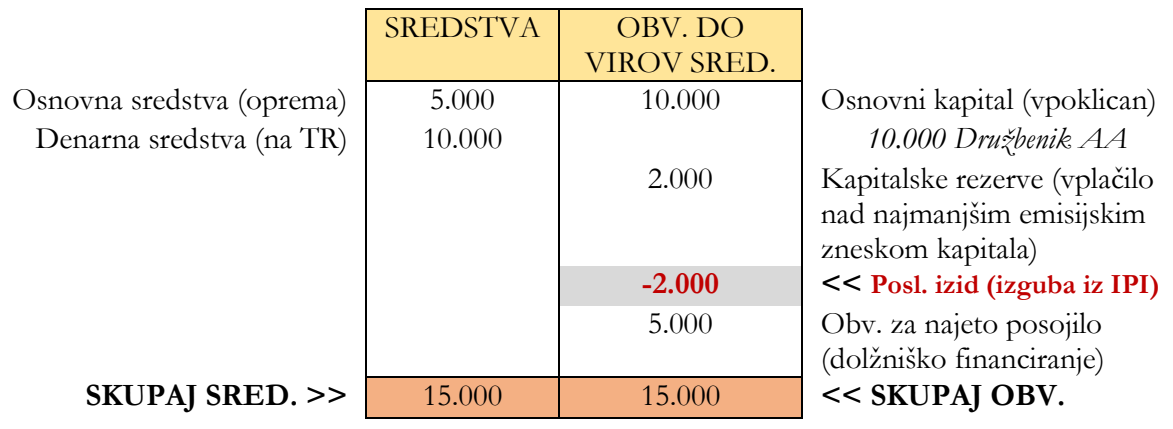


Vaja F2

Osebi AA in BB sta na začetku leta ustanovili družbo F2 d.o.o. z 10.000 EUR osnovnega kapitala. Oseba AA ima $40 \%$ poslovni delež v tej družbi, oseba BB pa $60 \%$ poslovni delež v tej družbi. Oseba AA je zagotovila poslovni prostor kot stvarni vložek v višini 4.000 EUR, oseba BB pa je zagotovila 6.000 EUR denarnega vložka. Oseba BB je takoj ob ustanovitvi tudi vplačala celotni denarni vložek na transakcijski račun novoustanovljene družbe.

V družbi F2 d.o.o. se tekom leta zgodijo naslednji poslovni dogodki:

- Družba F2 d.o.o. je zaradi načrtovanega opravljanja storitev poslovnega svetovanja potrebovala več računalniških in drugih pripomočkov (računalnik, tiskalnik, kopirni stroj itd.). Takoj na začetku leta je družba pripomočke $\mathrm{v}$ vrednosti 6.000 EUR kupila pri dobavitelju družbi PP d.o.o., kateri je poplačala takoj z nakazilom denarnih sredstev s svojega transakcijskega računa. (Opomba: davščin - npr. davka na dodano vrednost - v zvezi z nakupom pripomočkov ni.)

- Družba F2 d.o.o. je pripomočke uporabljala celo leto, zaradi česar je obračunala t. i. amortizacijo zanje v vrednosti 3.000 EUR. (Opomba: družba uporablja metodo enakomernega časovnega amortiziranja. Letna amortizacijska stopnja za računalniške pripomočke je $50 \%$.)

- Družba F2 d.o.o. je poslovni prostor uporabljala celo leto, zaradi česar je obračunala t. i. amortizacijo zanj v vrednosti 1.000 EUR. (Opomba: družba uporablja metodo enakomernega časovnega amortiziranja. Letna amortizacijska stopnja za poslovni prostor je $25 \%$.)

- Družba F2 d.o.o. je na začetku leta izdala obveznice v skupni vrednosti 10.000 EUR, ki jih uspešno prodala. Prodane obveznice je plačal kupec banka BANKA d. d. takoj z nakazilom denarnih sredstev na transakcijski račun družbe F2 d.o.o. (Opomba: stroškov v zvezi z izdajo in prodajo obveznic ni.)

- Družba F2 d.o.o. pred koncem leta obračuna (kuponske) obresti iz naslova izdane obveznice v skupni vrednosti 2.000 EUR. Obresti je nakazala na transakcijski račun banke BANKA d.d. (Opomba: stroškov in davščin v zvezi z nakazilom obresti ni.)

- Poslovodstvo družbe F2 d.o.o. je takoj po ustanovitvi odobrilo posojilo v višini 5.000 EUR (nepovezani) družbi KARTA d.o.o. Družba kot posojilodajalec je 
tudi nakazala posojilo družbi posojilojemalki na njen transakcijski račun. (Opomba: stroškov v zvezi z odobritvijo in nakazilom posojila ni.)

- Družba F2 d.o.o. pred koncem leta obračuna obresti iz naslova danega posojila v skupni vrednosti 1.000 EUR. Obresti je prejela nakazane na svoj transakcijski račun s strani posojilojemalke družbe KARTA d.o.o. (Opomba: stroškov in davščin v zvezi s prejemom nakazila obresti ni.)

- Družba F2 d.o.o. je za izvedbo storitve dajanja posojila naročila storitev bonitetnega pregleda možnega posojilojemalca pri izkušenem analitiku v vrednosti 1.000 EUR. Družba F2 d.o.o. je kupljeno storitev izkušenemu analitiku plačala takoj z nakazilom s svojega transakcijskega računa. (Opomba: davščin - npr. davka na dodano vrednost - v zvezi z nakupom storitve ni.)

- Družba F2 d.o.o. je opravila storitev poslovnega svetovanja v vrednosti 9.000 EUR za naročnika fizično osebo CC. Oseba CC je opravljeno storitev poplačala takoj z nakazilom na transakcijski račun družbe F2 d.o.o. Storitev pravnega svetovanja je bila t. i. intelektualna storitev. (Opomba: davščin - npr. davka na dodano vrednost - v zvezi s prodajo storitve ni.)

- Družba F2 d.o.o. je obračunala delo, ki ga je opravil pri njej zaposlena oseba DD v času izvajanja storitve. Skupna vrednost obračunanega dela je 1.000 EUR. Družba F2 d.o.o. je v zvezi z obračunanim delom izvedla nakazili s svojega transakcijskega računa osebi DD in v državni proračun.

\section{Naloga in vprašanja (z. navodili):}

- Izdelajte poenostavljeno shemo bilance stanja družbe F2 d.o.o. na začetku leta.

- Izdelajte poenostavljeno shemo izkaza poslovnega izida družbe F2 d.o.o. za poslovno leto. (Opomba: davka na dobiček - natančneje: davka od dohodka pravnih oseb - ni.)

- Če ima, katere prihodke in/ali odhodke ima družba? Koliko?

- Kateri je poslovni izid? Kolikšen?

- Izdelajte poenostavljeno shemo bilance stanja družbe F2 d.o.o. na koncu leta.

- Katera sredstva (premoženje) in obveznosti (do virov sredstev) ima družba? Koliko?

- Kolikšna je knjigovodska vrednost kapitala družbe?

- Če bi družbo likvidirali, kolikšen bi bil obseg sredstev (premoženja), razpoložljivih(ega) upnikom družbe? 
- Kolikšna je knjigovodska, likvidacijska in tržna vrednost poslovnega deleža vsakega družbenika v družbi?

(Opomba: prikažite izračune in zapišite odgovore.)

\section{Rešitev}

Izkaz poslovnega izida

\begin{tabular}{r|c|c|l}
\cline { 2 - 3 } & ODHODKI & PRIHODKI & \multirow{2}{*}{ Prihodki od prodaje storitve } \\
\cline { 2 - 3 } Stroški amortizacije & 4.000 & 9.000 & \\
Stroški kupljenih storitev & 1.000 & 1.000 & $\begin{array}{l}\text { Finančni prihodki (od } \\
\text { prejetih obresti) }\end{array}$ \\
Stroški dela & 1.000 & & \\
Odhodki (str. finan.) & 2.000 & & \\
Dobiček $>>$ & 2.000 & & $<$ Izguba \\
SKUPAJ AKT. STRAN $>>$ & 10.000 & 10.000 & $<$ SKUPAJ PAS. STRAN
\end{tabular}

Bilanca stanja

\begin{tabular}{|c|c|c|c|}
\hline \multirow{3}{*}{$\begin{array}{r}\text { Osnovna sredstva (oprema) } \\
\text { Finančna naložba (dano } \\
\text { posojilo) }\end{array}$} & SREDSTVA & $\begin{array}{c}\text { OBV. DO } \\
\text { VIROV SRED. }\end{array}$ & \multirow[b]{2}{*}{ Osnovni kapital (vpoklican) } \\
\hline & 6.000 & 10.000 & \\
\hline & 5.000 & & 4.000 Družbenik $A A$ \\
\hline Denarna sredstva (na TR) & 11.000 & & 6.000 Dru气̌benik BB \\
\hline & & 2.000 & $\begin{array}{l}<<\text { Posl. izid (dobiček iz } \\
\text { IPI) }\end{array}$ \\
\hline & & 10.000 & $\begin{array}{l}\text { Izdane delnice (dolžniško } \\
\text { financiranje) }\end{array}$ \\
\hline SKUPAJ SRED. >> & 22.000 & 22.000 & << SKUPAJ OBV. \\
\hline
\end{tabular}

\section{Vaja F3}

Osebe AA, BB in CC so na začetku leta ustanovile družbo F3 d.o.o. z 20.000 EUR osnovnega kapitala. Oseba AA ima 50 \% poslovni delež v tej družbi, oseba BB 30 $\%$ in oseba CC $20 \%$ poslovni delež v tej družbi. Osebe AA, BB in CC so zagotovile 10.000 EUR, 6.000 EUR in 4.000 EUR denarnega vložka. Osebe AA, BB in CC so takoj ob ustanovitvi tudi vplačale celotni denarni vložek na transakcijski račun novoustanovljene družbe. 
V družbi F3 d.o.o. se tekom leta zgodijo naslednji poslovni dogodki:

- Družba F3 d.o.o. je zaradi načrtovanega opravljanja storitev pravnega svetovanja potrebovala več računalniških in drugih pripomočkov (računalnik, tiskalnik, kopirni stroj itd.). Takoj na začetku leta je družba pripomočke $\mathrm{v}$ vrednosti 8.000 EUR kupila pri dobavitelju družbi RR d.o.o., kateri je poplačala takoj z nakazilom denarnih sredstev s svojega transakcijskega računa. (Opomba: davščin - npr. davka na dodano vrednost $-\mathrm{v}$ zvezi z nakupom pripomočkov ni.)

- Družba F3 d.o.o. je pripomočke uporabljala celo leto, zaradi česar je obračunala t. i. amortizacijo zanje v vrednosti 4.000 EUR. (Opomba: družba uporablja metodo enakomernega časovnega amortiziranja. Letna amortizacijska stopnja za računalniške pripomočke je $50 \%$.)

- Družba F3 d.o.o. na začetku leta kupi delnice druge družbe ZZ d.d. v skupni vrednosti 8.000 EUR. Kupljene delnice plača takoj z nakazilom denarnih sredstev s transakcijskega računa družbe prodajalcu delnic. (Opomba: stroškov $\mathrm{v}$ zvezi s prenosom delnic ni.)

- Družba F3 d.o.o. pred koncem leta prejme dividende od družbe ZZ d.d. v skupni vrednosti 1.000 EUR. Nakazilo je bilo izvršeno na transakcijski račun družbe F3 d.o.o. (Opomba: davščin v zvezi z nakazilom dividend oz. potrebe po akontaciji davščin ni.)

- Družba F3 d.o.o. je opravila storitev pravnega svetovanja (na področju korporacijskega prava in davčnega prava) v vrednosti 18.000 EUR za naročnika fizično osebo DD. Oseba DD je opravljeno storitev poplačala takoj z nakazilom na transakcijski račun družbe F3 d.o.o. Storitev pravnega svetovanja je bila t. i. intelektualna storitev. (Opomba: davščin - npr. davka na dodano vrednost - v zvezi s prodajo storitve ni.)

- Družba F3 d.o.o. je obračunala delo, ki ga je opravila pri njej zaposlena oseba EE v času izvajanja storitve. Skupna vrednost obračunanega dela je 8.000 EUR. Družba F3 d.o.o. je v zvezi z obračunanim delom izvedla nakazili s svojega transakcijskega računa osebi EE in $\mathrm{v}$ državni proračun.

- Družba F3 d.o.o. je za izvedbo storitve pravnega svetovanja naročila storitev pravnega pregleda pri izkušenem pravniku osebi FF v vrednosti 2.000 EUR. Družba F3 d.o.o. je kupljeno storitev izkušenemu pravniku osebi FF plačala takoj z nakazilom s svojega transakcijskega računa. (Opomba: davščin - npr. davka na dodano vrednost - v zvezi z nakupom storitve ni.) 
Naloga in vprašanja (žnavodili):

- Izdelajte poenostavljeno shemo bilance stanja družbe F3 d.o.o. na začetku leta.

- Izdelajte poenostavljeno shemo izkaza poslovnega izida družbe F3 d.o.o. za poslovno leto. (Opomba: davka na dobiček - natančneje: davka od dohodka pravnih oseb - ni.)

- Če ima, katere prihodke in/ali odhodke ima družba? Koliko?

- Kateri je poslovni izid? Kolikšen?

- Izdelajte poenostavljeno shemo bilance stanja družbe F3 d.o.o. na koncu leta.

- Katera sredstva (premoženje) in obveznosti (do virov sredstev) ima družba? Koliko?

- Kolikšna je knjigovodska vrednost kapitala družbe?

- Če bi družbo likvidirali, kolikšen bi bil obseg sredstev (premoženja), razpoložljivih(ega) upnikom družbe?

- Kolikšna je knjigovodska, likvidacijska in tržna vrednost poslovnega deleža vsakega družbenika v družbi?

(Opomba: prikažite iæračune in zapišite odgovore.)

Rešitev

Izkaz poslovnega izida

\begin{tabular}{|c|c|c|c|}
\hline & ODHODKI & PRIHODKI & \\
\hline Stroški amortizacije & 4.000 & 18.000 & Prihodki od prodaje storitev \\
\hline Stroški kupljenih storitev & 2.000 & 1.000 & $\begin{array}{l}\text { Finančni prihodki (od } \\
\text { prejetih dividend) }\end{array}$ \\
\hline Stroški dela & 8.000 & & \\
\hline Dobiček $>>$ & 5.000 & & $<<$ Izguba \\
\hline SKUPAJ AKT. STRAN >> & 19.000 & 19.000 & $<<$ SKUPAJ PAS. STRAN \\
\hline
\end{tabular}

Bilanca stanja

\begin{tabular}{|c|c|c|c|}
\hline \multirow{4}{*}{$\begin{array}{r}\text { Osnovna sredstva (oprema) } \\
\text { Finančna naložba (kupljene } \\
\text { delnice) }\end{array}$} & SREDSTVA & OBV.DO & \multirow{2}{*}{ Osnovni kapital (vpoklican) } \\
\hline & & $\frac{\text { VIROV SRED. }}{20000}$ & \\
\hline & 8.000 & \multirow{4}{*}{20.000} & 10.000 Druğbenik $A A$ \\
\hline & & & \\
\hline \multirow[t]{3}{*}{ Denarna sredstva (na TR) } & \multirow[t]{3}{*}{13.000} & & 6.000 Družbenik BB \\
\hline & & & 4.000 Druそ̌benik. CC \\
\hline & & 5.000 & \multirow{2}{*}{$\begin{array}{l}<<\text { Posl. izid (dobiček iz } \\
\text { IPI) } \\
<<\text { SKUPAJ OBV. }\end{array}$} \\
\hline SKUPAJ SRED. >> & 25.000 & 25.000 & \\
\hline
\end{tabular}




\section{SKLOP VAJ Z OZNAKO: G}

\section{Vaja G1}

Osebi AA in BB sta na začetku leta ustanovili družbo G1 d.o.o. z 10.000 EUR osnovnega kapitala. Oseba AA ima $25 \%$ poslovni delež v tej družbi, oseba BB pa $75 \%$ poslovni delež v tej družbi. Osebi $\mathrm{AA}$ in $\mathrm{BB}$ sta zagotovili celoten denarni vložek. Takoj ob ustanovitvi sta vplačali celotni denarni vložek na transakcijski račun novoustanovljene družbe.

V družbi G1 d.o.o. se tekom leta zgodi več poslovnih dogodkov. Družba ima na koncu poslovnega leta poslovni izid enak nič (torej nima niti dobička niti izgube).

Po koncu poslovnega leta vstopi v družbo nov družbenik oseba CC, ki ima nato v družbi G1 d.o.o. 60 \% delež. Družbeniki AA, BB in CC so se dogovorili, da je oseba CC vstopila v družbo z dokapitalizacijo družbe G1 d.o.o. Oseba CC vplača denarna sredstva (v ustreznem znesku) v celoti na transakcijski račun družbe G1 d.o.o.

Naloga in vprašanja (z navodili):

- Izdelajte poenostavljeno shemo bilance stanja družbe G1 d.o.o. na koncu leta pred dogodkom dokapitalizacije.

- Kolikšno je razmerje med družbenikoma v družbi? 
- Izdelajte poenostavljeno shemo bilance stanja družbe G1 d.o.o. na koncu leta po dogodku dokapitalizacije.

- Kolikšen znesek mora plačati oseba CC pri dogodku dokapitalizacije? Komu?

- Kolikšno je razmerje med družbeniki v družbi?

- Katera sredstva (premoženje) in obveznosti (do virov sredstev) ima družba? Koliko?

- Kolikšna je knjigovodska vrednost kapitala družbe?

- Kolikšna je knjigovodska vrednost poslovnega deleža vsakega družbenika v družbi?

(Opomba: priką̧ite izračune in zapisite odgovore.)

\section{Rešitev}

\section{Bilanca stanja (PO DOKAPITALIZACIJI)}

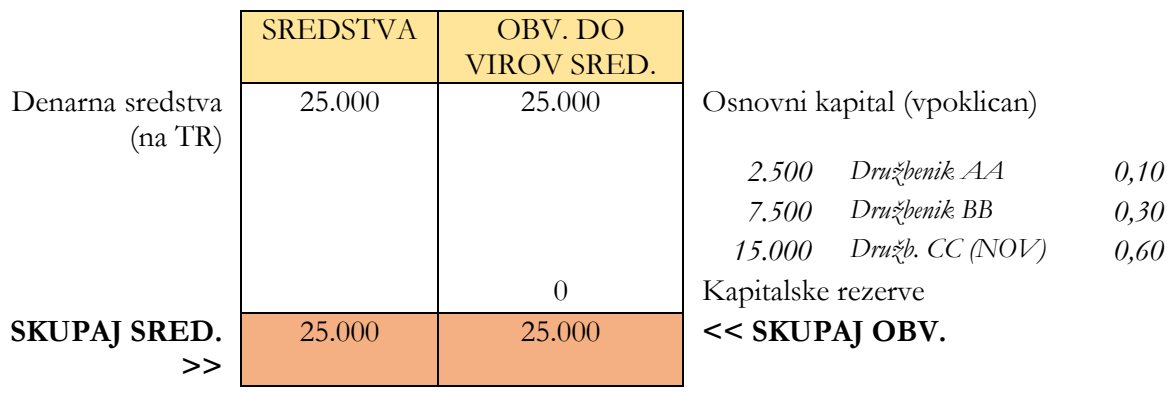

\section{Vaja G2}

Osebe AA, BB in CC so na začetku leta ustanovile družbo G2 d.o.o. s 30.000 EUR osnovnega kapitala. Oseba AA ima $10 \%$ poslovni delež v tej družbi, oseba BB 40 $\%$ in oseba CC $50 \%$ poslovni delež v tej družbi. Osebe AA, BB in CC so zagotovile 3.000 EUR, 12.000 EUR in 15.000 EUR denarnega vložka. Osebe AA, BB in CC so takoj ob ustanovitvi tudi vplačale celotni denarni vložek na transakcijski račun novoustanovljene družbe.

V družbi G2 d.o.o. se tekom leta zgodi več poslovnih dogodkov. Družba ima na koncu poslovnega leta poslovni izid enak nič (torej nima niti dobička niti izgube). 
Po koncu poslovnega leta vstopi v družbo nov družbenik oseba DD, ki ima nato v družbi G2 d.o.o. 25 \% delež. Družbeniki AA, BB, CC in DD so se dogovorili, da je oseba DD vstopila v družbo z dokapitalizacijo družbe G2 d.o.o. Oseba DD vplača denarna sredstva (v ustreznem znesku) v celoti na transakcijski račun družbe G2 d.o.o.

\section{Naloga in vprašanja (z, navodili):}

- Izdelajte poenostavljeno shemo bilance stanja družbe G2 d.o.o. na koncu leta pred dogodkom dokapitalizacije.

- Kolikšno je razmerje med družbeniki v družbi?

- Izdelajte poenostavljeno shemo bilance stanja družbe G2 d.o.o. na koncu leta po dogodku dokapitalizacije.

- Kolikšen znesek mora plačati oseba DD pri dogodku dokapitalizacije? Komu?

- Kolikšno je razmerje med družbeniki v družbi?

- Katera sredstva (premoženje) in obveznosti (do virov sredstev) ima družba? Koliko?

- Kolikšna je knjigovodska vrednost kapitala družbe?

- Kolikšna je knjigovodska vrednost poslovnega deleža vsakega družbenika v družbi?

(Opomba: prikažite iæračune in zapisite odgovore.)

\section{Rešitev}

\section{Bilanca stanja (PO DOKAPITALIZACIJI)}

\begin{tabular}{|c|c|c|c|c|}
\hline \multirow{7}{*}{$\begin{array}{r}\text { Denarna sredstva } \\
\text { (na TR) }\end{array}$} & SREDSTVA & $\begin{array}{c}\text { OBV. DO } \\
\text { VIROV SRED. }\end{array}$ & \multirow{2}{*}{\multicolumn{2}{|c|}{ Osnovni kapital (vpoklican) }} \\
\hline & \multirow[t]{6}{*}{40.000} & \multirow[t]{5}{*}{40.000} & & \\
\hline & & & 3.000 Družbenik $A A$ & 0,075 \\
\hline & & & 12.000 Družebnik BB & 0,300 \\
\hline & & & 15.000 Družb. CC & 0,375 \\
\hline & & & 10.000 Družb. DD (NOV) & 0,250 \\
\hline & & 0 & Kapitalske rezerve & \\
\hline SKUPAJ SRED. >> & 40.000 & 40.000 & $<<$ SKUPAJ OBV. & \\
\hline
\end{tabular}




\section{Vaja G3}

Osebi AA in BB sta na začetku leta ustanovili družbo G3 d.o.o. s 15.000 EUR osnovnega kapitala. Oseba AA ima $40 \%$ poslovni delež v tej družbi, oseba BB pa $60 \%$ poslovni delež v tej družbi. Osebi AA in BB sta zagotovili celoten denarni vložek. Takoj ob ustanovitvi sta vplačali celotni denarni vložek na transakcijski račun novoustanovljene družbe.

V družbi G3 d.o.o. se tekom leta zgodi več poslovnih dogodkov. Družba ima na koncu poslovnega leta poslovni izid enak nič (torej nima niti dobička niti izgube).

Po koncu poslovnega leta vstopi v družbo nov družbenik oseba CC, ki ima nato v družbi G3 d.o.o. enak poslovni delež kot oseba BB (tj. po obsegu sta njuna deleža enaka). Družbeniki AA, BB in CC so se dogovorili, da je oseba CC vstopila v družbo z dokapitalizacijo družbe G3 d.o.o. Oseba CC vplača denarna sredstva (v ustreznem znesku) v celoti na transakcijski račun družbe G3 d.o.o.

\section{Naloga in vprašanja (z.navodili):}

- Izdelajte poenostavljeno shemo bilance stanja družbe G3 d.o.o. na koncu leta pred dogodkom dokapitalizacije.

- Kolikšno je razmerje med družbenikoma v družbi?

- Izdelajte poenostavljeno shemo bilance stanja družbe G3 d.o.o. na koncu leta po dogodku dokapitalizacije.

- Kolikšen znesek mora plačati oseba CC pri dogodku dokapitalizacije? Komu?

- Kolikšno je razmerje med družbeniki v družbi?

- Katera sredstva (premoženje) in obveznosti (do virov sredstev) ima družba? Koliko?

- Kolikšna je knjigovodska vrednost kapitala družbe?

- Kolikšna je knjigovodska vrednost poslovnega deleža vsakega družbenika $\mathrm{v}$ družbi?

(Opomba: prikažite iæračune in zapišite odgovore.) 


\section{Rešitev}

Bilanca stanja (PO DOKAPITALIZACIJI)

\begin{tabular}{|c|c|c|c|c|c|}
\hline \multirow{4}{*}{$\begin{array}{r}\text { Denarna sredstva } \\
\text { (na TR) }\end{array}$} & SREDSTVA & $\begin{array}{c}\text { OBV. DO } \\
\text { VIROV SRED. }\end{array}$ & \multicolumn{2}{|c|}{ Osnovni kapital (vpoklican) } & \\
\hline & \multirow[t]{3}{*}{24.000} & \multirow[t]{3}{*}{24.000} & \multirow{4}{*}{$\begin{array}{l}\text { 6.000 Družbenik. } A A \\
\text { 9.000 Družebnik BB } \\
\text { 9.000 Družb. CC } \\
\text { (NOV) } \\
\text { Kapitalske rezerve } \\
\text { << SKUPAJ OB }\end{array}$} & \multirow{3}{*}{$\begin{array}{l}0,2500 \\
0,3750 \\
0,3750\end{array}$} & 6.000 \\
\hline & & & & & 9.000 \\
\hline & & & & & 9.000 \\
\hline SKUPAJ SRED. & 24.000 & 24.000 & & & \\
\hline
\end{tabular}

\section{Vaja G4}

Osebe AA, BB in CC so na začetku leta ustanovile družbo G4 d.o.o. s 50.000 EUR osnovnega kapitala. Oseba AA ima $20 \%$ poslovni delež v tej družbi, oseba BB 30 $\%$ in oseba CC $50 \%$ poslovni delež v tej družbi. Osebe AA, BB in CC so zagotovile 10.000 EUR, 15.000 EUR in 25.000 EUR denarnega vložka. Osebe AA, BB in CC so takoj ob ustanovitvi tudi vplačale celotni denarni vložek na transakcijski račun novoustanovljene družbe.

V družbi G4 d.o.o. se tekom leta zgodi več poslovnih dogodkov. Družba ima na koncu poslovnega leta poslovni izid enak nič (torej nima niti dobička niti izgube).

Po koncu poslovnega leta vstopi v družbo nov družbenik oseba DD, ki ima nato v družbi G4 d.o.o. enak poslovni delež kot oseba CC (tj. po obsegu sta njuna deleža enaka). Družbeniki AA, BB, CC in DD so se dogovorili, da je oseba DD vstopila v družbo z dokapitalizacijo družbe G4 d.o.o. Oseba DD vplača denarna sredstva (v ustreznem znesku) v celoti na transakcijski račun družbe G4 d.o.o.

\section{Naloga in vprašanja (z.navodili):}

- Izdelajte poenostavljeno shemo bilance stanja družbe G4 d.o.o. na koncu leta pred dogodkom dokapitalizacije.

- Kolikšno je razmerje med družbenikoma v družbi? 
- Izdelajte poenostavljeno shemo bilance stanja družbe G4 d.o.o. na koncu leta po dogodku dokapitalizacije.

- Kolikšen znesek mora plačati oseba DD pri dogodku dokapitalizacije? Komu?

- Kolikšno je razmerje med družbeniki v družbi?

- Katera sredstva (premoženje) in obveznosti (do virov sredstev) ima družba? Koliko?

- Kolikšna je knjigovodska vrednost kapitala družbe?

- Kolikšna je knjigovodska vrednost poslovnega deleža vsakega družbenika v družbi?

(Opomba: prikažite iæračune in zapišite odgovore.)

\section{Rešitev}

Bilanca stanja (PO DOKAPITALIZACIJI)

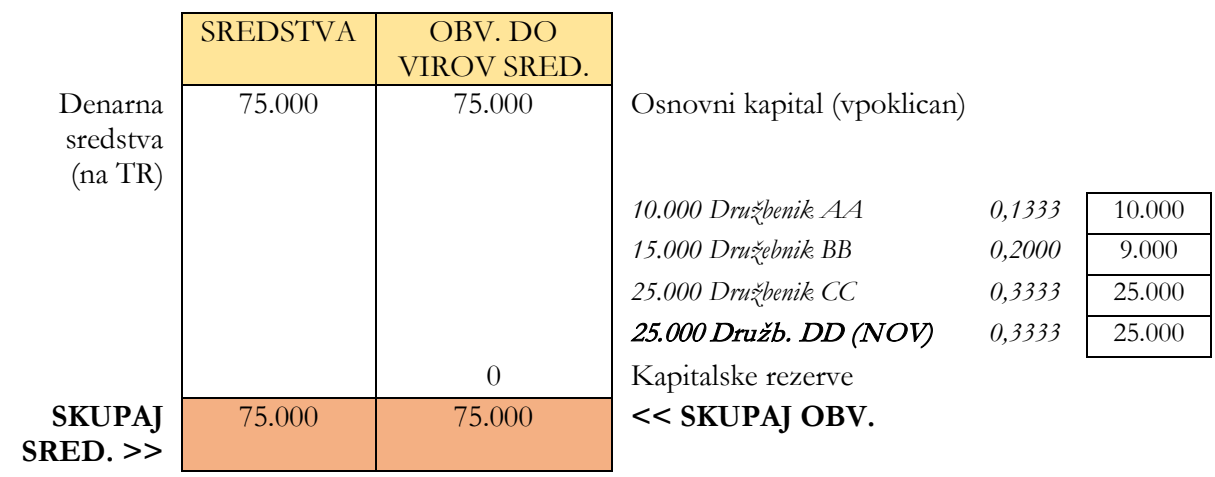

\section{Vaja G5}

Osebi AA in BB sta na začetku leta ustanovili družbo G5 d.o.o. z 10.000 EUR osnovnega kapitala. Oseba AA ima $40 \%$ poslovni delež v tej družbi, oseba BB pa $60 \%$ poslovni delež v tej družbi. Osebi AA in BB sta zagotovili celoten denarni vložek. Takoj ob ustanovitvi sta vplačali celotni denarni vložek na transakcijski račun novoustanovljene družbe. 
V družbi G5 d.o.o. se tekom leta zgodijo naslednji poslovni dogodki:

- Družba G5 d.o.o. na začetku leta kupi delnice druge družbe ZZ d.d. v skupni vrednosti 8.000 EUR. Kupljene delnice plača takoj z nakazilom denarnih sredstev s transakcijskega računa družbe prodajalcu delnic. (Opomba: stroškov $\mathrm{v}$ zvezi s prenosom delnic ni.)

- Družba G5 d.o.o. pred koncem leta prejme dividende od družbe ZZ d.d. v skupni vrednosti 1.000 EUR. Nakazilo je bilo izvršeno na transakcijski račun družbe G5 d.o.o. (Opomba: davščin v zvezi z nakazilom dividend oz. potrebe po akontaciji davščin ni.)

- Družba G5 d.o.o. je opravila storitev pravnega svetovanja (na področju korporacijskega prava in davčnega prava) v vrednosti 8.000 EUR za naročnika fizično osebo DD. Oseba DD je opravljeno storitev poplačala takoj z nakazilom na transakcijski račun družbe G5 d.o.o. Storitev pravnega svetovanja je bila t. i. intelektualna storitev. (Opomba: davščin - npr. davka na dodano vrednost - v zvezi s prodajo storitve ni.)

- Družba G5 d.o.o. je obračunala delo, ki ga je opravila pri njej zaposlena oseba EE v času izvajanja storitve. Skupna vrednost obračunanega dela je 4.000 EUR. Družba G5 d.o.o. je v zvezi z obračunanim delom izvedla nakazili s svojega transakcijskega računa osebi EE in $\mathrm{v}$ državni proračun.

- Družba G5 d.o.o. je za izvedbo storitve na področju davčnega prava naročila storitev pregleda pri izkušenem davčnem svetovalcu v vrednosti 1.000 EUR. Družba G5 d.o.o. je kupljeno storitev davčnemu svetovalcu plačala takoj z nakazilom s svojega transakcijskega računa. (Opomba: davščin - npr. davka na dodano vrednost $-\mathrm{v}$ zvezi z nakupom storitve ni.)

- Po koncu poslovnega leta vstopi v družbo nov družbenik oseba CC, ki ima nato v družbi G5 d.o.o. 50 \% delež. Družbeniki AA, BB in CC so se dogovorili, da je oseba CC vstopila v družbo z dokapitalizacijo družbe G5 d.o.o. Oseba CC vplača denarna sredstva ( $\mathrm{v}$ ustreznem znesku) v celoti na transakcijski račun družbe G5 d.o.o. 
Naloga in vprašanja (žnavodili):

- Izdelajte poenostavljeno shemo bilance stanja družbe G5 d.o.o. na začetku leta.

- Izdelajte poenostavljeno shemo izkaza poslovnega izida družbe G5 d.o.o. za poslovno leto. (Opomba: davka na dobiček - natančneje: davka od dohodka pravnih oseb - ni.)

- Če ima, katere prihodke in/ali odhodke ima družba? Koliko?

- Kateri je poslovni izid? Kolikšen?

- Izdelajte poenostavljeno shemo bilance stanja družbe G5 d.o.o. na koncu leta pred dogodkom dokapitalizacije.

- Katera sredstva (premoženje) in obveznosti (do virov sredstev) ima družba? Koliko?

- Kolikšna je knjigovodska vrednost kapitala družbe?

- Če bi družbo likvidirali, kolikšen bi bil obseg sredstev (premoženja), razpoložljivih(ega) upnikom družbe?

- Kolikšna je knjigovodska, likvidacijska in tržna vrednost poslovnega deleža vsakega družbenika v družbi?

- Izdelajte poenostavljeno shemo bilance stanja družbe G5 d.o.o. na koncu leta po dogodku dokapitalizacije.

- Kolikšen znesek mora plačati oseba CC pri dogodku dokapitalizacije? Komu?

- Katera sredstva (premoženje) in obveznosti (do virov sredstev) ima družba? Koliko?

- Kolikšna je knjigovodska vrednost kapitala družbe?

- Če bi družbo likvidirali, kolikšen bi bil obseg sredstev (premoženja), razpoložljivih(ega) upnikom družbe?

- Kolikšna je knjigovodska, likvidacijska in tržna vrednost poslovnega deleža vsakega družbenika $\mathrm{v}$ družbi?

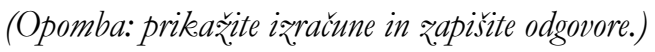




\section{Rešitev}

Izkaz poslovnega izida

\begin{tabular}{|c|c|c|c|}
\hline & ODHODKI & PRIHODKI & \\
\hline Stroški kupljenih storitev & 1.000 & 8.000 & Prihodki od prodaje storitev \\
\hline Stroški dela & 4.000 & & \\
\hline & 4.000 & 1.000 & $\begin{array}{l}\text { Finančni prihodki (od } \\
\text { prejetih dividend) }\end{array}$ \\
\hline SKUPAJ AKT. STRAN >> & 9.000 & 9.000 & $<<$ SKUPAJ PAS. STRAN \\
\hline
\end{tabular}

Bilanca stanja (PRED DOKAPITALIZACIJO)

\begin{tabular}{|c|c|c|c|}
\hline \multirow{3}{*}{$\begin{array}{r}\text { Finančna naložba (kupljene } \\
\text { delnice) } \\
\text { Denarna sredstva (na TR) }\end{array}$} & SREDSTVA & OBV. DO & \multirow[b]{2}{*}{ Osnovni kapital (vpoklican) } \\
\hline & 8.000 & 10.000 & \\
\hline & 6.000 & & 4.000 Drušbenik $A A$ \\
\hline & & 0 & 6.000 Družbenik BB \\
\hline \multirow[b]{2}{*}{ SKUPAJ SKED. } & & 4.000 & $<<$ Posl. izid (dobiček iz IPI) \\
\hline & 14.000 & 14.000 & << SKUPAJ OBV. \\
\hline
\end{tabular}


Bilanca stanja (PO DOKAPITALIZACIJI)

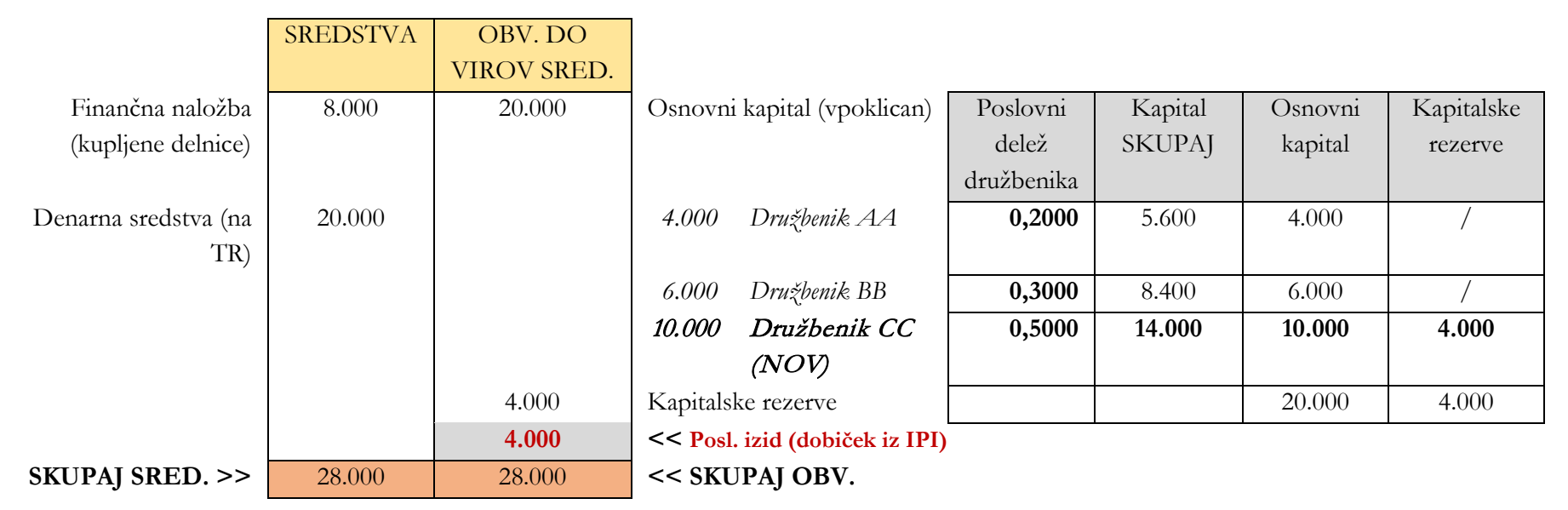




\section{Vaja G6}

Osebe AA, BB in CC so na začetku leta ustanovile družbo G6 d.o.o. z 20.000 EUR osnovnega kapitala. Oseba AA ima $50 \%$ poslovni delež v tej družbi, oseba BB 30 $\%$ in oseba CC $20 \%$ poslovni delež v tej družbi. Osebe AA, BB in CC so zagotovile 10.000 EUR, 6.000 EUR in 4.000 EUR denarnega vložka. Osebe AA, BB in CC so takoj ob ustanovitvi tudi vplačale celotni denarni vložek na transakcijski račun novoustanovljene družbe.

V družbi G6 d.o.o. se tekom leta zgodijo naslednji poslovni dogodki:

- Družba G6 d.o.o. je zaradi načrtovanega opravljanja storitev pravnega svetovanja potrebovala več računalniških in drugih pripomočkov (računalnik, tiskalnik, kopirni stroj itd.). Takoj na začetku leta je družba pripomočke v vrednosti 10.000 EUR kupila pri dobavitelju družbi RR d.o.o., kateri je poplačala takoj z nakazilom denarnih sredstev s svojega transakcijskega računa. (Opomba: davščin - npr. davka na dodano vrednost - v zvezi z nakupom pripomočkov ni.)

- Družba G6 d.o.o. je pripomočke uporabljala celo leto, zaradi česar je obračunala t. i. amortizacijo zanje v vrednosti 5.000 EUR. (Opomba: družba uporablja metodo enakomernega časovnega amortiziranja. Letna amortizacijska stopnja za računalniške pripomočke je $50 \%$.)

- Družba G6 d.o.o. na začetku leta izda obveznice v skupni vrednosti 10.000 EUR, ki jih uspešno proda. Prodane obveznice plača kupec banka BANKA d. d. takoj z nakazilom denarnih sredstev na transakcijski račun družbe G6 d.o.o. (Opomba: stroškov v zvezi z izdajo in prodajo obveznic ni.)

- Družba G6 d.o.o. pred koncem leta obračuna (kuponske) obresti iz naslova izdane obveznice v skupni vrednosti 2.000 EUR. Obresti je nakazala na transakcijski račun banke BANKA d.d. (Opomba: stroškov in davščin v zvezi z nakazilom obresti ni.)

- Družba G6 d.o.o. je opravila storitev pravnega svetovanja (na področju korporacijskega prava in davčnega prava) v vrednosti 14.000 EUR za naročnika fizično osebo EE. Oseba EE je opravljeno storitev poplačala takoj z nakazilom na transakcijski račun družbe G6 d.o.o. Storitev pravnega svetovanja je bila t. i. intelektualna storitev. (Opomba: davščin - npr. davka na dodano vrednost - v zvezi s prodajo storitve ni.) 
- Družba G6 d.o.o. je obračunala delo, ki ga je opravila pri njej zaposlena oseba FF v času izvajanja storitve. Skupna vrednost obračunanega dela je 12.000 EUR. Družba G6 d.o.o. je v zvezi z obračunanim delom izvedla nakazili s svojega transakcijskega računa osebi FF in $\mathrm{v}$ državni proračun.

- Po koncu poslovnega leta vstopi v družbo nov družbenik oseba DD, ki ima nato v družbi G6 d.o.o. 25 \% delež. Družbeniki AA, BB, CC in DD so se dogovorili, da je oseba DD vstopila v družbo z dokapitalizacijo družbe G6 d.o.o. Oseba DD vplača denarna sredstva ( $v$ ustreznem znesku) v celoti na transakcijski račun družbe G6 d.o.o.

\section{Naloga in vprašanja (z navodili):}

- Izdelajte poenostavljeno shemo bilance stanja družbe G6 d.o.o. na začetku leta.

- Izdelajte poenostavljeno shemo izkaza poslovnega izida družbe G6 d.o.o. za poslovno leto. (Opomba: davka na dobiček - natančneje: davka od dohodka pravnih oseb - ni.)

- Če ima, katere prihodke in/ali odhodke ima družba? Koliko?

- Kateri je poslovni izid? Kolikšen?

- Izdelajte poenostavljeno shemo bilance stanja družbe G6 d.o.o. na koncu leta pred dogodkom dokapitalizacije.

- Katera sredstva (premoženje) in obveznosti (do virov sredstev) ima družba? Koliko?

- Kolikšna je knjigovodska vrednost kapitala družbe?

- Če bi družbo likvidirali, kolikšen bi bil obseg sredstev (premoženja), razpoložljivih(ega) upnikom družbe?

- Kolikšna je knjigovodska, likvidacijska in tržna vrednost poslovnega deleža vsakega družbenika v družbi?

- Izdelajte poenostavljeno shemo bilance stanja družbe G6 d.o.o. na koncu leta po dogodku dokapitalizacije.

- Kolikšen znesek mora plačati oseba DD pri dogodku dokapitalizacije? Komu?

- Katera sredstva (premoženje) in obveznosti (do virov sredstev) ima družba? Koliko?

- Kolikšna je knjigovodska vrednost kapitala družbe?

- Če bi družbo likvidirali, kolikšen bi bil obseg sredstev (premoženja), razpoložljivih(ega) upnikom družbe? 
- Kolikšna je knjigovodska, likvidacijska in tržna vrednost poslovnega deleža vsakega družbenika v družbi?

(Opomba: prikařite iæračune in zapisite odgovore.)

\section{Rešitev}

Izkaz poslovnega izida

\begin{tabular}{r|c|c|c}
\cline { 2 - 3 } & ODHODKI & PRIHODKI & \multirow{2}{*}{ Prihodki od prodaje storitev } \\
\cline { 2 - 3 } Stroški amortizacije & 5.000 & 14.000 & \\
Stroški dela & 12.000 & & \\
Odhodki (str. finan.) & 2.000 & & \multirow{2}{*}{ < Izguba } \\
Dobiček $>>$ & & 5.000 & \multicolumn{1}{|c}{ < SKUPAJ PAS. STRAN }
\end{tabular}

Bilanca stanja (PRED DOKAPITALIZACIJO)

\begin{tabular}{|c|c|c|c|}
\hline \multirow{7}{*}{$\begin{array}{r}\text { Osnovna sredstva (oprema) } \\
\text { Denarna sredstva (na TR) }\end{array}$} & SREDSTVA & OBV. DO & \multirow[b]{2}{*}{ Osnovni kapital (vpoklican) } \\
\hline & \multirow{6}{*}{$\begin{array}{c}5.000 \\
20.000\end{array}$} & \multirow[t]{4}{*}{20.000} & \\
\hline & & & 10.000 Družbenik $A A$ \\
\hline & & & Družbenik $B B$ \\
\hline & & & 4.000 Družbenik CC \\
\hline & & -5.000 & \multirow{2}{*}{$\begin{array}{l}<<\text { Posl. izid (izguba iz IPI) } \\
\text { Izdane obveznice (dolžniško } \\
\text { financiranje) }\end{array}$} \\
\hline & & 10.000 & \\
\hline SKUPAJ SRED. >> & 25.000 & 25.000 & << SKUPAJ OBV. \\
\hline
\end{tabular}




\section{Bilanca stanja (PO DOKAPITALIZACIJI)}

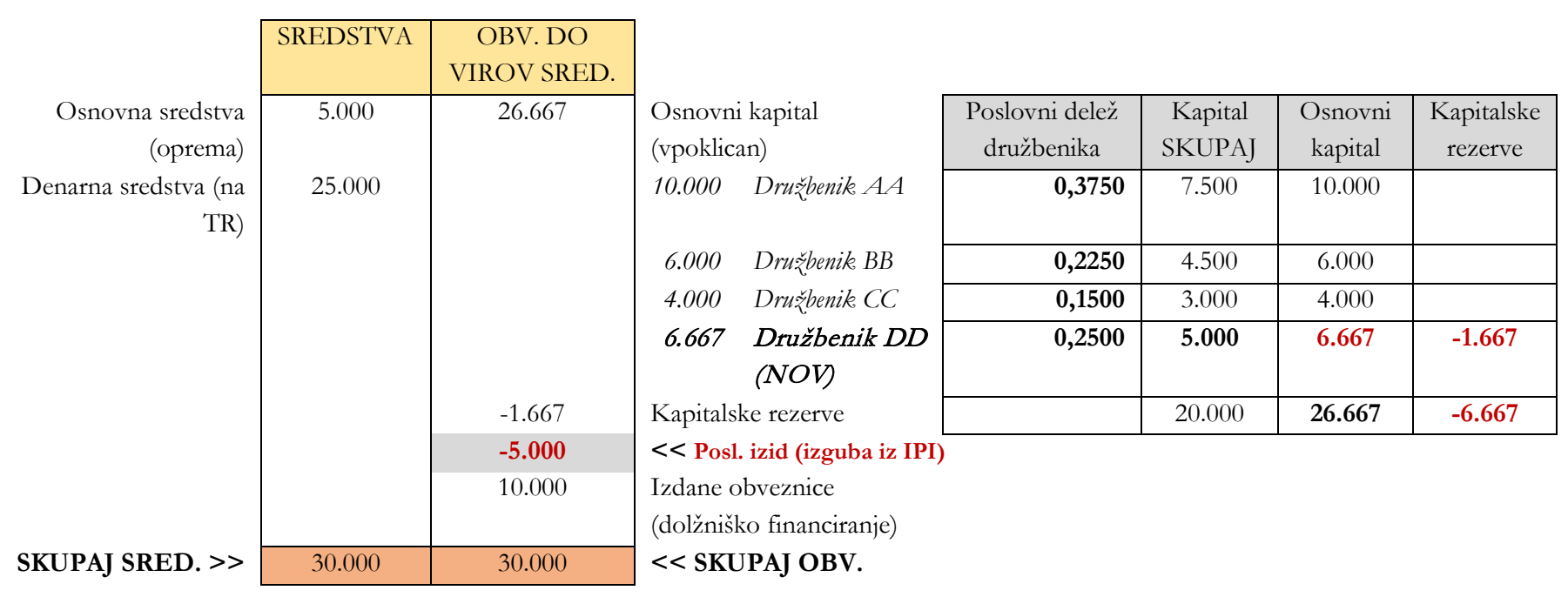




\section{Vaja G7}

Osebi $\mathrm{AA}$ in $\mathrm{BB}$ sta na začetku leta ustanovili družbo G7 d.o.o. z 10.000 EUR osnovnega kapitala. Oseba AA ima $25 \%$ poslovni delež v tej družbi, oseba BB pa $75 \%$ poslovni delež v tej družbi. Osebi $\mathrm{AA}$ in $\mathrm{BB}$ sta zagotovili celoten denarni vložek. Takoj ob ustanovitvi sta vplačali celotni denarni vložek na transakcijski račun novoustanovljene družbe.

V družbi G7 d.o.o. se tekom leta zgodijo naslednji poslovni dogodki:

- Družba G7 d.o.o. je načrtovala začetek proizvodnje izdelka (v količini 1.000 kosov). Za izdelavo takšne količine izdelkov je potreben raznovrsten material. Ves potreben material je družba v skupni vrednosti 3.000 EUR kupila pri različnih dobaviteljih, katerim je družba poplačala takoj ob nakupu z nakazilom s svojega transakcijskega računa.

- Družba G7 d.o.o. je pri proizvodnji izdelkov ves material porabila. Družba vrednoti svoje zaloge proizvedenih izdelkov po polni stroškouni ceni.27 (Opomba: na začetku leta in na koncu leta ni nobenih zalog materiala.)

- Družba G7 d.o.o. je za opravilo proizvodnje izdelkov naročila storitev opravljanja raznovrstnih del pri izkušenem proizvajalcu (kot podizvajalcu) v vrednosti 5.000 EUR. Družba G7 d.o.o. je kupljeno storitev izkušenega proizvajalca plačala takoj $\mathrm{z}$ nakazilom s svojega transakcijskega računa. (Opomba: davščin - npr. davka na dodano vrednost $-\mathrm{v}$ zvezi z nakupom storitve ni.)

- Družba G7 d.o.o. na začetku leta kupi delnice druge družbe ZZ d.d. v skupni vrednosti 8.000 EUR. Kupljene delnice plača takoj z nakazilom denarnih sredstev s transakcijskega računa družbe prodajalcu delnic. (Opomba: stroškov $\mathrm{v}$ zvezi s prenosom delnic ni.)

- Družba G7 d.o.o. pred koncem leta prejme dividende od družbe ZZ d.d. v skupni vrednosti 1.000 EUR. Nakazilo je bilo izvršeno na transakcijski račun družbe G7 d.o.o. (Opomba: davščin v zvezi z nakazilom dividend oz. potrebe po akontaciji davščin ni.)

- Družba G7 d.o.o. je prodala celotno zalogo proizvedenih izdelkov kupcu MINI d.o.o. Kupec je poplačal kupljene proizvedene izdelke v vrednosti 12.000 EUR

\footnotetext{
${ }_{27}$ Obstaja več različnih metod vrednotenja zalog proizvodov oz. učinkov v podjetju. Podrobneje o tem glejte opombo 1.
} 
takoj z nakazilom na transakcijski račun družbe G7 d.o.o. (Opomba: davščin npr. davka na dodano vrednost $-\mathrm{v}$ zvezi s prodajo proizvedenih izdelkov ni.)

- Po koncu poslovnega leta vstopi v družbo nov družbenik oseba CC, ki ima nato v družbi G7 d.o.o. 40 \% delež. Družbeniki AA, BB in CC so se dogovorili, da je oseba CC vstopila v družbo z dokapitalizacijo družbe G7 d.o.o. Oseba CC vplača denarna sredstva ( $v$ ustreznem znesku) v celoti na transakcijski račun družbe G7 d.o.o.

\section{Naloga in uprašanja (z navodili):}

- Izdelajte poenostavljeno shemo bilance stanja družbe G7 d.o.o. na začetku leta.

- Izdelajte poenostavljeno shemo izkaza poslovnega izida družbe G7 d.o.o. za poslovno leto. (Opomba: davka na dobiček - natančneje: davka od dohodka pravnih oseb - ni.)

- Če ima, katere prihodke in/ali odhodke ima družba? Koliko?

- Kateri je poslovni izid? Kolikšen?

- Izdelajte poenostavljeno shemo bilance stanja družbe G7 d.o.o. na koncu leta pred dogodkom dokapitalizacije.

- Katera sredstva (premoženje) in obveznosti (do virov sredstev) ima družba? Koliko?

- Kolikšna je knjigovodska vrednost kapitala družbe?

- Če bi družbo likvidirali, kolikšen bi bil obseg sredstev (premoženja), razpoložljivih(ega) upnikom družbe?

- Kolikšna je knjigovodska, likvidacijska in tržna vrednost poslovnega deleža vsakega družbenika v družbi?

- Izdelajte poenostavljeno shemo bilance stanja družbe G7 d.o.o. na koncu leta po dogodku dokapitalizacije.

- Kolikšen znesek mora plačati oseba CC pri dogodku dokapitalizacije? Komu?

- Katera sredstva (premoženje) in obveznosti (do virov sredstev) ima družba? Koliko?

- Kolikšna je knjigovodska vrednost kapitala družbe?

- Če bi družbo likvidirali, kolikšen bi bil obseg sredstev (premoženja), razpoložljivih(ega) upnikom družbe?

- Kolikšna je knjigovodska, likvidacijska in tržna vrednost poslovnega deleža vsakega družbenika v družbi? 
(Opomba: prikažite iæračune in zapisite odgovore.)

Rešitev

Izkaz poslovnega izida

\begin{tabular}{|c|c|c|c|}
\hline \multirow{3}{*}{$\begin{array}{r}\text { Odhodki (stroškovna vrednost } \\
\text { prod. proizv.): } \\
\text { Odhodki (stroški porabljenega } \\
\text { materiala) }\end{array}$} & ODHODKI & PRIHODKI & \multirow{3}{*}{$\begin{array}{l}\text { Prihodki od prodaje } \\
\text { proizvodov } \\
\text { Finančni prihodki (prejete } \\
\text { dividende) }\end{array}$} \\
\hline & & 12.000 & \\
\hline & 3.000 & 1.000 & \\
\hline Odhodki (stroški kupljene storitve) & 5.000 & & \\
\hline Dobiček >> & 5.000 & & $<$ Izguba \\
\hline SKUPAJ AKT. STRAN >> & 13.000 & 13.000 & $<<$ SKUPAJ PAS. STRAN \\
\hline
\end{tabular}

Bilanca stanja (PRED DOKAPITALIZACIJO)

\begin{tabular}{|c|c|c|c|}
\hline \multirow{3}{*}{$\begin{array}{r}\text { Finančna naložba (kupljene } \\
\text { delnice) } \\
\text { Denarna sredstva (na TR) }\end{array}$} & SREDSTVA & $\begin{array}{c}\text { OBV. DO } \\
\text { VIROV SRED. }\end{array}$ & \multirow[b]{2}{*}{ Osnovni kapital (vpoklican) } \\
\hline & 8.000 & 10.000 & \\
\hline & 7.000 & & 2.500 Drušbenik $A A$ \\
\hline \multirow[b]{3}{*}{ SKUPAJ SRED. >> } & & 0 & $\begin{array}{l}7.500 \text { Drušbenik BB } \\
\text { Kapitalske rezerve }\end{array}$ \\
\hline & & 5.000 & $<<$ Posl. izid (dobiček iz IPI) \\
\hline & 15.000 & 15.000 & $<<$ SKUPAJ OBV. \\
\hline
\end{tabular}


Bilanca stanja (PO DOKAPITALIZACIJI)

\begin{tabular}{|c|c|c|c|c|c|c|c|c|}
\hline \multirow{7}{*}{$\begin{array}{r}\text { Finančna naložba (kupljene } \\
\text { delnice) } \\
\text { Denarna sredstva (na TR) }\end{array}$} & SREDSTVA & $\begin{array}{l}\text { OBV. DO } \\
\text { VIROV } \\
\text { SRED. }\end{array}$ & \multirow[b]{2}{*}{$\begin{array}{l}\text { Osnovni kapital } \\
\text { (vpoklican) }\end{array}$} & \multirow[b]{2}{*}{$\begin{array}{c}\text { Poslovni delež } \\
\text { družbenika }\end{array}$} & \multirow[b]{2}{*}{$\begin{array}{l}\text { Kapital } \\
\text { SKUPAJ }\end{array}$} & \multirow[b]{2}{*}{$\begin{array}{c}\text { Osnovni } \\
\text { kapital }\end{array}$} & \multirow[b]{2}{*}{ Razlika } & \multirow[b]{2}{*}{$\begin{array}{l}\text { DODATNO } \\
\text { v kap. Rez. }\end{array}$} \\
\hline & 8.000 & \multirow[t]{4}{*}{16.667} & & & & & & \\
\hline & 17.000 & & 2.500 Družbenik $A A$ & 0,1500 & 3.750 & 2.500 & 1.250 & \\
\hline & & & 7.500 Družbenik. BB & 0,4500 & 11.250 & 7.500 & 3.750 & \\
\hline & & & $\begin{array}{cl}6.667 & \text { Družbenik CC } \\
\text { (NOV) }\end{array}$ & 0,4000 & 10.000 & 6.667 & & 3.333 \\
\hline & & 3.333 & Kapitalske rezerve & & 25.000 & 16.667 & 5.000 & 3.333 \\
\hline & & 5.000 & $\begin{array}{l}<<\text { Posl. izid (dobiček iz } \\
\text { IPI) }\end{array}$ & & & & & \\
\hline SKUPAJ SRED. >> & 25.000 & 25.000 & << SKUPAJ OBV. & & & & & \\
\hline
\end{tabular}




\section{Vaja G8}

Osebe AA, BB in CC so na začetku leta ustanovile družbo G8 d.o.o. s 30.000 EUR osnovnega kapitala. Oseba AA ima $50 \%$ poslovni delež v tej družbi, oseba BB 30 $\%$ in oseba CC $20 \%$ poslovni delež v tej družbi. Osebe AA, BB in CC so zagotovile 15.000 EUR, 9.000 EUR in 6.000 EUR denarnega vložka. Osebe AA, BB in CC so takoj ob ustanovitvi tudi vplačale celotni denarni vložek na transakcijski račun novoustanovljene družbe.

V družbi G8 d.o.o. se tekom leta zgodijo naslednji poslovni dogodki:

- Družba G8 d.o.o. je načrtovala začetek proizvodnje izdelka (v količini 5.000 kosov). Za izdelavo takšne količine izdelkov je potreben raznovrsten material. Ves potreben material je družba v skupni vrednosti 15.000 EUR kupila pri različnih dobaviteljih, katerim je družba poplačala takoj ob nakupu z nakazilom s svojega transakcijskega računa.

- Družba G8 d.o.o. je zaradi načrtovane proizvodnje potrebovala poseben stroj/napravo. Takoj na začetku leta je družba stroj/napravo v vrednosti 12.000 EUR kupila pri dobavitelju družbi PP d.o.o., kateri je poplačala takoj z nakazilom denarnih sredstev s svojega transakcijskega računa. (Opomba: davščin - npr. davka na dodano vrednost - v zvezi z nakupom stroja/naprave ni.)

- Družba G8 d.o.o. je stroj/napravo uporabljala celo leto, zaradi česar je obračunala t. i. amortizacijo zanj(o) v vrednosti 3.000 EUR. (Opomba: družba uporablja metodo enakomernega časovnega amortiziranja. Letna amortizacijska stopnja za stroj/napravo je $25 \%$.)

- Družba G8 d.o.o. je pri proizvodnji izdelkov ves material porabila. Družba vrednoti svoje zaloge proizvedeih izdelkov po polni stroškovni ceni. ${ }^{28}$ (Opomba: na začetku leta in na koncu leta ni nobenih zalog materiala.)

- Družba G8 d.o.o. je obračunala delo, ki ga je opravila pri njej zaposlena oseba EE v času proizvodnje izdelka (v količini 5.000 kosov). Skupna vrednost obračunanega dela je 10.000 EUR. (Opomba: družba vrednoti svoje zaloge izdelkov po polni stroškovni ceni.) Družba G8 d.o.o. je v zvezi z obračunanim delom izvedla nakazili s svojega transakcijskega računa osebi EE in v državni proračun.

\footnotetext{
${ }^{28}$ Obstaja več različnih metod vrednotenja zalog proizvodov oz. učinkov v podjetju. Podrobneje o tem glejte opombo 1 (na strani 19).
} 
- Družba G8 d.o.o. je prodala celotno zalogo proizvedenega izdelka kupcu NIMI d.o.o. Kupec je poplačal opravljen nakup v vrednosti 37.000 EUR takoj z nakazilom na transakcijski račun družbe G8 d.o.o. (Opomba: davščin - npr. davka na dodano vrednost $-\mathrm{v}$ zvezi s prodajo proizvedenega izdelka ni.)

- Po koncu poslovnega leta vstopi v družbo nov družbenik oseba DD, ki ima nato v družbi G8 d.o.o. 25 \% delež. Družbeniki AA, BB, CC in DD so se dogovorili, da je oseba DD vstopila v družbo z dokapitalizacijo družbe G8 d.o.o. Oseba DD vplača denarna sredstva (v ustreznem znesku) v celoti na transakcijski račun družbe G8 d.o.o.

\section{Naloga in vprašanja (₹. navodili):}

- Izdelajte poenostavljeno shemo bilance stanja družbe G8 d.o.o. na začetku leta.

- Izdelajte poenostavljeno shemo izkaza poslovnega izida družbe G8 d.o.o. za poslovno leto. (Opomba: davka na dobiček - natančneje: davka od dohodka pravnih oseb - ni.)

- Če ima, katere prihodke in/ali odhodke ima družba? Koliko?

- Kateri je poslovni izid? Kolikšen?

- Izdelajte poenostavljeno shemo bilance stanja družbe G8 d.o.o. na koncu leta pred dogodkom dokapitalizacije.

- Katera sredstva (premoženje) in obveznosti (do virov sredstev) ima družba? Koliko?

- Kolikšna je knjigovodska vrednost kapitala družbe?

- Če bi družbo likvidirali, kolikšen bi bil obseg sredstev (premoženja), razpoložljivih(ega) upnikom družbe?

- Kolikšna je knjigovodska, likvidacijska in tržna vrednost poslovnega deleža vsakega družbenika v družbi?

- Izdelajte poenostavljeno shemo bilance stanja družbe G8 d.o.o. na koncu leta po dogodku dokapitalizacije.

- Kolikšen znesek mora plačati oseba DD pri dogodku dokapitalizacije? Komu?

- Katera sredstva (premoženje) in obveznosti (do virov sredstev) ima družba? Koliko?

- Kolikšna je knjigovodska vrednost kapitala družbe?

- Če bi družbo likvidirali, kolikšen bi bil obseg sredstev (premoženja), razpoložljivih(ega) upnikom družbe? 
- Kolikšna je knjigovodska, likvidacijska in tržna vrednost poslovnega deleža vsakega družbenika v družbi?

(Opomba: prikažite iæračune in zapisite odgovore.)

\section{Rešitev}

Izkaz poslovnega izida

\begin{tabular}{|c|c|c|c|}
\hline \multirow{3}{*}{$\begin{array}{r}\text { Odhodki (stroškovna vrednost } \\
\text { prod. proizv.): } \\
\text { Odhodki (stroški porabljenega } \\
\text { materiala) }\end{array}$} & ODHODKI & PRIHODKI & \multirow[b]{2}{*}{$\begin{array}{l}\text { Prihodki od prodaje } \\
\text { proizvodov }\end{array}$} \\
\hline & & 37.000 & \\
\hline & 15.000 & & \\
\hline Stroškei dela & 10.000 & & \\
\hline Stroški amortizacije & 3.000 & & \\
\hline Dobiček >> & 9.000 & & $<<$ Izguba \\
\hline SKUPAJ AKT. STRAN >> & 37.000 & 37.000 & $<<$ SKUPAJ PAS. STRAN \\
\hline
\end{tabular}

Bilanca stanja (PRED DOKAPITALIZACIJO)

\begin{tabular}{|c|c|c|c|}
\hline \multirow{6}{*}{$\begin{array}{r}\text { Osnovna sredstva (oprema) } \\
\text { Denarna sredstva (na TR) }\end{array}$} & SREDSTVA & $\begin{array}{c}\text { OBV. DO } \\
\text { VIROV SRED. }\end{array}$ & \multirow[b]{2}{*}{ Osnovni kapital (vpoklican) } \\
\hline & \multirow{5}{*}{$\begin{array}{c}9.000 \\
30.000\end{array}$} & \multirow[t]{4}{*}{30.000} & \\
\hline & & & 15.000 Druø̌benik $A A$ \\
\hline & & & Družbenik BB \\
\hline & & & Druăbenik CC \\
\hline & & 9.000 & \multirow{2}{*}{$\begin{array}{l}<\text { Posl izid (dobiček iz IPI) } \\
<<\text { SKUPAJ OBV. }\end{array}$} \\
\hline SKUPAJ SRED. >> & 39.000 & 39.000 & \\
\hline
\end{tabular}


Bilanca stanja (PO DOKAPITALIZACIJI)

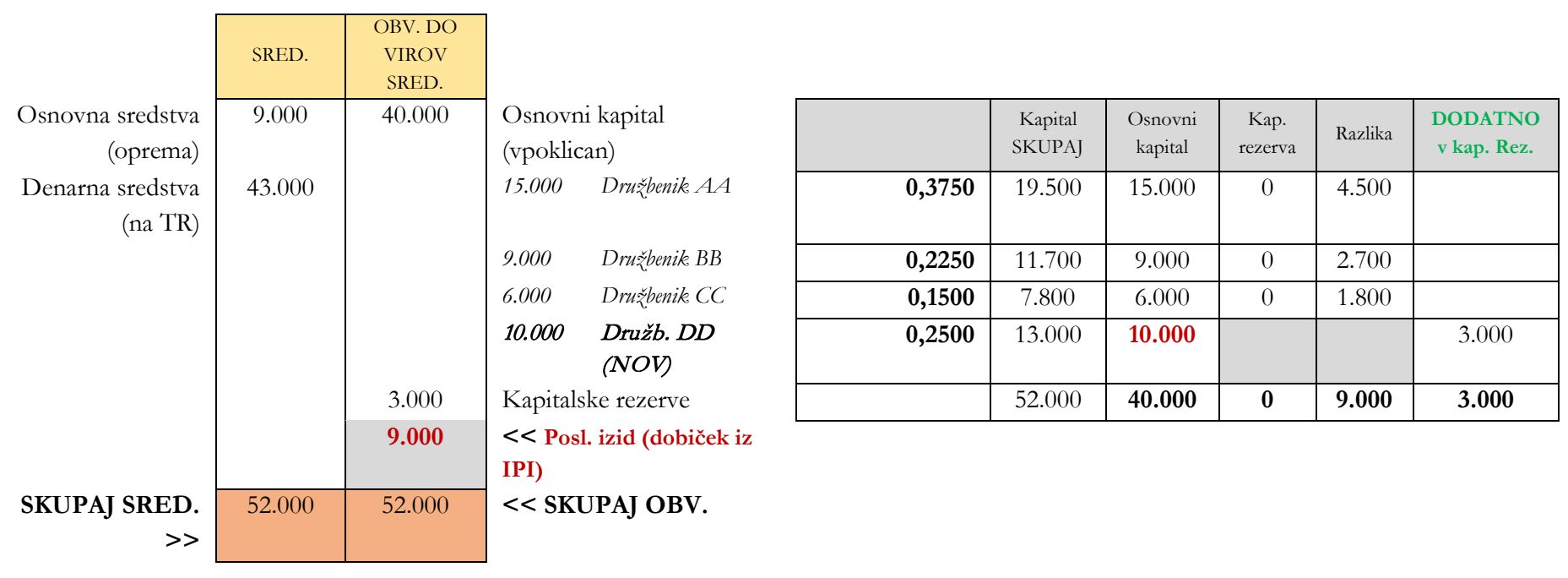




\section{Vaja G9}

Osebi AA in BB sta na začetku leta ustanovili družbo G9 d.o.o. z 10.000 EUR osnovnega kapitala. Oseba AA ima $40 \%$ poslovni delež v tej družbi, oseba BB pa $60 \%$ poslovni delež v tej družbi. Osebi AA in BB sta zagotovili celoten denarni vložek. Takoj ob ustanovitvi sta vplačali celotni denarni vložek na transakcijski račun novoustanovljene družbe.

V družbi G9 d.o.o. se tekom leta zgodijo naslednji poslovni dogodki:

- Poslovodstvo družbe G9 d.o.o. je takoj po ustanovitvi odobrilo posojilo v višini 9.000 EUR (nepovezani) družbi KARTA d.o.o. Družba kot posojilodajalec je tudi nakazala posojilo družbi posojilojemalki na njen transakcijski račun. (Opomba: stroškov v zvezi z odobritvijo in nakazilom posojila ni.)

- Družba G9 d.o.o. pred koncem leta obračuna obresti iz naslova danega posojila v skupni vrednosti 1.000 EUR. Obresti je prejela nakazane na svoj transakcijski račun s strani posojilojemalke družbe KARTA d.o.o. (Opomba: stroškov in davščin v zvezi s prejemom nakazila obresti ni.)

- Družba G9 d.o.o. je opravila storitev pravnega svetovanja (na področju korporacijskega prava in davčnega prava) v vrednosti 15.000 EUR za naročnika fizično osebo DD. Oseba DD je opravljeno storitev poplačala takoj z nakazilom na transakcijski račun družbe G9 d.o.o. Storitev pravnega svetovanja je bila t. i. intelektualna storitev. (Opomba: davščin - npr. davka na dodano vrednost - v zvezi s prodajo storitve ni.)

- Družba G9 d.o.o. je obračunala delo, ki ga je opravila pri njej zaposlena oseba EE v času izvajanja storitve. Skupna vrednost obračunanega dela je 10.000 EUR. Družba G9 d.o.o. je v zvezi z obračunanim delom izvedla nakazili s svojega transakcijskega računa osebi EE in $\mathrm{v}$ državni proračun.

- Družba G9 d.o.o. je za izvedbo storitve na področju davčnega prava naročila storitev pregleda pri izkušenem davčnem svetovalcu v vrednosti 1.000 EUR. Družba G9 d.o.o. je kupljeno storitev davčnemu svetovalcu plačala takoj z nakazilom s svojega transakcijskega računa. (Opomba: davščin - npr. davka na dodano vrednost $-\mathrm{v}$ zvezi z nakupom storitve ni.)

- Po koncu poslovnega leta vstopi v družbo nov družbenik oseba CC, ki ima nato v družbi G9 d.o.o. enak poslovni delež kot oseba BB (tj. po obsegu sta njuna deleža enaka). Družbeniki AA, BB in CC so se dogovorili, da je oseba CC 
vstopila v družbo z dokapitalizacijo družbe G9 d.o.o. Oseba CC vplača denarna sredstva (v ustreznem znesku) v celoti na transakcijski račun družbe G9 d.o.o.

Naloga in vprašanja (z.navodili):

- Izdelajte poenostavljeno shemo bilance stanja družbe G9 d.o.o. na začetku leta.

- Izdelajte poenostavljeno shemo izkaza poslovnega izida družbe G9 d.o.o. za poslovno leto. (Opomba: davka na dobiček - natančneje: davka od dohodka pravnih oseb - ni.)

- Če ima, katere prihodke in/ali odhodke ima družba? Koliko?

- Kateri je poslovni izid? Kolikšen?

- Izdelajte poenostavljeno shemo bilance stanja družbe G9 d.o.o. na koncu leta pred dogodkom dokapitalizacije.

- Katera sredstva (premoženje) in obveznosti (do virov sredstev) ima družba? Koliko?

- Kolikšna je knjigovodska vrednost kapitala družbe?

- Če bi družbo likvidirali, kolikšen bi bil obseg sredstev (premoženja), razpoložljivih(ega) upnikom družbe?

- Kolikšna je knjigovodska, likvidacijska in tržna vrednost poslovnega deleža vsakega družbenika v družbi?

- Izdelajte poenostavljeno shemo bilance stanja družbe G9 d.o.o. na koncu leta po dogodku dokapitalizacije.

- Kolikšen znesek mora plačati oseba CC pri dogodku dokapitalizacije? Komu?

- Katera sredstva (premoženje) in obveznosti (do virov sredstev) ima družba? Koliko?

- Kolikšna je knjigovodska vrednost kapitala družbe?

- Če bi družbo likvidirali, kolikšen bi bil obseg sredstev (premoženja), razpoložljivih(ega) upnikom družbe?

- Kolikšna je knjigovodska, likvidacijska in tržna vrednost poslovnega deleža vsakega družbenika v družbi?

(Opomba: prikařite izračune in zapisite odgovore.) 


\section{Rešitev}

Izkaz poslovnega izida

\begin{tabular}{|c|c|c|c|}
\hline \multirow[b]{2}{*}{ Stroški kupljenih storitev } & ODHODKI & PRIHODKI & \multirow[b]{2}{*}{ Prihodki od prodaje storitev } \\
\hline & 1.000 & 15.000 & \\
\hline Stroški dela & 10.000 & 1.000 & $\begin{array}{l}\text { Finančni prihodki (prejete } \\
\text { dividende) }\end{array}$ \\
\hline Dobiček >> & 5.000 & & $<<$ Izguba \\
\hline KUPAJ AKT. STRAN >> & 16.000 & 16.000 & $<<$ SKUPAJ PAS. STRAN \\
\hline
\end{tabular}

Bilanca stanja (PRED DOKAPITALIZACIJO)

\begin{tabular}{|c|c|c|c|}
\hline \multirow{3}{*}{$\begin{array}{r}\text { Finančna naložba (dano } \\
\text { posojilo) } \\
\text { Denarna sredstva (na TR) }\end{array}$} & SREDSTVA & $\begin{array}{c}\text { OBV. DO } \\
\text { VIROV SRED. }\end{array}$ & \multirow[b]{2}{*}{ Osnovni kapital (vpoklican) } \\
\hline & 9.000 & 10.000 & \\
\hline & 6.000 & & $\begin{array}{ll}4.000 & \text { Družbenik } A A \\
6.000 & \text { Drušbenik } B B\end{array}$ \\
\hline \multirow[b]{2}{*}{ SKUPAJ SRED. >> } & & 5.000 & $<<$ Posl. izid (dobiček iz IPI) \\
\hline & 15.000 & 15.000 & $<<$ SKUPAJ OBV. \\
\hline
\end{tabular}




\section{Bilanca stanja (PO DOKAPITALIZACIJI)}

\begin{tabular}{|c|c|c|c|c|c|c|c|c|c|}
\hline \multirow{3}{*}{$\begin{array}{r}\text { Finančna naložba } \\
\text { (dano posojilo) } \\
\text { Denarna sredstva } \\
\text { (na TR) }\end{array}$} & SREDSTVA & $\begin{array}{l}\text { OBV. DO } \\
\text { VIROV } \\
\text { SRED. } \\
\end{array}$ & \multirow[b]{2}{*}{$\begin{array}{l}\text { Osnovni kapital } \\
\text { (vpoklican) }\end{array}$} & & & & & & \\
\hline & 9.000 & \multirow[t]{4}{*}{16.000} & & $\begin{array}{c}\text { Poslovni delež } \\
\text { družbenika }\end{array}$ & $\begin{array}{l}\text { Kapital } \\
\text { SKUPAJ }\end{array}$ & $\begin{array}{c}\text { Osnovni } \\
\text { kapital }\end{array}$ & $\begin{array}{l}\text { Kap. } \\
\text { rezerva }\end{array}$ & Razlika & $\begin{array}{l}\text { DODATNO } \\
\text { v kap. Rez. }\end{array}$ \\
\hline & \multirow[t]{5}{*}{15.000} & & 4.000 Dru乏̌benik. $A A$ & 0,2500 & 6.000 & 4.000 & 0 & 2.000 & \\
\hline \multirow[b]{5}{*}{$\begin{array}{r}\text { SKUPAJ SRED. } \\
>>\end{array}$} & & & 6.000 Družbenik. BB & 0,3750 & 9.000 & 6.000 & 0 & 3.000 & \\
\hline & & & $\begin{array}{l}6.000 \text { Družbenik CC } \\
\text { (NOV) }\end{array}$ & 0,3750 & 9.000 & 6.000 & 0 & 0 & 3.000 \\
\hline & & 3.000 & Kapitalske rezerve & & 24.000 & 16.000 & 0 & 5.000 & 3.000 \\
\hline & & 5.000 & \multirow{2}{*}{\multicolumn{7}{|c|}{$\begin{array}{l}<<\text { Posl. izid (dobiček iz IPI) } \\
<<\text { SKUPAJ OBV. }\end{array}$}} \\
\hline & 24.000 & 24.000 & & & & & & & \\
\hline
\end{tabular}




\section{Vaja G10}

Osebe AA, BB in CC so na začetku leta ustanovile družbo G10 d.o.o. s 30.000 EUR osnovnega kapitala. Osebe AA, BB in CC imajo vsak tretjinski poslovni delež v tej družbi. Osebe AA, BB in CC so zagotovile vsak 13.000 EUR denarnega vložka. Osebe AA, BB in CC so takoj ob ustanovitvi tudi vplačale celotni denarni vložek na transakcijski račun novoustanovljene družbe.

V družbi G10 d.o.o. se tekom leta zgodijo naslednji poslovni dogodki:

- Družba G10 d.o.o. je načrtovala začetek proizvodnje izdelka (v količini 5.000 kosov). Za izdelavo takšne količine izdelkov je potreben raznovrsten material. Ves potreben material je družba v skupni vrednosti 15.000 EUR kupila pri različnih dobaviteljih, katerim je družba poplačala takoj ob nakupu z nakazilom s svojega transakcijskega računa.

- Družba G10 d.o.o. je zaradi načrtovane proizvodnje potrebovala poseben stroj/napravo. Takoj na začetku leta je družba stroj/napravo v vrednosti 12.000 EUR kupila pri dobavitelju družbi PP d.o.o., kateri je poplačala takoj z nakazilom denarnih sredstev $s$ svojega transakcijskega računa. (Opomba: davščin - npr. davka na dodano vrednost - v zvezi z nakupom stroja/naprave ni.)

- Družba G10 d.o.o. je stroj/napravo uporabljala celo leto, zaradi česar je obračunala t. i. amortizacijo zanj(o) v vrednosti 3.000 EUR. (Opomba: družba uporablja metodo enakomernega časovnega amortiziranja. Letna amortizacijska stopnja za stroj/napravo je $25 \%$.)

- Družba G10 d.o.o. je pri proizvodnji izdelkov ves material porabila. Družba vrednoti svoje zaloge proizvedenih izdelkov po polni stroškouni ceni. ${ }^{29}$ (Opomba: na začetku leta in na koncu leta ni nobenih zalog materiala.)

- Družba G10 d.o.o. je obračunala delo, ki ga je opravila pri njej zaposlena oseba EE v času proizvodnje izdelka (v količini 5.000 kosov). Skupna vrednost obračunanega dela je 10.000 EUR. (Opomba: družba vrednoti svoje zaloge izdelkov po polni stroškovni ceni.) Družba G10 d.o.o. je v zvezi z obračunanim delom izvedla nakazili s svojega transakcijskega računa osebi EE in v državni proračun.

\footnotetext{
${ }^{29}$ Obstaja več različnih metod vrednotenja zalog proizvodov oz. učinkov v podjetju. Podrobneje o tem glejte opombo 1 (na strani 19).
} 
- Družba G10 d.o.o. je prodala celotno zalogo proizvedenega izdelka kupcu NIMI d.o.o. Kupec je poplačal opravljen nakup v vrednosti 34.000 EUR takoj z nakazilom na transakcijski račun družbe G10 d.o.o. (Opomba: davščin - npr. davka na dodano vrednost $-\mathrm{v}$ zvezi s prodajo proizvedenega izdelka ni.)

- Po koncu poslovnega leta vstopi v družbo nov družbenik oseba DD, ki ima nato v družbi G10 d.o.o. enak poslovni delež kot oseba CC (tj. po obsegu sta njuna deleža enaka). Družbeniki AA, BB, CC in DD so se dogovorili, da je oseba DD vstopila v družbo z dokapitalizacijo družbe G10 d.o.o. Oseba DD vplača denarna sredstva ( $v$ ustreznem znesku) v celoti na transakcijski račun družbe G10 d.o.o.

Naloga in uprašanja (z navodili):

- Izdelajte poenostavljeno shemo bilance stanja družbe G10 d.o.o. na začetku leta.

- Izdelajte poenostavljeno shemo izkaza poslovnega izida družbe G10 d.o.o. za poslovno leto. (Opomba: davka na dobiček - natančneje: davka od dohodka pravnih oseb - ni.)

- Če ima, katere prihodke in/ali odhodke ima družba? Koliko?

- Kateri je poslovni izid? Kolikšen?

- Izdelajte poenostavljeno shemo bilance stanja družbe G10 d.o.o. na koncu leta - pred dogodkom dokapitalizacije.

- Katera sredstva (premoženje) in obveznosti (do virov sredstev) ima družba? Koliko?

- Kolikšna je knjigovodska vrednost kapitala družbe?

- Če bi družbo likvidirali, kolikšen bi bil obseg sredstev (premoženja), razpoložljivih(ega) upnikom družbe?

- Kolikšna je knjigovodska, likvidacijska in tržna vrednost poslovnega deleža vsakega družbenika v družbi?

- Izdelajte poenostavljeno shemo bilance stanja družbe G10 d.o.o. na koncu leta - po dogodku dokapitalizacije.

- Oseba DD mora pri dogodku dokapitalizacije plačati kolikšen znesek? Komu?

- Katera sredstva (premoženje) in obveznosti (do virov sredstev) ima družba? Koliko?

- Kolikšna je knjigovodska vrednost kapitala družbe? 
- Če bi družbo likvidirali, kolikšen bi bil obseg sredstev (premoženja), razpoložljivih(ega) upnikom družbe?

- Kolikšna je knjigovodska, likvidacijska in tržna vrednost poslovnega deleža vsakega družbenika $\mathrm{v}$ družbi?

(Opomba: prikažite izračune in zapišite odgovore.)

\section{Rešitev}

Izkaz poslovnega izida

\begin{tabular}{|c|c|c|c|}
\hline \multirow[b]{2}{*}{ Stroški amortizacije } & ODHODKI & PRIHODKI & \multirow[b]{2}{*}{$\begin{array}{l}\text { Prihodki od prodaje } \\
\text { proizvodov }\end{array}$} \\
\hline & 3.000 & 34.000 & \\
\hline Stroški porabljenega mat. & 15.000 & & \\
\hline Stroški dela & 10.000 & & \\
\hline Dobiček >> & 6.000 & & $<<$ Izguba \\
\hline SKUPAJ AKT. STRAN >> & 34.000 & 34.000 & $<<$ SKUPAJ PAS. STRAN \\
\hline
\end{tabular}

Bilanca stanja (PRED DOKAPITALIZACIJO)

\begin{tabular}{|c|c|c|c|}
\hline \multirow{7}{*}{$\begin{array}{l}\text { Osnovna sredstva (oprema) } \\
\text { Denarna sredstva (na TR) }\end{array}$} & SREDSTVA & $\begin{array}{c}\text { OBV. DO } \\
\text { VIROV SRED. }\end{array}$ & \multirow[b]{2}{*}{ Osnovni kapital (vpoklican) } \\
\hline & \multirow{6}{*}{$\begin{array}{c}9.000 \\
36.000\end{array}$} & \multirow[t]{4}{*}{30.000} & \\
\hline & & & 10.000 Drušbenik $A A$ \\
\hline & & & 10.000 Drǔ̌benik BB \\
\hline & & & 10.000 Drušbenik CC \\
\hline & & 9.000 & Kapitalske rezerve \\
\hline & & 6.000 & $<<$ Posl. izid (dobiček iz IPI) \\
\hline SKUPAJ SRED. >> & 45.000 & 45.000 & << SKUPAJ OBV. \\
\hline
\end{tabular}




\section{Bilanca stanja (PO DOKAPITALIZACIJI)}

\begin{tabular}{|c|c|c|c|c|c|c|c|c|c|}
\hline \multirow{3}{*}{$\begin{array}{r}\text { Osnovna sredstva } \\
\text { (oprema) } \\
\text { Denarna sredstva } \\
\text { (na TR) }\end{array}$} & SREDSTVA & $\begin{array}{l}\text { OBV. DO } \\
\text { VIROV } \\
\text { SRED. }\end{array}$ & \multirow[b]{2}{*}{$\begin{array}{l}\text { Osnovni kapital } \\
\text { (vpoklican) }\end{array}$} & \multirow[b]{2}{*}{$\begin{array}{l}\text { Poslovni delež } \\
\text { družbenika }\end{array}$} & \multirow[b]{2}{*}{$\begin{array}{l}\text { Kapital } \\
\text { SKUPAJ }\end{array}$} & \multirow[b]{2}{*}{$\begin{array}{l}\text { Osnovni } \\
\text { kapital }\end{array}$} & \multirow[b]{2}{*}{$\begin{array}{l}\text { Kap. } \\
\text { rezerve }\end{array}$} & \multirow[b]{2}{*}{ Razlika } & \multirow[b]{2}{*}{$\begin{array}{l}\text { DODAT. v } \\
\text { kap. rez. }\end{array}$} \\
\hline & 9.000 & \multirow[t]{5}{*}{40.000} & & & & & & & \\
\hline & \multirow[t]{6}{*}{51.000} & & 10.000 Družbenik. $A A$ & 0,2500 & 15.000 & 10.000 & 3.000 & 2.000 & \\
\hline \multirow[b]{6}{*}{$\begin{array}{r}\text { SKUPAJ SRED. } \\
>>\end{array}$} & & & 10.000 Družbenik BB & 0,2500 & 15.000 & 10.000 & 3.000 & 2.000 & \\
\hline & & & 10.000 Druそ̌benik CC & 0,2500 & 15.000 & 10.000 & 3.000 & 2.000 & \\
\hline & & & $\begin{array}{c}10.000 \text { Družbenik DD } \\
\text { (NOV) }\end{array}$ & 0,2500 & 15.000 & 10.000 & & & 5.000 \\
\hline & & 14.000 & Kapitalske rezerve & & 60.000 & 40.000 & 9.000 & 6.000 & 5.000 \\
\hline & & 6.000 & \multirow{2}{*}{\multicolumn{7}{|c|}{$\begin{array}{l}<<\text { Posl. izid (dobiček iz IPI) } \\
<<\text { SKUPAJ OBV. }\end{array}$}} \\
\hline & 60.000 & 60.000 & & & & & & & \\
\hline
\end{tabular}




\section{SKLOP VAJ Z OZNAKO: H}

\section{Vaja H1}

Osebi AA in BB sta na začetku leta ustanovili družbo H1 d.o.o. s 15.000 EUR osnovnega kapitala. Oseba AA ima $20 \%$ poslovni delež v tej družbi, oseba BB pa $80 \%$ poslovni delež v tej družbi. Osebi AA in BB sta zagotovili celoten denarni vložek. Takoj ob ustanovitvi sta vplačali celotni denarni vložek na transakcijski račun novoustanovljene družbe.

V družbi H1 d.o.o. se tekom leta zgodi več poslovnih dogodkov. Družba ima na koncu poslovnega leta poslovni izid enak nič (torej nima niti dobička niti izgube).

Po koncu poslovnega leta vstopi v družbo nov družbenik oseba CC, ki ima nato v družbi H1 d.o.o. 50 \% delež. Družbeniki AA, BB in CC so se dogovorili, da je oseba CC vstopila $\mathrm{v}$ družbo $\mathrm{z}$ odprodajo dela deležev družbe H1 d.o.o. obstoječih družbenikov AA in BB novemu družbeniku CC. Med obstoječima družbenikoma $\mathrm{AA}$ in $\mathrm{BB}$ ostane sorazmerno enako razmerje $\mathrm{v}$ družbi. 
Naloga in vprašanja (žnavodili):

- Izdelajte poenostavljeno shemo bilance stanja družbe H1 d.o.o. na koncu leta pred dogodkom vstopa novega družbenika v družbo.

- Kolikšno je razmerje med družbenikoma v družbi?

- Izdelajte poenostavljeno shemo bilance stanja družbe H1 d.o.o. na koncu leta po dogodku vstopa novega družbenika v družbo.

- Kolikšen znesek mora plačati oseba CC pri dogodku vstopa v družbo? Komu?

- Kolikšno je razmerje med družbeniki v družbi?

- Katera sredstva (premoženje) in obveznosti (do virov sredstev) ima družba? Koliko?

- Kolikšna je knjigovodska vrednost kapitala družbe?

- Kolikšna je knjigovodska vrednost poslovnega deleža vsakega družbenika v družbi?

(Opomba: prikažite izračune in zapište odgovore.)

\section{Rešitev}

Bilanca stanja

\begin{tabular}{|c|c|c|c|c|}
\hline \multirow{5}{*}{$\begin{array}{r}\text { Denarna sredstva } \\
\text { (na TR) }\end{array}$} & SREDSTVA & OBV. DO & \multirow{2}{*}{$\begin{array}{l}\text { Osnovni kapital } \\
\text { (vpoklican) }\end{array}$} & \\
\hline & \multirow[t]{5}{*}{15.000} & \multirow[t]{4}{*}{15.000} & & \\
\hline & & & 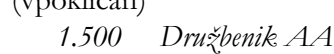 & 0,1000 \\
\hline & & & 6.000 Družbenik BB & 0,4000 \\
\hline & & & 7.500 Drušbenik CC & 0,5000 \\
\hline \multirow[b]{2}{*}{$\begin{array}{r}\text { SKUPAJ SRED. } \\
>>\end{array}$} & & 0 & \multirow{2}{*}{$\begin{array}{l}<\text { Posl. izid (iz IPI) } \\
<<\text { SKUPAJ OBV. }\end{array}$} & \\
\hline & 15.000 & 15.000 & & \\
\hline
\end{tabular}

\begin{tabular}{|c|c|}
\hline $\begin{array}{c}\text { Izračun } \\
\text { sprem. } \\
\text { posl. del.: }\end{array}$ & $\begin{array}{c}\text { [Potr. } \\
\text { plačilo] }\end{array}$ \\
\hline$-0,1000$ & -1.500 \\
\hline$-0,4000$ & -6.000 \\
\hline 0,5000 & \\
\hline 0 & -7.500 \\
\hline
\end{tabular}

Družbenik AA Družbenik BB Družbenik CC SKUPAJ

\begin{tabular}{|c|c|c|c|}
\hline $\begin{array}{c}\text { "Star" } \\
\text { OK } \\
\text { (vpok1.) }\end{array}$ & $\begin{array}{c}\text { Izračun } \\
\text { sprem. OK } \\
\text { (vpok.): }\end{array}$ & $\begin{array}{c}\text { Nov OK } \\
\text { (vpok1.) }\end{array}$ & $\begin{array}{c}\text { Preverba } \\
\text { ohr. } \\
\text { razmerja }\end{array}$ \\
\hline 3.000 & -1.500 & 1.500 & 0,2 \\
\hline 12.000 & -6.000 & 6.000 & 0,8 \\
\hline & 7.500 & 7.500 & \\
\hline 15.000 & 0 & 15.000 & \\
\hline
\end{tabular}




\section{Vaja $\mathrm{H} 2$}

Osebe AA, BB in CC so na začetku leta ustanovile družbo H2 d.o.o. z 20.000 EUR osnovnega kapitala. Oseba AA ima $40 \%$ poslovni delež v tej družbi, oseba BB 35 $\%$ in oseba CC $25 \%$ poslovni delež v tej družbi. Osebe AA, BB in CC so se dogovorile in zagotovile 8.000 EUR, 7.000 EUR in 5.000 EUR denarnega vložka. Osebe AA, BB in CC so takoj ob ustanovitvi tudi vplačale celotni denarni vložek na transakcijski račun novoustanovljene družbe.

V družbi H2 d.o.o. se tekom leta zgodi več poslovnih dogodkov. Družba ima na koncu poslovnega leta poslovni izid enak nič (torej nima niti dobička niti izgube).

Po koncu poslovnega leta vstopi v družbo nov družbenik oseba DD, ki ima nato v družbi H2 d.o.o. 40 \% delež. Družbeniki AA, BB, CC in DD so se dogovorili, da je oseba DD vstopila v družbo z odprodajo dela deležev družbe H2 d.o.o. obstoječih družbenikov AA, BB in CC novemu družbeniku DD. Med obstoječimi družbeniki $\mathrm{AA}, \mathrm{BB}$ in CC ostane sorazmerno enako razmerje $\mathrm{v}$ družbi.

\section{Naloga in vprašanja (z. navodili):}

- Izdelajte poenostavljeno shemo bilance stanja družbe H2 d.o.o. na koncu leta pred dogodkom vstopa novega družbenika v družbo.

- Kolikšno je razmerje med družbeniki v družbi?

- Izdelajte poenostavljeno shemo bilance stanja družbe H2 d.o.o. na koncu leta po dogodku vstopa novega družbenika v družbo.

- Kolikšen znesek mora plačati oseba DD pri dogodku vstopa v družbo? Komu?

- Kolikšno je razmerje med družbeniki v družbi?

- Katera sredstva (premoženje) in obveznosti (do virov sredstev) ima družba? Koliko?

- Kolikšna je knjigovodska vrednost kapitala družbe?

- Kolikšna je knjigovodska vrednost poslovnega deleža vsakega družbenika v družbi?

(Opomba: prikažite ižračune in zapišite odgovore.) 


\section{Rešitev}

Bilanca stanja

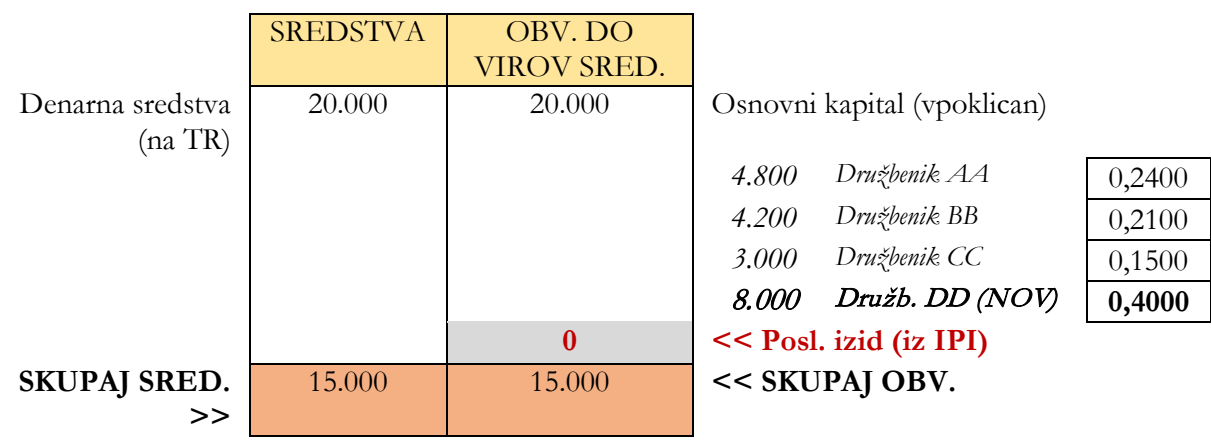

\begin{tabular}{|c|c|}
\hline $\begin{array}{c}\text { Izračun } \\
\text { sprem. } \\
\text { posl. del.: }\end{array}$ & $\begin{array}{c}\text { [Potr. } \\
\text { plačilo] }\end{array}$ \\
\hline$-0,1600$ & -3.200 \\
\hline$-0,1400$ & -2.800 \\
\hline$-0,1000$ & -2.000 \\
\hline 0,4000 & \\
\hline 0 & -8.000 \\
\hline
\end{tabular}

\begin{tabular}{|c|c|c|c|c|}
\cline { 2 - 5 } & $\begin{array}{c}\text { "Star" } \\
\text { OK } \\
\text { (vpok1.) }\end{array}$ & $\begin{array}{c}\text { Izračun } \\
\text { sprem. } \\
\text { OK } \\
\text { (vpok.): }\end{array}$ & $\begin{array}{c}\text { Nov OK } \\
\text { (vpokl.) }\end{array}$ & $\begin{array}{c}\text { Preverba } \\
\text { ohr. } \\
\text { razmerja }\end{array}$ \\
\cline { 2 - 5 } Družbenik AA & 8.000 & -3.200 & 4.800 & 0,4 \\
\cline { 2 - 5 } \begin{tabular}{c} 
Družbenik BB \\
Družbenik CC \\
Družbenik \\
\cline { 2 - 5 } $\begin{array}{c}\text { DD (NOV } \\
\text { SKUPAJ }\end{array}$
\end{tabular} & 5.000 & -2.800 & 4.200 & 0,35 \\
\cline { 2 - 5 } & 20.000 & -2.000 & 3.000 & 0,25 \\
\cline { 2 - 5 } & & 8.000 & 8.000 & \\
\hline
\end{tabular}

\section{Vaja $\mathrm{H3}$}

Osebe AA, BB, CC in DD so na začetku leta ustanovile družbo H3 d.o.o. z 20.000 EUR osnovnega kapitala. Oseba AA ima $50 \%$ poslovni delež v tej družbi, oseba BB $25 \%$, oseba CC $15 \%$ in oseba DD $10 \%$ poslovni delež v tej družbi. Osebe AA, $\mathrm{BB}, \mathrm{CC}$ in DD so se dogovorile in zagotovile 10.000 EUR, 5.000 EUR, 3.000 EUR in 2.000 EUR denarnega vložka. Osebe AA, BB, CC in DD so takoj ob ustanovitvi tudi vplačale celotni denarni vložek na transakcijski račun novoustanovljene družbe.

V družbi H3 d.o.o. se tekom leta zgodi več poslovnih dogodkov. Družba ima na koncu poslovnega leta poslovni izid enak nič (torej nima niti dobička niti izgube).

Po koncu poslovnega leta vstopi v družbo nov družbenik oseba EE, ki ima nato v družbi H3 d.o.o. 40 \% delež. Družbeniki AA, BB, CC, DD in EE so se dogovorili, 
da je oseba EE vstopila v družbo z odprodajo dela deležev družbe H3 d.o.o. obstoječih družbenikov AA, BB, CC in DD novemu družbeniku EE. Med obstoječimi družbeniki $\mathrm{AA}, \mathrm{BB}, \mathrm{CC}$ in $\mathrm{DD}$ ostane sorazmerno enako razmerje $\mathrm{v}$ družbi.

\section{Naloga in vprašanja (z navodili):}

- Izdelajte poenostavljeno shemo bilance stanja družbe H3 d.o.o. na koncu leta pred dogodkom vstopa novega družbenika v družbo.

- Kolikšno je razmerje med družbeniki v družbi?

- Izdelajte poenostavljeno shemo bilance stanja družbe H3 d.o.o. na koncu leta po dogodku vstopa novega družbenika $\mathrm{v}$ družbo.

- Kolikšen znesek mora plačati oseba EE pri dogodku vstopa v družbo? Komu?

- Kolikšno je razmerje med družbeniki v družbi?

- Katera sredstva (premoženje) in obveznosti (do virov sredstev) ima družba? Koliko?

- Kolikšna je knjigovodska vrednost kapitala družbe?

- Kolikšna je knjigovodska vrednost poslovnega deleža vsakega družbenika v družbi?

(Opomba: prikažite izračune in zapišite odgovore.)

\begin{tabular}{|c|c|c|c|c|c|}
\hline \multirow[b]{2}{*}{$\begin{array}{r}\text { Denarna sredstva } \\
\text { (na TR) }\end{array}$} & SREDSTVA & $\begin{array}{c}\text { OBV. DO } \\
\text { VIROV SRED. }\end{array}$ & \multirow{2}{*}{\multicolumn{2}{|c|}{ Osnovni kapital (vpoklican) }} & \\
\hline & \multirow[t]{7}{*}{20.000} & \multirow[t]{6}{*}{20.000} & & & \\
\hline \multirow[b]{7}{*}{$\begin{array}{r}\text { SKUPAJ } \\
\text { SREDSTVA >> }\end{array}$} & & & \multirow{5}{*}{\multicolumn{2}{|c|}{$\begin{array}{ll}6.000 & \text { Družbenik. AA } \\
3.000 & \text { Družbenik. BB } \\
1.800 & \text { Družbenik. CC } \\
1.200 & \text { Družbenik. DD } \\
\text { 8.000 } & \text { Družb. EE (NOV) }\end{array}$}} & 0,3000 \\
\hline & & & & & 0,1500 \\
\hline & & & & & 0,0900 \\
\hline & & & & & 0,0600 \\
\hline & & & & & 0,4000 \\
\hline & & 0 & \multirow{2}{*}{\multicolumn{3}{|c|}{$\begin{array}{l}<<\text { Posl. izid (iz IPI) } \\
<<\text { SKUPAJ OBVEZNOSTI }\end{array}$}} \\
\hline & 20.000 & 20.000 & & & \\
\hline
\end{tabular}




\begin{tabular}{|c|c|}
\hline $\begin{array}{c}\text { Izračun } \\
\text { sprem. } \\
\text { posl. del.: }\end{array}$ & $\begin{array}{c}\text { [Potr. } \\
\text { plačilo] }\end{array}$ \\
\hline$-0,2000$ & -4.000 \\
\hline$-0,1000$ & -2.000 \\
\hline$-0,0600$ & -1.200 \\
\hline$-0,0400$ & -800 \\
\hline 0,4000 & \\
\hline 0 & -8.000 \\
\hline
\end{tabular}

Družbenik AA

Družbenik BB

Družbenik CC

Družbenik DD

Družbenik EE

(NOV)

SKUPAJ

\begin{tabular}{|c|c|c|c|}
\hline $\begin{array}{c}\text { "Star" } \\
\text { OK } \\
\text { (vpokl.) }\end{array}$ & $\begin{array}{c}\text { Izračun } \\
\text { sprem. OK } \\
\text { (vpok.): }\end{array}$ & $\begin{array}{c}\text { Pov OK } \\
\text { (vpokl.) }\end{array}$ & $\begin{array}{c}\text { Preverba } \\
\text { ohr. } \\
\text { razmerja }\end{array}$ \\
\hline 10.000 & -4.000 & 6.000 & 0,5 \\
\hline 5.000 & -2.000 & 3.000 & 0,25 \\
\hline 3.000 & -1.200 & 1.800 & 0,15 \\
\hline 2.000 & -800 & 1.200 & 0,1 \\
\hline & 8.000 & 8.000 & \\
\hline 20.000 & 0 & 20.000 & \\
\hline
\end{tabular}

Vaja $\mathrm{H} 4$

Osebi AA in BB sta na začetku leta ustanovili družbo H4 d.o.o. s 16.000 EUR osnovnega kapitala. Oseba AA ima $75 \%$ poslovni delež v tej družbi, oseba BB pa $25 \%$ poslovni delež v tej družbi. Osebi AA in BB sta zagotovili celoten denarni vložek. Takoj ob ustanovitvi sta vplačali celotni denarni vložek na transakcijski račun novoustanovljene družbe.

V družbi H4 d.o.o. se zgodijo naslednji poslovni dogodki:

- Družba H4 d.o.o. na začetku leta izda obveznice v skupni vrednosti 5.000 EUR, ki jih uspešno proda. Prodane obveznice plača kupec banka BANKA d. d. takoj z nakazilom denarnih sredstev na transakcijski račun družbe $\mathrm{H} 4$ d.o.o. (Opomba: stroškov v zvezi z izdajo in prodajo obveznic ni.)

- Družba H4 d.o.o. pred koncem leta obračuna (kuponske) obresti iz naslova izdane obveznice $\mathrm{v}$ skupni vrednosti 1.000 EUR. Obresti je nakazala na transakcijski račun banke BANKA d.d. (Opomba: stroškov in davščin v zvezi z nakazilom obresti ni.)

- Družba H4 d.o.o. je opravila storitev pravnega svetovanja (na področju korporacijskega prava in davčnega prava) v vrednosti 14.000 EUR za naročnika fizično osebo DD. Oseba DD je opravljeno storitev poplačala takoj z nakazilom na transakcijski račun družbe $\mathrm{H} 4$ d.o.o. Storitev pravnega svetovanja je bila t. i. intelektualna storitev. (Opomba: davščin - npr. davka na dodano vrednost $-\mathrm{v}$ zvezi s prodajo storitve ni.)

- Družba H4 d.o.o. je zaradi opravljanja naročene storitve prepoznala potrebo po raznovrstnem pisarniškem materialu (redniki, mape, papir, pisala itd.). Vse to je družba v skupni vrednosti 2.000 EUR kupila pri različnih dobaviteljih, katerim 
je družba poplačala takoj ob nakupu z gotovino. Ves pisarniški material je družba porabila pri opravljanju naročene storitve.

- Družba H4 d.o.o. je obračunala delo, ki ga je opravila pri njej zaposlena oseba EE v času izvajanja storitve. Skupna vrednost obračunanega dela je 12.000 EUR. Družba H4 d.o.o. je v zvezi z obračunanim delom izvedla nakazili s svojega transakcijskega računa osebi EE in v državni proračun.

- Po koncu poslovnega leta vstopi v družbo nov družbenik oseba CC, ki ima nato v družbi H4 d.o.o. 50 \% delež. Družbeniki AA, BB in CC so se dogovorili, da je oseba CC vstopila v družbo z odprodajo dela deležev družbe H4 d.o.o. obstoječih družbenikov AA in BB novemu družbeniku CC. Med obstoječima družbenikoma $\mathrm{AA}$ in $\mathrm{BB}$ ostane sorazmerno enako razmerje $\mathrm{v}$ družbi.

\section{Naloga in vprašanja (z navodili):}

- Izdelajte poenostavljeno shemo bilance stanja družbe H4 d.o.o. na začetku leta.

- Izdelajte poenostavljeno shemo izkaza poslovnega izida družbe H4 d.o.o. za poslovno leto. (Opomba: davka na dobiček - natančneje: davka od dohodka pravnih oseb - ni.)

- Če ima, katere prihodke in/ali odhodke ima družba? Koliko?

- Kateri je poslovni izid? Kolikšen?

- Izdelajte poenostavljeno shemo bilance stanja družbe H4 d.o.o. na koncu leta pred dogodkom vstopa novega družbenika v družbo.

- Katera sredstva (premoženje) in obveznosti (do virov sredstev) ima družba? Koliko?

- Kolikšna je knjigovodska vrednost kapitala družbe?

- Če bi družbo likvidirali, kolikšen bi bil obseg sredstev (premoženja), razpoložljivih(ega) upnikom družbe?

- Kolikšna je knjigovodska, likvidacijska in tržna vrednost poslovnega deleža vsakega družbenika v družbi?

- Izdelajte poenostavljeno shemo bilance stanja družbe H4 d.o.o. na koncu leta po dogodku vstopa novega družbenika $\mathrm{v}$ družbo.

- Kolikšen znesek mora plačati oseba CC pri dogodku vstopa v družbo? Komu?

- Katera sredstva (premoženje) in obveznosti (do virov sredstev) ima družba? Koliko?

- Kolikšna je knjigovodska vrednost kapitala družbe? 
- Če bi družbo likvidirali, kolikšen bi bil obseg sredstev (premoženja), razpoložljivih(ega) upnikom družbe?

- Kolikšna je knjigovodska, likvidacijska in tržna vrednost poslovnega deleža vsakega družbenika v družbi?

(Opomba: prikažite iæračune in zapisite odgovore.)

\section{Rešitev}

Izkaz poslovnega izida

\begin{tabular}{|c|c|c|c|}
\hline \multirow{3}{*}{$\begin{array}{r}\text { Stroški porabljenega } \\
\text { materiala } \\
\text { Stroški dela }\end{array}$} & ODHODKI & PRIHODKI & \multirow{4}{*}{ Prihodki od prodaje storitev } \\
\hline & 2.000 & \multirow[t]{3}{*}{14.000} & \\
\hline & 12.000 & & \\
\hline Odhodki (str. finan.) & 1.000 & & \\
\hline Dobiček >> & & 1.000 & \multirow{2}{*}{$\begin{array}{l}<<\text { Izguba } \\
<<\text { SKUPAJ PAS. STRAN }\end{array}$} \\
\hline $\begin{array}{l}\text { SKUPAJ AKT. } \\
\text { STRAN >> }\end{array}$ & 15.000 & 15000 & \\
\hline
\end{tabular}

Bilanca stanja

\begin{tabular}{|c|c|c|c|c|}
\hline \multirow{7}{*}{$\begin{array}{r}\text { Denarna sredstva } \\
\text { (na TR) }\end{array}$} & SREDSTVA & $\begin{array}{c}\text { OBV. DO } \\
\text { VIROV SRED. }\end{array}$ & \multirow{2}{*}{\multicolumn{2}{|c|}{ Osnovni kapital (vpoklican) }} \\
\hline & \multirow[t]{6}{*}{20.000} & \multirow[t]{4}{*}{16.000} & & \\
\hline & & & \multirow{3}{*}{$\begin{array}{l}\text { 6.000 Družbenik. } A A \\
\text { 2.000 Družebnik } B B \\
\text { 8.000 Družbenik } C C\end{array}$} & 0,3750 \\
\hline & & & & 0,1250 \\
\hline & & & & 0,5000 \\
\hline & & -1.000 & \multirow{3}{*}{\multicolumn{2}{|c|}{$\begin{array}{l}<<\text { Posl. izid (izguba iz IPI) } \\
\text { Izdane obveznice (dolžniško } \\
\text { financiranje) } \\
<<\text { SKUPAJ OBVEZNOSTI }\end{array}$}} \\
\hline & & 5.000 & & \\
\hline KUUPAJ SRED. >> & 20.000 & 20.000 & & \\
\hline
\end{tabular}

\begin{tabular}{|c|c|}
\hline $\begin{array}{c}\text { Izračun } \\
\text { sprem. } \\
\text { posl. del.: }\end{array}$ & $\begin{array}{c}\text { [Potr. } \\
\text { plačilo] }\end{array}$ \\
\hline$-0,3750$ & -5.625 \\
\hline$-0,1250$ & -1.875 \\
\hline 0,5000 & \\
\hline 0 & -7.500 \\
\hline
\end{tabular}

Družbenik AA

Družbenik BB

Družbenik CC

SKUPAJ

\begin{tabular}{|c|c|c|}
\hline $\begin{array}{c}\text { "Star" } \\
\text { OK } \\
\text { (vpok1.) }\end{array}$ & $\begin{array}{c}\text { Izračun } \\
\text { sprem. OK } \\
\text { (vpok.): }\end{array}$ & $\begin{array}{c}\text { Nov OK } \\
\text { (vpok1.) }\end{array}$ \\
\hline 12.000 & -6.000 & 6.000 \\
\hline 4.000 & -2.000 & 2.000 \\
\hline & 8.000 & 8.000 \\
\hline 16.000 & 0 & 16.000 \\
\hline
\end{tabular}




\section{Vaja H5}

Osebe AA, BB in CC so na začetku leta ustanovile družbo H5 d.o.o. z 20.000 EUR osnovnega kapitala. Oseba AA ima $60 \%$ poslovni delež v tej družbi, oseba BB 25 $\%$ in oseba CC $15 \%$ poslovni delež v tej družbi. Osebe AA, BB in CC so se dogovorile in zagotovile 13.200 EUR, 5.500 EUR in 3.300 EUR denarnega vložka. Osebe AA, BB in CC so takoj ob ustanovitvi tudi vplačale celotni denarni vložek na transakcijski račun novoustanovljene družbe.

V družbi H5 d.o.o. se tekom leta zgodijo naslednji poslovni dogodki:

- Družba H5 d.o.o. je zaradi načrtovanega opravljanja storitev pravnega svetovanja potrebovala več računalniških in drugih pripomočkov (računalnik, tiskalnik, kopirni stroj itd.). Takoj na začetku leta je družba pripomočke v vrednosti 12.000 EUR kupila pri dobavitelju družbi PP d.o.o., kateri je poplačala takoj z nakazilom denarnih sredstev s svojega transakcijskega računa. (Opomba: davščin - npr. davka na dodano vrednost - v zvezi z nakupom pripomočkov ni.)

- Družba H5 d.o.o. je pripomočke uporabljala celo leto, zaradi česar je obračunala t. i. amortizacijo zanje v vrednosti 6.000 EUR. (Opomba: družba uporablja metodo enakomernega časovnega amortiziranja. Letna amortizacijska stopnja za računalniške pripomočke je $50 \%$.)

- Poslovodstvo družbe H5 d.o.o. je ocenilo, da potrebuje dodatna denarna sredstva za svoje poslovanje. Družba je zato takoj po ustanovitvi najela 10.000 EUR posojila pri (nepovezani) družbi POSOJA d.o.o. Posojilodajalec tudi nakaže posojilo družbi na njen transakcijski račun. (Opomba: stroškov najema posojila ni.)

- Družba H5 d.o.o. pred koncem leta prejme obračun obresti iz naslova najetega posojila v skupni vrednosti 1.000 EUR. Obresti je nakazala na transakcijski račun družbe POSOJA d.o.o. (Opomba: stroškov in davščin v zvezi z nakazilom obresti ni.)

- Družba H5 d.o.o. je opravila storitev pravnega svetovanja (na področju korporacijskega prava in davčnega prava) v vrednosti 33.000 EUR za naročnika fizično osebo EE. Oseba EE je opravljeno storitev poplačala takoj z nakazilom na transakcijski račun družbe H5 d.o.o. Storitev pravnega svetovanja je bila t. i. intelektualna storitev. (Opomba: davščin - npr. davka na dodano vrednost - v zvezi s prodajo storitve ni.) 
- Družba H5 d.o.o. je obračunala delo, ki ga je opravila pri njej zaposlena oseba FF v času izvajanja storitve. Skupna vrednost obračunanega dela je 18.000 EUR. Družba H5 d.o.o. je v zvezi z obračunanim delom izvedla nakazili s svojega transakcijskega računa osebi FF in $\mathrm{v}$ državni proračun.

- Po koncu poslovnega leta vstopi v družbo nov družbenik oseba DD, ki ima nato v družbi H5 d.o.o. 15 \% delež. Družbeniki AA, BB, CC in DD so se dogovorili, da je oseba DD vstopila v družbo z odprodajo dela deležev družbe H5 d.o.o. obstoječih družbenikov $\mathrm{AA}, \mathrm{BB}$ in $\mathrm{CC}$ novemu družbeniku DD. Med obstoječimi družbeniki $\mathrm{AA}, \mathrm{BB}$ in $\mathrm{CC}$ ostane sorazmerno enako razmerje $\mathrm{v}$ družbi.

\section{Naloga in vprašanja (z.navodili):}

- Izdelajte poenostavljeno shemo bilance stanja družbe H5 d.o.o. na začetku leta.

- Izdelajte poenostavljeno shemo izkaza poslovnega izida družbe H5 d.o.o. za poslovno leto. (Opomba: davka na dobiček - natančneje: davka od dohodka pravnih oseb - ni.)

- Če ima, katere prihodke in/ali odhodke ima družba? Koliko?

- Kateri je poslovni izid? Kolikšen?

- Izdelajte poenostavljeno shemo bilance stanja družbe H5 d.o.o. na koncu leta pred dogodkom vstopa novega družbenika v družbo.

- Katera sredstva (premoženje) in obveznosti (do virov sredstev) ima družba? Koliko?

- Kolikšna je knjigovodska vrednost kapitala družbe?

- Če bi družbo likvidirali, kolikšen bi bil obseg sredstev (premoženja), razpoložljivih(ega) upnikom družbe?

- Kolikšna je knjigovodska, likvidacijska in tržna vrednost poslovnega deleža vsakega družbenika v družbi?

- Izdelajte poenostavljeno shemo bilance stanja družbe H5 d.o.o. na koncu leta po dogodku vstopa novega družbenika v družbo.

- Kolikšen znesek mora plačati oseba DD pri dogodku vstopa v družbo? Komu?

- Katera sredstva (premoženje) in obveznosti (do virov sredstev) ima družba? Koliko?

- Kolikšna je knjigovodska vrednost kapitala družbe?

- Če bi družbo likvidirali, kolikšen bi bil obseg sredstev (premoženja), razpoložljivih(ega) upnikom družbe? 
- Kolikšna je knjigovodska, likvidacijska in tržna vrednost poslovnega deleža vsakega družbenika v družbi?

(Opomba: prikažite iz̧ačune in zapišite odgovore.)

\section{Rešitev}

Izkaz poslovnega izida

\begin{tabular}{|c|c|c|c|}
\hline \multirow{4}{*}{$\begin{array}{r}\text { Stroški amortizacije } \\
\text { Stroški dela } \\
\text { Odhodki (str. finan.) } \\
\text { Dobiček }>>\end{array}$} & ODHODKI & PRIHODKI & \multirow{4}{*}{ Prihodki od prodaje storitev } \\
\hline & $\begin{array}{c}6.000 \\
18000\end{array}$ & 33.000 & \\
\hline & 1.000 & & \\
\hline & 8.000 & & \\
\hline $\begin{array}{r}\text { SKUPAJ AKT. } \\
\text { STRAN >> }\end{array}$ & 33.000 & 33.000 & $<<$ SKUPAJ PAS. STRAN \\
\hline
\end{tabular}

Bilanca stanja

\begin{tabular}{|c|c|c|c|c|c|}
\hline \multirow{3}{*}{$\begin{array}{r}\text { Osnovna sredstva } \\
\text { (oprema) } \\
\text { Denarna sredstva } \\
\text { (na TR) }\end{array}$} & \multirow{2}{*}{$\begin{array}{c}\text { SREDSTVA } \\
6.000\end{array}$} & \multirow{2}{*}{$\begin{array}{c}\text { OBV. DO } \\
\text { VIROV SRED. } \\
20.000\end{array}$} & \multirow{2}{*}{\multicolumn{3}{|c|}{ Osnovni kapital (vpoklican) }} \\
\hline & & & & & \\
\hline & 34.000 & & 10.200 & Družbenik. $A A$ & 0,5100 \\
\hline & & & 4.250 & Drǔbenik $B B$ & 0,2125 \\
\hline & & & 2.550 & Družbenik CC & 0,1275 \\
\hline & & & 3.000 & $\begin{array}{l}\text { Družb. DD } \\
\text { (NOV) }\end{array}$ & 0,1500 \\
\hline & & 2.000 & Kapital & rezerve & \\
\hline & & 8.000 & $<<\mathrm{Po}$ & izid (dobiček & iz IPI) \\
\hline & & 10.000 & $\begin{array}{l}\text { Obv. z } \\
\text { (dolžni }\end{array}$ & $\begin{array}{l}\text { ajeto posojilo } \\
\text { o finan.) }\end{array}$ & \\
\hline KUPAJ SRED. >> & 40.000 & 40.000 & $<<$ SK & PAJ OBV. & \\
\hline
\end{tabular}

\begin{tabular}{|c|c|}
\hline $\begin{array}{c}\text { Izračun } \\
\text { sprem. } \\
\text { posl. del.: }\end{array}$ & $\begin{array}{c}\text { [Potr. } \\
\text { plačilo] }\end{array}$ \\
\hline$-0,0900$ & -2.700 \\
\hline$-0,0375$ & -1.125 \\
\hline$-0,0225$ & -675 \\
\hline 0,1500 & \\
\hline 0 & -4.500 \\
\hline
\end{tabular}

Družbenik AA

Družbenik BB

Družbenik CC

Družb. DD (NOV)

SKUPAJ

\begin{tabular}{|c|c|c|}
\hline $\begin{array}{c}\text { "Star" } \\
\text { OK } \\
\text { (vpok1.) }\end{array}$ & $\begin{array}{c}\text { Izračun } \\
\text { sprem. OK } \\
\text { (vpok.): }\end{array}$ & $\begin{array}{c}\text { Nov OK } \\
\text { (vpokl.) }\end{array}$ \\
\hline 12.000 & -1.800 & 10.200 \\
\hline 5.000 & -750 & 4.250 \\
\hline 3.000 & -450 & 2.550 \\
\hline & 3.000 & 3.000 \\
\hline 20.000 & 0 & 20.000 \\
\hline
\end{tabular}




\section{Vaja H6}

Osebe AA, BB in CC so na začetku leta ustanovile družbo H6 d.o.o. s 15.000 EUR osnovnega kapitala. Oseba AA ima $40 \%$ poslovni delež v tej družbi, oseba BB 35 $\%$ in oseba CC $25 \%$ poslovni delež v tej družbi. Oseba AA je zagotovila poslovni prostor kot stvarni vložek v višini 6.000 EUR, osebi BB in CC pa sta zagotovili 5.250 EUR in 3.750 EUR denarnega vložka. Osebi BB in CC sta takoj ob ustanovitvi tudi vplačali celotni denarni vložek na transakcijski račun novoustanovljene družbe.

V družbi H6 d.o.o. se tekom leta zgodijo naslednji poslovni dogodki:

- Družba H6 d.o.o. je načrtovala začetek proizvodnje izdelka (v količini 10.000 kosov). Za izdelavo takšne količine izdelkov je potreben raznovrsten material. Ves potreben material je družba v skupni vrednosti 10.000 EUR kupila pri različnih dobaviteljih, katerim je družba poplačala takoj ob nakupu z nakazilom s svojega transakcijskega računa.

- Družba H6 d.o.o. je pri proizvodnji izdelkov ves material porabila. Družba vrednoti svoje zaloge proizvedenih izdelkov po polni stroškovni ceni. ${ }^{30}$ (Opomba: na začetku leta in na koncu leta ni nobenih zalog materiala.)

- Družba H6 d.o.o. je za opravilo proizvodnje izdelkov naročila več storitev opravljanja raznovrstnih del pri več izkušenih proizvajalcih podobnih izdelkov (kot podizvajalcih) v skupni vrednosti 12.000 EUR. Družba H6 d.o.o. je kupljene storitve izkušenih proizvajalcev plačala takoj z nakazili s svojega transakcijskega računa. (Opomba: davščin - npr. davka na dodano vrednost - v zvezi z nakupom storitev ni.)

- Družba H6 d.o.o. je na koncu leta prodala celotno zalogo proizvedenih izdelkov kupcu MAKSI d.o.o. Kupec je poplačal kupljene proizvedene izdelke v vrednosti 25.000 EUR takoj z nakazilom na transakcijski račun družbe H6 d.o.o. (Opomba: davščin - npr. davka na dodano vrednost - v zvezi s prodajo proizvedenih izdelkov ni.)

- Družba H6 d.o.o. je na začetku leta kupila delnice druge družbe ZZ d.d. v skupni vrednosti 15.000 EUR. Kupljene delnice je plačala takoj z nakazilom denarnih sredstev s transakcijskega računa družbe prodajalcu delnic. (Opomba: stroškov $\mathrm{v}$ zvezi s prenosom delnic ni.)

\footnotetext{
${ }^{30}$ Obstaja več različnih metod vrednotenja zalog proizvodov oz. učinkov v podjetju. Podrobneje o tem glejte opombo 1.
} 
- Družba H6 d.o.o. je pred koncem leta prejela dividende od družbe ZZ d.d. v skupni vrednosti 2.000 EUR. Nakazilo je bilo izvršeno na transakcijski račun družbe H6 d.o.o. (Opomba: davščin v zvezi z nakazilom dividend oz. potrebe po akontaciji davščin ni.)

- Po koncu poslovnega leta vstopi v družbo nov družbenik oseba DD, ki ima nato v družbi H6 d.o.o. 80 \% delež. Družbeniki AA, BB, CC in DD so se dogovorili, da je oseba DD vstopila v družbo z odprodajo dela deležev družbe H6 d.o.o. obstoječih družbenikov $\mathrm{AA}, \mathrm{BB}$ in $\mathrm{CC}$ novemu družbeniku DD. Med obstoječimi družbeniki $\mathrm{AA}, \mathrm{BB}$ in $\mathrm{CC}$ ostane sorazmerno enako razmerje $\mathrm{v}$ družbi.

Naloga in uprašanja (z navodili):

- Izdelajte poenostavljeno shemo bilance stanja družbe H6 d.o.o. na začetku leta.

- Izdelajte poenostavljeno shemo izkaza poslovnega izida družbe H6 d.o.o. za poslovno leto. (Opomba: davka na dobiček - natančneje: davka od dohodka pravnih oseb - ni.)

- Če ima, katere prihodke in/ali odhodke ima družba? Koliko?

- Kateri je poslovni izid? Kolikšen?

- Izdelajte poenostavljeno shemo bilance stanja družbe H6 d.o.o. na koncu leta pred dogodkom vstopa novega družbenika v družbo.

- Katera sredstva (premoženje) in obveznosti (do virov sredstev) ima družba? Koliko?

- Kolikšna je knjigovodska vrednost kapitala družbe?

- Če bi družbo likvidirali, kolikšen bi bil obseg sredstev (premoženja), razpoložljivih(ega) upnikom družbe?

- Kolikšna je knjigovodska, likvidacijska in tržna vrednost poslovnega deleža vsakega družbenika $v$ družbi?

- Izdelajte poenostavljeno shemo bilance stanja družbe H6 d.o.o. na koncu leta po dogodku vstopa novega družbenika v družbo.

- Kolikšen znesek mora plačati oseba DD pri dogodku vstopa v družbo? Komu?

- Katera sredstva (premoženje) in obveznosti (do virov sredstev) ima družba? Koliko?

- Kolikšna je knjigovodska vrednost kapitala družbe? 
- Če bi družbo likvidirali, kolikšen bi bil obseg sredstev (premoženja), razpoložljivih(ega) upnikom družbe?

- Kolikšna je knjigovodska, likvidacijska in tržna vrednost poslovnega deleža vsakega družbenika v družbi?

(Opomba: prikažite izračune in zapisite odgovore.)

\section{Rešitev}

Izkaz poslovnega izida

\begin{tabular}{|c|c|c|c|}
\hline \multirow{4}{*}{$\begin{array}{r}\text { Odhodki (stroškovna } \\
\text { vrednost prod. } \\
\text { proiz.): }\end{array}$} & ODHODKI & PRIHODKI & \multirow{4}{*}{$\begin{array}{l}\text { Prihodki od prodaje proizvodov } \\
\text { Finančni prihodki (od prejetih } \\
\text { dividend) }\end{array}$} \\
\hline & \multirow[b]{4}{*}{10.000} & \multirow{7}{*}{$\begin{array}{l}25.000 \\
2.000\end{array}$} & \\
\hline & & & \\
\hline & & & \\
\hline Odhodki (stroški & & & \multirow{6}{*}{$\begin{array}{l}<<\text { Izguba } \\
<<\text { SKUPAJ PAS. STRAN }\end{array}$} \\
\hline porabljenega material) & \multirow{3}{*}{12.000} & & \\
\hline Odhodki (stroški & & & \\
\hline kupljene storitve) & & & \\
\hline Dobiček >> & 5.000 & & \\
\hline $\begin{array}{r}\text { SKUPAJ AKT. } \\
\text { STRAN >> }\end{array}$ & 27.000 & 27.000 & \\
\hline
\end{tabular}

Bilanca stanja

\begin{tabular}{|c|c|c|c|c|c|}
\hline \multirow{3}{*}{$\begin{array}{r}\text { Finančna naložba } \\
\text { (kupljene delnice) } \\
\text { Denarna sredstva } \\
\text { (na TR) }\end{array}$} & \multirow[t]{2}{*}{$\begin{array}{c}\text { SREDSTVA } \\
15.000\end{array}$} & \multirow[t]{2}{*}{$\begin{array}{c}\text { OBV. DO } \\
\text { VIROV SRED. } \\
15.000\end{array}$} & \multirow{2}{*}{\multicolumn{3}{|c|}{ Osnovni kapital (vpoklican) }} \\
\hline & & & & & \\
\hline & \multirow[t]{5}{*}{5.000} & & 1.200 & Družbenik. $A A$ & 0,0800 \\
\hline \multirow[b]{5}{*}{ JPAJ SRED. >> } & & & 1.050 & Drušbenik BB & 0,0700 \\
\hline & & & 750 & Družbenik CC & 0,0500 \\
\hline & & & 12.000 & $\begin{array}{l}\text { Družb. DD } \\
\text { (NOV) }\end{array}$ & 0,8000 \\
\hline & & 5.000 & \multirow{2}{*}{\multicolumn{3}{|c|}{$\begin{array}{l}<<\text { Posl. izid (dobiček iz IPI) } \\
<<\text { SKUPAI OBV. }\end{array}$}} \\
\hline & 20.000 & 20.000 & & & \\
\hline
\end{tabular}

\begin{tabular}{|c|c|}
\hline $\begin{array}{c}\text { Izračun } \\
\text { sprem. } \\
\text { posl. del.: }\end{array}$ & $\begin{array}{c}\text { [Potr. } \\
\text { plačilo] }\end{array}$ \\
\hline$-0,3200$ & -6.400 \\
\hline$-0,2800$ & -5.600 \\
\hline$-0,2000$ & -4.000 \\
\hline 0,8000 & \\
\hline 0 & -16.000 \\
\hline
\end{tabular}

Družbenik A

Družbenik B

Družbenik C

Družb. D (NOV)

SKUPAJ

\begin{tabular}{|c|c|c|}
\hline $\begin{array}{c}\text { "Star" } \\
\text { OK } \\
\text { (vpokl.) }\end{array}$ & $\begin{array}{c}\text { Izračun } \\
\text { sprem. OK } \\
\text { (vpok.): }\end{array}$ & $\begin{array}{c}\text { Nov OK } \\
\text { (vpokl.) }\end{array}$ \\
\hline 6.000 & -4.800 & 1.200 \\
\hline 5.250 & -4.200 & 1.050 \\
\hline 3.750 & -3.000 & 750 \\
\hline & 12.000 & 12.000 \\
\hline 15.000 & 0 & 15.000 \\
\hline
\end{tabular}




\section{Vaja $\mathrm{H} 7$}

Osebe AA, BB, CC in DD so na začetku leta ustanovile družbo H7 d.o.o. z 20.000 EUR osnovnega kapitala. Oseba AA ima $40 \%$ poslovni delež v tej družbi, oseba BB $30 \%$, oseba CC $20 \%$ in oseba DD $10 \%$ poslovni delež v tej družbi. Oseba AA je zagotovila poslovni prostor kot stvarni vložek v višini 8.000 EUR ter dodatno 800 EUR denarnega vložka, osebe BB, CC in DD pa so zagotovile 6.600 EUR, 4.400 EUR in 2.200 EUR denarnega vložka. Osebe AA, BB, CC in DD so takoj ob ustanovitvi tudi vplačale celotni denarni vložek na transakcijski račun novoustanovljene družbe.

V družbi H7 d.o.o. se tekom leta zgodijo naslednji poslovni dogodki:

- Družba H7 d.o.o. je načrtovala začetek proizvodnje izdelka (v količini 8.000 kosov). Za izdelavo takšne količine izdelkov je potreben raznovrsten material. Ves potreben material je družba $\mathrm{v}$ skupni vrednosti 12.000 EUR kupila pri različnih dobaviteljih, katerim je družba poplačala takoj ob nakupu z nakazilom s svojega transakcijskega računa.

- Družba H7 d.o.o. je zaradi načrtovane proizvodnje potrebovala poseben stroj/napravo. Takoj na začetku leta je družba stroj/napravo v vrednosti 10.000 EUR kupila pri dobavitelju družbi MM d.o.o., kateri je poplačala takoj z nakazilom denarnih sredstev s svojega transakcijskega računa. (Opomba: davščin - npr. davka na dodano vrednost - v zvezi z nakupom stroja/naprave ni.)

- Družba H7 d.o.o. je poslovni prostor in stroj/napravo uporabljala celo leto, zaradi česar je obračunala t. i. amortizacijo zanj(o) v skupni vrednosti 4.000 EUR. (Opomba: družba uporablja metodo enakomernega časovnega amortiziranja. Letna amortizacijska stopnja za poslovni prostor je $25 \%$. Letna amortizacijska stopnja za stroj/napravo je $20 \%$.)

- Družba H7 d.o.o. je pri proizvodnji izdelkov ves material porabila. Družba vrednoti svoje zaloge proizvedenih izdelkov po polni stroškovni ceni. ${ }^{31}$ (Opomba: na začetku leta in na koncu leta ni nobenih zalog materiala.)

- Družba H7 d.o.o. je prodala celotno zalogo proizvedenega izdelka kupcu MAKSI d.o.o. Kupec je poplačal opravljen nakup v vrednosti 23.000 EUR takoj

\footnotetext{
31 Obstaja več različnih metod vrednotenja zalog proizvodov oz. učinkov v podjetju. Podrobneje o tem glejte opombo 1.
} 
z nakazilom na transakcijski račun družbe H7 d.o.o. (Opomba: davščin - npr. davka na dodano vrednost $-\mathrm{v}$ zvezi s prodajo proizvedenega izdelka ni.)

- Družba H7 d.o.o. je obračunala delo, ki ga je opravila pri njej zaposlena oseba FF v času proizvodnje izdelka (v količini 8.000 kosov). Skupna vrednost obračunanega dela je 5.000 EUR. (Opomba: družba vrednoti svoje zaloge izdelkov po polni stroškovini ceni.) Družba H7 d.o.o. je v zvezi z obračunanim delom izvedla nakazili s svojega transakcijskega računa osebi FF in v državni proračun.

- Poslovodstvo družbe H7 d.o.o. je takoj po ustanovitvi odobrilo posojilo v višini 10.000 EUR (nepovezani) družbi KARTA d.o.o. Družba kot posojilodajalec je tudi nakazala posojilo družbi posojilojemalki na njen transakcijski račun. (Opomba: stroškov v zvezi z odobritvijo in nakazilom posojila ni.)

- Družba H7 d.o.o. pred koncem leta obračuna obresti iz naslova danega posojila v skupni vrednosti 1.000 EUR. Obresti je prejela nakazane na svoj transakcijski račun s strani posojilojemalke družbe KARTA d.o.o. (Opomba: stroškov in davščin v zvezi s prejemom nakazila obresti ni.)

- Po koncu poslovnega leta vstopi v družbo nov družbenik oseba EE, ki ima nato v družbi $\mathrm{H7}$ d.o.o. 50 \% delež. Družbeniki AA, BB, CC, DD in EE so se dogovorili, da je oseba EE vstopila v družbo z odprodajo dela deležev družbe $\mathrm{H} 7$ d.o.o. obstoječih družbenikov $\mathrm{AA}, \mathrm{BB}, \mathrm{CC}$ in DD novemu družbeniku EE. Med obstoječimi družbeniki AA, BB, CC in DD ostane sorazmerno enako razmerje $\mathrm{v}$ družbi.

\section{Naloga in uprašanja (z navodili):}

- Izdelajte poenostavljeno shemo bilance stanja družbe H7 d.o.o. na začetku leta.

- Izdelajte poenostavljeno shemo izkaza poslovnega izida družbe H7 d.o.o. za poslovno leto. (Opomba: davka na dobiček - natančneje: davka od dohodka pravnih oseb - ni.)

- Če ima, katere prihodke in/ali odhodke ima družba? Koliko?

- Kateri je poslovni izid? Kolikšen?

- Izdelajte poenostavljeno shemo bilance stanja družbe H7 d.o.o. na koncu leta pred dogodkom vstopa novega družbenika v družbo.

- Katera sredstva (premoženje) in obveznosti (do virov sredstev) ima družba? Koliko?

- Kolikšna je knjigovodska vrednost kapitala družbe?

- Če bi družbo likvidirali, kolikšen bi bil obseg sredstev (premoženja), razpoložljivih(ega) upnikom družbe? 
- Kolikšna je knjigovodska, likvidacijska in tržna vrednost poslovnega deleža vsakega družbenika v družbi?

- Izdelajte poenostavljeno shemo bilance stanja družbe H7 d.o.o. na koncu leta po dogodku vstopa novega družbenika v družbo.

- Kolikšen znesek mora plačati oseba EE pri dogodku vstopa v družbo? Komu?

- Katera sredstva (premoženje) in obveznosti (do virov sredstev) ima družba? Koliko?

- Kolikšna je knjigovodska vrednost kapitala družbe?

- Če bi družbo likvidirali, kolikšen bi bil obseg sredstev (premoženja), razpoložljivih(ega) upnikom družbe?

- Kolikšna je knjigovodska, likvidacijska in tržna vrednost poslovnega deleža vsakega družbenika v družbi?

(Opomba: prikažite iquačune in zapisite odgovore.) 


\section{Rešitev}

Izkaz poslovnega izida

\begin{tabular}{|c|c|c|c|}
\hline \multirow{5}{*}{$\begin{array}{r}\text { Odhodki (stroškovna } \\
\text { vrednost prod. proiz.): } \\
\text { Odhodki (stroški } \\
\text { porabljenega materiala) } \\
\text { Odhodki (stroški dela) } \\
\text { Stroški amoortiqacije }\end{array}$} & ODHODKI & PRIHODKI & \multirow[b]{2}{*}{$\begin{array}{l}\text { Prihodki od prodaje proizvodov } \\
\text { Finančni prihodki (od prejetih } \\
\text { obresti) }\end{array}$} \\
\hline & & $\begin{array}{c}23.000 \\
1.000\end{array}$ & \\
\hline & 12.000 & & \\
\hline & 5.000 & & \\
\hline & 4.000 & & \\
\hline Dobiček >> & 3.000 & & $<<$ Izguba \\
\hline $\begin{array}{l}\text { SKUPAJ AKT. } \\
\text { STRAN >> }\end{array}$ & 24.000 & 24.000 & $<<$ SKUPAJ PAS. STRAN \\
\hline
\end{tabular}

Bilanca stanja

\begin{tabular}{|c|c|c|c|c|c|}
\hline \multirow{3}{*}{$\begin{array}{r}\text { Osnovna sredstva } \\
\text { (posl. prostor, oprema) } \\
\text { Finančna naložba } \\
\text { (dano posojilo) }\end{array}$} & \multirow{2}{*}{$\begin{array}{c}\text { SREDSTVA } \\
14.000\end{array}$} & \multirow{2}{*}{$\begin{array}{c}\text { OBV. DO } \\
\text { VIROV SRED. } \\
10.000\end{array}$} & \multirow{2}{*}{\multicolumn{3}{|c|}{ Osnovni kapital (vpoklican) }} \\
\hline & & & & & \\
\hline & 10.000 & & 4.000 & Družbenik. $A A$ & 0,2000 \\
\hline \multirow[t]{6}{*}{$\begin{array}{r}\text { Denarna sredstva (na } \\
\text { TR) }\end{array}$} & 1.000 & & 3.000 & Družbenik. BB & 0,1500 \\
\hline & & & 2.000 & Družbenik. CC & 0,1000 \\
\hline & & & 1.000 & Družbenik DD & 0,0500 \\
\hline & & & 10.000 & $\begin{array}{l}\text { Družb. EE } \\
\text { (NOV) }\end{array}$ & 0,5000 \\
\hline & & 2.000 & \multirow{3}{*}{\multicolumn{3}{|c|}{$\begin{array}{l}\text { Kapitalske rezerve } \\
<<\text { Posl. izid (dobiček iz IPI) } \\
<<\text { SKUPAI OBV. }\end{array}$}} \\
\hline & & 3.000 & & & \\
\hline SKUPAJ SRED. >> & 25.000 & 25.000 & & & \\
\hline
\end{tabular}


Bilanca stanja

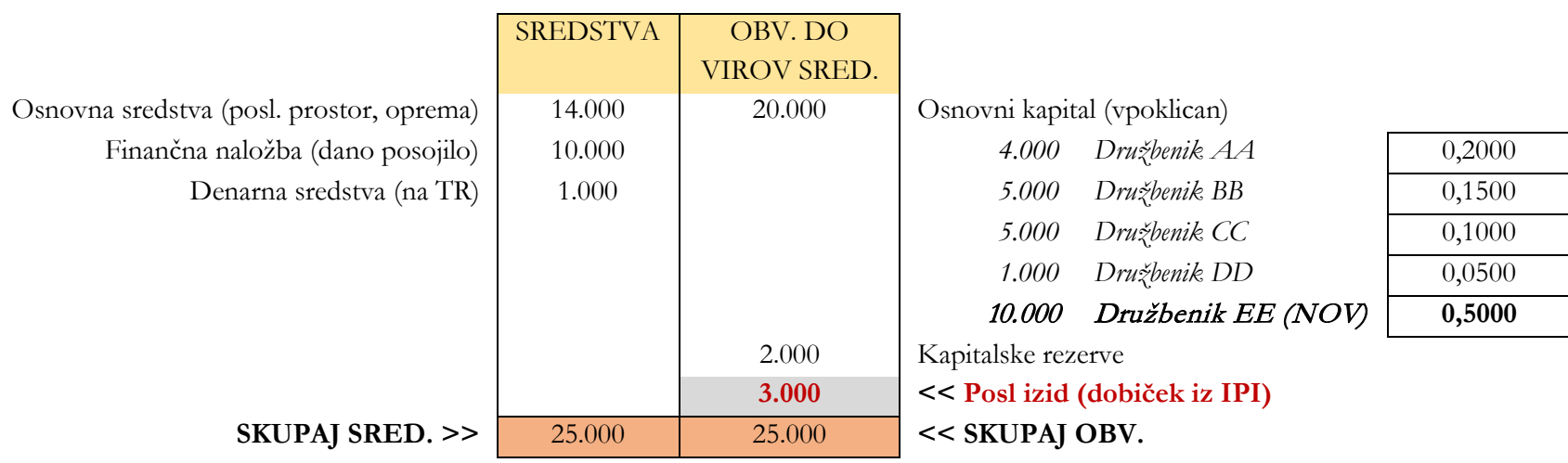

\begin{tabular}{|c|c|}
\hline $\begin{array}{c}\text { Izračun sprem. } \\
\text { posl. del.: }\end{array}$ & [Potr. plačilo] \\
\hline$-0,2000$ & $-5,000$ \\
\hline$-0,1500$ & $-3,750$ \\
\hline$-0,1000$ & $-2,500$ \\
\hline$-0,0500$ & $-1,250$ \\
\hline 0,5000 & \\
\hline 0 & $-12,500$ \\
\hline
\end{tabular}

Družbenik AA Družbenik BB Družbenik CC Družbenik DD Družbenik EE (NOV) SKUPAJ

\begin{tabular}{|c|c|c|c|}
\hline $\begin{array}{c}\text { "Star" OK } \\
\text { (vpok1.) }\end{array}$ & $\begin{array}{c}\text { Izračun sprem. } \\
\text { OK (vpok.): }\end{array}$ & $\begin{array}{c}\text { Nov OK } \\
\text { (vpokl.) }\end{array}$ & \\
\hline 8.000 & -4.000 & 4.000 & 0,4 \\
\hline 6.000 & -3.000 & 3.000 & 0,3 \\
\hline 4.000 & -2.000 & 2.000 & 0,2 \\
\hline 2.000 & -1.000 & 1.000 & 0,1 \\
\hline & 10.000 & 10.000 & \\
\hline 20.000 & 0 & 20.00 & \\
\hline
\end{tabular}




\section{LITERATURA}

Drnovšek G., Kosovne delnice in povečanje osnovnega kapitala, Pravna praksa, št. 12/2014, str. 6.

Drnovšek G., Ali ZGD-1 utesnjuje možnost financiranja s prednostnimi delnicami?, Podjetje in delo, št. 3-4/2013, str. 446.

Gajšek R., Združevanje in delitev poslovnih deležev, Podjetje in delo, št. 2/2010, str. 235.

Hieng R. et al., Ponazoritve knjiženj najpogostejših in bolj zapletenih poslovnih dogodkov, IKS: revija za računovodstvo in finance, letn. 35, št. 9/10, Zveza računovodskih in finančnih delavcev Slovenije, Ljubljana, 2008, str. 7-363.

Kocbek M. et al., Korporacijsko pravo, Pravni položaj gospodarskih subjektov, Druga, dopolnjena in predelana izdaja, GV Založba, Pravna fakulteta Univerze v Mariboru, Ljubljana, 2009.

Kocbek M. (redaktor), Veliki komentar Zakona o gospodarskih družbah, druga dopolnjena izdaja z novelami ZGD-1A in ZGD-1H, 1. knjiga, IUS SOFTWARE, GV Založba, Ljubljana, 2014.

Kocbek M. (redaktor), Veliki komentar Zakona o gospodarskih družbah, druga dopolnjena izdaja z novelami ZGD-1A in ZGD-1H, 2. knjiga, IUS SOFTWARE, GV Založba, Ljubljana, 2014.

Kocbek M. (redaktor), Veliki komentar Zakona o gospodarskih družbah, druga dopolnjena izdaja z novelami ZGD-1A in ZGD-1H, 3. knjiga, IUS SOFTWARE, GV Založba, Ljubljana, 2014.

Kocbek M., Izplačilo poslovnega deleža - kapitala izstopajočemu družbeniku v d.o.o., Pravna praksa 8/2004, str. 8.

Kocbek M., Razredi delnic in prednostne delnice, Podjetje in delo, št. 1/2015, str. 5.

Kontarščak K. A., Dolžnosti družbenikov in družbe v zvezi s spremembo lastništva poslovnih deležev d.o.o., Pravna praksa, št. 22/2008, str. 6.

Korošec B. et al., Osnove računovodstva, Univerza v Mariboru, Ekonomsko-poslovna fakulteta, Maribor, 2016.

Melavc D., Novak A., Controlling Praktikum, FOV Univerza v Mariboru, 2007.

Plavšak N., Vpis družbenika v sodni register tudi po uveljavitvi novele ZGD-1I nima oblikovalnih učinkov za pridobitev poslovnega deleža, Podjetje in delo, št. 2/2016, str. 211-232.

Podgorelec P., Ohranjanje osnovnega kapitala pri d.o.o., Podjetje in delo, št. 8/2006, str. 1669.

Prelič S. et al., Družba z omejeno odgovornostjo, GV Založba, Ljubljana, 2009.

Prostor J., Izstop družbenika iz d.o.o., Odvetnik 4/2013, str. 20. 


\title{
ŠTUDIJSKO GRADIVO PRI PREDMETU KORPORACIJSKO IN KONCERNSKO PRAVO: ZBIRKA VAJ
}

\author{
JERnEJA PROSTOR IN DANIEL ZDOLŠEK \\ Univerza v Mariboru, Pravna fakulteta, Maribor, Slovenija. \\ E-pošta: jerneja.prostor@um.si \\ Univerza v Mariboru, Ekonomsko-poslovna fakulteta, Maribor, Slovenija. \\ E-pošta: daniel.zdolsek@um.si
}

Povzetek Študijsko gradivo v obliki zbirke vaj je pripravljeno za izvedbo vaj v pedagoškem procesu pri predmetu Korporacijsko in koncernsko pravo na drugi stopnji bolonjskega študija prava na Pravni fakulteti Univerze $v$ Mariboru. Delo posega na področji pravnih in ekonomsko-poslovnih znanosti. Snov terja namreč dobro poznavanje zapletenih pravnih vprašanj, ki so neločljivo povezana $z$ računovodskimi operacijami. Študijsko gradivo je nujen pripomoček tistim, ki želijo kariero graditi kot gospodarski pravniki, seveda pa bo koristilo prav vsem za pripravo na izpit pri predmetu Korporacijsko in koncernsko pravo.

\author{
Ključne besede: \\ pravo \\ družb, \\ korporacijsko \\ pravo, \\ računovodstvo, \\ spremljanje \\ gospodarskih \\ kategorij, \\ poslovne \\ finance
}




\title{
STUDY MATERIAL FOR CORPORATE LAW AND LAW OF GROUPS OF COMPANIES:
} A Collection of EXERCises

\author{
JERneja PROSTOR \& DANIEL ZDOLŠEK \\ University of Maribor, Faculty of Law, Maribor, Slovenia. \\ E-mail: jerneja.prostor@um.si \\ University of Maribor, Faculty of Economics and Business, Maribor, Slovenia. \\ E-mail: daniel.zdolsek@um.si
}

Keywords: company law, corporate accounting, economic category monitoring, business finance

Abstract The study material is prepared for the implementation of exercises in the pedagogical process in the subject Corporate Law and Law of Groups of Companies at the second level of Bologna law studies at the Faculty of Law, University of Maribor. The work extends to the fields of legal and economic-business sciences. The content requires a good knowledge of complex legal issues that are inseparably linked to accounting transactions. Study material is a necessary tool for those who want to build a career as commercial lawyers, and will benefit everyone to prepare for the exam in the subject of Corporate Law and Law of Groups of Companies.

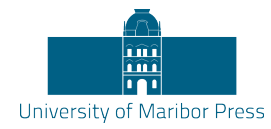




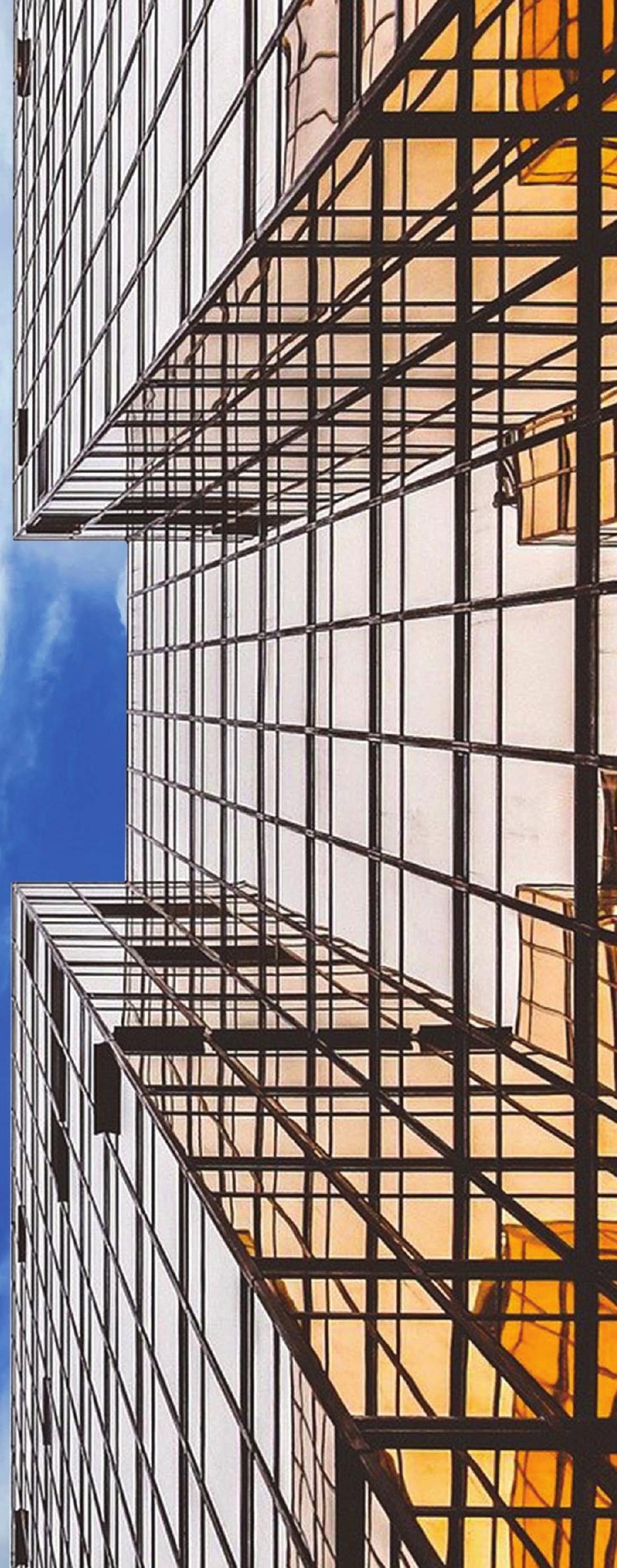


Pričujoče delo je učna

publikacija, ki je v prvi vrsti namenjena

študentom Pravne fakultete Univerze v Mariboru kot pomoč pri predmetu

Korporacijsko in koncernsko pravo. Gotovo pa bo nepogrešliiv pripomoček vsem, ki bi želeli oziroma že opravljajo delo pravnika v gospodarstvu, tako zaradi usvajanja kot tudi ponavlianja usvojenega znanja.

Gradivo posebno težo namenja institutom, ki so glede na učni načrt pri predmetu

Korporacijsko in koncernsko pravo najtežje razumliivi.

Predvsem gre za institute bilančnega prava, za kapitalska razmerja $v$ kapitalskih družbah (tudi v povezanih družbah) ter za pravo statusnih preoblikovanj.

iz recenzije prof. dr. Marijan Kocbek

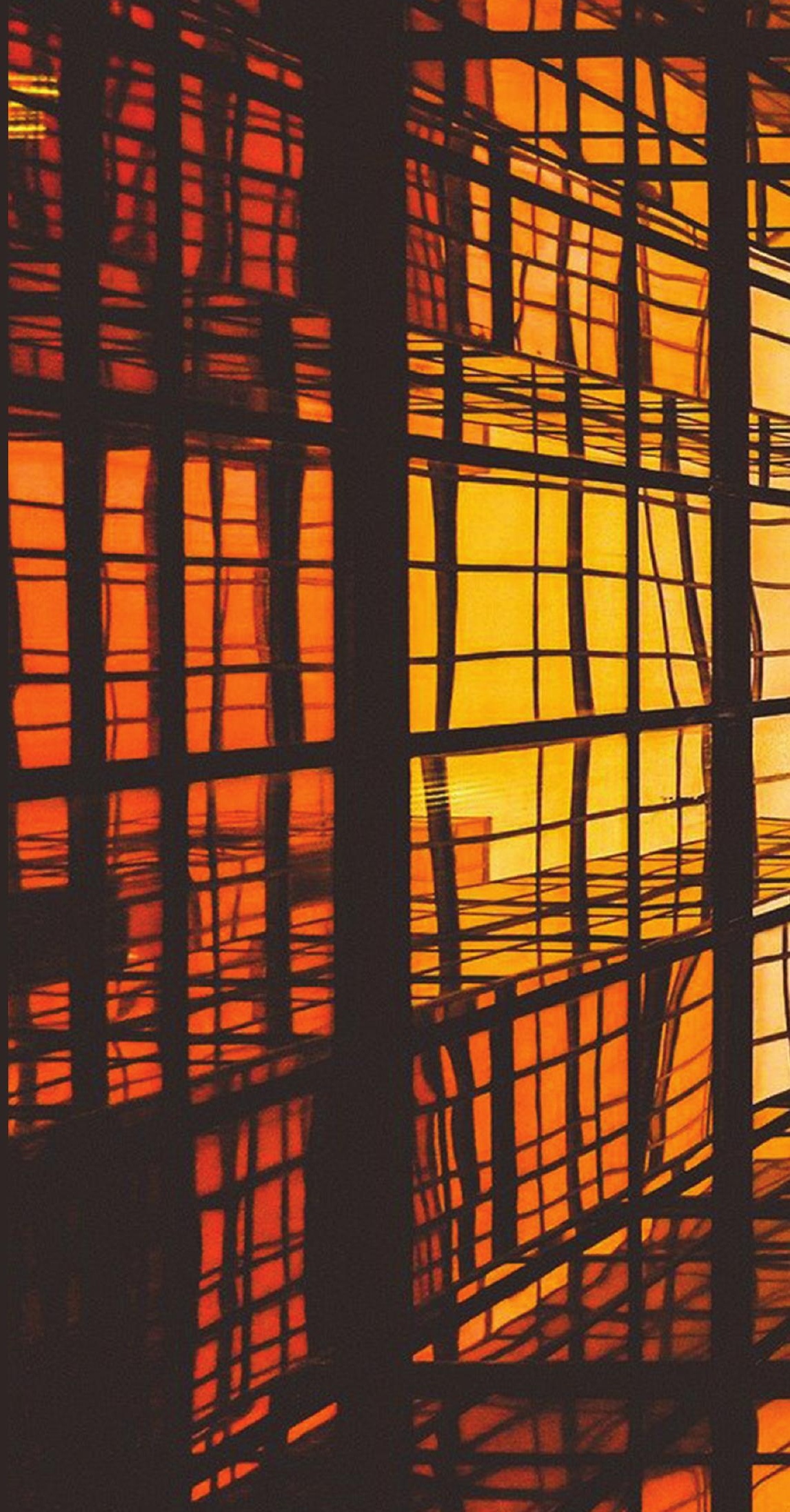

